Júlia Beatriz Duarte Alves de Camargo

Efeitos biológicos da contaminação sobre bivalves filtradores de regiões do litoral de São Paulo, com ênfase na Baixada Santista

Dissertação apresentada ao Instituto Oceanográfico da Universidade de São Paulo, como parte dos requisitos para obtenção do título de Mestre em Ciências, Programa de Oceanografia, área de Oceanografia Biológica.

Orientadora:

Profa. Dra. Eduinetty Ceci Pereira Moreira de Sousa

São Paulo

2018 
Camargo, Júlia Beatriz Duarte Alves de

Efeitos biológicos da contaminação sobre bivalves filtradores de regiões do litoral de São Paulo, com ênfase na Baixada Santista / Júlia Beatriz Duarte Alves de Camargo - São Paulo, SP: IOUSP, 2018.

$145 \mathrm{p}$.

Dissertação (Mestrado - Oceanografia, com concentração em Oceanografia Biológica) - Universidade de São Paulo, Instituto Oceanográfico.

Orientadora: Profa. Dra. Eduinetty Ceci Pereira Moreira de Sousa.
1. Ecotoxicologia marinha
2. Monitoramento ambiental

CDD 577.51

Palavras-chave: qualidade ambiental; monitoramento; moluscos; biomarcadores; metais; vermelho neutro. 
Universidade de São Paulo

Instituto Oceanográfico

\title{
Efeitos biológicos da contaminação sobre bivalves filtradores de regiões do litoral de São Paulo, com ênfase na Baixada Santista
}

\author{
Júlia Beatriz Duarte Alves de Camargo
}

\section{VERSÃO CORRIGIDA}

Dissertação apresentada ao Instituto Oceanográfico da Universidade de São Paulo, como parte dos requisitos para obtenção do título de Mestre em Ciências, Programa de Oceanografia, área de Oceanografia Biológica.

Julgada em

Profa. Dra. Eduinetty Ceci Pereira Moreira de Sousa

Conceito

Prof. Dr. Rodrigo Brasil Choueri

Conceito

Prof. Dr. Denis Moledo de Souza Abessa

Conceito 
Los meus avós, Koana, Lindinalwa e Maximino.

Losmeus pais, Gintia e Ronaldo.

Lo meu querido irmão, Diquinho. 


\section{Agradecimentos}

Aos meus pais, pela vida e pela valorização à vida. Pela força, pela lucidez e pelo amor. Vocês são as pessoas mais importantes para mim, eu os admiro demais e, sem vocês, eu não seria nada. E ao Diguinho que, no seu curto tempo conosco, nos ensinou muito com seu bom-humor, força, perseverança, vivacidade e invencibilidade espiritual. O tempo passa, mas você está eternamente dentro de nós.

À minha família, que a gente não escolhe, mas, se eu pudesse escolher, teria exatamente a mesma. Obrigada pelos valores, pelas oportunidades, pelos laços e pelo suporte. Sem vocês, eu não me sustentaria.

À Marina, amiga, irmã, que está ao meu lado sempre, nos melhores e nos piores momentos. Pela amizade inabalável e inestimável. Pelas conversas, conselhos, compartilhamentos, risadas, festas, viagens... São tantas coisas! Obrigada. Te amo!

Ao Heitor que, apesar dos pesares, fez parte da minha vida por um bom tempo e contribuiu para a construção dos meus pensamentos e meus valores.

À Profa. Ceci por ter proporcionado a oportunidade do Mestrado e pela orientação.

À Dra. Marília primeiramente por permitir que eu pudesse aproveitar seu material para realizar este projeto, pela paciência para me ensinar os procedimentos e análises, e pela colaboração e realização das análises de bioacumulação.

À Márcia pela ajuda nas análises, pelos ensinamentos e conversas, e pela paciência.

Ao Prof. Denis, que muito contribuiu para minha formação como pesquisadora desde a iniciação científica e me colocou em contato com a Ceci, tornando possível o estabelecimento desta parceria e a elaboração deste projeto.

À Dra. Luciane Maranho e à Dra. Paloma Gusso-Choueri pela ajuda com as análises de biomarcadores, pelas explicações e pelo apoio, sem os quais este trabalho não seria o mesmo.

Aos colegas do Lecotox, Isa, Claudio, Maryta, Alice, Cris, pelas conversas, risadas e cafezinhos, que deixam o dia-a-dia no laboratório mais divertidos! 
Aos colegas do NEPEA, Carol, Gua, Gabi, Lucas, Fefo, Lu e Paloma, pela ajuda nas análises laboratoriais, mas, mais importante, pelas risadas e momentos de descontração, e por me fazer sentir parte do grupo.

Ao Instituto Oceanográfico da USP, pela oportunidade, e aos funcionários da Secretaria de Pós-Graduação, Ana Paula, Daniel e Letícia, pela ajuda nos processos burocráticos.

Aos pescadores artesanais Bill, Nildo, Zé Luís e Jackson e à Cooperostra pela ajuda na coleta e fornecimento dos organismos utilizados no estudo.

À Fundação Florestal e ao Parque Estadual Xixová-Japuí pela concessão da permissão da coleta dentro da área do Parque. Agradeço especialmente ao ex-gestor Paulo Menna pela disposição e pelo apoio nas coletas dos organismos. Agradeço também à Fortaleza de Itaipu (e ao Sargento Kardec) e ao Clube de Pesca de Santos pelo apoio às coletas.

Aos membros da banca por aceitarem o convite e pelas sugestões e comentários realizados.

Por fim, mas não menos importante, à CAPES pelo auxílio financeiro ao longo do Mestrado, sem o qual teria sido impossível desenvolver a pesquisa aqui apresentada. 
"A onda do mar leva,

A onda do mar traz,

Quem vem pra beira da praia, meu bem

Não volta nunca mais"

(Dorival Caymmi) 


\section{Resumo}

Este trabalho avaliou a bioacumulação de metais e as respostas biológicas em mexilhões Perna perna coletados na Praia da Cocanha, Ilha das Palmas e Ponta de Itaipu, e ostras Crassostrea brasiliana coletadas nos Estuários de Cananéia, Santos e Bertioga em diferentes estações do ano. Foram realizadas duas campanhas: 2008/09 e 2016/17. A Cocanha apresentou elevados níveis de metais, indução de EROD e DBF e efeitos peroxidativos e genotóxicos. Em Palmas houve ativação de EROD, DBF, GST e GSH. Itaipu evidenciou bioacumulação de metais, ativação de GST e GSH e danos no DNA. Em Cananéia houve bioacumulação de As e Cr, respostas das fases I e II e efeitos peroxidativos. Santos exibiu piores condições fisiológicas, com alterações bioquímicas em todas as estações do ano. Bertioga piorou em 2016/17 em relação a 2008/09, evidenciado por maior bioacumulação de metais e respostas de biotransformação e antioxidantes e efeitos neurotóxicos. Os dados evidenciam fontes de contaminação diferentes para cada local e variação de acordo com o período do ano em função de diversos fatores (e.g. pluviosidade, reprodução, turismo). Os locais escolhidos como referência demonstraram estar sob influência de fontes pontuais de contaminação. Deve-se considerar que Itaipu e Cananéia integram unidades de conservação.

Palavras-chave: qualidade ambiental, monitoramento, moluscos, biomarcadores, metais, vermelho neutro. 


\begin{abstract}
The present study assessed the bioaccumulation of metals and the biological responses in mussels Perna perna from Cocanha Brach, Palmas Island and Ponta de Itaipu, and oysters Crassostrea brasiliana from the estuaries of Cananéia, Santos and Bertioga in different seasons. Two campaigns were carried out: 2008/09 and 2016/17. Cocanha showed high levels of metals, induction of EROD and DBF and peroxidative and genotoxic damages. Palmas exhibited induction of EROD, DBF, GST and GSH. Itaipu exhibited bioaccumulation of metals, activation of GST and GSH and DNA damage. Cananéia showed bioaccumulation of As and $\mathrm{Cr}$, phases I and II responses and peroxidative damage. Santos exhibited the worst physiological conditions, with biochemical alterations in all seasons. Bertioga conditions worsened in 2016/17 compared to 2008/09, evidenced by the higher content of metals and biotransformation and antioxidant responses and neurotoxic damage. These data show different sources of contamination for each site and variation in accordance with the time of the year due to several factors (e.g. rainfall, reproduction, tourism). The sites chosen as reference may be influenced by point sources of contamination. It should be considered that Itaipu and Cananéia are within protected areas.
\end{abstract}

Keywords: environmental quality, monitoring, mollusks, biomarkers, metals, neutral red. 


\section{Lista de figuras}

Figura 1. Diagrama representando as diferentes fases do metabolismo de contaminantes dentro dos organismos (retângulos azuis), seus produtos (retângulos azuis arredondados) e os biomarcadores bioquímicos (retângulos amarelos) e fisiológico (retângulo verde) relacionados a cada uma delas. (CYP) família de citocromos; (EROD) etoxiresorufina O-desetilase; (DBF) dibenzilfluoresceína; (GST) glutationa S-transferase; (ROS) espécies reativas de oxigênio; (GPx) glutationa peroxidase; (GSH) tripeptídeo glutationa; (LPO) peroxidação lipídica; (DNA) danos em DNA; (ChE) colinesterases; (LMS) estabilidade de membrana lisossômica. Adaptado de Maranho (2014).

Figura 2. Mapa da área de estudo indicando a localização dos pontos de coleta de mexilhões $P$. perna (A) e ostras C. brasiliana (O) na Região Metropolitana da Baixada Santista (RMBS), litoral centro; na Praia da Cocanha, litoral norte; e em Cananéia, litoral sul do estado de São Paulo. Marcadores verdes indicam áreas consideradas referência de qualidade, enquanto marcadores vermelhos indicam áreas possivelmente sujeitas à contaminação.

Figura 3. Visão externa (A) e interna (B) do mexilhão Perna perna; e visão externa (C) e interna (D) da ostra Crassostrea brasiliana (Fotos: Júlia Camargo).

Figura 4. Tanque de água do mar do Laboratório de Ecotoxicologia Marinha e Microfitobentos (LEcotox), onde os organismos coletados (mexilhões e ostras) foram aclimatados por pelo menos um dia antes do preparo das amostras para as análises (Foto: Júlia Camargo).

Figura 5. Anatomia interna do mexilhão P. perna (vista do lado esquerdo) após a remoção de parte do manto e esquema demonstrando para quais análises cada parte do organismo foi utilizada. O esquema também é representativo para as ostras C. brasiliana. (alod) lamela ascendente da demibrânquia externa; (arm) músculo anterior retrator do bisso; (by) bisso; (ex) sifão exalante; (f) pé; (frm) músculo retrator do pé; (hr) região do coração; (in) sifão inalante; (lid) resto da demibrânquia interna esquerda; (lod) resto da demibrânquia externa esquerda; (lolp) palpo esquerdo externo; (m) manto; (mrm) músculo mediano retrator do bisso; (pam) músculo adutor posterior; (prm) músculo posterior retrator do bisso; (rid) demibrânquia interna direita; (rilp) palpo labial interno direito; (rod) demibrânquia externa direita; (rolp) palpo labial externo direito; (u) umbo; (FH) fração homogeneizada; (S15) fração sobrenadante após centrifugação a 15.000g; (LPO) peroxidação lipídica; (DNA) danos em DNA; (PTh) conteúdo de proteína total em FH); (EROD) etoxiresorufina O-desetilase; (DBF) dibenzilfluoresceína; (GST) glutationa Stransferase; (GSH) tripeptídeo glutationa; (ChE) colinesterases; (PTc) conteúdo de proteína toal em S15; (NRRT) tempo de retenção do vermelho neutro. Adaptado de Narchi \& Galvão-Bueno (1997).

Figura 6. Mexilhões separados por classe de tamanho, sendo 30 pequenos, 30 médios e 30 grandes (nesta ordem). No canto superior direito, o paquímetro utilizado para realizar a biometria. A separação das ostras foi feita da mesma maneira (Foto: Júlia Camargo).

Figura 7. Trituração (A), pesagem (B) e acondicionamento em potes plásticos (C) das amostras de tecido mole dos organismos analisados (Fotos A e B: Marília G.M.C. Semmler; Foto C: Júlia Camargo)......... 17

Figura 8. Liofilização das amostras no liofilizador Thermo Electron Corporation, modelo ModulyoD115, no Laboratório de Análises por Ativação Neutrônica (LAN) (A) e peneiração em malha de 80 mesh das amostras liofilizadas (B) (Foto A: Marília G.M.C. Semmler; Foto B: Júlia Camargo). 
Figura 9. Leitor de microplaca por multidetecção Synergy ${ }^{\mathrm{TM}}$ HT da BioTek ${ }^{\circledR}$, onde foram realizadas as leituras para análise dos biomarcadores bioquímicos (Foto: Júlia Camargo).

Figura 10. Brânquias do mexilhão Perna perna (esquerda) e da ostra Crassostrea brasiliana (direita), dissecadas para análise dos biomarcadores bioquímicos (Fotos: Júlia Camargo). 21

Figura 11. Armazenamento das amostras em ultrafreezer a $-80^{\circ} \mathrm{C}$ (Foto: Júlia Camargo). 21

Figura 12. Representação do processo de homogeneização, centrifugação e separação das alíquotas para análise de cada um dos biomarcadores bioquímicos. (FH) fração homogeneizada; (S15) fração sobrenadante; (LPO) peroxidação lipídica; (DNA) danos em DNA; (PTh) conteúdo de proteína total de FH; (EROD) etoxiresorufina O-desetilase; (DBF) dibenzilfluoresceína; (GST) glutationa S-transferase; (ROS) espécies reativas de oxigênio; (GSH) tripeptídeo glutationa; (ChE) colinesterases; (PTc) conteúdo de proteína total de $\mathrm{S} 15$.

Figura 13. Músculos adutores posteriores (seta vermelha) do mexilhão Perna perna (esquerda) e da ostra Crassostrea brasiliana (direita), através do qual a agulha da seringa hipodérmica é inserida para extração da hemolinfa (Fotos: Júlia Camargo).

Figura 14. Aplicação da solução de células sanguíneas às lâminas de microscópio dispostas no interior de uma câmara úmida à prova de luz (Foto: Marília G.M.C. Semmler). 28

Figura 15. Hemócitos tratados com corante vermelho neutro observados sob microscópio óptico (400x). As setas pretas indicam exemplos de alguns dos critérios analisados (Foto: Júlia Camargo). 29

Figura 16. Relação comprimento-altura das conchas de mexilhões $P$. perna (A, C, E) e ostras $C$. brasiliana (B, D, F) utilizados para análises de bioacumulação de metais (A, B), biomarcadores bioquímicos (C, D) e biomarcador físiológico (E, F). Pontos de coleta: Cocanha e Cananéia (preto); Palmas e Santos (cinza claro); Itaipu e Bertioga (cinza escuro). Estações do ano: primavera/2008 verão/2009 (ם); inverno/2009 (०); primavera/2016 (A); outono/2017 (O 32

Figura 17. Concentrações de metais $\left(\mu \mathrm{g} \mathrm{g}^{-1}\right)$ nos tecidos de mexilhões $P$. perna (peso úmido) coletados durante a primavera/2008, o verão/2009 e o inverno/2009, como parte do trabalho de pós-doutorado da Dra. Marília G. M. C. Semmler. Incertezas são incertezas expandidas k=2. Asteriscos indicam diferença significativa em relação à Cocanha $(\mathrm{p}<0,05)$. 35

Figura 18. Concentrações de metais $\left(\mu \mathrm{g} \mathrm{g}^{-1}\right)$ nos tecidos de ostras C. brasiliana (peso úmido) coletadas durante a primavera/2008, o verão/2009 e o inverno/2009, como parte do trabalho de pós-doutorado da Dra. Marília G. M. C. Semmler. Incertezas são incertezas expandidas k=2. Asteriscos indicam diferença significativa em relação a Cananéia $(\mathrm{p}<0,05) \ldots$

Figura 19. Respostas bioquímicas de EROD, DBF, GST, GSH, DNA, LPO e ChE (média \pm DP) analisadas em brânquias de mexilhões P. perna coletados durante a primavera/2008, o verão/2009 e o inverno/2009. Asteriscos indicam diferença significativa em relação à Cocanha $(\mathrm{p}<0,05)$. . .38

Figura 20. Respostas bioquímicas de EROD, DBF, GST, GSH, DNA, LPO e ChE (média \pm DP) analisadas em brânquias de ostras C. brasiliana coletadas durante a primavera/2008, o verão/2009 e o inverno/2009. Asteriscos indicam diferença significativa em relação a Cananéia $(p<0,05)$. 39 
Figura 21. Ordenação dos resultados (loadings e scores) da análise de componentes principais baseada nos dados de bioacumulação de metais (vermelho), biomarcadores bioquímicos e físiológico (azul) obtidos para mexilhões $P$. perna coletados durante a primavera/2008, o verão/2009 e o inverno/2009.... 43

Figura 22. Ordenação dos resultados (loadings e scores) da análise de componentes principais baseada nos dados de bioacumulação de metais (vermelho), biomarcadores bioquímicos e físiológico (azul) obtidos para ostras C. brasiliana coletadas durante a primavera/2008, o verão/2009 e o inverno/2009.... 43

Figura 23. Concentrações de metais $\left(\mu \mathrm{g} \mathrm{g}^{-1}\right)$ nos tecidos de mexilhões $P$. perna (peso úmido) coletados durante a primavera/2016 e o outono/2017. Incertezas são incertezas expandidas $\mathrm{k}=2$. Asteriscos indicam diferença significativa em relação à Cocanha $(\mathrm{p}<0,05)$.

Figura 24. Concentrações de metais $\left(\mu \mathrm{g} \mathrm{g}^{-1}\right)$ nos tecidos de ostras C. brasiliana (peso úmido) coletadas durante a primavera/2016 e o outono/2017. Incertezas são incertezas expandidas $\mathrm{k}=2$. Asteriscos indicam diferença significativa em relação a Cananéia $(\mathrm{p}<0,05)$.

Figura 25. Respostas bioquímicas de EROD, DBF, GST, GSH, LPO, DNA e ChE (média \pm DP) analisadas em brânquias de mexilhões $P$. perna coletados durante a primavera/2016 e o outono/2017. Asteriscos indicam diferença significativa em relação à Cocanha $(\mathrm{p}<0,05)$.

Figura 26. Respostas bioquímicas de EROD, DBF, GST, GSH, LPO, DNA e ChE (média \pm DP) analisadas em brânquias de ostras C. brasiliana coletadas durante a primavera/2016 e o outono/2017. Asteriscos indicam diferença significativa em relação a Cananéia $(\mathrm{p}<0,05)$.

Figura 27. Tempos de retenção do corante vermelho neutro (média \pm DP) observados para mexilhões $P$. perna coletados na primavera/2016 e no outono/2017. Asteriscos representam diferença significativa em relação à Cocanha $(\mathrm{p}<0,05)$. A linha vermelha pontilhada representa environmental assessment criteria (= $30 \mathrm{~min})$ e a linha pontilhada azul representa background assessment criteria (=60 min), de acordo com Ortega et al. (2018).

Figura 28. Tempos de retenção do corante vermelho neutro (média \pm DP) observados para ostras $C$. brasiliana coletadas na primavera/2016 e no outono/2017. Asteriscos representam diferença significativa em relação a Cananéia $(\mathrm{p}<0,05)$. A linha vermelha pontilhada representa environmental assessment criteria (= $30 \mathrm{~min})$ e a linha pontilhada azul representa background assessment criteria $(=60 \mathrm{~min})$, de acordo com Ortega et al. (2018).

Figura 29. Ordenação dos resultados (loadings e scores) da análise de componentes principais baseada nos dados de bioacumulação de metais (vermelho), biomarcadores bioquímicos e fisiológico (azul) obtidos para mexilhões $P$. perna coletados durante a primavera/2016 e outono/2017.

Figura 30. Ordenação dos resultados (loadings e scores) da análise de componentes principais baseada nos dados de bioacumulação de metais (vermelho), biomarcadores bioquímicos e físiológico (azul) obtidos para ostras C. brasiliana coletadas durante a primavera/2016 e o outono/2017. .. 57

Figura 31. Critérios BAC e EAC para a estabilidade de membrana lisossomal medida como tempo de retenção do vermelho neutro (Ortega et al., 2018). Adaptado de Martínez-Gómez et al. (2015). 


\section{Lista de tabelas}

Tabela 1. Classificação taxonômica do mexilhão Perna perna e da ostra Crassostrea brasiliana, ambos organismos-modelo utilizados neste estudo

Tabela 2. Resumo dos pontos onde foram coletados os mexilhões P. perna e as ostras C. brasiliana. Asteriscos indicam as áreas consideradas referência de qualidade para cada organismo.

Tabela 3. Critérios analisados na observação das lâminas com hemócitos tratados com vermelho neutro. Modificado de Pereira (2008).

Tabela 4. Comprimento $(\mathrm{cm})$ e altura $(\mathrm{cm})$ médios, mínimos e máximos das conchas dos mexilhões $P$. perna e das ostras C. brasiliana utilizados nas análises de bioacumulação de metais, biomarcadores bioquímicos e biomarcador fisiológico.

Tabela 5. Concentrações de metais $\left(\mu \mathrm{g} \mathrm{g}^{-1}\right)$ nos tecidos de mexilhões $P$. perna (peso úmido) coletados durante a primavera/2008, o verão/2009 e o inverno/2009, como parte do trabalho de pós-doutorado da Dra. Marília G. M. C. Semmler. Incertezas são incertezas expandidas k=2. Asteriscos indicam diferença significativa em relação à Cocanha $(\mathrm{p}<0,05)$. Retirado de Catharino et al. (2012).

Tabela 6. Concentrações de metais $\left(\mu \mathrm{g} \mathrm{g}^{-1}\right)$ nos tecidos de ostras C. brasiliana (peso úmido) coletados durante a primavera/2008, o verão/2009 e o inverno/2009, como parte do trabalho de pós-doutorado da Dra. Marília G. M. C. Semmler. Incertezas são incertezas expandidas k=2. Asteriscos indicam diferença significativa em relação à Cananéia $(\mathrm{p}<0,05)$. Retirado de Catharino et al. (2015). 34

Tabela 7. Respostas bioquímicas de EROD, DBF, GST, GSH, DNA, LPO e ChE (média \pm DP) analisadas em brânquias de mexilhões P. perna coletados durante a primavera/2008, o verão/2009 e o inverno/2009. Asteriscos indicam diferença significativa em relação à Cocanha $(p<0,05)$.

Tabela 8. Respostas bioquímicas de EROD, DBF, GST, GSH, DNA, LPO e ChE (média \pm DP) analisadas em brânquias de ostras C. brasiliana coletadas durante a primavera/2008, o verão/2009 e o inverno/2009. Asteriscos indicam diferença significativa em relação a Cananéia $(p<0,05)$.

Tabela 9. Concentrações de metais $\left(\mu \mathrm{g} \mathrm{g}^{-1}\right)$ nos tecidos de mexilhões $P$. perna (peso úmido) coletados durante a primavera/2016 e o outono/2017. Incertezas são incertezas expandidas $\mathrm{k}=2$. Asteriscos indicam diferença significativa em relação à Cocanha $(p<0,05)$.

Tabela 10. Concentrações de metais $\left(\mu \mathrm{g} \mathrm{g}^{-1}\right)$ nos tecidos de ostras C. brasiliana (peso úmido) coletadas durante a primavera/2016 e o outono/2017. Incertezas são incertezas expandidas $\mathrm{k}=2$. Asteriscos indicam diferença significativa em relação a Cananéia $(p<0,05)$.

Tabela 11. Respostas bioquímicas de EROD, DBF, GST, GSH, LPO, DNA e ChE (média \pm DP) analisadas em brânquias de mexilhões $P$. perna coletados durante a primavera/2016 e o outono/2017. Asteriscos indicam diferença significativa em relação à Cocanha $(\mathrm{p}<0,05)$.

Tabela 12. Respostas bioquímicas de EROD, DBF, GST, GSH, LPO, DNA e ChE (média \pm DP) analisadas em brânquias de ostras C. brasiliana coletadas durante a primavera/2016 e o outono/2017. Asteriscos indicam diferença significativa em relação a Cananéia $(p<0,05)$. 
Tabela 13. Tempos de retenção do corante vermelho neutro (média $\pm \mathrm{DP}$ ) observados para mexilhões $P$. perna e ostras C. brasiliana coletados durante a primavera/2016 e o outono/2017. Asteriscos indicam diferença significativa em relação à Cocanha e a Cananéia, respectivamente $(\mathrm{p}<0,05)$. 54

Tabela 14. Comprimento $(\mathrm{cm})$ e altura $(\mathrm{cm})$ das conchas de cada mexilhão $P$. perna e cada ostra $C$. brasiliana utilizados nas análises de bioacumulação de metais.

Tabela 15. Comprimento $(\mathrm{cm})$ e altura $(\mathrm{cm})$ das conchas de cada mexilhão $P$. perna e cada ostra $C$. brasiliana utilizados nas análises de biomarcadores bioquímicos

Tabela 16. Comprimento $(\mathrm{cm})$ e altura $(\mathrm{cm})$ das conchas de cada mexilhão $P$. perna e cada ostra $C$. brasiliana utilizados na análise do biomarcador fisiológico.

Tabela 17. Respostas bioquímicas de EROD, DBF, GST, GSH, LPO, DNA e ChE medidas em cada amostra de brânquia de mexilhões $P$. perna coletados durante a primavera/2008. 104

Tabela 18. Respostas bioquímicas de EROD, DBF, GST, GSH, LPO, DNA e ChE medidas em cada amostra de brânquia de mexilhões $P$. perna coletados durante o verão/2009. 105

Tabela 19. Respostas bioquímicas de EROD, DBF, GST, GSH, LPO, DNA e ChE medidas em cada amostra de brânquia de mexilhões $P$. perna coletados durante o inverno/2009.

Tabela 20. Respostas bioquímicas de EROD, DBF, GST, GSH, LPO, DNA e ChE medidas para cada amostra de brânquia de mexilhões $P$. perna coletados durante a primavera/2016.

Tabela 21. Respostas bioquímicas de EROD, DBF, GST, GSH LPO, DNA e ChE medidas para cada amostra de brânquia de mexilhões $P$. perna coletados durante o outono/2017. 110

Tabela 22. Respostas bioquímicas de EROD, DBF, GST, GSH, LPO, DNA e ChE medidas em cada amostra de brânquia de ostras C. brasiliana coletadas durante a primavera/2008.

Tabela 23. Respostas bioquímicas de EROD, DBF, GST, GSH, LPO, DNA e ChE medidas em cada amostra de brânquia de ostras C. brasiliana coletadas durante o verão/2009. 113

Tabela 24. Respostas bioquímicas de EROD, DBF, GST, GSH, LPO, DNA e ChE medidas em cada amostra de brânquia de ostras C. brasiliana coletadas durante o inverno/2009.

Tabela 25. Respostas bioquímicas de EROD, DBF, GST, GSH, LPO, DNA e ChE medidas em cada amostra de brânquia das ostras $C$. brasiliana coletadas durante a primavera/2016.

Tabela 26. Respostas bioquímicas de EROD, DBF, GST, GSH, LPO, DNA e ChE medidas em cada amostra de brânquia de ostras C. brasiliana coletadas durante o outono/2017.

Tabela 27. Tempos de retenção do corante vermelho neutro (minutos) observados para cada mexilhão $P$. perna e cada ostra C. brasiliana analisados.

Tabela 28. Matriz de dados referentes aos mexilhões $P$. perna coletados durante a primavera/2008, o verão/2009 e o inverno/2009, empregados na análise de componentes principais (PCA). 122

Tabela 29. Matriz de dados referentes às ostras C. brasiliana coletadas durante a primavera/2008, o verão/2009 e o inverno/2009, empregados na análise de componentes principais (PCA).

Tabela 30. Matriz de dados referentes aos mexilhões $P$. perna coletados durante a primavera/2016 e o outono/2017, empregados na análise de componentes principais (PCA) 
Tabela 31. Matriz de dados referentes às ostras C. brasiliana coletadas durante a primavera/2016 e o outono/2017, empregados na análise de componentes principais (PCA)

Tabela 32. Autovalores (Eigenvalues) para cada componente (Eigenvectors) e loadings para cada variável, gerados pela PCA a partir dos dados referentes aos mexilhões $P$. perna coletados durante a primavera/2008, o verão/2009 e o inverno/2009. Valores destacados quando $\mid$ loadings $\mid \geq 0,50$.

Tabela 33. Scores para cada ponto de coleta, gerados pela PCA a partir dos dados referentes aos mexilhões $P$. perna coletados durante a primavera/2008, o verão/2009 e o inverno/2009.

Tabela 34. Autovalores (Eigenvalues) para cada componente (Eigenvectors) e loadings para cada variável gerados pela PCA a partir dos dados referentes às ostras C. brasiliana coletadas durante a primavera/2008, o verão/2009 e o inverno/2009. Valores destacados quando $\mid$ loadings $\mid \geq 0,50$.

Tabela 35. Scores para cada ponto de coleta, gerados pela PCA a partir dos dados referentes às ostras $C$. brasiliana coletadas durante a primavera/2008, o verão/2009 e o inverno/2009.

Tabela 36. Autovalores (Eigenvalues) para cada componente (Eigenvectors) e loadings para cada variável, gerados pela PCA a partir dos dados referentes aos mexilhões $P$. perna coletados durante a primavera/2016 e outono/2017. Valores destacados quando $\mid$ loadings $\mid \geq 0,50$.

Tabela 37. Scores para cada ponto de coleta, gerados pela PCA a partir dos dados referentes aos mexilhões $P$. perna coletados durante a primavera/2016 e o outono/2017

Tabela 38. Autovalores (Eigenvalues) para cada componente (Eigenvectors) e loadings para cada variável, gerados pela PCA a partir dos dados referentes às ostras C. brasiliana coletadas durante a primavera/2016 e outono/2017. Valores destacados quando $\mid$ loadings $\mid \geq 0,50$. 125

Tabela 39. Scores para cada ponto de coleta, gerados pela PCA a partir dos dados referentes às ostras $C$. brasiliana coletadas durante a primavera/2016 e outono/2017. 


\section{Lista de abreviaturas e siglas}

$\lambda_{\text {emissão }}, \lambda_{\text {em }} \quad$ Comprimento de onda de emissão

$\lambda_{\text {excitação }} \boldsymbol{\lambda}_{\text {ex }} \quad$ Comprimento de onda de excitação

AAS Espectrometria de absorção atômica

Alt.

Altura da concha

ANOVA

Análise de variância

As

Arsênio

BAC

Critério basal de resposta (background assessment criteria)

Ber

Bertioga

BSA

Albumina bovina sérica (bovine serum albumin)

buffer

Solução tampão de homogeneização

$\mathrm{CaCl}_{2}$

Cloreto de cálcio

Can

Cananéia

CAT

Catalase

Cd

Cádmio

CDNB

1-cloro-2,4-dinitrobenzeno

ChE

Colinesterases

Co

Cobalto

Coc

Cocanha

Comp.

Cr

Comprimento da concha

Cromo

CV AAS

CYP

Espectrometria de absorção atômica com geração de vapor frio

CYP450

Família de citocromos

DBF

Citocromo P450

DMSO

Dibenzilfluoresceína

DNA

Dimetilsulfóxido

DP

Danos em DNA (strand breaks)

DSS

Desvio padrão

DTNB

Dodecil sulfato de sódio

DTT

Ácido 5,5'-ditiobis-2-nitrobenzoico

e.g.

Ditiotreitol

EAC

Por exemplo (exempli gratia)

EDTA

Critério ambiental de resposta (environmental assessment criteria)

EROD

Àcido etilenodiamino tetra-acético

ET AAS

Etoxiresorufina O-desetilase

\section{Fe}

Espectrometria de absorção atômica com atomização eletrotérmica

FH Ferro

GPx

Fração homogeneizada, homogenato

GR

Glutationa peroxidase

GSH Glutationa redutase

Tióis reduzidos não-proteicos, tripeptídeo reduzido glutationa 


\begin{tabular}{|c|c|}
\hline GSSG & Tripeptídeo oxidado glutationa \\
\hline GST & Glutationa S-transferase \\
\hline HCl & Ácido clorídrico \\
\hline Hg & Mercúrio \\
\hline $\mathrm{HNO}_{3}$ & Ácido nítrico \\
\hline HPAs & Hidrocarbonetos policíclicos aromáticos \\
\hline i.e. & Isto é, ou seja (id est) \\
\hline IB-CLP/UNESP & Instituto de Biociências da Universidade Estadual Paulista "Júlio de Mesquita Filho" \\
\hline ICES & International Council for the Exploration of the Sea \\
\hline INAA & Ativação com nêutrons instrumental \\
\hline Inv/09, I09 & Inverno de 2009 \\
\hline IOUSP & Instituto Oceanográfico da USP \\
\hline IPEN/CNEN-SP & Instituto de Pesquisas Energéticas e Nucleares \\
\hline Ita & Itaipu \\
\hline JAMP & Joint Assessment Monitoring Programme \\
\hline KCl & Cloreto de potássio \\
\hline LABs & Alquilbenzenos lineares \\
\hline LAN & Laboratório de Análise por Ativação Neutrônica \\
\hline LEcotox & Laboratório de Ecotoxicologia Marinha e Microfitobentos \\
\hline LMS & Estabilidade de membrana lisossômica \\
\hline LPO & Peroxidação lipídica \\
\hline MEDPOL & Mediterranean Pollution Programme \\
\hline MFO & Sistema de oxidases de função mista (mixed-function oxidases) \\
\hline $\mathrm{MgSO}_{4}$ & Sulfato de magnésio \\
\hline $\mathrm{NaCl}$ & Cloreto de sódio \\
\hline NADPH & Fosfato de dinucleotídeo nicotinamida-adenina \\
\hline $\mathrm{NaOH}$ & Hidróxido de sódio \\
\hline NEPEA & Núcleo de Estudos em Poluição e Ecotoxicologia Aquática \\
\hline $\mathbf{N R}$ & Corante vermelho neutro \\
\hline NRRT & Tempo de retenção do corante vermelho neutro (neutral red retention time) \\
\hline OECD & Organisation for Economic Co-operation and Development \\
\hline OSPAR & Convention for the Protection of the Marine Environment of the North-East Atlantic \\
\hline Out/17, 017 & Outono de 2017 \\
\hline Pal & Palmas \\
\hline $\mathbf{P b}$ & Chumbo \\
\hline PCA & Análise de componentes principais (principal components analysis) \\
\hline PCBs & Bifenilas policloradas \\
\hline PEXJ & Parque Estadual Xixová-Japuí \\
\hline PMSF & Fluoreto de fenilmetilsulfonila \\
\hline $\mathbf{P R}$ & Paraná \\
\hline Prim/08, P08 & Primavera de 2008 \\
\hline Prim/16, P16 & Primavera de 2016 \\
\hline Prot & Proteína total \\
\hline
\end{tabular}




$\begin{array}{ll}\text { PTc } & \text { Conteúdo de proteína total de S15 } \\ \text { PTh } & \text { Conteúdo de proteína total de FH } \\ \text { RMBS } & \text { Região Metropolitana da Baixada Santista } \\ \text { RN } & \text { Rio Grande do Norte } \\ \text { ROS } & \text { Espécies reativas de oxigênio } \\ \text { S15 } & \text { Fração sobrenadante após centrifugação } \\ \text { San } & \text { Santos } \\ \text { Se } & \text { Selênio } \\ \text { SES } & \text { Sistema Estuarino de Santos } \\ \text { SP } & \text { São Paulo } \\ \text { TBA } & \text { Ácido tiobarbitúrico } \\ \text { TBARS } & \text { Substâncias reativas do ácido tiobarbitúrico } \\ \text { TCA } & \text { Ácido tricloroacético } \\ \text { TMP } & \text { Tetrametoxipropano } \\ \text { UNEP } & \text { United Nations Environment Programme } \\ \text { UNESCO } & \text { United Nations Educational, Scientific and Cultural Organization } \\ \text { Ver/09, V09 } & \text { Verão de 2009 } \\ \text { Zn } & \text { Zinco }\end{array}$




\section{Sumário}

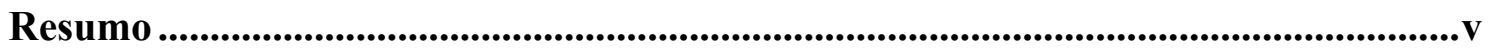

Abstract ....................................................................................................................................................vi

Lista de figuras ............................................................................................................................... vii

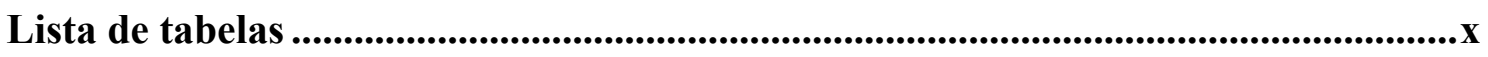

Lista de abreviaturas e siglas .............................................................................. xiii

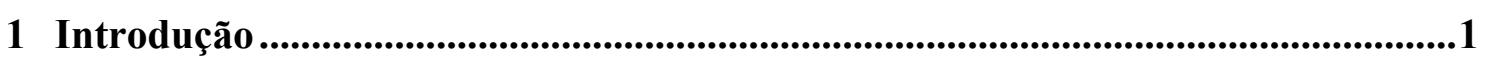

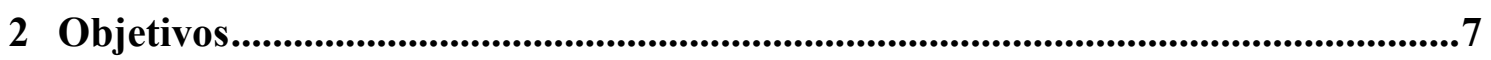

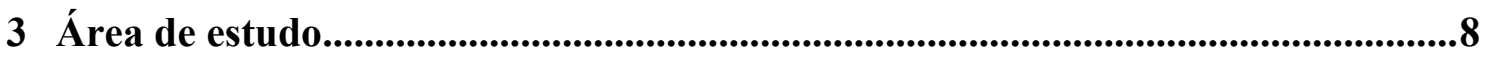

3.1 Sistema Estuarino de Santos e Baía de Santos...............................................................9

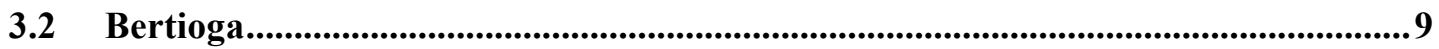

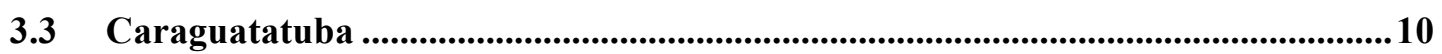

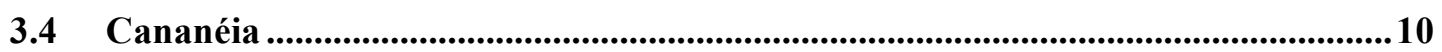

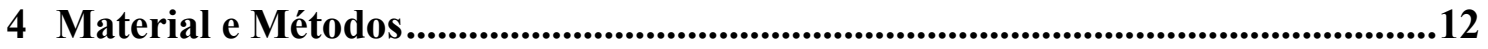

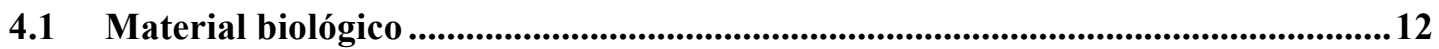

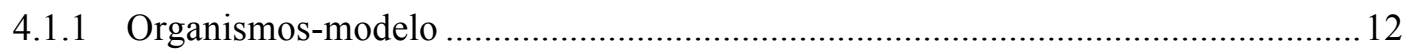

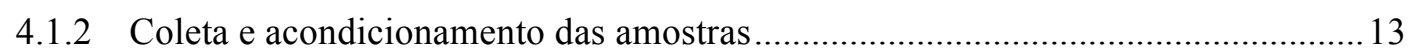

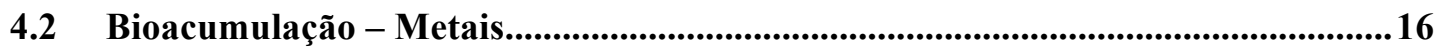

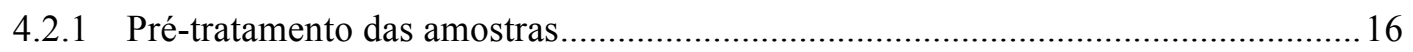

4.2.2 Preparo das amostras: liofilização e moagem ....................................................... 17

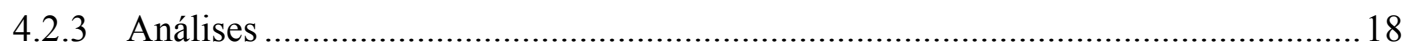

4.2.3.1 Ativação com nêutrons instrumental (INAA) ……………………………………...... 18

4.2.3.2 Espectrometria de absorção atômica (AAS) ……................................................... 19

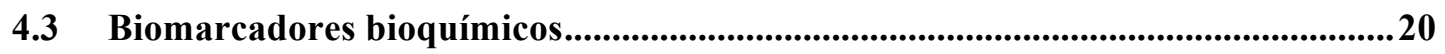

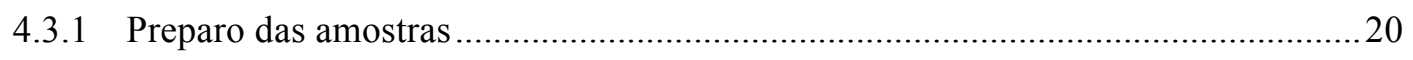

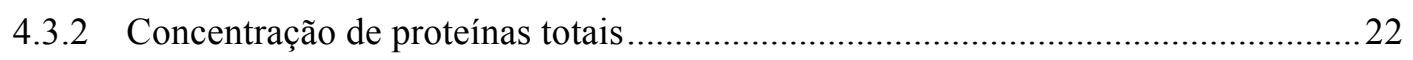

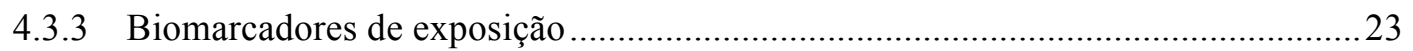

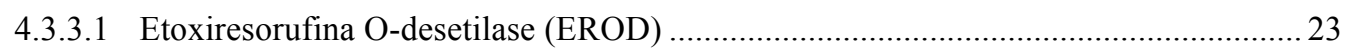

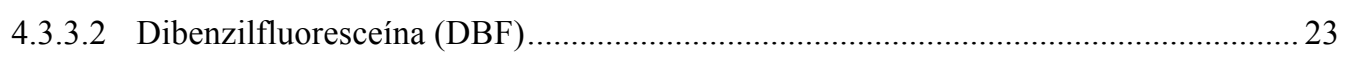

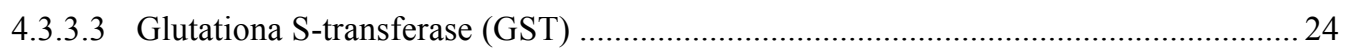

4.3.3.4 Tióis reduzidos não-proteicos (GSH) ................................................................ 24

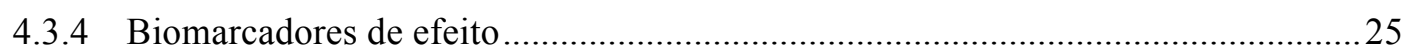

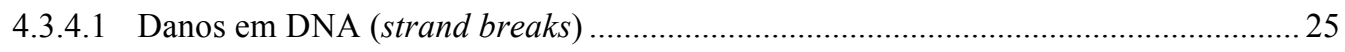

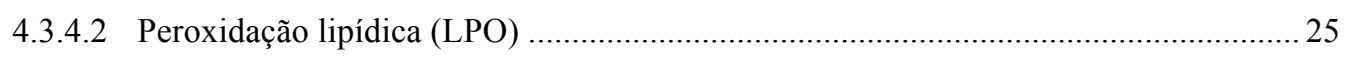

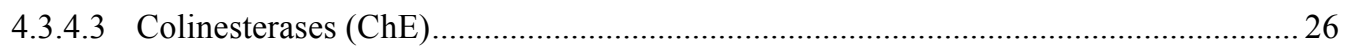

4.4 Biomarcador fisiológico...................................................................................................26

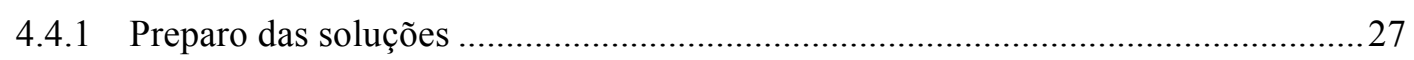




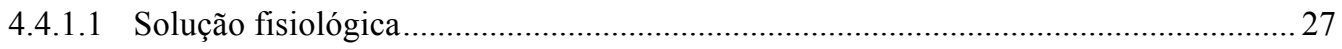

4.4.1.2 Solução de vermelho neutro ............................................................................... 27

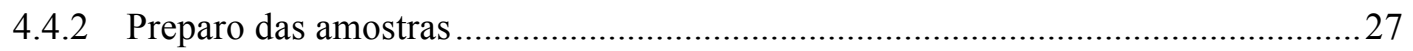

4.4.3 Ensaio de tempo de retenção do vermelho neutro..............................................29

4.5 Análise dos resultados ..................................................................................30

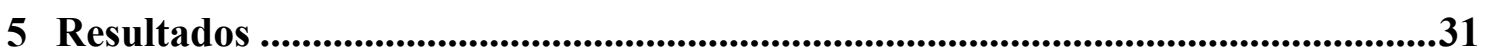

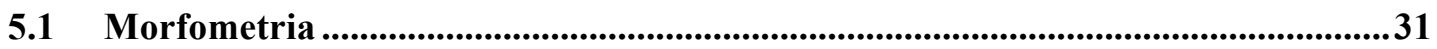

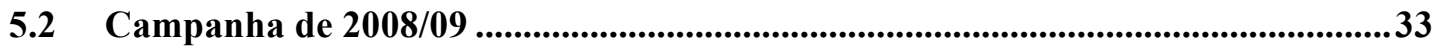

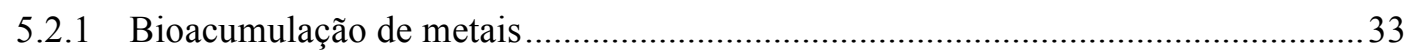

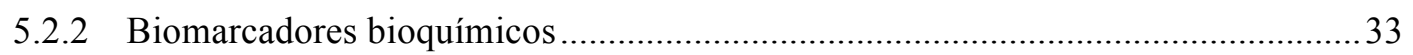

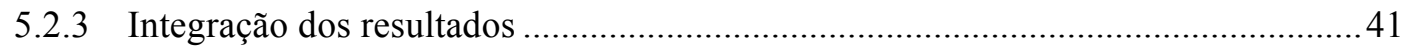

5.3 Campanha de 2016/17 .......................................................................44

5.3.1 Bioacumulação de metais............................................................................... 44

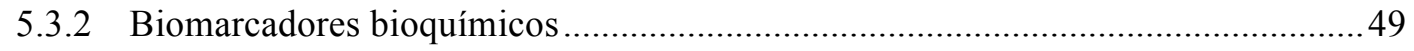

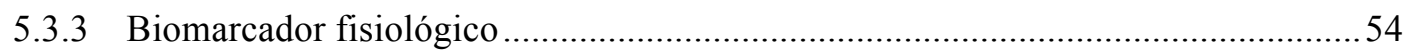

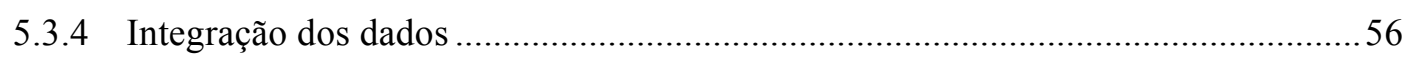

6 Discussão .......................................................................................................58

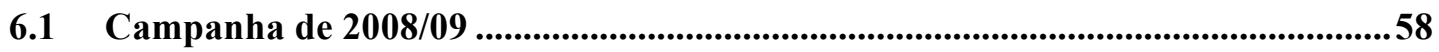

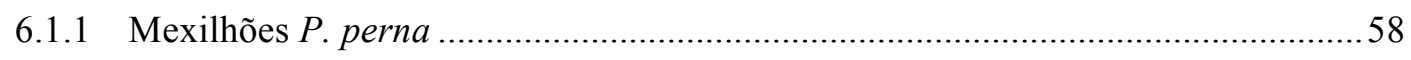

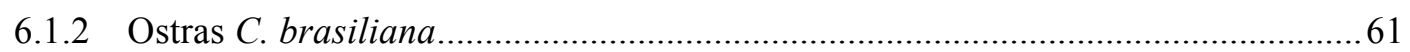

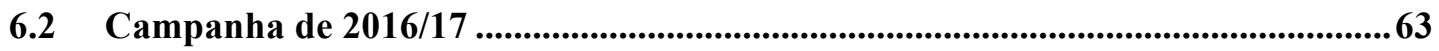

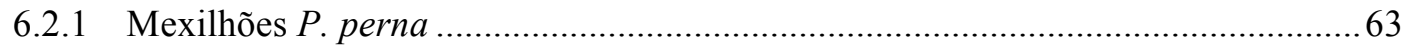

6.2.2 Ostras C. brasiliana........................................................................................ 70

6.3 Discussão geral ........................................................................................... 75

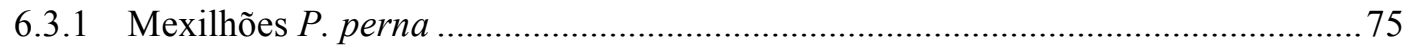

6.3.2 Ostras C. brasiliana............................................................................. 78

7 Conclusões .....................................................................................................80

Referências bibliográficas ........................................................................................82

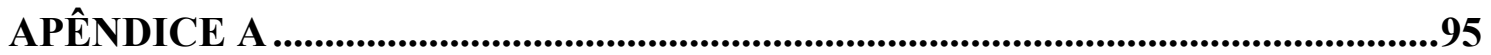

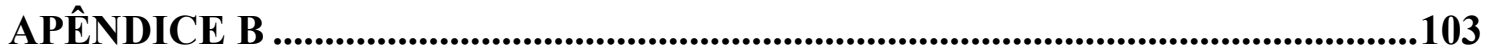

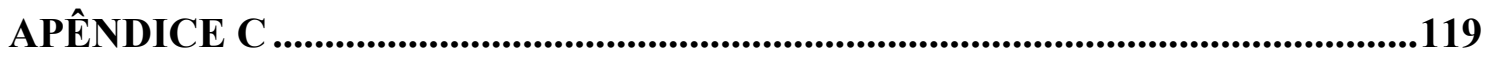

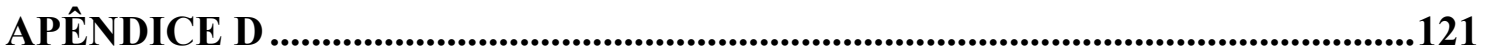




\section{Introdução}

Os ambientes marinhos e estuarinos localizam-se nas zonas costeiras, onde estão situados grandes centros urbanos densamente povoados. Estes ecossistemas acabam sofrendo impactos em decorrência da influência direta e indireta das atividades antrópicas tanto terrestres quanto marinhas (GESAMP, 2001; Halpern et al., 2008). Isso ocorre porque o sistema aquático atua como receptor final de muitas substâncias químicas orgânicas e inorgânicas em função do rápido processo de urbanização e, consequentemente, da geração e descarte de grande quantidade de resíduos, efluentes e emissões industriais, agrícolas, comerciais e domésticas (Valavanidis \& Vlachogianni, 2010; van der Oost et al., 2003).

O resultado é um cenário complexo em que a heterogeneidade do meio ambiente natural conjuga-se à presença destes contaminantes, tornando difícil a avaliação e quantificação dos efeitos da contaminação (Adams, 2005). Em contrapartida, a comunidade científica tem desenvolvido ferramentas para estimar tais efeitos adversos e seus potenciais riscos à biota e aos ecossistemas aquático e terrestre (Hanson \& Larsson, 2010). Neste contexto, a avaliação da qualidade ambiental é utilizada visando fornecer informações importantes que sirvam como subsídio para decisões ambientais e auxiliem na definição de prioridades para a gestão ambiental que tenham como objetivo a conservação, evitando maior degradação destes ambientes costeiros (Martín-Díaz et al., 2008).

Dentre a ampla variedade de métodos científicos disponíveis, análises químicas, ensaios ecotoxicológicos e indicadores ecológicos tem sido amplamente empregados com o intuito de investigar a contaminação ambiental e seus efeitos sobre a biota (Carr et al., 2008; Chapman, 2007). As análises químicas são utilizadas para detectar a presença de substâncias químicas e suas concentrações (Costa et al., 2008). Os ensaios ecotoxicológicos, por sua vez, são recomendados para avaliar seus efeitos (Costa et al., 2008), enquanto comunidades biológicas podem funcionar como indicadoras da integridade dos ecossistemas (Neves \& Valentin, 2011; Wallace, 2007).

Entretanto, a análise química sozinha não proporciona informações suficientes sobre o significado ecológico da contaminação (Abessa, 2002), enquanto ensaios ecotoxicológicos e estudos de comunidades biológicas são limitados à detecção dos efeitos apenas quando são expressos em níveis maiores de organização biológica (i.e. população, comunidade) (Martínez-Gómez et al., 2010). 
O uso de biomarcadores em diagnósticos ambientais pode fornecer informações prévias sobre efeitos adversos em níveis menores de organização biológica (i.e. bioquímicos, celulares, ou fisiológicos) (Martínez-Gómez et al., 2010; van der Oost et al., 2003). Este método leva em consideração a maior probabilidade destes efeitos subletais surgirem devido à presença contínua de baixas concentrações de contaminantes e tem sido proposto por sua alta sensibilidade, curto prazo de resposta e baixo custo de análise (Handy et al., 2003; Pereira, 2008), inclusive sendo recomendado por diversos órgãos internacionais como UNEP (United Nations Environment Programme) e OECD (Organisation for Economic Co-operation and Development) e adotado em convenções internacionais como OSPAR (Convention for the Protection of the Marine Environment of the North-East Atlantic) e ICES (International Council for the Exploration of the Sea) (Cajaraville et al., 2000; Solé et al., 2009).

Biomarcadores podem ser definidos como medidas funcionais de exposição a ou efeitos de estressores ambientais, as quais são expressas em níveis suborganismo (i.e., bioquímico, fisiológico, ou histológico) (Adams, 2005; Huggett, 1992). Essa abordagem parte do princípio de que a presença de um determinado produto químico não implica em sinais visíveis de perturbação entre os componentes do ecossistema, sendo que os danos causados se iniciam com alterações de processos bioquímicos e moleculares no interior das células (Cheung et al., 1998; Corsi et al., 2005). O resultado pode ser o desenvolvimento de doenças ou mudanças de comportamento, eventualmente levando à morte do organismo e produzindo alterações ecológicas (Bresler et al., 1999).

De maneira geral, os biomarcadores podem ser classificados como sendo de exposição ou de efeito. O primeiro tipo oferece estimativas quantitativas e qualitativas sobre a exposição dos organismos a xenobióticos, sendo avaliados através da quantificação dos contaminantes, seus metabólitos ou do produto da interação entre a substância exógena e uma molécula-alvo; enquanto os biomarcadores de efeito são alterações bioquímicas, fisiológicas ou comportamentais que comprometem a saúde do organismo, associados especificamente aos mecanismos de ação dos xenobióticos (Chambers et al., 2002; Hagger et al., 2011; WHO, 1993).

Neste sentido, o metabolismo é um determinante importante da atividade de um composto, da duração desta atividade e da meia-vida do composto no organismo e pode fornecer sinal prévio de seus efeitos negativos (Jesus \& Carvalho, 2008; Timbrell, 2009). Seu estudo representa uma ferramenta útil para o monitoramento destes impactos antes que atinjam níveis superiores de organização biológica, sendo particularmente 
importante na avaliação da contaminação ambiental em áreas pouco ou moderadamente afetadas (Bonacci et al., 2007; Corsi et al., 2005).

O metabolismo de xenobióticos se caracteriza pela biotransformação de substâncias exógenas em uma ou mais moléculas (metabólitos), catalisada pela ação de enzimas. Este processo modifica as propriedades físico-químicas do xenobiótico, geralmente aumentando sua solubilidade em água, seu tamanho e seu peso molecular, de forma a facilitar sua excreção e, consequentemente, diminuir sua acumulação nos tecidos dos organismos (Timbrell, 2009).

Basicamente, o metabolismo dos contaminantes pode ser dividido em duas fases (Figura 1). A fase I consiste na biotransformação pelo sistema de oxidases de função mista (MFO, sigla em inglês para mixed-function oxidases) e envolve a oxidação, redução ou hidrólise de substratos lipofílicos (van der Oost et al., 2003). As enzimas pertencentes a este grupo dependem de uma família de hemeproteínas capazes de catalisar reações oxidativas por meio da utilização de $\mathrm{NADPH}$ e $\mathrm{O}_{2}$. A este conjunto de proteínas denomina-se citocromo P450 (CYP450), localizado no retículo endoplasmático e encontrado em quase todos os organismos (Stegeman \& Hahn, 1994).

A fase II do metabolismo compreende reações de conjugação de moléculas endógenas (e.g. tripeptídeo glutationa) aos contaminantes, tornando-os mais polares e mais facilmente excretados. As enzimas atuantes nesta fase desempenham papel importante na homeostase bem como na detoxificação e depuração de vários xenobióticos (van der Oost et al., 2003).

As mudanças nessas atividades enzimáticas, causadas pela exposição a contaminantes, reflete em um aumento na produção de espécies reativas de oxigênio (ROS) (e.g. $\mathrm{O}_{2}{ }^{--}, \mathrm{OH}^{\bullet}, \mathrm{H}_{2} \mathrm{O}_{2}$, entre outros) (Valavanidis et al., 2006). Estas espécies reagem com ácidos nucleicos, lipídios, carboidratos e proteínas, danificando a célula, e são reguladas por um sistema antioxidante, o qual envolve reações enzimáticas e nãoenzimáticas. Quando esta defesa não é suficiente para contrapor as forças pró-oxidantes, instala-se um estresse oxidativo, potencialmente prejudicial à saúde dos organismos (Bainy et al., 1996; Nunes et al., 2008). As consequências são danos celulares, como a peroxidação lipídica e danos no DNA e em organelas (Almeida et al., 2007).

Os lisossomos são organelas subcelulares envolvidas em vários processos celulares, incluindo digestão de componentes celulares, defesa e reprodução, e se constituem como um dos principais locais de detoxificação de poluentes orgânicos e metais tóxicos (Moore, 1985; Viarengo et al., 1987). Recentemente, eles se tornaram 
foco de estudos toxicológicos, pois são fáceis de visualizar nas células sanguíneas e estão presentes em todas as células nucleadas, não sendo uma característica espécieespecífica (Domouhtsidou et al., 2004).

A estabilidade da membrana lisossomal é a principal resposta destas organelas a uma ampla gama de contaminantes e tem sido considerada um biomarcador muito confiável de estresse generalizado em estudos de biomonitoramento (Viarengo et al., 2007). Atualmente, está incluída em diretrizes gerais para o monitoramento dos efeitos de contaminantes do JAMP (Joint Assessment Monitoring Programme) da OSPAR e é proposta como um índice de poluição marinha para avaliar respostas de estresse em moluscos no Programa MEDPOL (Mediterranean Pollution Programme) (UNEP, 2007). Sua avaliação pode ser feita principalmente através de duas técnicas: o ensaio citoquímico em secções criostáticas congeladas não fixadas de glândula digestiva ou o ensaio de tempo de retenção do corante vermelho neutro (NRRT) em hemócitos vivos (Martínez-Gómez et al., 2008).

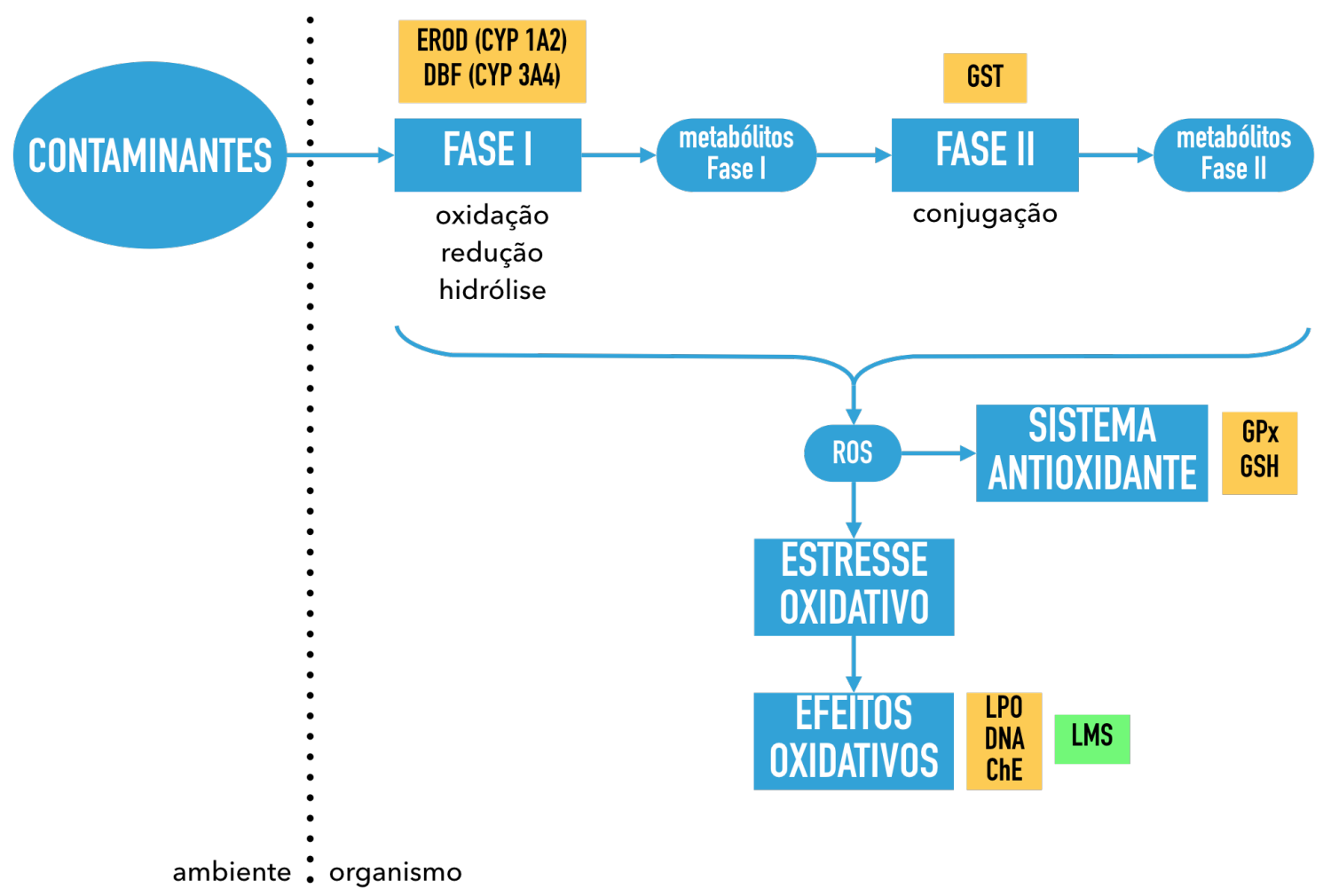

Figura 1. Diagrama representando as diferentes fases do metabolismo de contaminantes dentro dos organismos (retângulos azuis), seus produtos (retângulos azuis arredondados) e os biomarcadores bioquímicos (retângulos amarelos) e fisiológico (retângulo verde) relacionados a cada uma delas. (CYP) família de citocromos; (EROD) etoxiresorufina O-desetilase; (DBF) dibenzilfluoresceína; (GST) glutationa S-transferase; (ROS) espécies reativas de oxigênio; (GPx) glutationa peroxidase; (GSH) tripeptídeo glutationa; (LPO) peroxidação lipídica; (DNA) danos em DNA; (ChE) colinesterases; (LMS) estabilidade de membrana lisossômica. Adaptado de Maranho (2014). 
Diversos estudos comprovaram ser bem-sucedido o uso da abordagem multibiomarcadores em invertebrados com o intuito de avaliar efeitos da poluição sobre estes organismos (Cravo et al., 2012; Díaz-Jaramillo et al., 2011; Galloway et al., 2004; Maranho et al., 2012; Morales-Caselles et al., 2009; Pereira et al., 2012; Sardi et al., 2016; Solé et al., 2009; Turja et al., 2013). Dentre os modelos biológicos mais utilizados, moluscos bivalves filtradores tem sido empregados como organismos sentinela em estudos de monitoramento da contaminação química e da qualidade ambiental desde meados da década de 1970 (IMW, 1995). Foi nesta época que o Mussel Watch foi inicialmente proposto como um programa internacional de monitoramento marinho empregando a análise de mexilhões (ou espécies similares) como organismos sentinela da contaminação (Goldberg, 1975).

Os bivalves constituem excelentes organismos bioindicadores, pois possuem hábitos sedentários e são capazes de bioconcentrar poluentes (Almeida et al., 2007). Eles possuem grande importância ecológica por seu papel fundamental na transferência de contaminantes para outros níveis tróficos, considerando que servem de alimentação para aves marinhas e costeiras, peixes e mamíferos (incluindo o ser humano) (Yusof et al., 2004). Além disso, apresentam também importância socioeconômica, uma vez que seu cultivo constitui uma fonte alternativa de renda para pescadores do litoral do Brasil (Carraro et al., 2012; CETESB, 2009). O mexilhão Perna perna e a ostra Crassostrea brasiliana são bivalves presentes no litoral brasileiro e tem sido extensivamente utilizados em estudos de biomonitoramento da contaminação ambiental (Catharino et al., 2015; 2012; Pereira et al., 2012; Seo et al., 2013) e mensurações subletais como as respostas bioquímicas (Abessa et al., 2005b; Francioni et al., 2007; Lüchmann et al., 2015; Maranho et al., 2012; Nogueira et al., 2015; Zanette et al., 2006) e a estabilidade da membrana lisossomal (Cheung et al., 1998; Song et al., 2007).

Dentre os diversos tipos de contaminantes, os metais tem sido reportados como sendo de grande preocupação ambiental, pois, uma vez no ambiente marinho, interagem com a água, os sedimentos e os organismos (Torres et al., 2015). Devido à sua persistência no ambiente, sua potencial toxicidade e sua tendência de bioacumulação, a quantificação destas substâncias nos organismos tem especial valor, pois elas não são metabolizadas (Luoma \& Rainbow, 2005). Portanto, estudos de bioacumulação de metais fornecem boas informações sobre a biodisponibilidade destes contaminantes, a qual irá depender das condições ambientais, podendo ser influenciada por efeitos 
geoquímicos (Bryan \& Langston, 1992; Smith et al., 2012). Ou seja, a biodisponibilidade dos metais está associada à sua forma química predominante, que por sua vez está relacionada a uma série de fatores como $\mathrm{pH}$, dureza, alcalinidade, presença de quelantes, entre outros (Stumm \& Morgan, 1995).

O litoral do estado de São Paulo vem sofrendo intensa ocupação urbana e industrial nos últimos 50 anos, sendo que o esgoto doméstico, a drenagem urbana e os efluentes industriais são descartados com pouco ou nenhum tratamento, diretamente nos estuários e no mar (Ambrozevicius \& Abessa, 2008). Estudos tem demonstrado a presença de contaminantes e toxicidade na água e sedimento desta região (Abessa, 2002; Araujo et al., 2013; Camargo et al., 2015; Cesar et al., 2007; Sousa et al., 2014), bem como bioacumulação de contaminantes e alterações fisiológicas em organismos marinhos (Catharino et al., 2012; Lamparelli et al., 2001; Pereira et al., 2007).

Neste contexto, a Região Metropolitana da Baixada Santista (RMBS), situada na porção central do litoral paulista, possui um dos mais antigos núcleos urbanos do Brasil, tendo se desenvolvido de maneira rápida e desordenada a partir da segunda metade do século XX e apresentando grande importância econômica. Esta região constitui um ambiente que possibilita a utilização de bivalves filtradores como bioindicadores da contaminação, uma vez que ali estão presentes diversas fontes de contaminação devido à presença do polo industrial de Cubatão, o Porto de Santos e à grande demanda turística. Desta maneira, a avaliação integrada da contaminação e dos seus efeitos sobre estes organismos, no que diz respeito à bioacumulação de contaminantes e às respostas bioquímicas e fisiológicas, se coloca como uma excelente ferramenta para monitorar a evolução da qualidade ambiental da RMBS. 


\section{Objetivos}

Este trabalho teve como objetivo avaliar a bioacumulação de contaminantes e as respostas biológicas de bivalves filtradores expostos à contaminação por fontes constantes, complexas e difusas presentes na Baixada Santista. A partir disso, pretendeu-se avaliar a variação temporal da contaminação e analisar as possíveis modificações dos impactos sobre a biota aquática nesses períodos.

Para tanto, foram propostos os seguintes objetivos específicos:

- Avaliar a bioacumulação de metais em mexilhões Perna perna e ostras Crassostrea brasiliana coletados na Baixada Santista e em áreas de referência (Praia da Cocanha e Cananéia, respectivamente) em duas campanhas ao longo de um ano;

- Avaliar a atividade dos biomarcadores bioquímicos de exposição EROD, DBF, GST e GSH nos mexilhões e ostras coletados e em brânquias de mexilhões e ostras coletados em diferentes estações do ano ao longo de 2008/09;

- Avaliar os níveis de danos em DNA, de peroxidação lipídica e a atividade das colinesterases como biomarcadores bioquímicos de efeitos da contaminação nos mexilhões e ostras coletados e em brânquias de mexilhões e ostras coletados em diferentes estações do ano ao longo de 2008/09;

- Avaliar a integridade da membrana lisossomal nos mexilhões e ostras coletados através do ensaio de tempo de retenção do vermelho neutro.

- Analisar diferenças temporais em relação à bioacumulação de metais e às respostas dos biomarcadores nos distintos locais de estudo. 


\section{3 Área de estudo}

A área de estudo compreende a Região Metropolitana da Baixada Santista (RMBS) $\left(23^{\circ} 40^{\prime}-24^{\circ} 25^{\prime} \mathrm{S} ; 45^{\circ} 47^{\prime}-47^{\circ} 7^{\prime} \mathrm{W}\right)$, localizada na porção central do litoral do estado de São Paulo e que inclui os municípios de Bertioga, Cubatão, Guarujá, Itanhaém, Mongaguá, Peruíbe, Praia Grande, Santos e São Vicente (Figura 2). A região sofre forte influência marítima em função da presença da Serra do Mar, a qual dificulta que as massas de ar úmidas vindas do oceano sejam carregadas para o interior, detendoas sobre a região litorânea, constituindo um clima tropical quente e úmido, com alto índice de precipitação, principalmente nos meses de verão (Fierz \& Rosa, 1999; Seluchi et al., 2011).

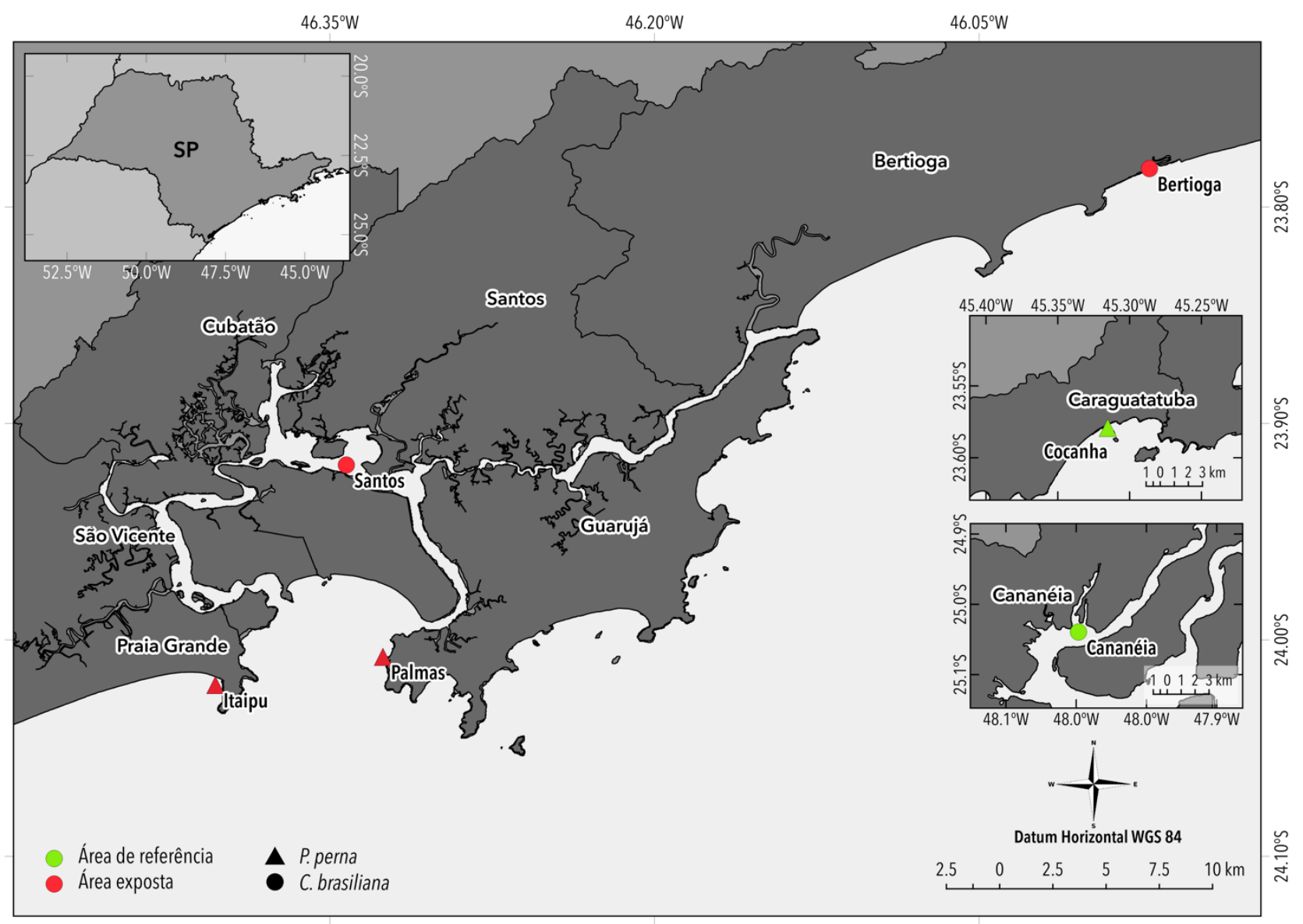

Figura 2. Mapa da área de estudo indicando a localização dos pontos de coleta de mexilhões $P$. perna $(\boldsymbol{\Delta})$ e ostras C. brasiliana (•) na Região Metropolitana da Baixada Santista (RMBS), litoral centro; na Praia da Cocanha, litoral norte; e em Cananéia, litoral sul do estado de São Paulo. Marcadores verdes indicam áreas consideradas referência de qualidade, enquanto marcadores vermelhos indicam áreas possivelmente sujeitas à contaminação. 
A seguir, são descritas as regiões específicas onde o material biológico analisado no presente trabalho foi coletado nas campanhas de 2008/09 e 2016/17, a fim de caracterizar as condições às quais a biota aquática está sujeita e o histórico de mudanças nas fontes de poluição em cada uma das regiões. Assim, a RMBS foi dividida entre Sistema Estuarino de Santos e Baía de Santos, e Bertioga. Caraguatatuba e Cananéia, regiões distantes da RMBS, foram consideradas referências de qualidade.

\subsection{Sistema Estuarino de Santos e Baía de Santos}

O Sistema Estuarino de Santos (SES) possui grande importância econômica, pois inclui cidades de grande porte e densamente povoadas e apresenta três setores econômicos principais: o turismo, responsável por grande parte da economia de algumas das cidades locais; as indústrias, situadas no interior do estuário, constituindo um dos mais importantes polos industriais do Brasil e incluindo químicas, petroquímicas, fertilizantes e importantes siderúrgicas; e o porto de Santos, o maior da América Latina, ocupando um trecho das margens da área estuarina (Braga et al., 2000; Lamparelli et al., 2001; Luiz-Silva et al., 2002; Rachid, 2002; São Paulo, 2010).

Como resultado, a região apresenta densa mancha urbana, com alto grau de conurbação entre os municípios e elevados níveis de degradação ambiental, devido à disposição de compostos perigosos nos rios e nas áreas estuarina e marinha, incluindo nutrientes, metais, compostos orgânicos, hidrocarbonetos de petróleo, fármacos, organoestânicos e outros contaminantes (Braga et al., 2000; Lamparelli et al., 2001; Luiz-Silva et al., 2002; Tommasi, 1979). Por outro lado, a região do SES possui grande relevância ambiental, devido aos recursos pesqueiros e à presença de manguezais, além de uma complexidade paisagística em função de se caracterizar como um ambiente de transição entre o litoral norte e sul do estado (Abessa, 2002).

A Baía de Santos tem cerca de $7 \mathrm{~km}$ de largura na parte central e $11 \mathrm{~km}$ na parte final, entre as Pontas de Itaipu a oeste e do Monduba a leste, e uma profundidade média de 5 a $10 \mathrm{~m}$. Ela recebe águas do SES, sendo sua circulação governada predominantemente pelo regime de marés (enchente e vazante) (Fukumoto et al., 2004).

\subsection{Bertioga}

O município de Bertioga situa-se na porção mais ao norte da RMBS e possui áreas de mata de restinga bastante preservadas (S. E. Martins et al., 2008). A população dedicou-se às atividades extrativistas de pequeno porte, como a pesca, artesanato e a 
agricultura de subsistência, o que permitiu à região livrar-se do intenso processo de degradação ambiental durante a industrialização paulista. Entre os anos 1970 e 1980, novas rodovias (em especial, a BR-101) facilitaram o acesso ao município, bem como o escoamento da produção. Consequentemente, o aumento do turismo, a ocupação desordenada e a especulação imobiliária sem planejamento tem causado significativos impactos ambientais na região, tais como o desmatamento e a contaminação das praias (S. E. Martins et al., 2008; Morais et al., 2011).

Complementarmente, a infraestrutura de saneamento básico do município atende apenas cerca de $30 \%$ do esgoto produzido pela população, insuficiente para garantir a qualidade ambiental tanto à população residente quanto à população visitante nas altas temporadas (CETESB, 2017). Neste contexto, apesar de não possuir emissários submarinos (como os demais municípios da RMBS), a presença de fontes pontuais de esgoto doméstico não tratado tende a comprometer a qualidade das águas devido à deposição de matéria orgânica, poluição fecal, e substâncias potencialmente tóxicas como mercúrio, arsênio, surfactantes, hidrocarbonetos e fármacos (Morais et al., 2011; Sousa et al., 2014).

\subsection{Caraguatatuba}

Caraguatatuba é o maior município do litoral norte de São Paulo. Conta com comércio diversificado, infraestrutura e setor de serviços bem desenvolvidos. Em relação ao ambiente costeiro, a região é caracterizada por águas oligomesotróficas, influenciadas por ressurgência sazonal (Aidar et al., 1993; Bernadochi et al., 2016; Castro-Filho \& Miranda, 1998). A Praia da Cocanha está localizada na região norte do município, em área de média ocupação com fontes de poluição originadas principalmente de efluentes domésticos de esgotos e da intensa atividade de maricultura, desenvolvida principalmente próximo às ilhas da Cocanha Grande (Massaguaçu) e da Cocanha Pequena (CETESB, 2008).

\subsection{Cananéia}

Desde 1993, a região de Cananéia, que se estende entre o Rio Ribeira de Iguape (SP) e a Baía do Paranaguá (PR), é reconhecida pela UNESCO (United Nations Educational, Scientific and Cultural Organization) como parte da Reserva da Biosfera da Mata Atlântica, área de grande importância enquanto meio natural e de culturas tradicionais; e, em 1999, foi declarada Patrimônio Histórico Natural da Humanidade 
pela mesma organização (São Paulo, 2012). Além disso, ela tem um importante papel no Plano Estadual de Gerenciamento Costeiro (SMA, 1997). A distância entre a Serra do Mar e o mar resulta numa ampla planície litorânea, ocupada pela Mata Atlântica e por vastas áreas de manguezais, sendo Cananéia o município paulista com maior área de manguezal, seguido por Iguape (CETESB, 2017).

Ali encontra-se o Complexo Estuarino-Lagunar Cananéia-Iguape-Peruíbe, que constitui um dos grandes berçários marinhos do planeta, havendo várias unidades de conservação estaduais e federais que se sobrepõem, no intuito de preservar a ampla gama de espécies da fauna e flora locais (CETESB, 2017). Este ambiente é considerado o maior produtor de ostras da região Sul-Sudeste do Brasil, sendo que a maior parte do fornecimento de ostras é proveniente de Cananéia (Pereira et al., 2001b; 2001a) e uma parcela significativa da população vive da subsistência, com base na pesca e extração de ostras, e outras atividades (Chamy \& Maldonado, 2002; Mendonça, 2007). 


\section{Material e Métodos}

\subsection{Material biológico}

\subsubsection{Organismos-modelo}

A classe Bivalvia é constituída por moluscos bivalves, os quais são achatados lateralmente e possuem uma concha composta de duas valvas, encaixadas em dobradiça dorsalmente, que envolvem todo o corpo. Abrange animais comuns como as ostras, mexilhões, vieiras e mariscos (Ruppert \& Barnes, 1996). Para este estudo, foram utilizados organismos das espécies Perna perna e Crassostrea brasiliana, cuja classificação taxonômica está representada na Tabela 1.

O mexilhão Perna perna (Figura 3A,B) é comumente encontrado em todo o litoral brasileiro e também na costa da Venezuela, Uruguai, Argentina e África do Sul (Rios, 1984) e constitui grande fonte de alimentação humana, sendo cultivado em grande escala visando a comercialização. Pode ser encontrado fixo a rochas na região entremarés, em áreas de alto hidrodinamismo, formando densos bancos naturais. Estes organismos alimentam-se por filtração, assimilando partículas suspensas na água, através das brânquias.

A ostra Crassostrea brasiliana (Figura 3C,D), por sua vez, é um molusco com grande capacidade de converter a produção primária marinha em proteína animal por meio da filtração de uma grande quantidade de água através do seu mecanismo de alimentação. Esta espécie, nativa do Brasil, é naturalmente abundante em manguezais do litoral sul do estado de São Paulo e, por este motivo, é um produto de grande importância econômica e social para a população caiçara da região.

Tabela 1. Classificação taxonômica do mexilhão Perna perna e da ostra Crassostrea brasiliana, ambos organismos-modelo utilizados neste estudo.

\begin{tabular}{lcc}
\hline \multicolumn{1}{c}{ Mexilhão } & Ostra \\
\hline Classe & Bivalvia & Bivalvia \\
Ordem & Mytilida & Ostreida \\
Família & Mytilidae Rafinesque, 1815 & Ostreoidae Rafinesque, 1815 \\
Gênero & Perna Philipsson, 1788 & Crassostrea Sacco, 1897 \\
Espécie & Perna perna (Linnaeus, 1758) & Crassostrea brasiliana (Lamarck, 1819) \\
\hline
\end{tabular}




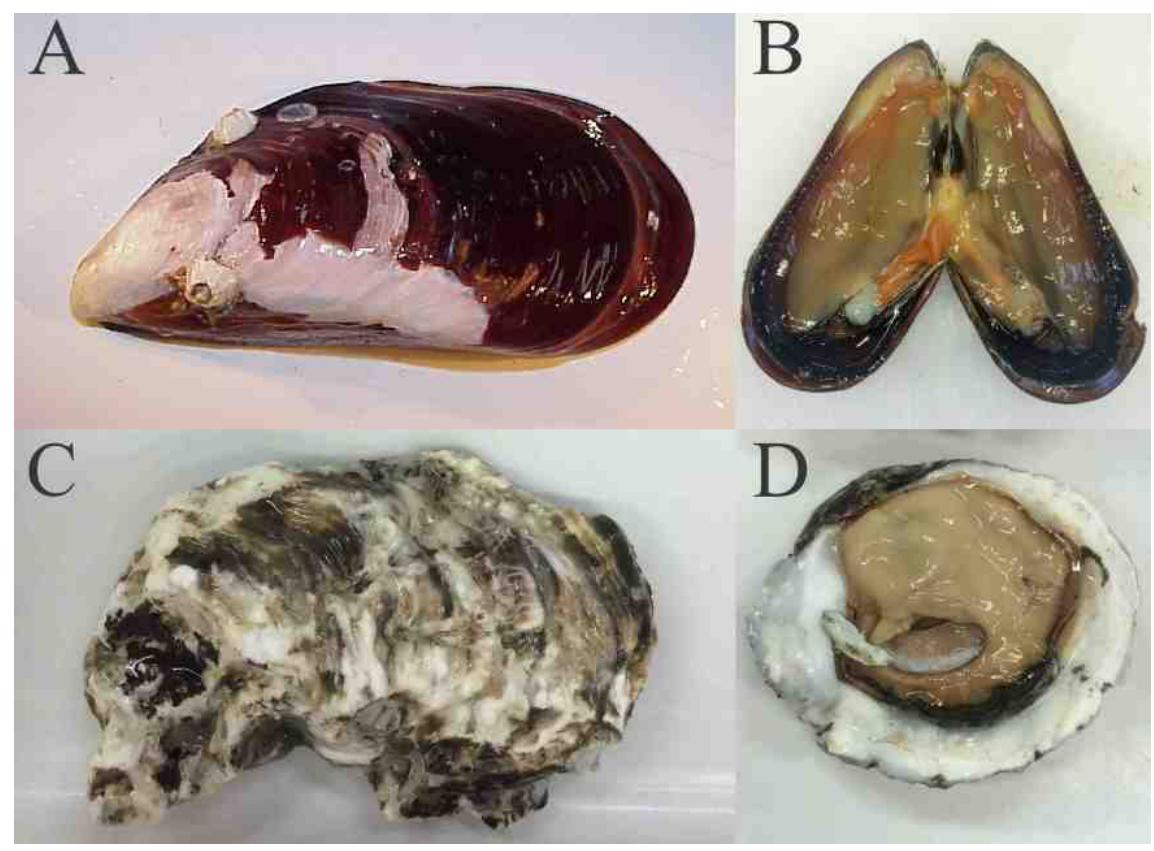

Figura 3. Visão externa (A) e interna (B) do mexilhão Perna perna; e visão externa (C) e interna (D) da ostra Crassostrea brasiliana (Fotos: Júlia Camargo).

\subsubsection{Coleta e acondicionamento das amostras}

Os pontos de coleta foram definidos em locais onde os organismos estão sujeitos a situações de estresse devido à proximidade das áreas a desembocaduras de efluentes industriais e municipais, a atividades portuárias e/ou a corpos receptores com histórico de contaminação (Figura 2 e Tabela 2), com base em estudos anteriores realizados na região (Abessa, 2002; Catharino et al., 2012; Fenili, 2012; Pereira, 2008; Sousa et al., 2014).

Para realização deste trabalho foram utilizados mexilhões da espécie Perna perna e ostras da espécie Crassostrea brasiliana residentes, sendo amostrados cerca de 120 organismos em cada ponto em cada estação do ano. Os mexilhões foram coletados na Ilha das Palmas, que se encontra a leste da Baía de Santos, próximo à desembocadura do Canal de Santos, e na Ponta de Itaipu, a oeste da baía, que sofre influência do estuário. Também foram coletados mexilhões em cultivo localizado na Praia da Cocanha (Caraguatatuba), considerado referência de qualidade. As ostras foram coletadas no rio Itaguaré, em Bertioga, e no estuário de Santos, próximo à Ilha Barnabé e ao antigo aterro sanitário da Alemoa. O cultivo desenvolvido pela Cooperostra (Cooperativa dos Produtores de Ostras de Cananéia), em Cananéia, foi utilizado para coleta de ostras consideradas referência de qualidade. 
Tabela 2. Resumo dos pontos onde foram coletados os mexilhões P. perna e as ostras C. brasiliana. Asteriscos indicam as áreas consideradas referência de qualidade para cada organismo.

\begin{tabular}{ll}
\hline \multicolumn{1}{c}{ Local } & Organismo coletado \\
\hline *Praia da Cocanha, Caraguatatuba & P. perna \\
Ilha das Palmas, Guarujá & P. perna \\
Ponta de Itaipu, Praia Grande & P. perna \\
*Cooperostra, Cananéia & C. brasiliana \\
Ilha Barnabé, Santos & C. brasiliana \\
Rio Itaguaré, Bertioga & C. brasiliana \\
\hline
\end{tabular}

$\mathrm{O}$ material analisado neste trabalho foi coletado em duas etapas distintas. $\mathrm{Na}$ primeira, os organismos foram coletados como parte do trabalho de pós-doutorado da pesquisadora Dra. Marília G. M. C. Semmler (Instituto de Pesquisas Energéticas e Nucleares, IPEN) em 2008/09. Na segunda etapa, as coletas foram realizadas como parte deste trabalho.

As coletas de 2008/09 foram realizadas em todas as estações do ano, com início na primavera de 2008 e término no inverno de 2009, e conduzidas em colaboração com a Marina Náutica Alfredo, por pescadores regionais. As amostras coletadas durante o outono de 2009 não puderam ser analisadas, pois o material foi extraviado. Estas amostras foram utilizadas apenas para as análises de biomarcadores bioquímicos, uma vez que o ensaio de tempo de retenção do vermelho neutro e a análise de bioacumulação de metais foram realizadas anteriormente ao início deste trabalho.

$\mathrm{Na}$ campanha de 2016/17, os organismos foram coletados durante a primavera de 2016 e o outono de 2017, com os quais foram realizadas todas as análises descritas a seguir (bioacumulação de metais, biomarcadores bioquímicos, biomarcador fisiológico).

A retirada dos organismos em ambas as coletas foi realizada com uma espátula de titânio, uma vez que eles se encontram fixos a rochas no entremarés (mexilhões) ou às raízes de árvores e pedras (ostras). Após a coleta dos mexilhões e ostras de todas as campanhas, eles foram transportados vivos em caixa térmica para o Laboratório de Ecotoxicologia Marinha e Microfitobentos (LEcotox) do Instituto Oceanográfíco (IOUSP), onde foram aclimatados em tanques contendo água do mar e aeração constante (Figura 4). Os organismos permaneceram pelo menos um dia no tanque para sua recuperação. Posteriormente, as amostras foram pré-tratadas de maneiras diferentes de acordo com a análise a ser realizada. Os pré-tratamentos para cada análise estão descritos a seguir. 


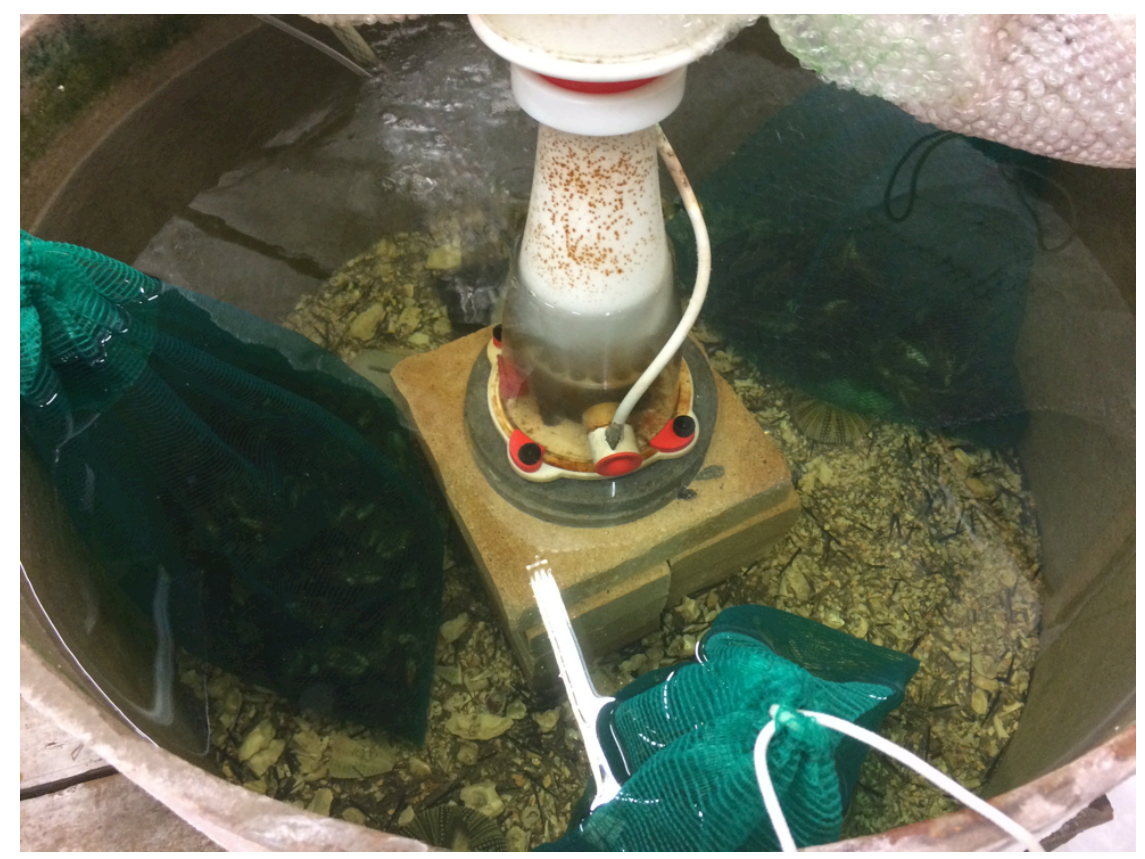

Figura 4. Tanque de água do mar do Laboratório de Ecotoxicologia Marinha e Microfitobentos (LEcotox), onde os organismos coletados (mexilhões e ostras) foram aclimatados por pelo menos um dia antes do preparo das amostras para as análises (Foto: Júlia Camargo).

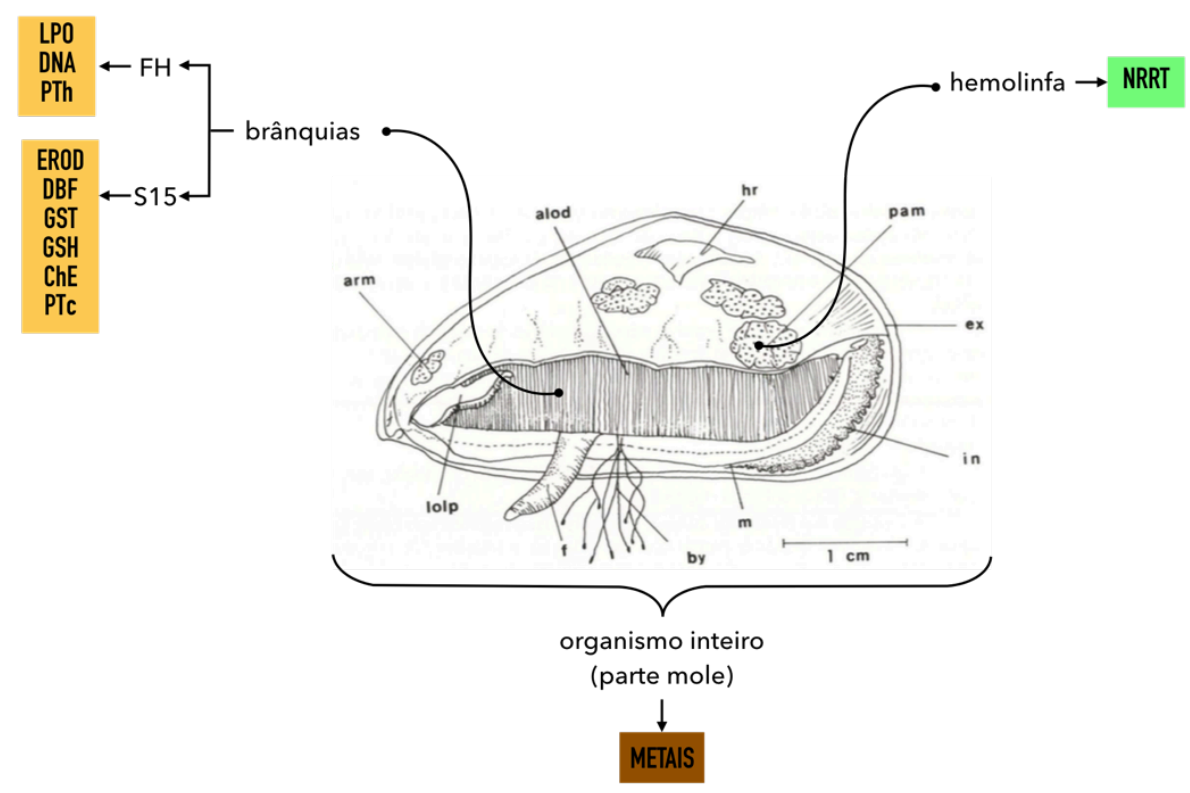

Figura 5. Anatomia interna do mexilhão P. perna (vista do lado esquerdo) após a remoção de parte do manto e esquema demonstrando para quais análises cada parte do organismo foi utilizada. O esquema também é representativo para as ostras C. brasiliana. (alod) lamela ascendente da demibrânquia externa; (arm) músculo anterior retrator do bisso; (by) bisso; (ex) sifão exalante; (f) pé; (frm) músculo retrator do pé; (hr) região do coração; (in) sifão inalante; (lid) resto da demibrânquia interna esquerda; (lod) resto da demibrânquia externa esquerda; (lolp) palpo esquerdo externo; (m) manto; (mrm) músculo mediano retrator do bisso; (pam) músculo adutor posterior; (prm) músculo posterior retrator do bisso; (rid) demibrânquia interna direita; (rilp) palpo labial interno direito; (rod) demibrânquia externa direita; (rolp) palpo labial externo direito; (u) umbo; (FH) fração homogeneizada; (S15) fração sobrenadante após centrifugação a 15.000g; (LPO) peroxidação lipídica; (DNA) danos em DNA; (PTh) conteúdo de proteína total em FH); (EROD) etoxiresorufina O-desetilase; (DBF) dibenzilfluoresceína; (GST) glutationa Stransferase; (GSH) tripeptídeo glutationa; (ChE) colinesterases; (PTc) conteúdo de proteína toal em S15; (NRRT) tempo de retenção do vermelho neutro. Adaptado de Narchi \& Galvão-Bueno (1997). 


\subsection{Bioacumulação - Metais}

As análises químicas de bioacumulação de metais foram realizadas pela Dra. Marília G. M. C. Semmler no Laboratório de Análise por Ativação Neutrônica (LAN) do Instituto de Pesquisas Energéticas e Nucleares (IPEN/CNEN-SP), sob coordenação da Profa. Dra. Marina Beatriz Agostini Vasconcellos. As amostras foram pré-tratadas no LEcotox/IOUSP e transportadas para o LAN/IPEN/CNEN-SP em caixas térmicas com gelo para preparo e realização das análises.

Através da análise por ativação com nêutrons instrumental (INAA), foram quantificados arsênio (As), cobalto $(\mathrm{Co})$, cromo $(\mathrm{Cr})$, ferro $(\mathrm{Fe})$, selênio $(\mathrm{Se})$ e zinco (Zn) nas amostras de tecido de mexilhões e ostras. A quantidade de mercúrio $(\mathrm{Hg})$ foi determinada por espectrometria de absorção atômica com geração de vapor frio (CV $\mathrm{AAS})$, enquanto as determinações de cádmio $(\mathrm{Cd})$ e chumbo $(\mathrm{Pb})$ foram realizadas por meio da espectrometria de absorção atômica com atomização eletrotérmica (ET AAS).

Os resultados obtidos foram comparados aos limites máximos de tolerância estabelecidos pela legislação brasileira para a categoria de outros alimentos, alimentos sólidos e qualquer alimento (Brasil, 1965), ou para moluscos bivalves (Brasil, 2013).

\subsubsection{Pré-tratamento das amostras}

Após a aclimatação dos organismos (mexilhões e ostras), 90 indivíduos foram retirados do tanque e selecionados por tamanho (30 pequenos, 30 médios e 30 grandes) (Figura 6), com medição do comprimento e altura das conchas com um paquímetro. Em seguida, as partes moles dos 90 organismos (Figura 5) foram retiradas das respectivas conchas com uma faca de titânio e trituradas e homogeneizadas em liquidificador com lâminas de titânio (Figura 7A). A massa resultante foi acondicionada em diversos potes plásticos, os quais foram pesados individualmente e armazenados em congelador para posterior liofilização (Figura 7B,C). 


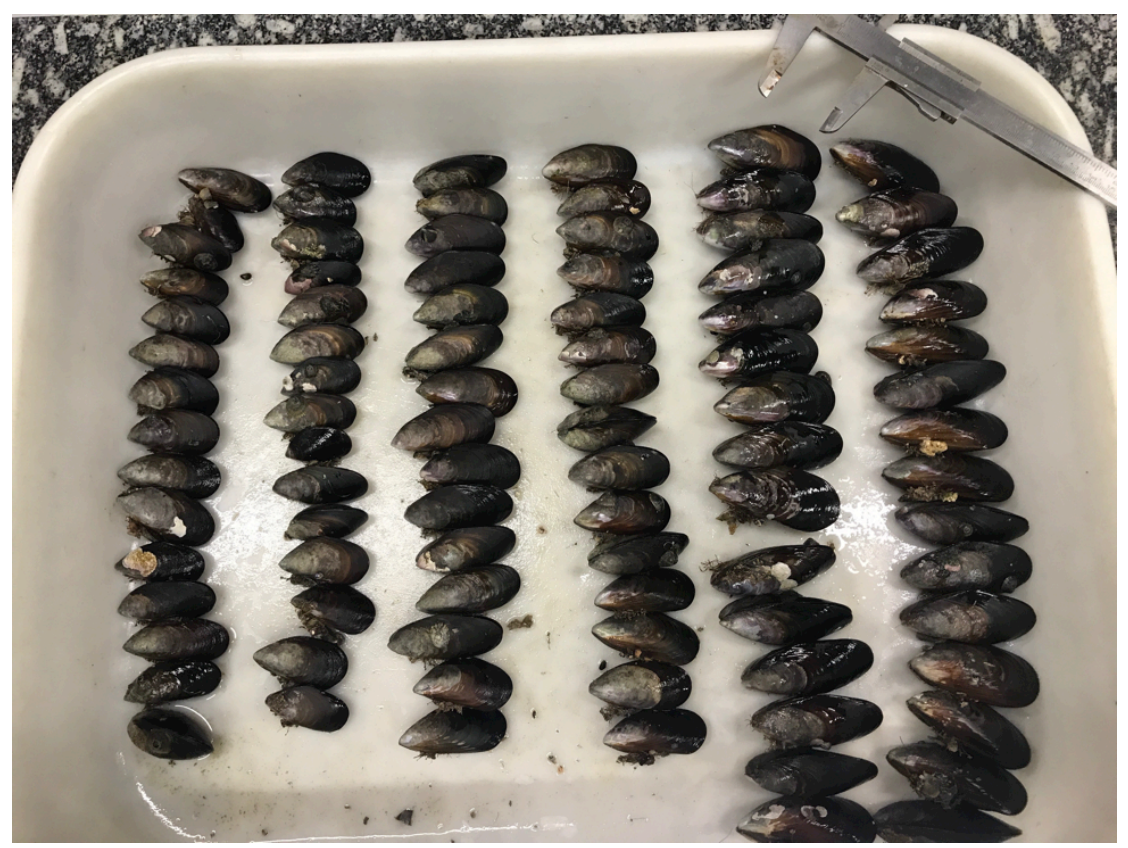

Figura 6. Mexilhões separados por classe de tamanho, sendo 30 pequenos, 30 médios e 30 grandes (nesta ordem). No canto superior direito, o paquímetro utilizado para realizar a biometria. A separação das ostras foi feita da mesma maneira (Foto: Júlia Camargo).
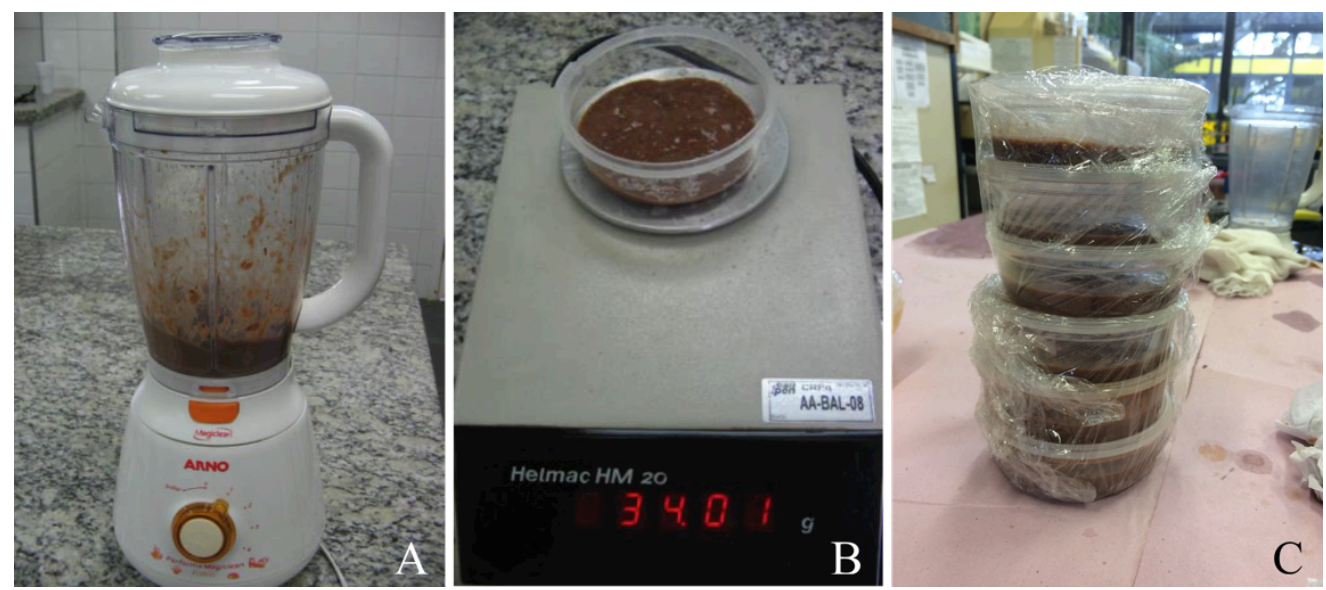

Figura 7. Trituração (A), pesagem (B) e acondicionamento em potes plásticos (C) das amostras de tecido mole dos organismos analisados (Fotos A e B: Marília G.M.C. Semmler; Foto C: Júlia Camargo).

\subsubsection{Preparo das amostras: liofilização e moagem}

A liofilização é um dos métodos mais utilizados para a secagem de materiais biológicos analisados através da ativação por nêutrons, pois diminui o risco de perda de elementos por volatilização. Este procedimento foi realizado a $-52^{\circ} \mathrm{C}$ e pressão de 74 mbar por 48h, no liofilizador Thermo Electron Corporation, modelo ModulyoD-115 ${ }^{\circledR}$, do LAN/IPEN/CNEN-SP (Figura 8A), adequado para manuseio de amostras pequenas.

Após a liofilização, o material foi triturado em liquidificador com lâminas de titânio e peneiradas em malha de 80 mesh (Figura 8B). Por fim, as amostras foram 
acondicionadas em potes plásticos, etiquetadas e armazenadas em freezer para posteriores análises.

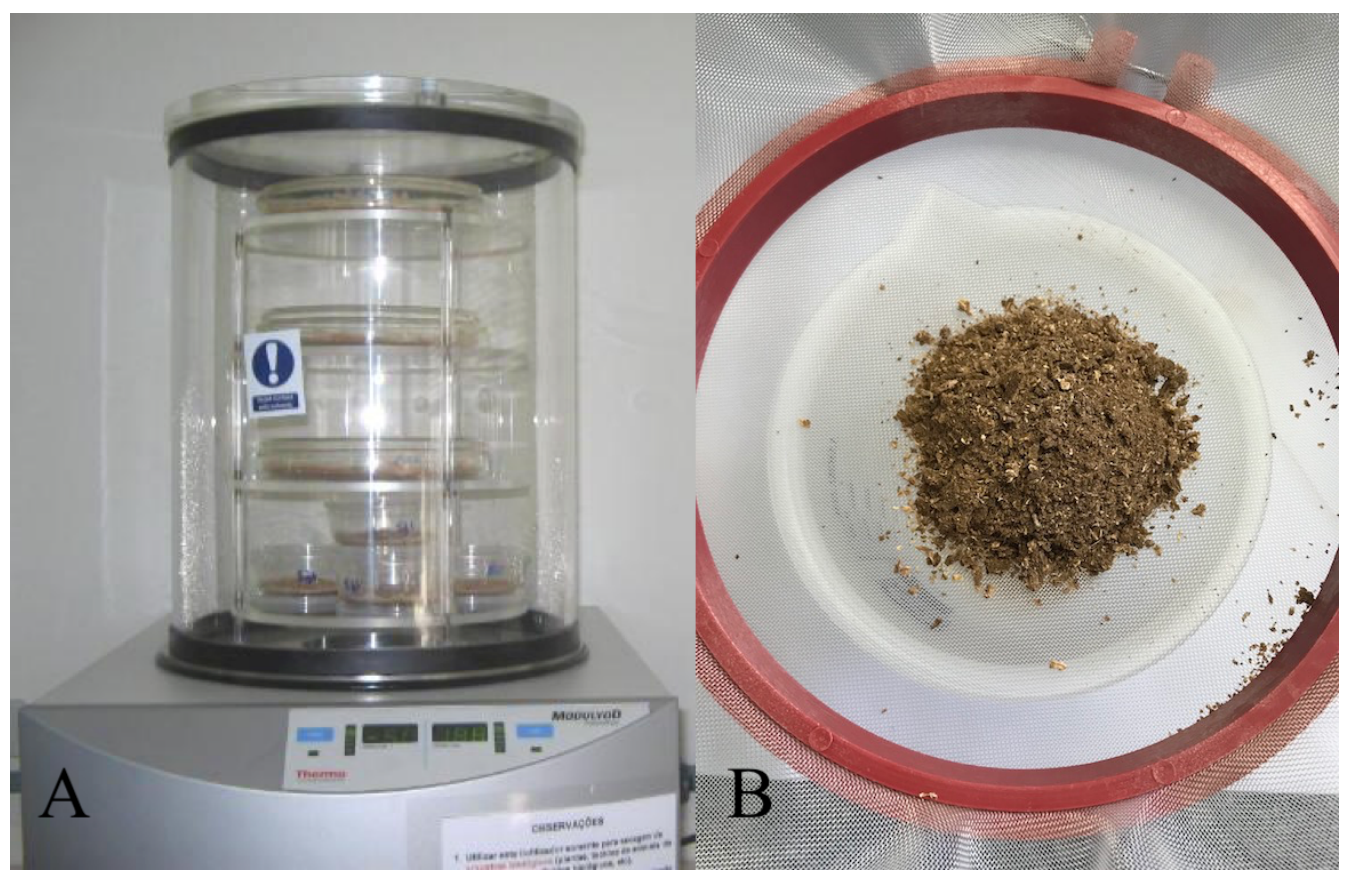

Figura 8. Liofilização das amostras no liofilizador Thermo Electron Corporation, modelo ModulyoD115, no Laboratório de Análises por Ativação Neutrônica (LAN) (A) e peneiração em malha de 80 mesh das amostras liofilizadas (B) (Foto A: Marília G.M.C. Semmler; Foto B: Júlia Camargo).

\subsubsection{Análises}

\subsubsection{Ativação com nêutrons instrumental (INAA)}

Cerca de $150 \mathrm{mg}$ da amostra e padrões dos elementos de interesse foram irradiados simultaneamente no reator nuclear IEA-R1 sob um fluxo de nêutrons térmicos de cerca de $1-3 \times 10^{12} \mathrm{n} \mathrm{cm}^{-2} \mathrm{~s}^{-1}$, por 8 horas. Após um decaimento de 7 dias, amostras e padrões dos elementos foram quantificados (cada padrão por 30 min e cada amostra por $2 \mathrm{~h}$ ) em um espectrômetro de raios gama constituído de um detector de germânio hiperpuro CANBERRA GC2018 HP Ge, acoplado a um analisador multicanal CANBERRA DAS-1000. Nesta primeira medição, obteve-se os teores de As. Após um decaimento de 21 dias, as amostras e padrões dos elementos foram contados novamente por um período de $1 \mathrm{~h}$ para cada padrão e $10 \mathrm{~h}$ para cada amostra. Esta segunda medição forneceu os teores de $\mathrm{Co}, \mathrm{Cr}, \mathrm{Fe}$, Se e $\mathrm{Zn}$. Após as mensurações em espectrômetro, os espectros de raios gama foram coletados e processados utilizando o software Genie 2000, versão 3.1. Finalmente, a concentração de cada elemento foi calculada através de um software específico para cálculos de concentrações de elementos químicos. 


\subsubsection{Espectrometria de absorção atômica (AAS)}

Para a análise dos elementos foram utilizados cerca de $350 \mathrm{mg}$ de amostra, pesados em frascos de Teflon da MARSXPress e foram adicionados $10 \mathrm{~mL}$ de $\mathrm{HNO}_{3}$ concentrado PA da Merck. Em seguida, o frasco foi fechado e deixado em repouso por aproximadamente 24 horas. Para finalizar a digestão, os frascos foram colocados no microondas MARS 6 com o método de digestão para Animal Tissue, com a seguinte programação:

- Stages: 1

- Power: 1030-1800

- Ramp time: 20:00-25:00 min

- Hold time: 15:00 min

- Temperature: $200^{\circ} \mathrm{C}$

Após a digestão no microondas, as amostras foram transferidas para outro frasco de Teflon da SAVILLEX, o volume foi levado a $25,3 \mathrm{~mL}$ com água Milli- ${ }^{\circledR}$ e o conteúdo, homogeneizado.

A detecção de $\mathrm{Hg}$ por espectrometria de absorção atômica com geração de vapor frio (CV AAS) foi realizada no equipamento de CV AAS - FIMS da PerkinElmer (Flow Injection Mercury System). Cerca de $2 \mathrm{~mL}$ da amostra digerida foram transferidos para um tubo Falcon e o volume foi levado a $10 \mathrm{~mL}$ com água Milli-Q ${ }^{\circledR}$ e homogeneizado. A curva de calibração foi preparada através de diluições das soluções estoque de mercúrio $\left(251,05 \mathrm{ng} \mathrm{mL}^{-1}\right)$, sendo utilizados os seguintes pontos: 0,2976; 1,2403; 2,4807; 3,7707; e 4,9614 ng mL ${ }^{-1}$. O volume de injeção da amostra foi de 500 $\mu \mathrm{L}$, o fluxo de argônio de $50 \mathrm{~mL} \mathrm{~min}^{-1}$, o fluxo do carregador de $10 \mathrm{~mL} \mathrm{~min}^{-1}$ e o fluxo redutor de $6 \mathrm{~mL} \mathrm{~min}^{-1}$.

A detecção de $\mathrm{Cd}$ e $\mathrm{Pb}$ por espectrometria de absorção atômica com atomização eletrotérmica (ET AAS) foi realizada no equipamento de AAnalyst 800 da Perkin-Elmer. A curva de calibração foi preparada através de diluições de uma solução estoque (Pb: 1000,00 ng mL ${ }^{-1}$; $\mathrm{Cd}: 2007,5 \mathrm{ng} \mathrm{mL}^{-1}$ ). Para a determinação de $\mathrm{Pb}$, os pontos da curva de calibração foram 2,998; 5,997; 8,995; 11,994; e 14,992 ng mL-1. Para a determinação de $\mathrm{Cd}$, os pontos da curva de calibração foram 1,395; 4,184; e $6,974 \mathrm{ng} \mathrm{mL} \mathrm{mL}^{-1}$. Os softwares dos equipamentos utilizados para estas análises fornecem todos os resultados em ng g ${ }^{-1}$ após a detecção. 


\subsection{Biomarcadores bioquímicos}

A fim de avaliar a exposição dos mexilhões e das ostras a contaminantes, foram determinadas as atividades enzimáticas da etoxiresorufina O-desetilase (EROD), dibenzilfluoresceína (DBF), glutationa S-transferase (GST) e os teores de tióis reduzidos não-proteicos (GSH). Os efeitos dos xenobióticos sobre os organismos foram avaliados através da quantificação de peroxidação lipídica (LPO) e de danos no DNA (strand breaks) e da atividade enzimática das colinesterases (ChE). Todos os biomarcadores bioquímicos foram analisados no leitor de microplaca por multidetecção Synergy ${ }^{\mathrm{TM}}$ HT da BioTek ${ }^{\circledR}$ (Figura 9), de acordo com os protocolos específicos para cada biomarcador.

As análises bioquímicas foram conduzidas no Núcleo de Estudos em Poluição e Ecotoxicologia Aquática (NEPEA) do Instituto de Biociências da Universidade Estadual Paulista "Júlio de Mesquita Filho" (IB-CLP/UNESP), coordenado pelo Prof. Dr. Denis Moledo de Souza Abessa, e com o auxílio da Dra. Luciane Maranho e da Dra. Paloma K. Gusso-Choueri.

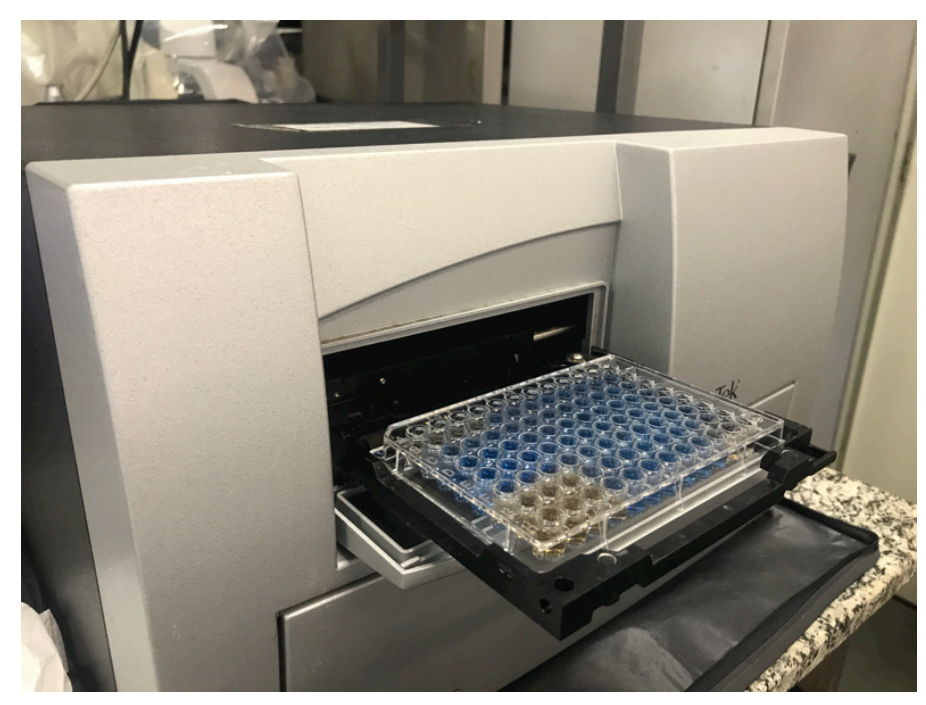

Figura 9. Leitor de microplaca por multidetecção Synergy ${ }^{\mathrm{TM}}$ HT da BioTek ${ }^{\circledR}$, onde foram realizadas as leituras para análise dos biomarcadores bioquímicos (Foto: Júlia Camargo).

\subsubsection{Preparo das amostras}

Após a aclimatação dos organismos, 10 indivíduos foram selecionados, medidos (comprimento e altura da concha) e dissecados para separação das brânquias (Figura 10). Os tecidos dissecados foram pesados e acondicionados em criotubos imersos em nitrogênio até que fossem armazenados em ultrafreezer a $-80^{\circ} \mathrm{C}$ (Figura 11), onde permaneceram até o preparo para as análises bioquímicas. 

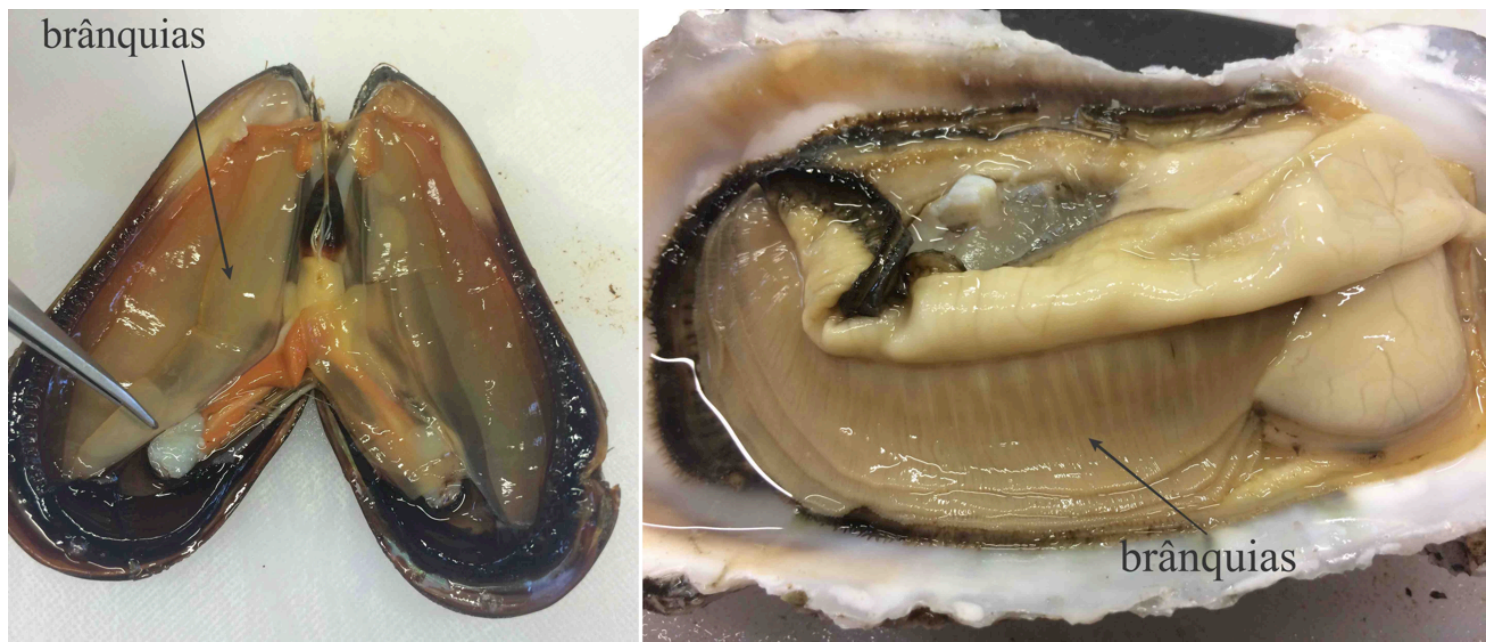

Figura 10. Brânquias do mexilhão Perna perna (esquerda) e da ostra Crassostrea brasiliana (direita), dissecadas para análise dos biomarcadores bioquímicos (Fotos: Júlia Camargo).

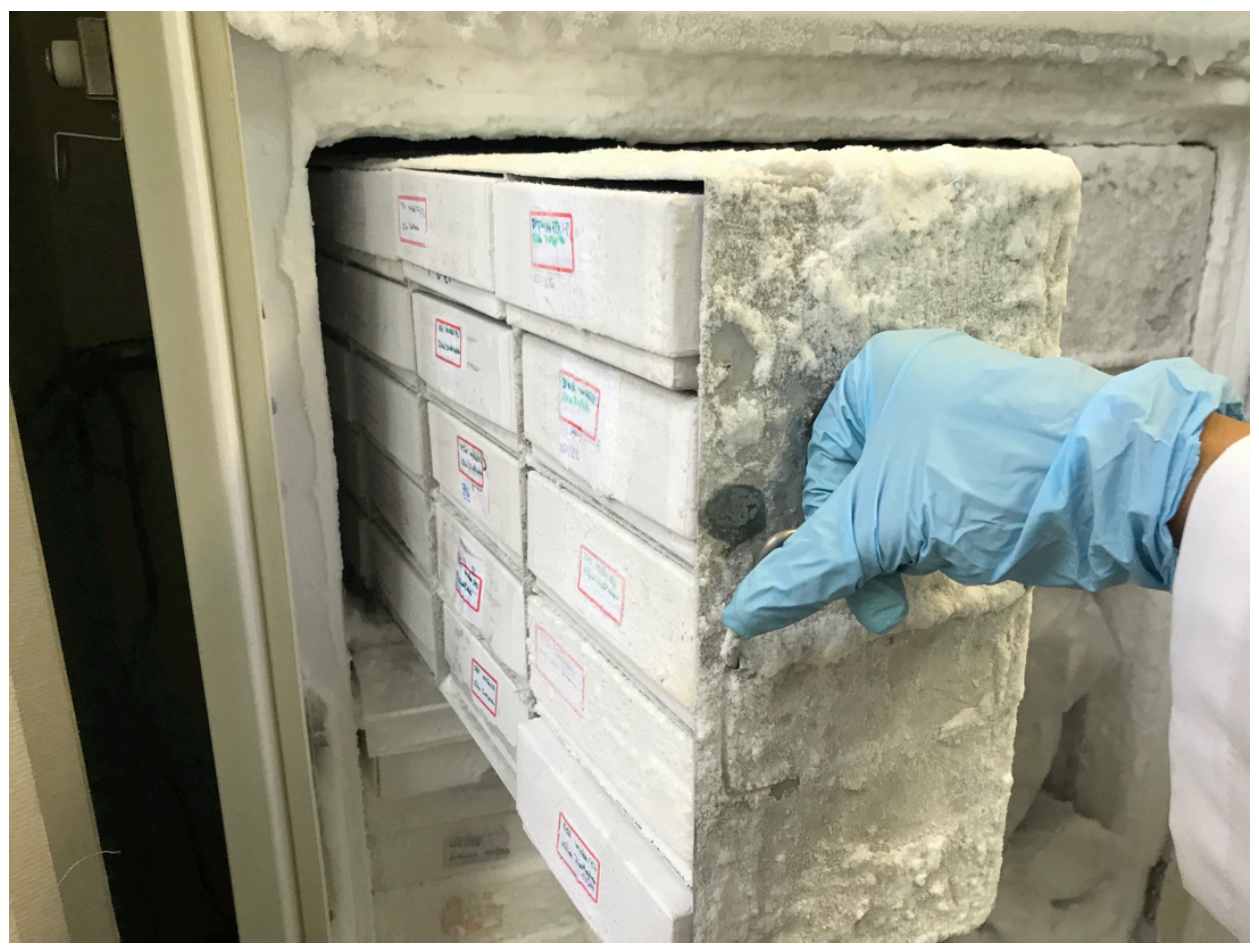

Figura 11. Armazenamento das amostras em ultrafreezer a $-80^{\circ} \mathrm{C}$ (Foto: Júlia Camargo).

Antes das análises bioquímicas, as amostras foram descongeladas em gelo e homogeneizadas individualmente de acordo com Lafontaine et al. (2000), em solução tampão (1:2) com homogeneizador de tecidos. A solução tampão (buffer) para homogeneização constituiu de trizma base $50 \mathrm{mM}\left(121,14 \mathrm{~g} \mathrm{~mol}{ }^{-1}\right)$, ácido etilenodiamino tetra-acético (EDTA) $1 \mathrm{mM}\left(372 \mathrm{~g} \mathrm{~mol}^{-1}\right)$, ditiotreitol (DTT) $1 \mathrm{mM}$ $\left(154,3 \mathrm{~g} \mathrm{~mol}^{-1}\right)$, sacarose $0,5 \mathrm{M}\left(342,3 \mathrm{~g} \mathrm{~mol}^{1}\right)$, cloreto de potássio $(\mathrm{KCl})$ 0,15 M 
(74,55 $\mathrm{g} \mathrm{mol}^{-1}$ ), e fluoreto de fenilmetilsulfonila (PMSF) $30 \mathrm{mM}\left(174,2 \mathrm{~g} \mathrm{~mol}^{-1}\right)$; o $\mathrm{pH}$ da solução final foi ajustado para 7,6 no dia do uso. A partir do homogenato $(\mathrm{FH})$ foram separadas alíquotas para análise de DNA, LPO e PTh (conteúdo de proteína total de FH) em microtubos distintos (Figura 5 e Figura 12). O volume restante foi centrifugado a $15.000 \mathrm{~g}$ a $4^{\circ} \mathrm{C}$ por 20 minutos, obtendo uma fração sobrenadante (S15). Alíquotas de S15 foram separadas em microtubos distintos para as análises de EROD, DBF, GST, GSH, ChE e PTc (conteúdo de proteína total de S15) (Figura 5 e Figura 12). Todas as respostas bioquímicas obtidas foram normalizadas pelo conteúdo de proteína total do extrato correspondente (PTh ou PTc).

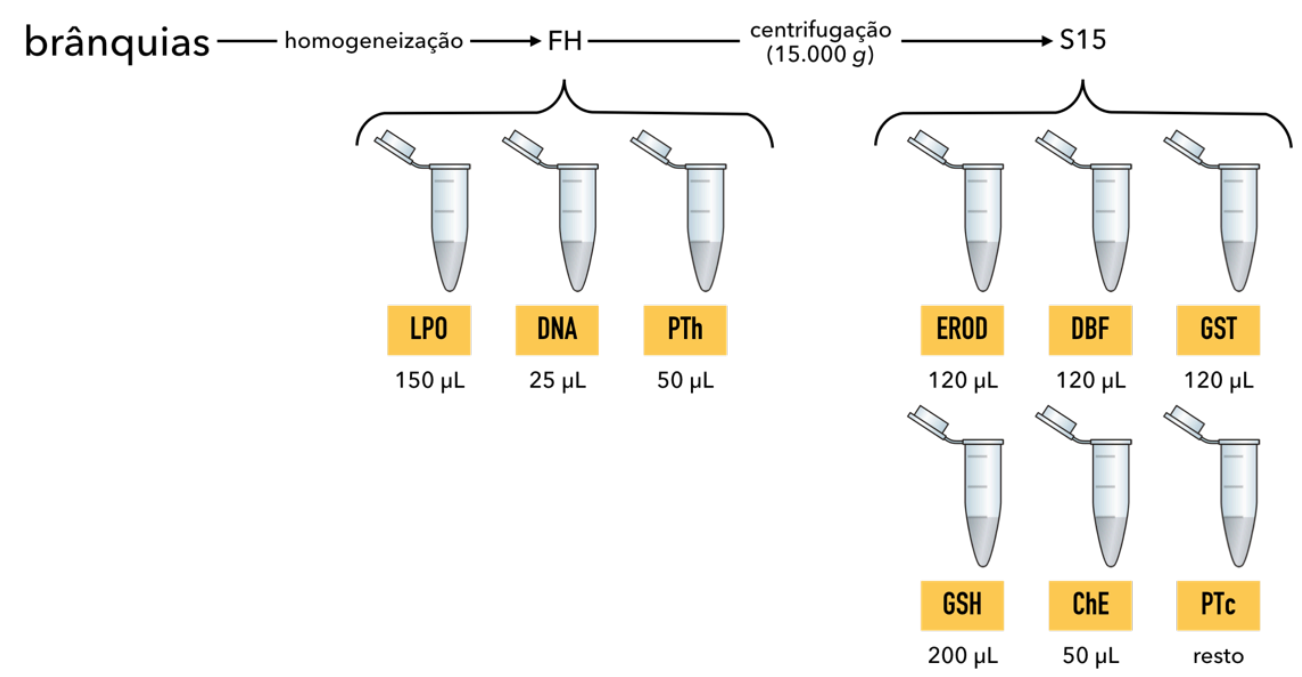

Figura 12. Representação do processo de homogeneização, centrifugação e separação das alíquotas para análise de cada um dos biomarcadores bioquímicos. (FH) fração homogeneizada; (S15) fração sobrenadante; (LPO) peroxidação lipídica; (DNA) danos em DNA; (PTh) conteúdo de proteína total de FH; (EROD) etoxiresorufina O-desetilase; (DBF) dibenzilfluoresceína; (GST) glutationa S-transferase; (ROS) espécies reativas de oxigênio; (GSH) tripeptídeo glutationa; (ChE) colinesterases; (PTc) conteúdo de proteína total de S15.

\subsubsection{Concentração de proteínas totais}

A concentração de proteínas totais foi determinada espectrofotometricamente a $595 \mathrm{~nm}$ através do método de Bradford (1976) para todas as alíquotas separadas (PTh e PTc). As amostras foram diluídas na proporção de 1:10 (i.e. $2 \mu \mathrm{L}$ de amostra para $18 \mu \mathrm{L}$ de buffer), pipetadas diretamente em uma microplaca transparente em duplicata, juntamente com a curva padrão de albumina bovina sérica (BSA, sigla em inglês para bovine serum albumin) e o branco (20 $\mu \mathrm{L}$ de buffer). Em seguida, $180 \mu \mathrm{L}$ do reagente de Bradford foram adicionados a todos os poços da microplaca, a qual foi incubada no escuro por 20 minutos antes de sua leitura no leitor de microplacas. As concentrações utilizadas na curva padrão de BSA foram: 0,$0 ; 0,21 ; 0,42 ; 1,00$; e $1,50 \mathrm{mg} \mathrm{mL}^{-1}$. 


\subsubsection{Biomarcadores de exposição}

\subsubsection{Etoxiresorufina O-desetilase (EROD)}

A atividade da EROD é um indicativo de detoxificação por enzimas relacionadas a famílias do citocromo P450 (CYP450) 1A2, como parte do sistema de oxidases de função mista (MFO), sendo que sua atividade pode ser induzida pela presença de vários compostos como hidrocarbonetos policíclicos aromáticos (HPAs), bifenilas policloradas (PCBs), dioxinas e furanos (van der Oost et al., 2003). Sua atividade foi medida pela velocidade no aumento da fluorescência da resorufina, produto da reação catalisada por este complexo enzimático através do ensaio adaptado de Gagné \& Blaise (1993) e Siebert et al. (2017). Para isso, foram pipetados em uma microplaca escura $50 \mu \mathrm{L}$ das amostras, junto com a curva padrão e o branco $(50 \mu \mathrm{L}$ de buffer), todos em duplicata. Em seguida, $160 \mu \mathrm{L}$ do substrato de etoxiresorufina $50 \mathrm{mM}$ e $10 \mu \mathrm{L}$ de NADPH 4 mM (1142,12 $\left.\mathrm{g} \mathrm{mol}^{-1}\right)$ em solução de $\mathrm{NaOH} \mathrm{0,02} \mathrm{mM} \mathrm{(39,99} \mathrm{g}$ $\mathrm{mol}^{-1}$ ) foram adicionados a todos os poços da microplaca. O seguinte substrato foi preparado no dia do uso: $40 \mu \mathrm{L}$ de solução estoque de etoxiresorufina $5 \mathrm{mM}(241,20 \mathrm{~g}$ $\mathrm{mol}^{-1}$ ) em dimetilsulfóxido (DMSO), diluídos em $40 \mathrm{~mL}$ de tampão trizma base $25 \mathrm{mM}$ $\left(121,14 \mathrm{~g} \mathrm{~mol}^{-1}\right)$ em 1,50 mL de TWEEN 20, avolumado para $500 \mathrm{~mL}$ com água Milli$\mathrm{Q}^{\circledR}$. O pH foi ajustado para 7,4. A curva padrão foi preparada a partir de uma solução estoque de resorufina $5 \mathrm{mM}\left(235,17 \mathrm{~g} \mathrm{~mol}^{-1}\right)$ em DMSO e as concentrações utilizadas foram: 0,$0 ; 0,01 ; 0,025 ; 0,05 ; 0,1 ; 0,15 ; 0,2 \mathrm{mM}$. A quantidade de etoxiresorufina foi obtida fluorimetricamente ( $\lambda_{\text {excitação }} 520 \mathrm{~nm} / \lambda_{\text {emissão }} 590 \mathrm{~nm}$ ) a cada $15 \min$ por $1 \mathrm{~h} \mathrm{a}$ $30^{\circ} \mathrm{C}$. Os resultados estão expressos em nmol $\mathrm{min}^{-1} \mathrm{mg}^{-1}$ proteína total.

\subsubsection{Dibenzilfluoresceína (DBF)}

Assim como a EROD, a DBF pode ser utilizada como substrato para determinação da atividade de enzimas relacionadas a famílias de CYP450 3A4. Esta medição foi realizada de acordo com o método descrito por Gagné et al. (2007), em que foram pipetados $50 \mu \mathrm{L}$ da amostra, da curva padrão e do branco (50 $\mu \mathrm{L}$ de buffer) em uma microplaca escura (todos em duplicata). A todos os poços da microplaca foram adicionados $160 \mu \mathrm{L}$ de substrato de dibenzilfluoresceína e $10 \mu \mathrm{L}$ de NADPH $1 \mathrm{mM}$ $\left(1124,12 \mathrm{~g} \mathrm{~mol}^{-1}\right)$ em solução $\mathrm{NaOH} 0,02 \mathrm{mM}\left(39,99 \mathrm{~g} \mathrm{~mol}^{-1}\right)$. O substrato de dibenzilfluoresceína foi preparado no dia do uso a partir de $51 \mu \mathrm{L}$ da solução estoque de DBF $5 \mathrm{mg} \mathrm{mL}^{-1}$ em acetonitrilo, diluída em 49,94 mL de tampão (mesma composição 
do tampão para EROD). A curva padrão foi preparada a partir de uma solução estoque de fluoresceína $5 \mathrm{mM}\left(376,27 \mathrm{~g} \mathrm{~mol}^{-1}\right)$ em DMSO, utilizando as seguintes concentrações: 0,$0 ; 0,01 ; 0,025 ; 0,05 ; 0,1 \mathrm{mM}$. A quantidade de DBF foi obtida fluorimetricamente $\left(\lambda_{\text {excitação }} 485 \mathrm{~nm} / \lambda_{\text {emissão }} 516 \mathrm{~nm}\right.$ ) a cada $15 \min$ por 45 minutos a $30^{\circ} \mathrm{C}$. Os resultados estão expressos em nmol $\mathrm{min}^{-1} \mathrm{mg}^{-1}$ proteína total.

\subsubsection{Glutationa S-transferase (GST)}

A GST é uma enzima da fase II da detoxificação celular, a qual catalisa a conjugação de compostos eletrofílicos com o tripeptídeo reduzido glutationa (GSH). Esta enzima possui papel crítico na defesa contra danos oxidativos e produtos peroxidativos do DNA e lipídios (George, 1994). A atividade total da GST foi determinada espectrofotometricamente por meio do uso do substrato artificial 1-cloro2,4-dinitrobenzeno (CDNB), sendo obtida a absorbância a $340 \mathrm{~nm}$ a cada 5 min por 30 min. As amostras foram diluídas na proporção de 1:2 (i.e. $25 \mu \mathrm{L}$ de amostra para $25 \mu \mathrm{L}$ de buffer) diretamente em uma microplaca transparente em duplicata, juntamente com o branco (50 $\mu \mathrm{L}$ de buffer). Em seguida, $200 \mu \mathrm{L}$ do meio de reação foram adicionados a todos os poços da microplaca, prosseguindo imediatamente à leitura em espectrofotômetro. O meio de reação foi preparado no dia de uso a partir da seguinte composição: HEPES-NaOH $10 \mathrm{mM}\left(360,29 \mathrm{~g} \mathrm{~mol}^{-1}\right)$, cloreto de sódio $(\mathrm{NaCl})$ 0,125 M $\left(58,44 \mathrm{~g} \mathrm{~mol}^{-1}\right)$, 1-cloro-2,4-dinitrobenzeno (CDNB) $1 \mathrm{mM}\left(202,55 \mathrm{~g} \mathrm{~mol}^{-1}\right)$, e Lglutationa reduzida $1 \mathrm{mM}\left(307,32 \mathrm{~g} \mathrm{~mol}^{-1}\right)$; o $\mathrm{pH}$ foi ajustado para 8,9. Os resultados estão expressos em nmol $\mathrm{min}^{-1} \mathrm{mg}^{-1}$ proteína total. O protocolo utilizado foi adaptado de McFarland et al. (1999).

\subsubsection{Tióis reduzidos não-proteicos $(\mathrm{GSH})$}

Em geral, a GSH desempenha um papel fundamental na defesa celular e serve como um reservatório para o aminoácido cisteína, além de fornecer substrato para a ação das enzimas glutationa S-transferase e glutationa peroxidase. A depleção de GSH conduz à morte celular e tem sido documentada em muitas condições degenerativas (Kovačević et al., 2008). Para a determinação dos níveis de GSH, $50 \mu \mathrm{L}$ de ácido tricloroacético (TCA) 50\% foram adicionados a $200 \mu \mathrm{L}$ de S15, misturados e centrifugados a $5.000 \mathrm{~g} \mathrm{a} 4^{\circ} \mathrm{C}$ por 10 minutos. Para o branco, $200 \mu \mathrm{L}$ de buffer sofreram o mesmo tratamento. Em microplacas transparentes, foram pipetados $50 \mu \mathrm{L}$ deste centrifugado, juntamente com a curva padrão e o branco, todos em duplicata. A todos 
os poços da microplaca foram adicionados $230 \mu \mathrm{L}$ de solução tampão trizma base $0,4 \mathrm{M}$ $\left(121,14 \mathrm{~g} \mathrm{~mol}^{-1}\right)$ e $20 \mu \mathrm{L}$ do substrato artificial 5,5'-ditiobis-2-nitrobenzoico (DTNB) 2,5 mM (393,3 $\left.\mathrm{g} \mathrm{mol}^{-1}\right)$. Antes da medição da absorbância a $415 \mathrm{~nm}$, a microplaca foi incubada a temperatura ambiente por $10 \mathrm{~min}$ (Sedlak \& Lindsay, 1968). As concentrações utilizadas na curva padrão de GSH foram: 0,0; 5,0;10,0;20,0;40,0; 80,0; 160,0; e 320,0 $\mu \mathrm{M}$. Os resultados estão expressos em nmol mg ${ }^{-1}$ proteína total.

\subsubsection{Biomarcadores de efeito}

\subsubsection{Danos em DNA (strand breaks)}

Muitos xenobióticos são capazes de gerar danos ao material genético, sendo a estimativa de danos em DNA um bom parâmetro para avaliar os efeitos da contaminação ambiental sobre a biota (Everaarts \& Sarkar, 1996). Os danos em DNA foram avaliados pelo ensaio de precipitação alcalina, em que vestígios de DNA (strand breaks) são quantificados utilizando fluorescência (Gagné \& Blaise, 1993).

De acordo com o método, $200 \mu \mathrm{L}$ de uma solução de dodecil sulfato de sódio (DSS) $2 \%$ foram adicionados a $25 \mu \mathrm{L}$ de amostra em microtubo e misturados por inversão. A solução de DSS 2\% foi preparada com ácido etilenodiamino tetra-acético (EDTA) $10 \mathrm{mM}\left(292,20 \mathrm{~g} \mathrm{~mol}^{-1}\right)$, trizma base $10 \mathrm{mM}\left(121,14 \mathrm{~g} \mathrm{~mol}^{-1}\right)$, hidróxido de sódio $(\mathrm{NaOH}) 40 \mathrm{mM}\left(40,0 \mathrm{~g} \mathrm{~mol}^{-1}\right)$ e DSS 2\%. Em seguida, foram adicionados $200 \mu \mathrm{L}$ de uma solução de cloreto de potássio $(\mathrm{KCl}) 12 \mathrm{mM}\left(74,56 \mathrm{~g} \mathrm{~mol}^{-1}\right)$, os microtubos foram misturados por inversão e incubados em banho-maria a $60^{\circ} \mathrm{C}$ por 10 minutos. Após a incubação, os microtubos foram novamente misturados por inversão e incubados em geladeira a $4^{\circ} \mathrm{C}$ por 30 minutos. Ao final deste período, as amostras foram centrifugadas a $8.000 \mathrm{~g}$ a $4^{\circ} \mathrm{C}$ por 5 minutos. Em microplaca escura, foram pipetados 50 $\mu \mathrm{L}$ do sobrenadante de cada amostra, da curva padrão e do branco (buffer) em duplicata. Foram pipetados $150 \mu \mathrm{L}$ do reagente Hoescht em toda a microplaca e, posteriormente, foi realizada a leitura em fluorímetro ( $\lambda_{\text {excitação }} 360 \mathrm{~nm} / \lambda_{\text {emissão }} 460 \mathrm{~nm}$ ). A curva padrão foi preparada a partir de uma solução de esperma de salmão em TEIX (trizma base $10 \mathrm{mM}$ e EDTA $1 \mathrm{mM}$ ), sendo que as concentrações utilizadas foram: 0,$00 ; 0,455 ; 0,91 ; 2,27 ; 4,55 ; 9,09 ; 11,36 ;$ e $13,63 \mu \mathrm{g} \mathrm{mL} \mathrm{m}^{-1}$. Os resultados estão expressos em $\mu \mathrm{g}$ DNA $\mathrm{mg}^{-1}$ proteína total.

\subsubsection{Peroxidação lipídica (LPO)}


A oxidação de ácidos graxos polinsaturados é uma importante consequência do estresse oxidativo (van der Oost et al., 2003). O método utilizado para analisar os níveis de peroxidação lipídica foi descrito por Wills (1987), em que produtos da peroxidação são quantificados por fluorimetria. Para isso, $300 \mu \mathrm{L}$ de TCA $10 \%$ em $\mathrm{FeSO}_{4} 1 \mathrm{mM}$ $\left(270,02 \mathrm{~g} \mathrm{~mol}^{-1}\right)$ e $150 \mu \mathrm{L}$ de ácido tiobarbitúrico (TBA) $0,67 \%$ foram adicionados a $150 \mu \mathrm{L}$ de amostra em microtubo e misturados por inversão. As amostras foram incubadas em banho-maria a $70^{\circ} \mathrm{C}$ por 10 minutos. Em microplaca escura, foram pipetados $200 \mu \mathrm{L}$ do sobrenadante de cada amostra e da curva padrão em duplicata, sendo lidas em fluorímetro $\left(\lambda_{\text {ex }} 530 \mathrm{~nm} / \lambda_{\mathrm{em}} 590 \mathrm{~nm}\right)$. A curva padrão foi preparada a partir de uma solução de tetrametoxipropano (TMP) 0,001\% $\left(164,20 \mathrm{~g} \mathrm{~mol}^{-1}\right) \mathrm{em} \mathrm{HCl}$ $0,1 \mathrm{M}\left(36,46 \mathrm{~g} \mathrm{~mol}^{-1}\right)$, sendo que as concentrações utilizadas foram: 0,0;0,6;1,5;3,0; 4,$0 ; 6,0 ; 10,0 ;$ e $15,0 \mu \mathrm{M}$. Os resultados estão expressos como substâncias reativas do ácido tiobarbitúrico (TBARS), em pmol TBARS $\mathrm{mg}^{-1}$ proteína total.

\subsubsection{Colinesterases (ChE)}

As ChEs são enzimas responsáveis pela hidrólise de ésteres de colina (e.g. o neurotransmissor acetilcolina) nas fendas sinápticas durante a transmissão colinérgica, prevenindo a ativação nervosa contínua, sendo de fundamental importância para o bom funcionamento dos sistemas sensoriais e neuromusculares do organismo (Bocquené et al., 1997; Freire et al., 2008; Payne et al., 1996). A determinação de sua atividade foi realizada por meio do ensaio descrito por Ellman et al. (1961) e adaptado por Guilhermino et al. (1996), através de espectrofotometria. Assim, $20 \mu \mathrm{L}$ de amostra e do branco (buffer) foram pipetados em microplaca transparente em duplicata. Em seguida, $130 \mu \mathrm{L}$ de DTNB 0,75 mM (393,3 $\left.\mathrm{g} \mathrm{mol}^{-1}\right)$ e $50 \mu \mathrm{L}$ de iodeto de acetilcolina $9 \mathrm{mM}$ $\left(273,11 \mathrm{~g} \mathrm{~mol}^{-1}\right)$ foram pipetados em toda a microplaca, sendo feitas leituras a $405 \mathrm{~nm}$ a cada 1 minuto por 7 minutos. Os resultados estão expressos em nmol tiol $\mathrm{min}^{-1} \mathrm{mg}^{-1}$ proteína total.

\subsection{Biomarcador fisiológico}

A estabilidade da membrana lisossomal dos hemócitos dos bivalves foi avaliada por meio do ensaio de tempo de retenção do vermelho neutro (NRRT, do inglês neutral red retention time), segundo metodologia descrita por Lowe et al. (1995). Este ensaio se baseia na capacidade dos lisossomos de assimilar e reter o corante vermelho neutro (NR) ao longo do tempo que, quando comprometida devido a danos à 
membrana lisossomal, reflete o efluxo de conteúdos lisossomais para o citosol. Células que já tenham sido expostas a poluentes ambientais serão afetadas pelo NR mais rapidamente que aquelas não expostas. Ou seja, quanto mais rápido as células apresentam NR no citosol ou alterações no formato das células, maior é o grau de estresse ambiental a que elas foram expostas previamente. Este ensaio tem alta sensibilidade, sendo um bom indicador de danos celulares produzidos por exposição à contaminação.

\subsubsection{Preparo das soluções}

\subsubsection{Solução fisiológica}

Utilizada para diluir a hemolinfa extraída dos organismos, a solução fisiológica foi preparada até um dia antes da realização do experimento. Sua composição foi: HEPES $20 \mathrm{mM}\left(238,30 \mathrm{~g} \mathrm{~mol}^{-1}\right)$, cloreto de sódio $(\mathrm{NaCl}) 436 \mathrm{mM}\left(58,44 \mathrm{~g} \mathrm{~mol}^{-1}\right)$, sulfato de magnésio $\left(\mathrm{MgSO}_{4}\right) 53 \mathrm{mM}\left(120,36 \mathrm{~g} \mathrm{~mol}^{-1}\right)$, cloreto de potássio $(\mathrm{KCl}) 10$ $\mathrm{mM}\left(74,55 \mathrm{~g} \mathrm{~mol}^{-1}\right)$, cloreto de cálcio $\left(\mathrm{CaCl}_{2}\right) 10 \mathrm{mM}\left(110,98 \mathrm{~g} \mathrm{~mol}^{-1}\right) . \mathrm{O} \mathrm{pH}$ foi ajustado para 7,36 no dia do uso.

\subsubsection{Solução de vermelho neutro}

Para o preparo da solução estoque de vermelho neutro foram diluídos cerca de $28,8 \mathrm{mg}$ do corante em $1 \mathrm{~mL}$ de DMSO e a solução de trabalho foi preparada pela diluição de $10 \mu \mathrm{L}$ da solução estoque em $5 \mathrm{~mL}$ de solução fisiológica.

\subsubsection{Preparo das amostras}

Após a aclimatação dos organismos, 15 indivíduos foram selecionados, medidos (comprimento e altura da concha) e amostras de hemolinfa foram extraídas de cada organismo. As valvas foram cuidadosamente separadas e, com uma seringa hipodérmica contendo $0,5 \mathrm{~mL}$ da solução fisiológica, foi extraído $0,5 \mathrm{~mL}$ de hemolinfa do músculo adutor posterior (Figura 13). 


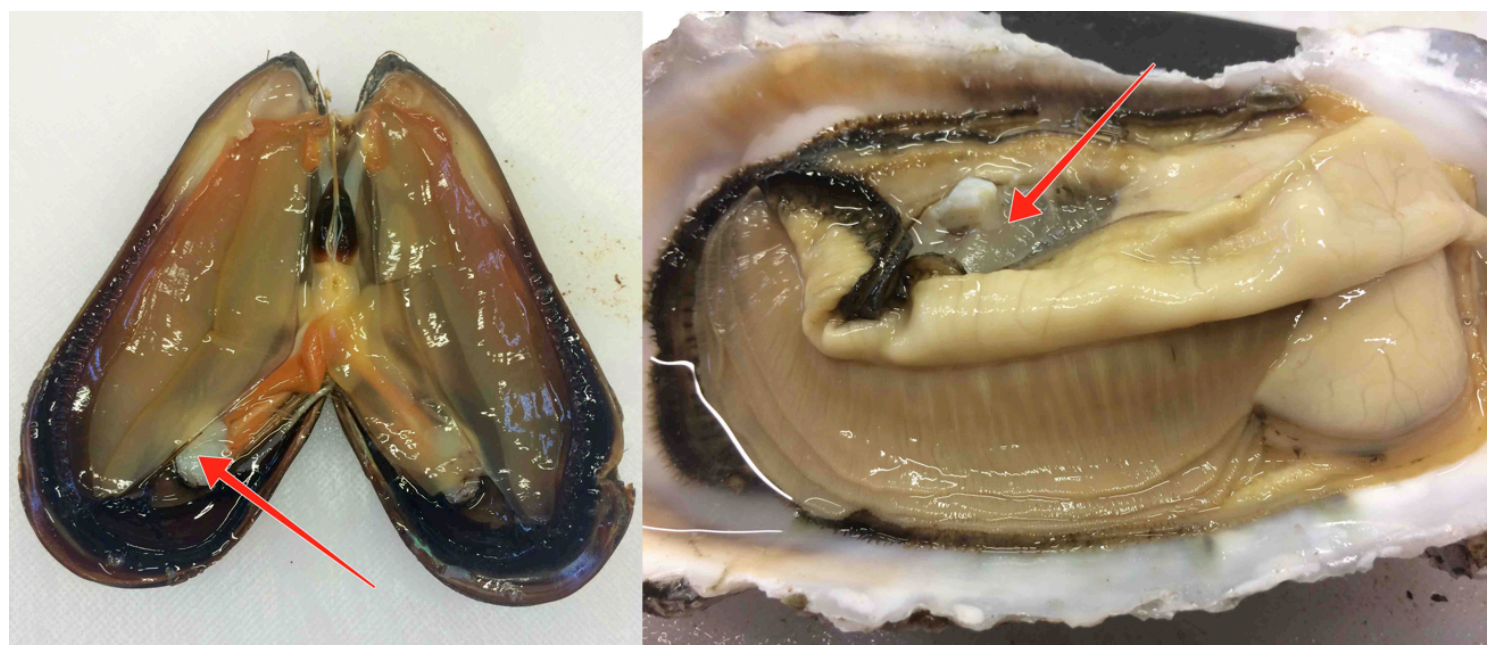

Figura 13. Músculos adutores posteriores (seta vermelha) do mexilhão Perna perna (esquerda) e da ostra Crassostrea brasiliana (direita), através do qual a agulha da seringa hipodérmica é inserida para extração da hemolinfa (Fotos: Júlia Camargo).

O conteúdo da seringa foi transferido para um microtubo de $2 \mathrm{~mL}$. Após, 15 min, os microtubos foram gentilmente invertidos e $40 \mu \mathrm{L}$ desta solução de células sanguíneas foram pipetados sobre uma lâmina de microscópio (Figura 14). As lâminas foram incubadas por 15 min em uma câmara úmida à prova de luz e, em seguida, foi retirado o excesso de solução e aplicados $40 \mu \mathrm{L}$ da solução de trabalho de vermelho neutro.

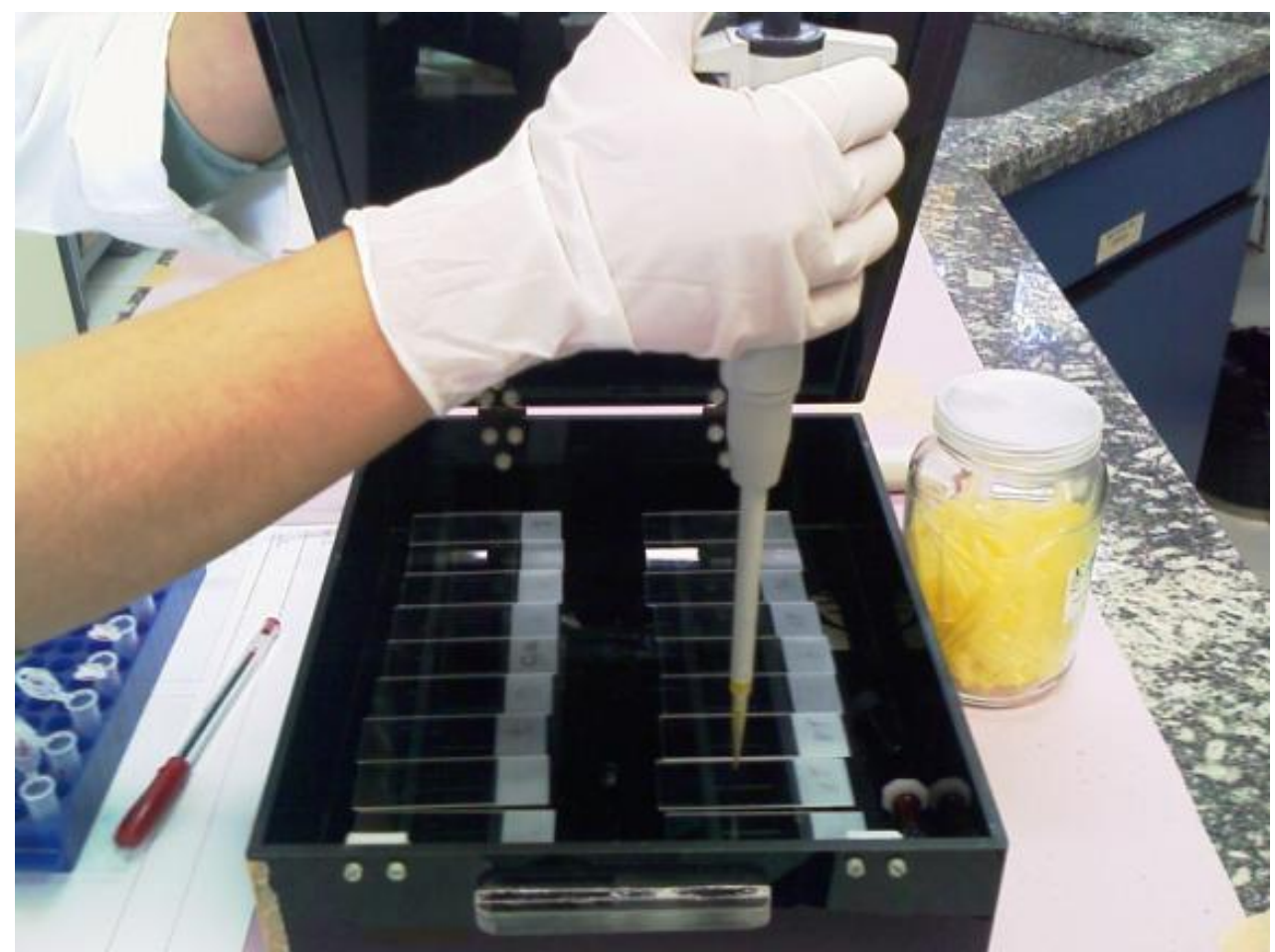

Figura 14. Aplicação da solução de células sanguíneas às lâminas de microscópio dispostas no interior de uma câmara úmida à prova de luz (Foto: Marília G.M.C. Semmler). 


\subsubsection{Ensaio de tempo de retenção do vermelho neutro}

A partir da montagem das lâminas com as células da hemolinfa tratadas com o vermelho neutro, foi possível prosseguir à leitura sistemática destas lâminas em microscópio óptico $(400 \mathrm{x})$ em intervalos de $15 \mathrm{~min}$ durante a primeira hora $\mathrm{e}$, posteriormente, a cada $30 \mathrm{~min}$, a fim de determinar em quanto tempo o corante assimilado pelos lisossomos extravasou para o citosol (Figura 15). O teste foi encerrado quando mais de 50\% das células exibiram vazamento lisossomal e/ou anormalidades estruturais (Tabela 3) e o tempo de retenção foi registrado para cada organismo.

Tabela 3. Critérios analisados na observação das lâminas com hemócitos tratados com vermelho neutro. Modificado de Pereira (2008).

\begin{tabular}{lcc}
\hline \multicolumn{1}{c}{ Critério } & Células saudáveis & Células estressadas \\
\hline Formato das células & arredondadas & irregulares \\
Tamanho das células & grandes & reduzidas \\
Número de lisossomos & abundante & reduzido \\
Tamanho dos lisossomos & pequenos & alargados \\
Cor dos lisossomos & vermelho pálido, & vermelho ou rosa escuro, \\
Pseudópodes & rosado & alaranjado, marrom \\
Extravasamento de conteúdo celular & ausente & presente \\
\hline
\end{tabular}

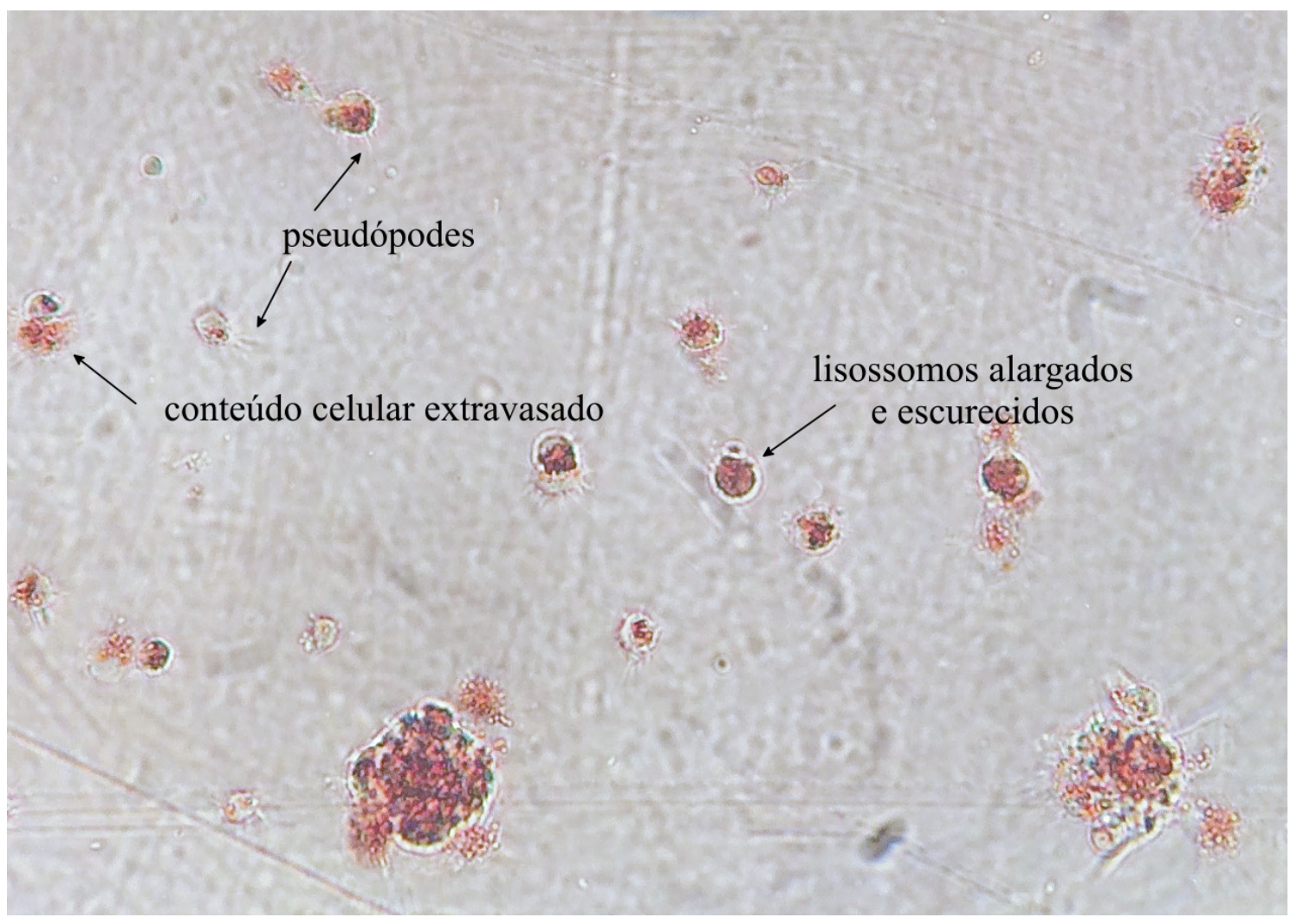

Figura 15. Hemócitos tratados com corante vermelho neutro observados sob microscópio óptico (400x). As setas pretas indicam exemplos de alguns dos critérios analisados (Foto: Júlia Camargo). 


\subsection{Análise dos resultados}

Foram verificadas a normalidade e homocedasticidade dos dados obtidos através dos testes de Shapiro-Wilk e de Levene, respectivamente. Posteriormente, outliers foram identificados através do teste de Grubbs (https://www.graphpad.com/quickcalcs/grubbs1/). A partir disso, os resultados médios de cada ponto de coleta em cada estação do ano foram comparados utilizando análise de variância de duas vias (ANOVA), com nível de significância $\alpha<0,05$ (Zar, 1996). Os parâmetros de comparação foram os pontos de coleta e as estações do ano. Para comparações múltiplas pairwise entre os pontos de coleta, foi realizado o teste post hoc de Dunnett. Para comparações múltiplas entre as estações do ano foram realizados o teste de Šidák quando da comparação entre duas estações (i.e. primavera/2016 e outono/2017), ou o teste de Tukey, quando da comparação entre mais estações (i.e. primavera/2008, verão/2009 e inverno/2009) (Abdi, 2007; McHugh, 2011).

Além disso, os resultados das análises química, bioquímica e fisiológica foram integradas através de uma análise de componentes principais (PCA, sigla em inglês para principal components analysis), visando a avaliação da exposição e dos efeitos de contaminantes em diferentes níveis de organização biológica. Foram extraídos os fatores principais utilizando-se o critério de Kaiser, que determina a inclusão de autovalores (eigenvalues) maiores que 1, e as variáveis foram selecionadas quando os loadings nos autovetores (eigenvectors) foram maiores de 0,50 (Mardia et al., 1979). 


\section{Resultados}

\subsection{Morfometria}

A relação comprimento-altura das conchas dos mexilhões e ostras utilizados nas diferentes análises (bioacumulação de metais, biomarcadores bioquímicos ou biomarcador fisiológico) está apresentada na Figura 16, de acordo com a análise a que os organismos foram destinados.

O comprimento médio entre todos os mexilhões analisados foi de $6,15 \mathrm{~cm}$, sendo o comprimento mínimo de $3,6 \mathrm{~cm}$ e o comprimento máximo de 9,7 cm. Em relação à altura, o valor médio foi de 2,97 cm, variando entre 1,8 e 5,1 cm (Tabela 4). No que diz respeito ao tamanho das conchas de todas as ostras analisadas, o comprimento médio foi de $9,08 \mathrm{~cm}$, variando de 4,2 a 17,9 cm; enquanto a altura média foi de 6,06 cm, com altura mínima de $2,8 \mathrm{~cm}$ e máxima de $10,9 \mathrm{~cm}$ (Tabela 4). As medidas de todos os organismos utilizados encontram-se no Apêndice A.

Tabela 4. Comprimento $(\mathrm{cm})$ e altura $(\mathrm{cm})$ médios, mínimos e máximos das conchas dos mexilhões $P$. perna e das ostras C. brasiliana utilizados nas análises de bioacumulação de metais, biomarcadores bioquímicos e biomarcador fisiológico.

\begin{tabular}{llcccc}
\hline & & \multicolumn{2}{c}{ Mexilhões P. perna } & \multicolumn{2}{c}{ Ostras C. brasiliana } \\
& & Comp. $(\mathbf{c m})$ & Alt. $(\mathbf{c m})$ & Comp. $(\mathbf{c m})$ & Alt. $(\mathbf{c m})$ \\
\hline Metais & média & 5,58 & 2,75 & 8,92 & 5,95 \\
& mínimo & 3,60 & 1,80 & 4,90 & 3,40 \\
& máximo & 8,90 & 4,30 & 14,60 & 10,00 \\
\hline Biomarcadores & média & 7,38 & 3,43 & 8,39 & 5,81 \\
bioquímicos & mínimo & 4,80 & 2,50 & 4,20 & 2,80 \\
& máximo & 9,70 & 5,10 & 15,00 & 10,90 \\
\hline Biomarcador & média & 7,06 & 3,38 & 10,97 & 7,00 \\
fisiológico & mínimo & 4,90 & 2,50 & 7,90 & 4,30 \\
& máximo & 9,40 & 4,80 & 17,90 & 10,00 \\
\hline Total & média & 6,15 & 2,97 & 9,08 & 6,06 \\
& mínimo & 3,60 & 1,80 & 4,20 & 2,80 \\
& máximo & 9,70 & 5,10 & 17,90 & 10,90 \\
\hline
\end{tabular}



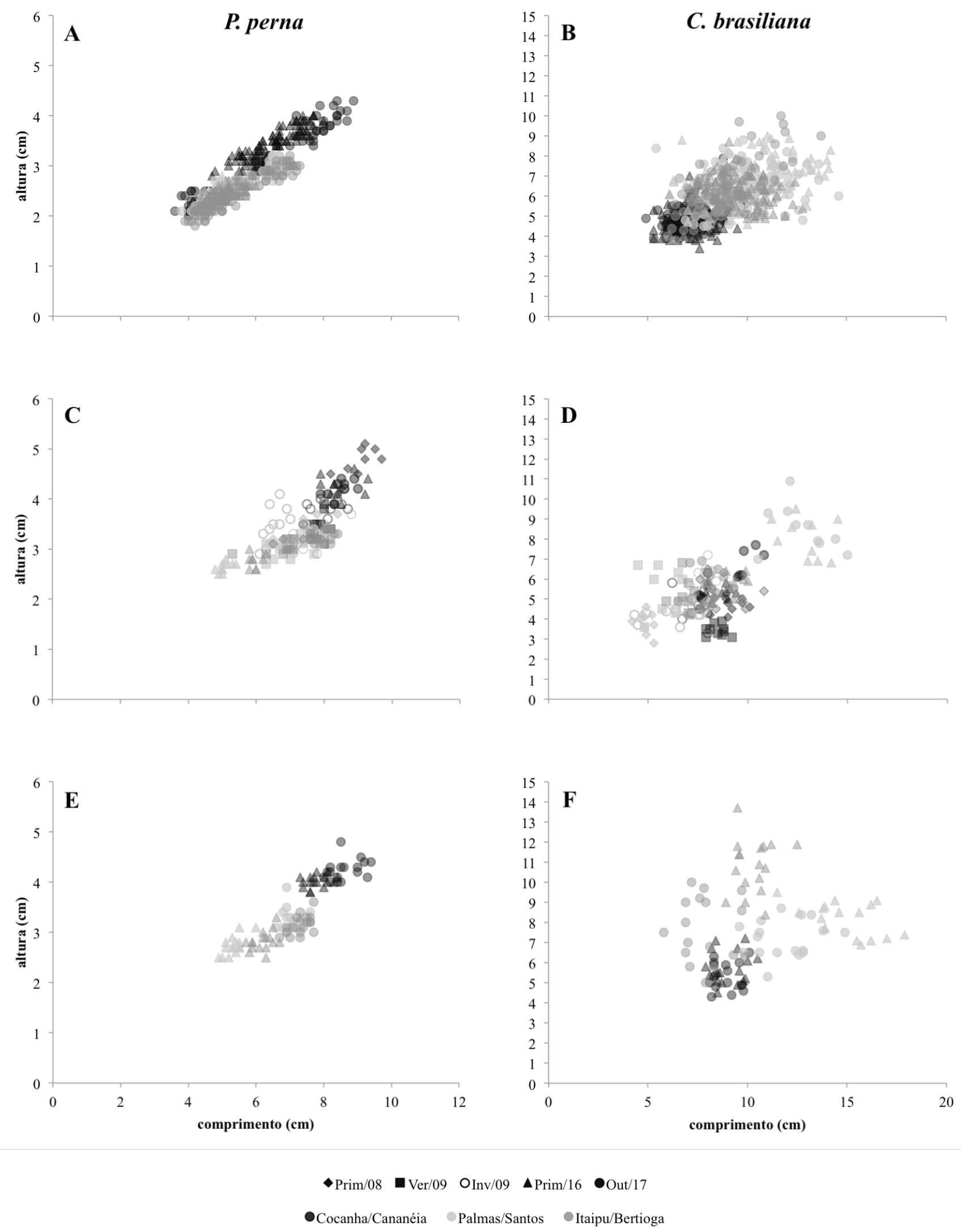

Figura 16. Relação comprimento-altura das conchas de mexilhões $P$. perna (A, C, E) e ostras $C$. brasiliana (B, D, F) utilizados para análises de bioacumulação de metais (A, B), biomarcadores bioquímicos (C, D) e biomarcador fisiológico (E, F). Pontos de coleta: Cocanha e Cananéia (preto); Palmas e Santos (cinza claro); Itaipu e Bertioga (cinza escuro). Estações do ano: primavera/2008 ( $\bullet$ );

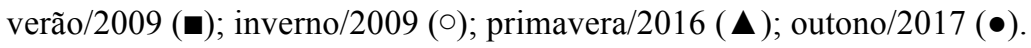




\subsection{Campanha de 2008/09}

\subsubsection{Bioacumulação de metais}

Os dados das análises de bioacumulação de metais em tecidos de mexilhões coletados durante a primavera de 2008, o verão de 2009 e o inverno de 2009 estão apresentados na Tabela 5 e na Figura 17. Os dados das análises de bioacumulação de metais em tecidos de ostras coletadas primavera de 2008, o verão de 2009 e o inverno de 2009 estão apresentados na Tabela 6 e na Figura 18. Estes dados foram produzidos durante o trabalho de pós-doutorado da pesquisadora Dra. Marília G. M. C. Semmler (LAN/IPEN/CNEN-SP) e publicados em Catharino et al. (2012) e Catharino et al. (2015).

\subsubsection{Biomarcadores bioquímicos}

As respostas bioquímicas dos biomarcadores analisados nos tecidos branquiais de mexilhões coletados durante a primavera de 2008, o verão de 2009 e o inverno de 2009 nos diferentes pontos de coleta estão ilustradas na Tabela 7 e na Figura 19. As respostas bioquímicas dos biomarcadores analisados nos tecidos branquiais de ostras coletadas durante a primavera de 2008, o verão de 2009 e o inverno de 2009 nos diferentes pontos de coleta estão apresentadas na Tabela 8 e na Figura 20. 


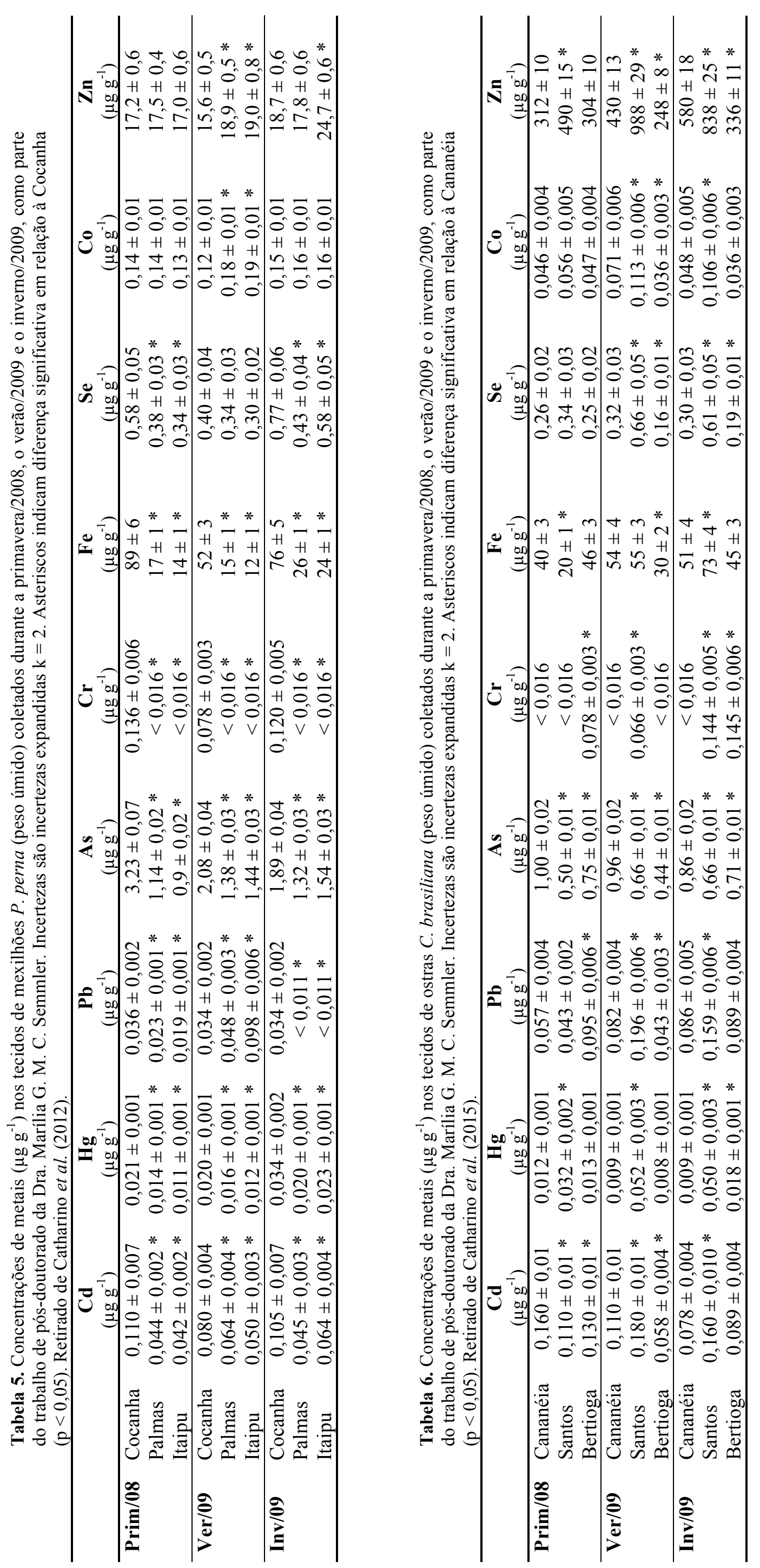



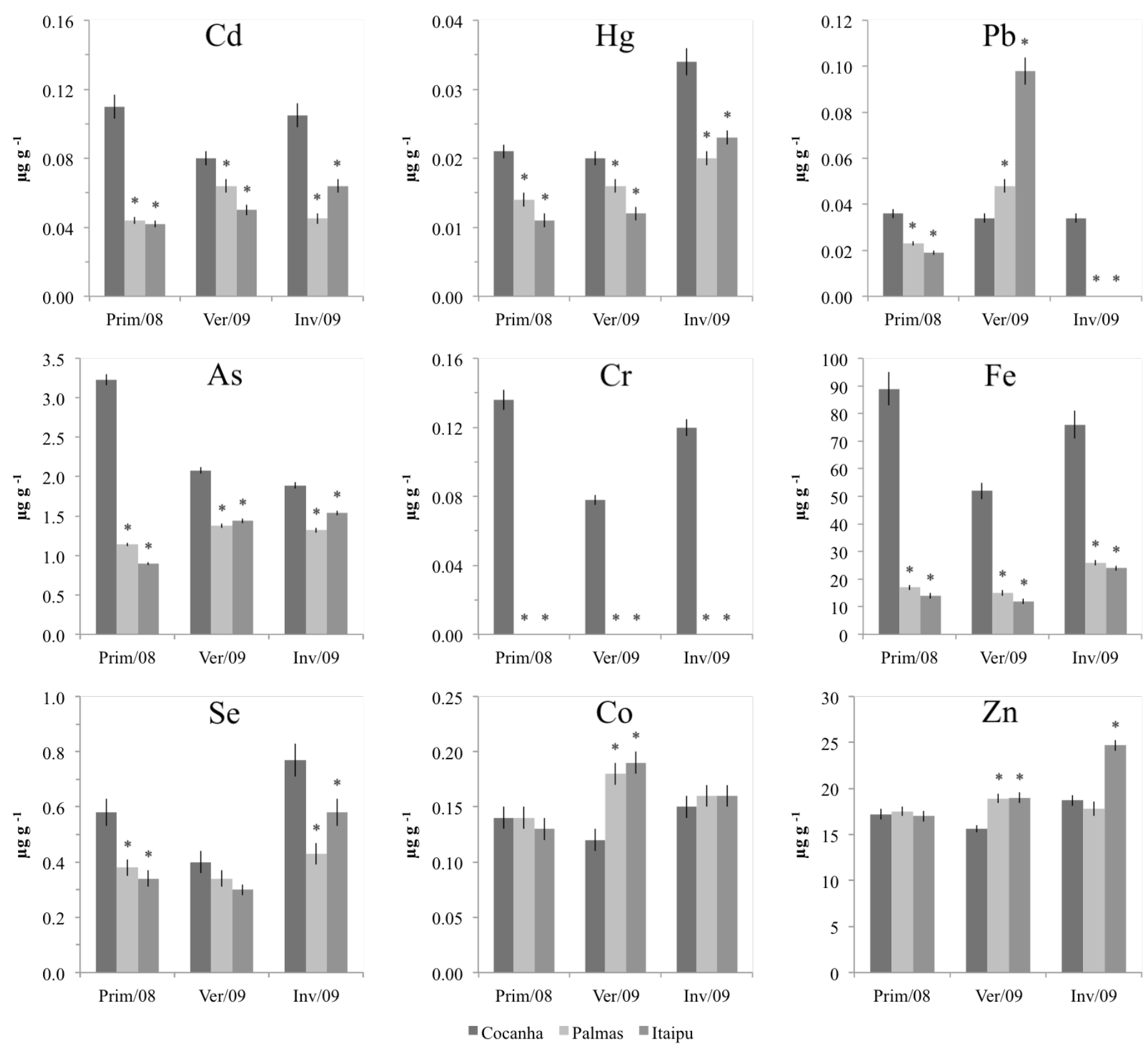

Figura 17. Concentrações de metais $\left(\mu \mathrm{g} \mathrm{g}^{-1}\right)$ nos tecidos de mexilhões $P$. perna (peso úmido) coletados durante a primavera/2008, o verão/2009 e o inverno/2009, como parte do trabalho de pós-doutorado da Dra. Marília G. M. C. Semmler. Incertezas são incertezas expandidas k=2. Asteriscos indicam diferença significativa em relação à Cocanha $(\mathrm{p}<0,05)$. 

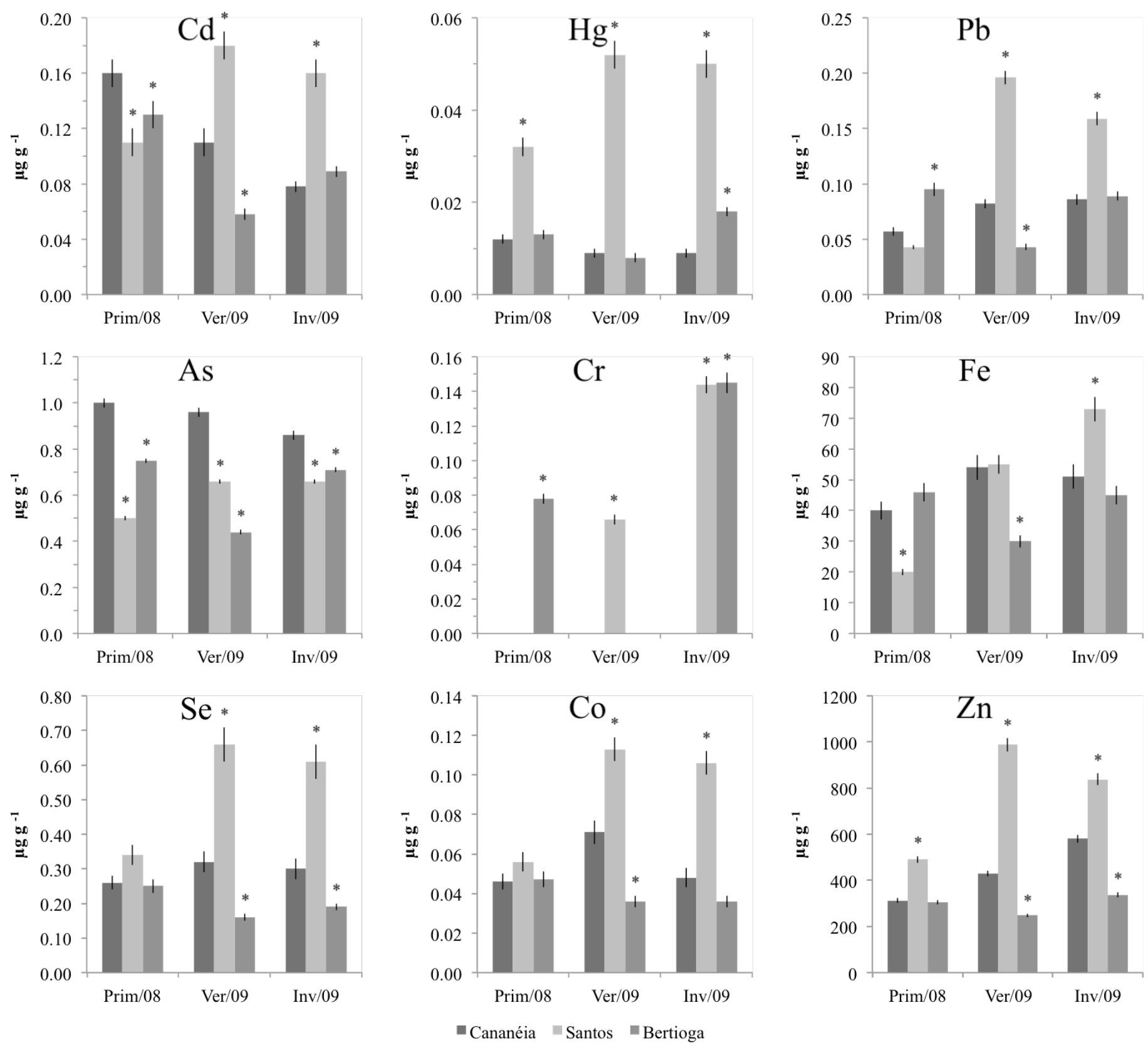

Figura 18. Concentrações de metais $\left(\mu \mathrm{g} \mathrm{g}^{-1}\right)$ nos tecidos de ostras C. brasiliana (peso úmido) coletadas durante a primavera/2008, o verão/2009 e o inverno/2009, como parte do trabalho de pós-doutorado da Dra. Marília G. M. C. Semmler. Incertezas são incertezas expandidas $k=2$. Asteriscos indicam diferença significativa em relação a Cananéia $(\mathrm{p}<0,05)$. 


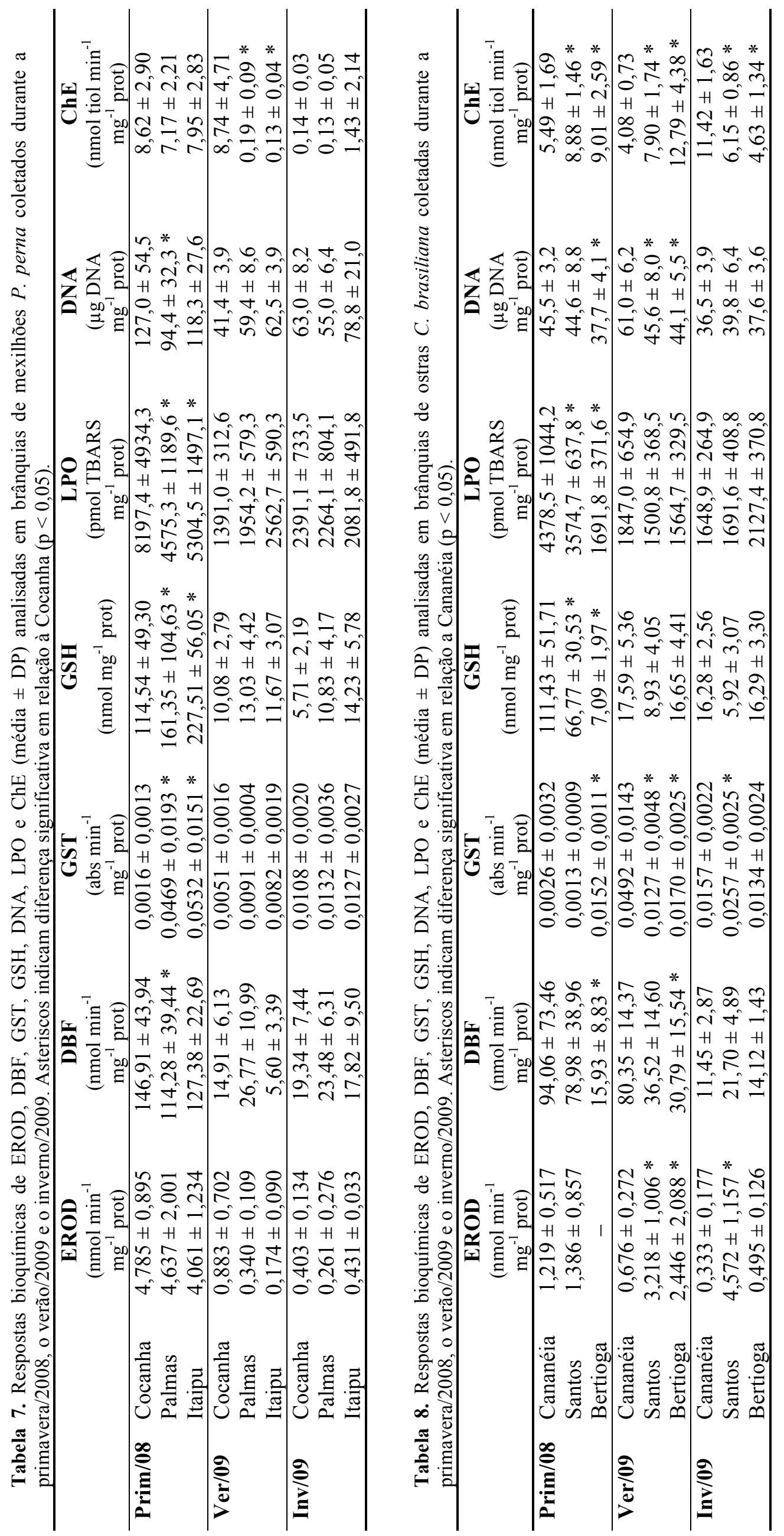



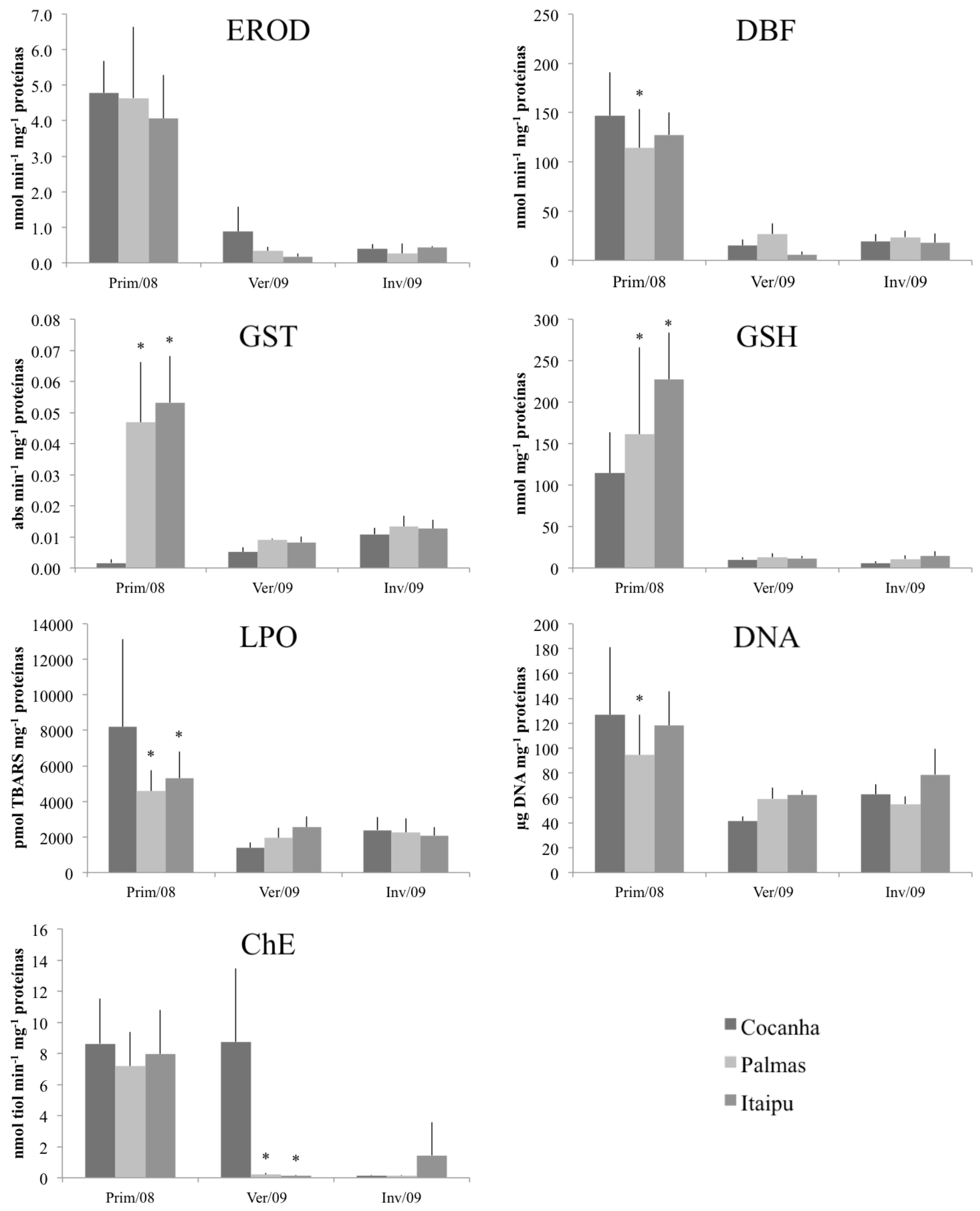

- Cocanha

Palmas

Itaipu

Figura 19. Respostas bioquímicas de EROD, DBF, GST, GSH, DNA, LPO e ChE (média \pm DP) analisadas em brânquias de mexilhões $P$. perna coletados durante a primavera/2008, o verão/2009 e o inverno/2009. Asteriscos indicam diferença significativa em relação à Cocanha $(p<0,05)$. 

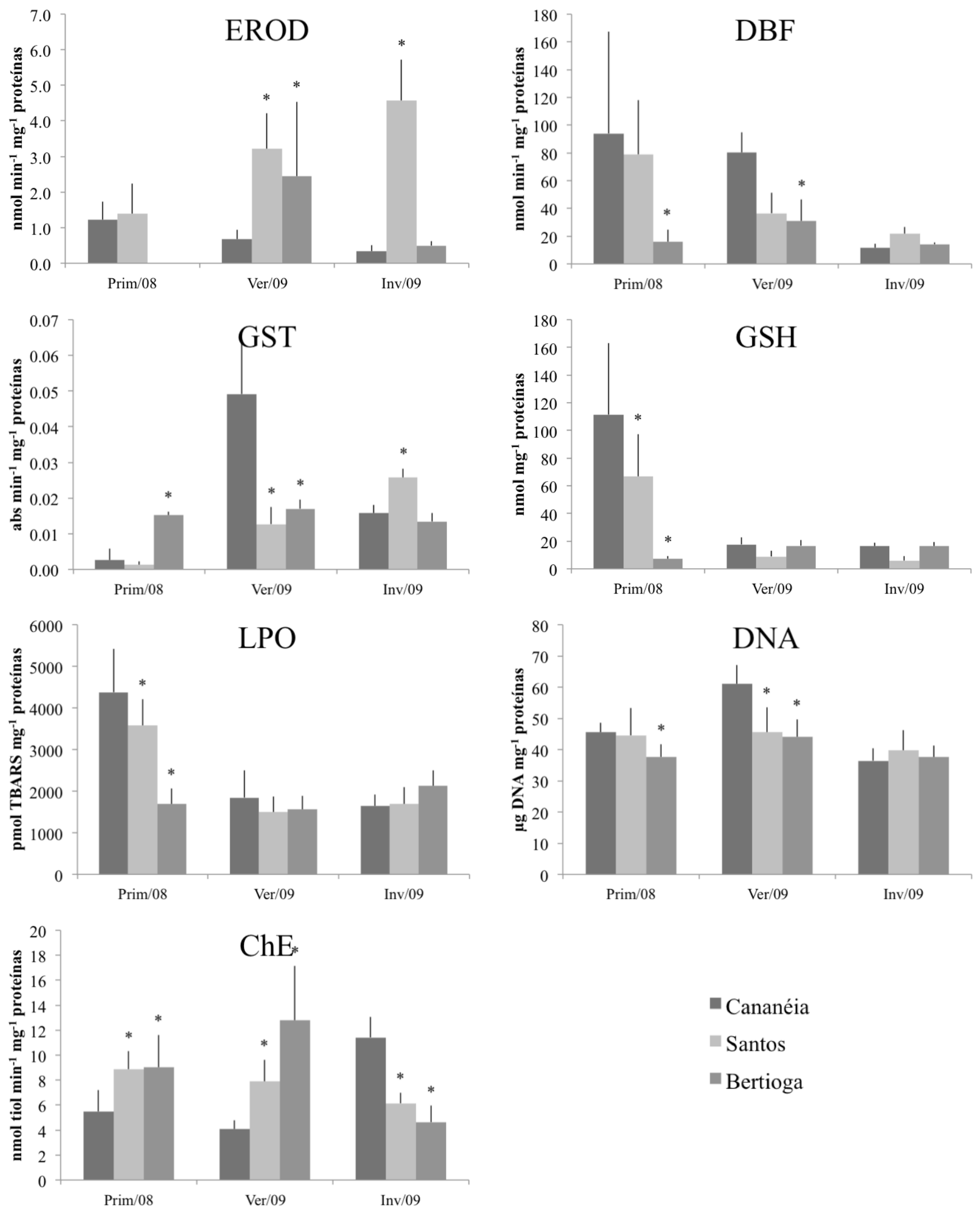

Figura 20. Respostas bioquímicas de EROD, DBF, GST, GSH, DNA, LPO e ChE (média \pm DP) analisadas em brânquias de ostras $C$. brasiliana coletadas durante a primavera/2008, o verão/2009 e o inverno/2009. Asteriscos indicam diferença significativa em relação a Cananéia $(p<0,05)$. 
Durante a primavera de 2008, em relação à fase I da detoxificação nos mexilhões, representada pelas atividades enzimáticas de EROD e DBF, houve alta atividade de DBF na Cocanha e em Itaipu $(\mathrm{p}<0,05)$. A fase II do metabolismo (i.e. atividade enzimática de GST) apresentou maior atividade para os dois pontos de coleta em relação à área de referência $(\mathrm{p}<0,05)$. Quanto ao sistema antioxidante, os teores de GSH foram menores nos organismos coletados na Cocanha $(p<0,05)$. Os efeitos de danos em DNA foram menores para os mexilhões de Palmas, enquanto a peroxidação lipídica ficou evidente na Cocanha $(\mathrm{p}<0,05)$. A atividade enzimática de $\mathrm{ChE}$ não apresentou diferença significativa entre os pontos $(p>0,05)$.

Para os mexilhões coletados durante o verão de 2009, a única resposta bioquímica que apresentou diferença significativa em relação à área de referência foi a atividade de ChE tanto para Palmas quanto para Itaipu $(\mathrm{p}<0,05)$. Para o inverno de 2009, nenhuma resposta bioquímica apresentou diferença significativa relativo à Cocanha $(p>0,05)$.

Quando realizada a comparação entre estações do ano, é possível observar temporalidade nas respostas bioquímicas. Os organismos coletados na Cocanha apresentaram significativo aumento das atividades de EROD e DBF, dos teores de GSH, dos efeitos de DNA e LPO durante a primavera de $2008(\mathrm{p}<0,05)$, e diminuição da atividade de ChE durante o inverno de 2009 (p < 0,05). Em relação à Ilha das Palmas e à Ponta de Itaipu, todas as respostas bioquímicas obtidas para a primavera de 2008 foram significativamente mais altas em relação às outras estações do ano $(p<0,05)$, não havendo diferenças entre verão e inverno.

Os resultados obtidos para as ostras coletadas durante a primavera de 2008 demonstraram alta atividade enzimática de DBF em Cananéia e em Santos $(p<0,05)$. Em relação à fase II do metabolismo, houve baixa atividade de GST para Cananéia e Santos $(p<0,05)$. Também houve altos teores de GSH em Cananéia e Santos $(p<0,05)$. Os danos em DNA e LPO ficaram evidentes em Cananéia e Santos $(\mathrm{p}<0,05)$, enquanto ChE foi menor apenas em Cananéia $(\mathrm{p}<0,05)$.

Durante o verão de 2009, as respostas da fase I de detoxificação se caracterizaram por maior atividade de EROD em Santos e Bertioga $(p<0,05)$ e de DBF em Cananéia $(p<0,05)$. Quanto à fase II do metabolismo, a atividade de GST foi menor em relação a Cananéia nos dois pontos $(\mathrm{p}<0,05)$. Os danos em DNA ficaram evidentes em Cananéia $(p<0,05)$. E os efeitos neurotóxicos apareceram em Cananéia e Santos $(p$ $<0,05)$. Em relação ao inverno de 2009, houve maiores atividades enzimáticas de 
EROD e de GST apenas em Santos $(\mathrm{p}<0,05)$ e menor atividade de ChE em Santos e Bertioga $(\mathrm{p}<0,05)$.

Ao comparar as estações do ano, observa-se que as ostras de Cananéia apresentaram aumento da atividade de DBF durante a primavera de 2008 e o verão de 2009 ( $\mathrm{p}<0,05)$. Com relação à fase II do metabolismo, a atividade de GST aumentou significativamente durante o verão de 2009 ( $\mathrm{p}<0,05)$. O sistema antioxidante respondeu com maiores níveis de GSH na primavera de 2008 ( $\mathrm{p}<0,05)$. Quanto aos efeitos, LPO foi maior na primavera de $2008(\mathrm{p}<0,05)$, DNA foi maior no verão de $2009(\mathrm{p}<0,05)$ e ChE foi maior durante o inverno de $2009(\mathrm{p}<0,05)$.

As ostras coletadas no Estuário de Santos apresentaram aumento da atividade enzimática de EROD e diminuição de DBF durante o verão e o inverno de 2009 (p < 0,05). As alterações na fase II do metabolismo ficaram evidentes no verão e no inverno de 2009, através do aumento da atividade de GST ( $<<0,05)$. GSH e LPO aumentaram na primavera de $2008(\mathrm{p}<0,05)$, enquanto DNA aumentou no verão de $2009(\mathrm{p}<0,05)$.

Já em Bertioga, as únicas respostas bioquímicas que diferiram significativamente em relação às outras estações do ano foram a atividade de EROD durante o verão de 2009 ( $p<0,05)$, LPO durante o inverno de 2009 (p<0,05) e ChE na no inverno de $2009(\mathrm{p}<0,05)$.

\subsubsection{Integração dos resultados}

Através da PCA, as respostas bioquímicas obtidas no presente estudo foram integradas a dados de bioacumulação de metais e de tempos de retenção do corante vermelho neutro mensurados em organismos (mexilhões e ostras) coletados nas mesmas campanhas. Estes dados são parte do trabalho de pós-doutorado da Dra. Marília G. M. C. Semmler e foram utilizados aqui com autorização da pesquisadora.

$\mathrm{O}$ conjunto de dados empregados nas análises de componentes principais (PCA) considerou 8 parâmetros biológicos (EROD, DBF, GST, GSH, LPO, DNA, ChE e NRRT) e 9 parâmetros químicos ( $\mathrm{Cd}, \mathrm{Hg}, \mathrm{Pb}, \mathrm{As}, \mathrm{Cr}, \mathrm{Fe}, \mathrm{Se}, \mathrm{Co}$ e $\mathrm{Zn})$. As matrizes contendo os dados referentes aos mexilhões $P$. perna e às ostras $C$. brasiliana, coletados durante a primavera de 2008, o verão de 2009 e o inverno de 2009, e as tabelas com os resultados das PCAs encontram-se no Apêndice D (Tabela 28, Tabela 29, Tabela 32, Tabela 33, Tabela 34 e Tabela 35).

Os resultados da integração dos dados referentes aos mexilhões coletados nas diferentes estações de 2008/09 mostram que 3 eixos são responsáveis por cerca de 85\% 
da variância total dos dados, dos quais os dois primeiros estão ilustrados na Figura 21. O eixo 1 (36,69\% da variância) associou todos os biomarcadores bioquímicos entre si, correlacionados inversamente a Co. A este fator estiveram associados todos os pontos em todas as estações do ano, exceto Cocanha no verão de 2009 (V09-Coc). O eixo 2 $(33,28 \%)$ correlacionou a maioria dos metais (exceto $\mathrm{Pb}, \mathrm{Co}$ e $\mathrm{Zn}$ ) entre si, associados inversamente a GST. Este fator se associou a todas as estações da Cocanha (P08-Coc, V09-Coc, I09-Coc), Palmas na primavera de 2008 (P08-Pal), e Itaipu na primavera de 2008 e no verão de 2009 (P08-Ita, V09-Ita). O terceiro eixo $(15,16 \%)$ associou NRRT a $\mathrm{Pb}$ e inversamente a $\mathrm{Se}$ e $\mathrm{Zn}$. Todos os pontos do verão e do inverno de 2009 se associaram a este fator, exceto Palmas no inverno de 2009 (V09-Coc, V09-Pal, V09-Ita, I09-Coc, I09-Ita).

A integração dos dados referentes às ostras coletadas nas diferentes estações de 2008/09 mostram que 3 eixos são responsáveis por cerca de 77\% da variância total dos dados (Apêndice D), sendo que os dois primeiros estão ilustrados na Figura 22. O eixo 1 (40,63\% da variância) correlacionou EROD a todos os metais, exceto As. Por outro lado, NRRT e GSH também estiveram associados neste eixo. Este fator é representativo para Cananéia na primavera de 2008 (P08-Can), Santos em todas as estações (P08-San, V09-San, I09-San), e Bertioga no verão de 2009 (V09-Ber). O eixo 2 (20,66\%) associou os biomarcadores bioquímicos (exceto EROD e GST) a $\mathrm{Cd}$, sendo que a relação estabelecida com ChE foi inversa. Todos os pontos são representados por este fator, exceto Santos no inverno de 2009 (I09-San). O eixo 3 (15,75\%) correlacionou GST, As e Se, sendo representativo apenas para Cananéia no verão de 2009 (V09-Can). 


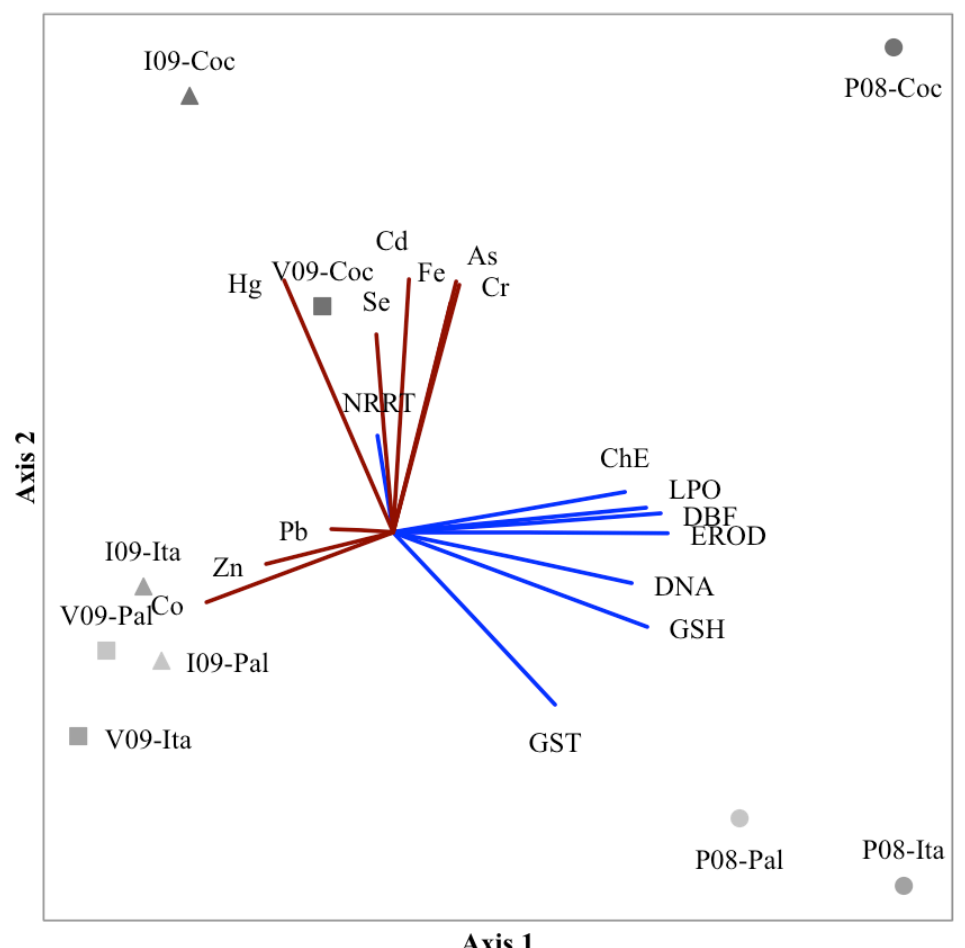

Figura 21. Ordenação dos resultados (loadings e scores) da análise de componentes principais baseada nos dados de bioacumulação de metais (vermelho), biomarcadores bioquímicos e físiológico (azul) obtidos para mexilhões $P$. perna coletados durante a primavera/2008, o verão/2009 e o inverno/2009.

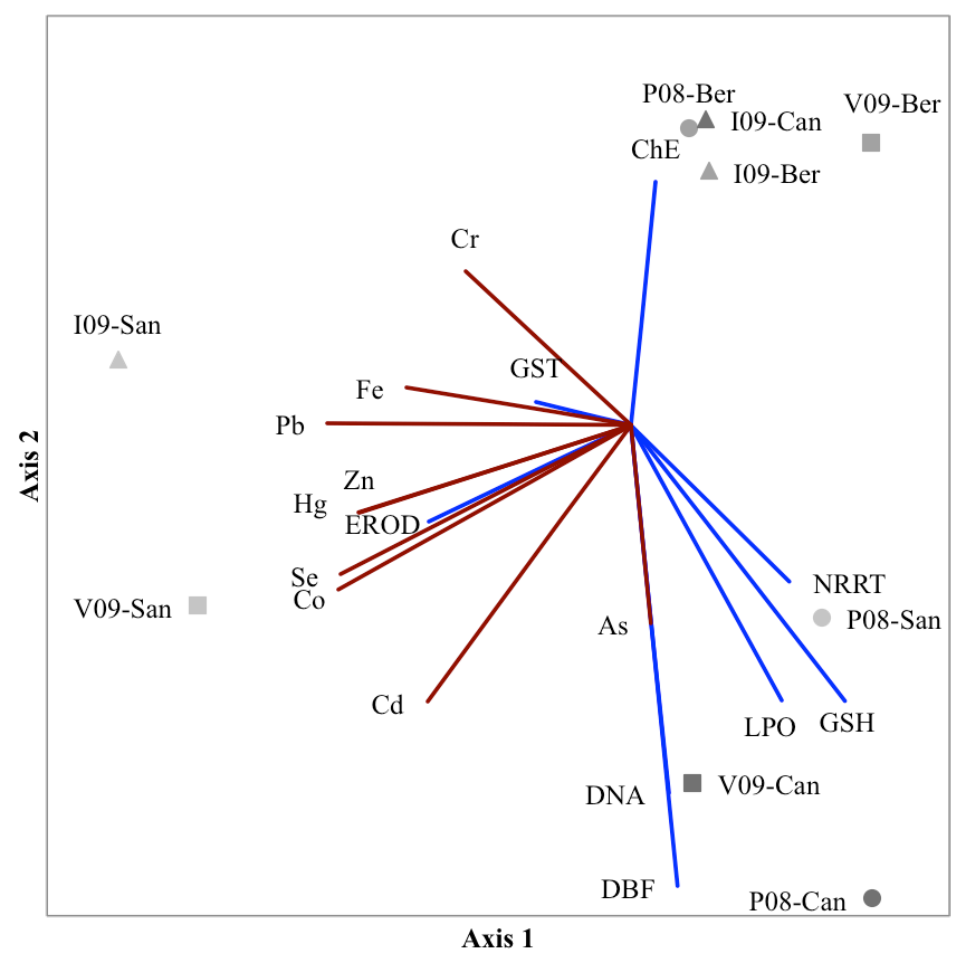

Figura 22. Ordenação dos resultados (loadings e scores) da análise de componentes principais baseada nos dados de bioacumulação de metais (vermelho), biomarcadores bioquímicos e fisiológico (azul) obtidos para ostras C. brasiliana coletadas durante a primavera/2008, o verão/2009 e o inverno/2009. 


\subsection{Campanha de 2016/17}

\subsubsection{Bioacumulação de metais}

Os resultados das análises de bioacumulação de metais em tecidos de mexilhões coletados durante a primavera de 2016 e o outono de 2017 estão apresentados na Tabela 9 e Figura 23. Os resultados das análises de bioacumulação de metais em tecidos de ostras coletadas durante a primavera de 2016 e o outono de 2017 estão apresentados na Tabela 10 e Figura 24. 


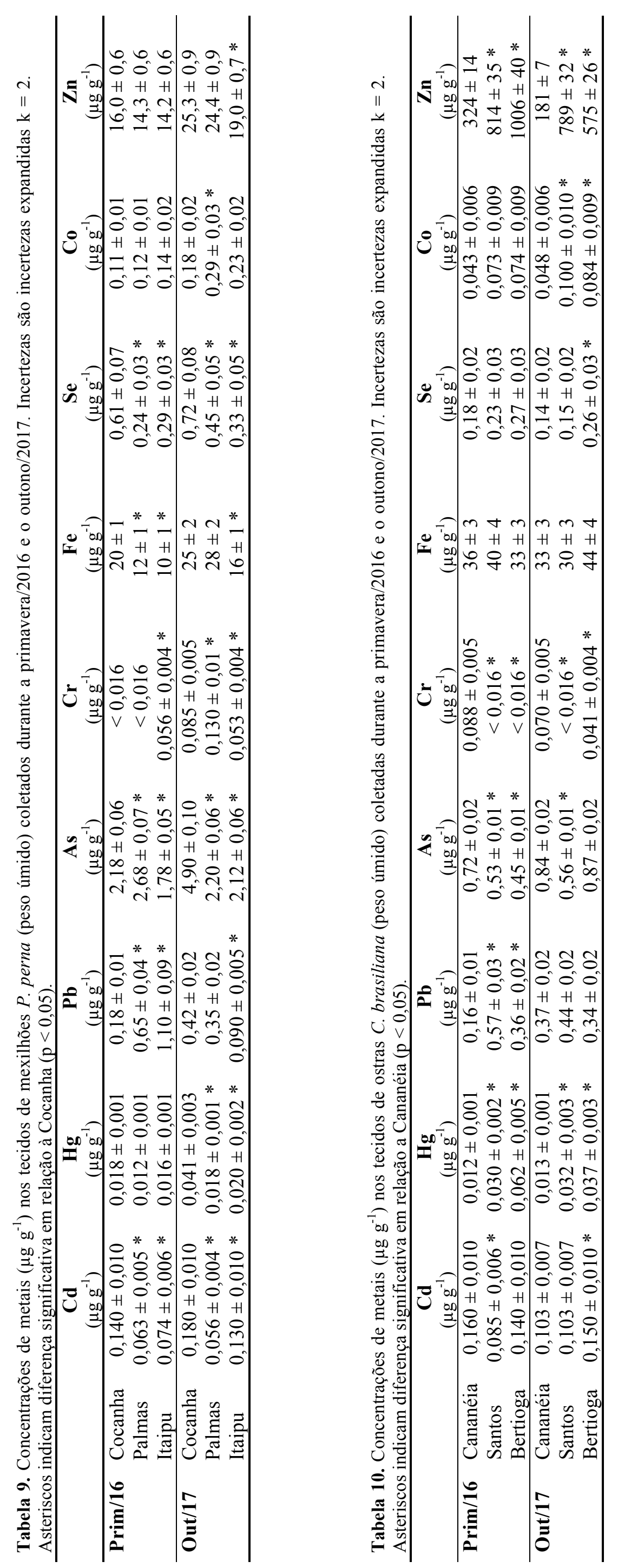



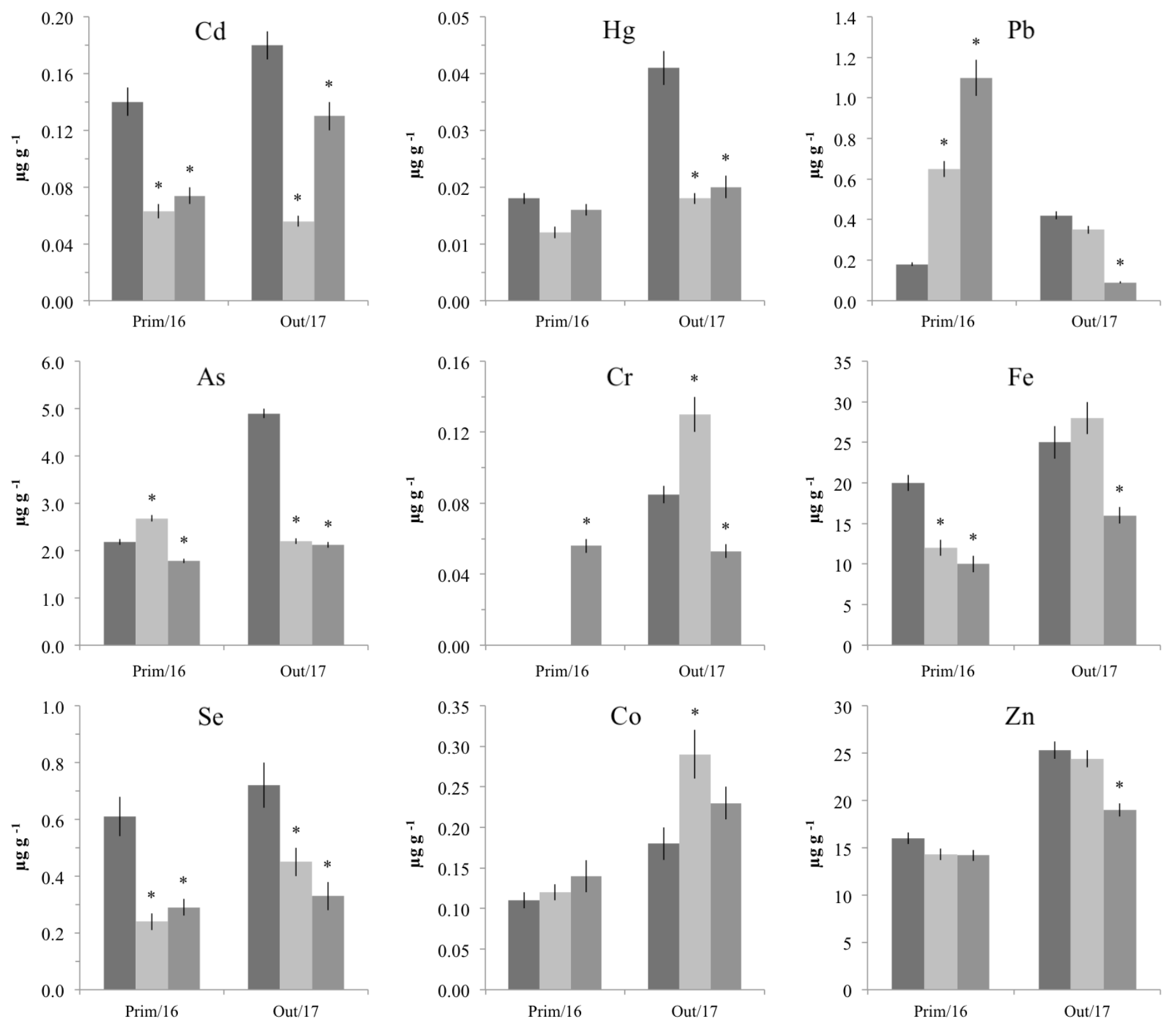

\section{- Cocanha Palmas $\quad$ Itaipu}

Figura 23. Concentrações de metais $\left(\mu \mathrm{g} \mathrm{g}^{-1}\right)$ nos tecidos de mexilhões $P$. perna (peso úmido) coletados durante a primavera/2016 e o outono/2017. Incertezas são incertezas expandidas $\mathrm{k}=2$. Asteriscos indicam diferença significativa em relação à Cocanha $(\mathrm{p}<0,05)$. 

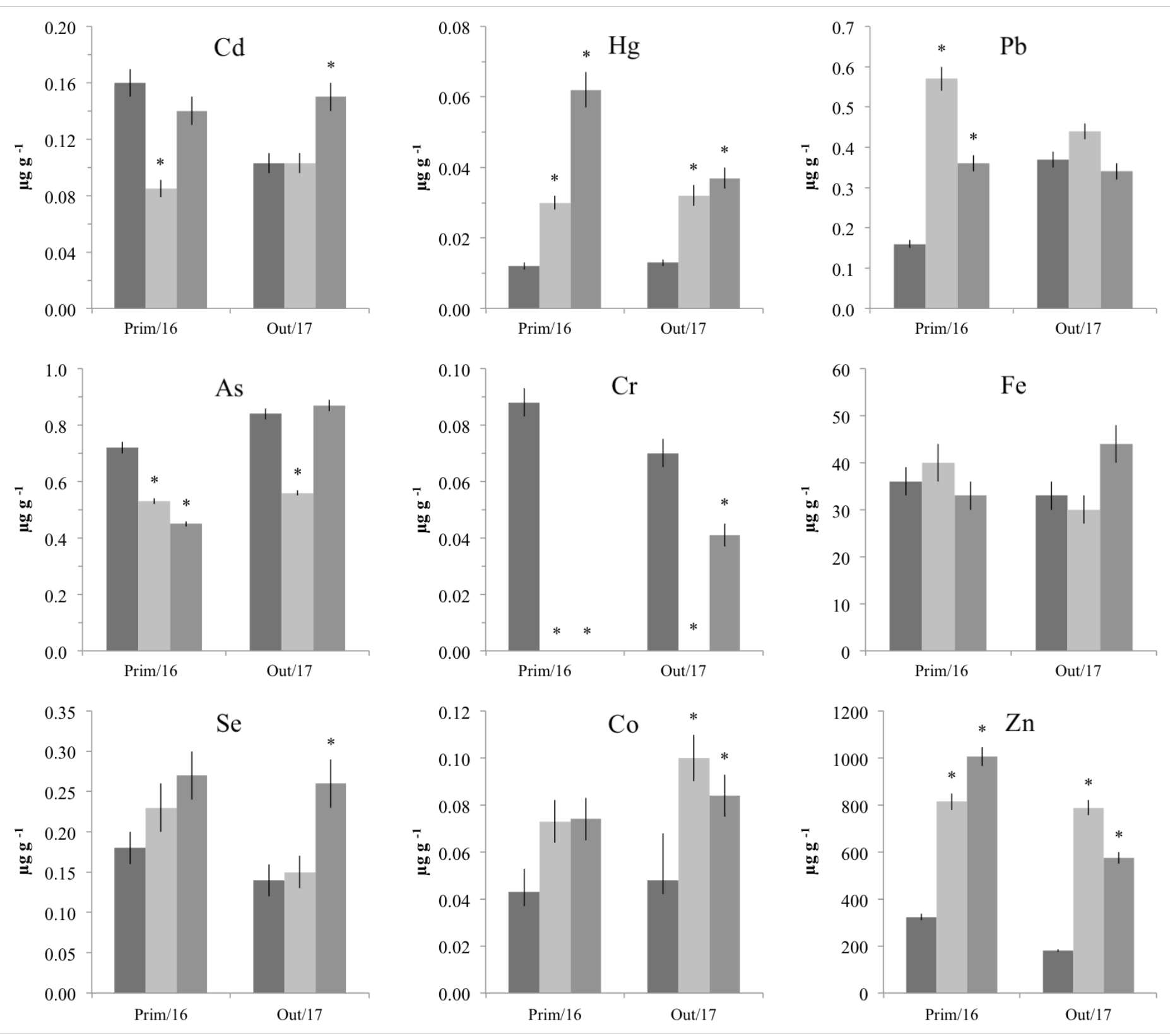

- Cananéia $\square$ Santos $\square$ Bertioga

Figura 24. Concentrações de metais $\left(\mu \mathrm{g} \mathrm{g}^{-1}\right)$ nos tecidos de ostras C. brasiliana (peso úmido) coletadas durante a primavera/2016 e o outono/2017. Incertezas são incertezas expandidas $\mathrm{k}=2$. Asteriscos indicam diferença significativa em relação a Cananéia $(\mathrm{p}<0,05)$.

Os resultados das análises de metais nos mexilhões coletados na primavera de 2016 demonstraram que os elementos $\mathrm{Cd}$, Fe e Se apresentaram maiores concentrações na Cocanha, diferindo significativamente dos outros dois pontos $(\mathrm{p}<0,05)$. O elemento $\mathrm{Pb}$ apresentou maiores concentrações em Palmas e Itaipu em relação aos teores medidos para a Cocanha $(p<0,05)$. As concentrações de As foi maior em Palmas e menor em Itaipu, relativo à Cocanha $(\mathrm{p}<0,05)$. $\mathrm{O}$ elemento $\mathrm{Cr}$ foi detectado apenas nos organismos coletados em Itaipu. Os elementos $\mathrm{Hg}$, Co e $\mathrm{Zn}$ não apresentaram diferença 
significativa entre os pontos $(\mathrm{p}>0,05)$, porém é possível observar que $\mathrm{Hg}$ e $\mathrm{Zn}$ foram maiores na Cocanha. No outono de 2017, os elementos Cd, Hg, As e Se apresentaram maiores concentrações para a Cocanha, sendo significativamente diferente de Palmas e Itaipu $(\mathrm{p}<0,05)$. Além disso, $\mathrm{Pb}, \mathrm{Cr}, \mathrm{Fe}$ e $\mathrm{Zn}$ também tiveram altas concentrações na Cocanha, diferindo apenas de Itaipu $(\mathrm{p}<0,05)$. Os teores de $\mathrm{Cr}$ e Co foram maiores em Palmas em relação à Cocanha $(\mathrm{p}<0,05)$.

Analisando os pontos individualmente, as maiores concentrações de $\mathrm{Cd}, \mathrm{Hg}, \mathrm{Se}$ e $\mathrm{Zn}$ ocorreram nos organismos coletados na Cocanha em ambas as estações do ano. Neste mesmo local, ocorreram os maiores teores de Fe apenas na primavera de 2016 e de $\mathrm{Pb}$ e As apenas no outono de 2017. Os organismos coletados em Palmas apresentaram as maiores concentrações de As na primavera de 2016 e de $\mathrm{Cr}$, Fe e Co durante o outono de 2017. Já em Itaipu ocorreram os maiores valores de $\mathrm{Pb}, \mathrm{Cr}$ e $\mathrm{Co}$ na primavera de 2016.

Quando comparadas as estações do ano para cada ponto de coleta, é possível observar que a maioria das altas concentrações ocorreu durante o outono de 2017 . Na Cocanha, os teores de $\mathrm{Cd}, \mathrm{Hg}, \mathrm{As}, \mathrm{Cr}$ e $\mathrm{Zn}$ foram significativamente diferentes entre as estações, apresentando maiores valores durante o outono de 2017 ( $p<0,05)$. Para Palmas, os elementos $\mathrm{Pb}$ e As apresentaram maiores concentrações durante a primavera de 2016, enquanto $\mathrm{Cr}$, Fe, Co e $\mathrm{Zn}$ foram maiores durante o outono de 2017 ( $p<0,05)$. Em Itaipu, a quantidade de elementos que apresentaram diferença entre as estações foi menor: apenas $\mathrm{Pb}$ foi maior durante a primavera de 2016, e $\mathrm{Cd}$, As e $\mathrm{Zn}$ foram maiores durante o outono de $2017(\mathrm{p}<0,05)$.

Já os resultados obtidos para as ostras coletadas na primavera de 2016 demonstraram que Cananéia apresentou maiores concentrações de As e $\mathrm{Cr}$ em relação a Santos e Bertioga $(\mathrm{p}<0,05)$, e altas concentrações de Cd, diferindo apenas de Santos. Por outro lado, Santos e Bertioga apresentaram maiores teores de $\mathrm{Hg}, \mathrm{Pb}$ e $\mathrm{Zn}$ em relação a Cananéia $(\mathrm{p}<0,05)$. Os elementos $\mathrm{Fe}$, Se e Co não apresentaram diferença significativa entre os pontos $(\mathrm{p}>0,05)$. No outono de 2017, As e $\mathrm{Cr}$ mantiveram altas concentrações na área de referência, diferindo de Santos $(\mathrm{p}<0,05)$ e de Santos e Bertioga $(\mathrm{p}<0,05)$, respectivamente. As concentrações de $\mathrm{Hg}$, Co e $\mathrm{Zn}$ foram maiores em Santos e Bertioga, diferindo significativamente de Cananéia $(p<0,05)$. Além disso, $\mathrm{Cd}$ e Se apresentaram maiores concentrações em Bertioga $(\mathrm{p}<0,05)$. Os elementos $\mathrm{Pb}$ e Fe não apresentaram diferença significativa entre os pontos $(p>0,05)$. 
Examinando os pontos de coleta individualmente, os organismos coletados em Cananéia apresentaram as maiores concentrações $\mathrm{Cd}$, As e $\mathrm{Cr}$ durante a primavera de 2016 e as maiores concentrações de $\mathrm{Cr}$ durante o outono de 2017. Os organismos coletados em Santos apresentaram as maiores concentrações de $\mathrm{Pb}$ e Fe na primavera de 2016, enquanto as maiores concentrações de $\mathrm{Pb}$, Co e $\mathrm{Zn}$ ocorreram no outono de 2017. Já os organismos coletados em Bertioga foram aqueles que apresentaram a maioria das maiores concentrações: os maiores valores de $\mathrm{Hg}$, Se, Co e $\mathrm{Zn}$ ocorreram na primavera de 2016, enquanto no outono de 2017 houve os maiores teores de $\mathrm{Cd}, \mathrm{Hg}, \mathrm{As}, \mathrm{Fe}$ e $\mathrm{Se}$.

Quando comparadas as estações do ano, identificamos que em Cananéia, os elementos Cd, Cr e Zn tiveram concentrações mais altas durante a primavera de 2016, enquanto $\mathrm{Pb}$ e As foram maiores no outono de 2017. Em Santos, apenas as concentrações de $\mathrm{Pb}$ foram diferentes entre as estações, sendo maiores durante a primavera de 2016. Já para Bertioga, $\mathrm{Hg}$ e Zn apresentaram maiores concentrações durante a primavera de 2016, e As e Cr foram maiores no outono de 2017.

\subsubsection{Biomarcadores bioquímicos}

As respostas bioquímicas dos biomarcadores analisados nos tecidos branquiais de mexilhões coletados durante a primavera de 2016 e o outono de 2017 nos diferentes pontos de coleta estão apresentadas na Tabela 11 e na Figura 25. As respostas bioquímicas dos biomarcadores analisados nos tecidos branquiais de ostras coletadas durante a primavera de 2016 e o outono de 2017 nos diferentes pontos de coleta estão apresentadas na Tabela 12 e na Figura 26. 

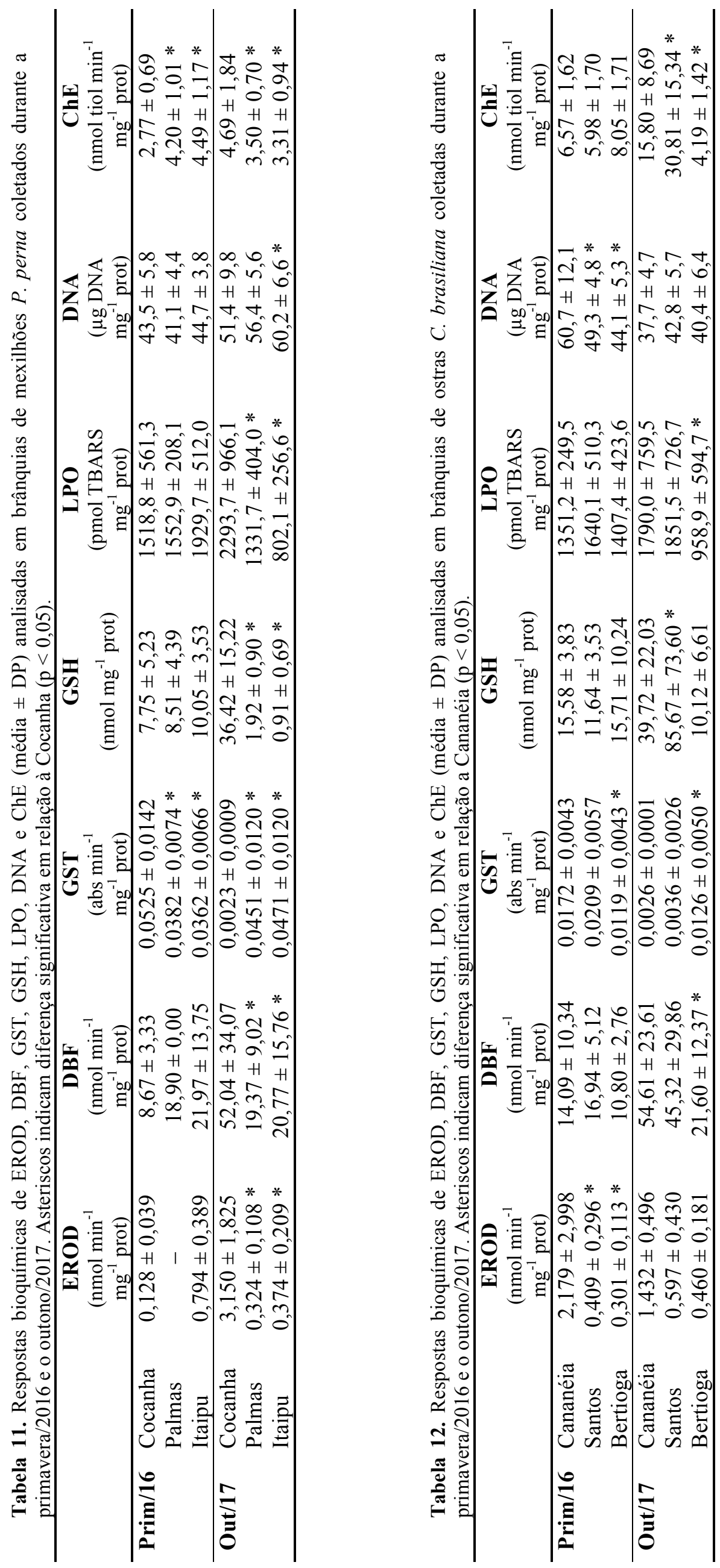

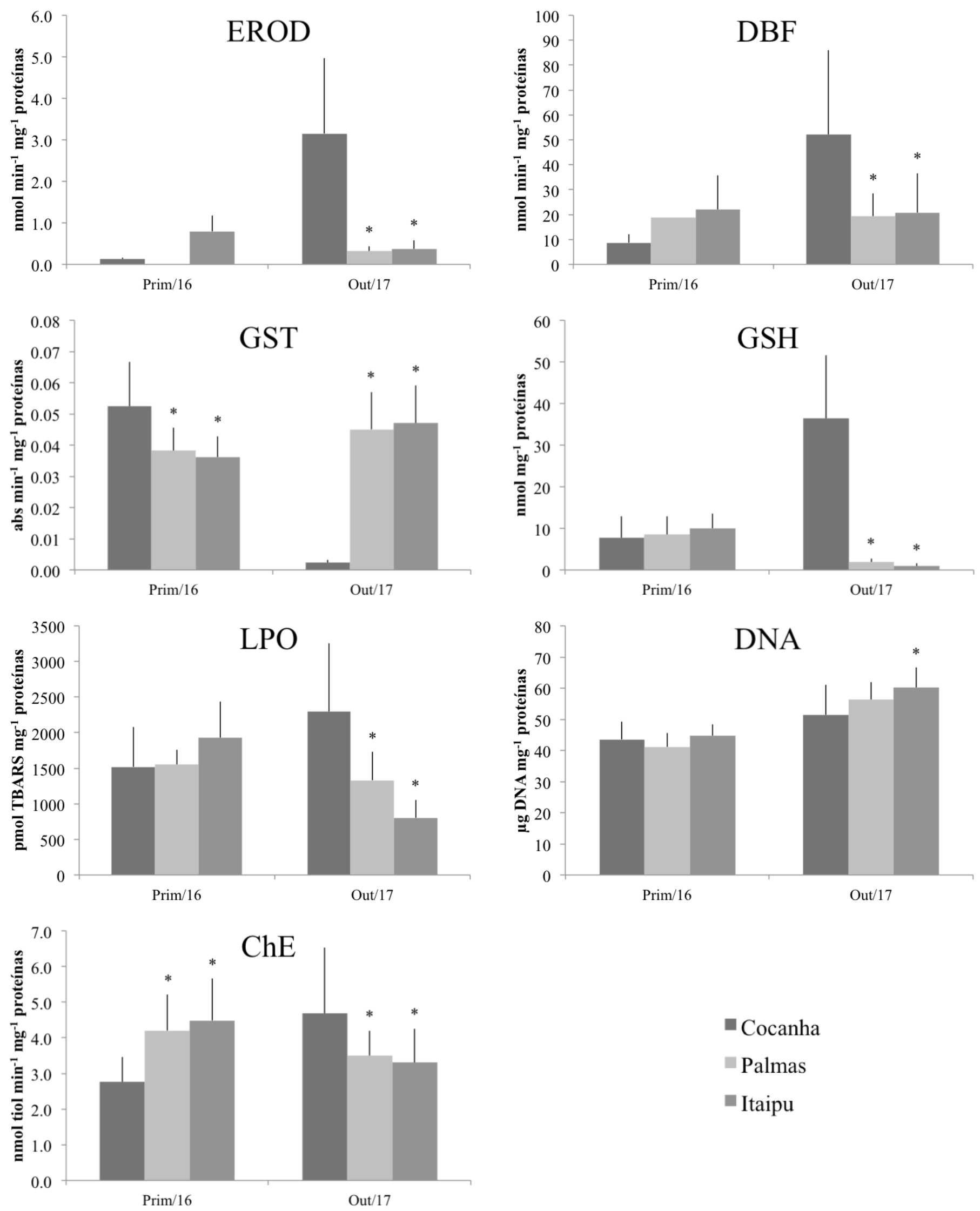

- Cocanha

- Palmas

Itaipu

Figura 25. Respostas bioquímicas de EROD, DBF, GST, GSH, LPO, DNA e ChE (média \pm DP) analisadas em brânquias de mexilhões $P$. perna coletados durante a primavera/2016 e o outono/2017. Asteriscos indicam diferença significativa em relação à Cocanha $(\mathrm{p}<0,05)$. 

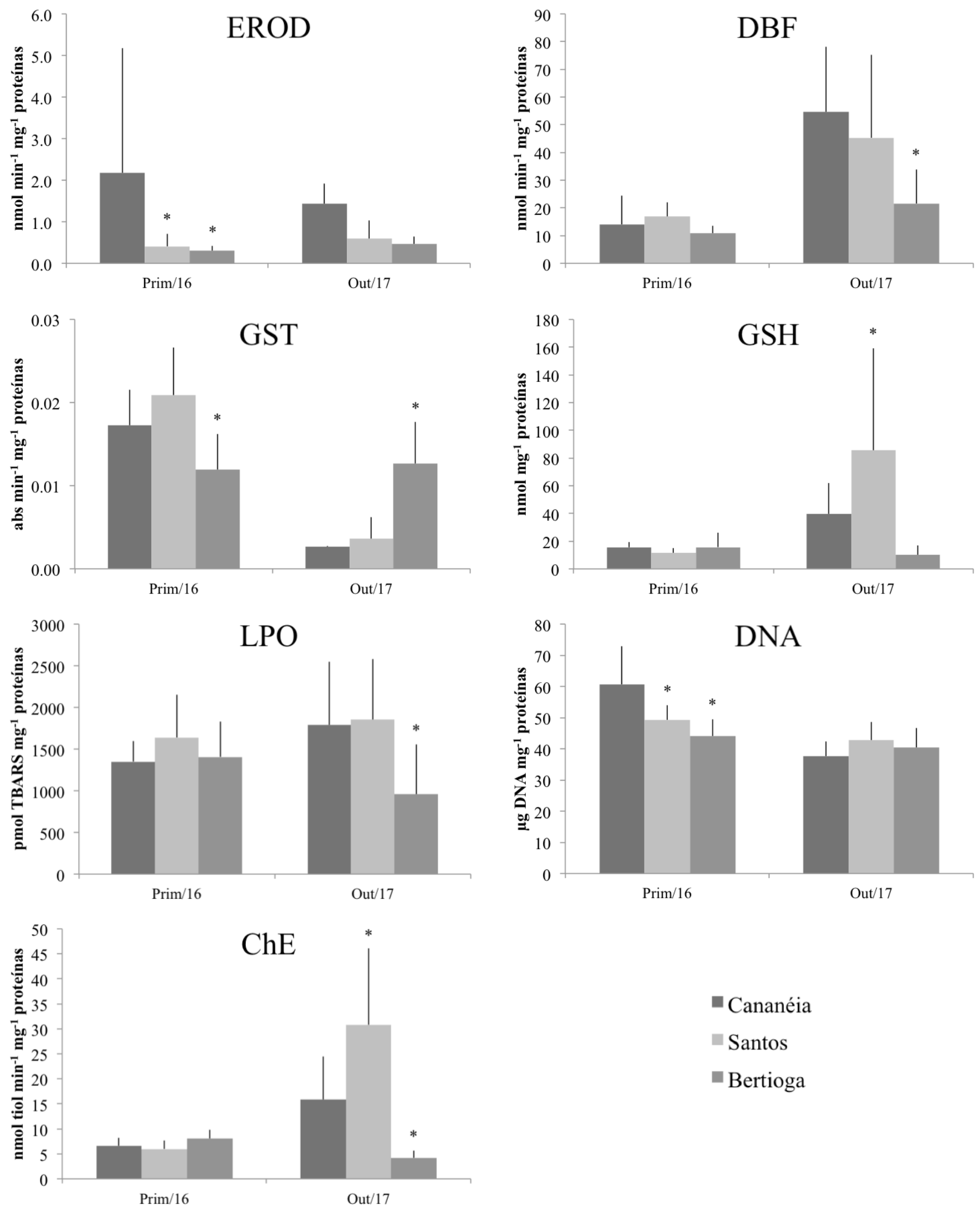

Figura 26. Respostas bioquímicas de EROD, DBF, GST, GSH, LPO, DNA e ChE (média \pm DP) analisadas em brânquias de ostras C. brasiliana coletadas durante a primavera/2016 e o outono/2017. Asteriscos indicam diferença significativa em relação a Cananéia $(\mathrm{p}<0,05)$. 
As respostas bioquímicas medidas nos mexilhões coletados durante a primavera de 2016 demonstraram que a fase I do metabolismo (i.e. atividade enzimática de EROD e DBF), o sistema antioxidante (i.e. teores de GSH) e os níveis de LPO e DNA não apresentaram diferença significativa entre os pontos de coleta $(p>0,05)$. A atividade enzimática de GST, que representa resposta da fase II do metabolismo, foi menor para Palmas e Itaipu em relação à Cocanha $(\mathrm{p}<0,05)$. Além disso, a atividade enzimática de $\mathrm{ChE}$ em ambos os pontos foi maior em relação à Cocanha $(p<0,05)$. Já no outono de 2017, as atividades enzimáticas de EROD e DBF foram menores em relação à Cocanha tanto para Palmas quanto para Itaipu $(p<0,05)$. A atividade de GST aumentou e os teores de GSH foram menores em Palmas e em Itaipu $(\mathrm{p}<0,05)$. Quanto aos biomarcadores de efeito, ficaram evidentes a peroxidação lipídica na Cocanha e danos em DNA em Itaipu $(p<0,05)$, além de efeito neurotóxico, através da reduzida atividade de $\mathrm{ChE}$ em Palmas e Itaipu $(\mathrm{p}<0,05)$.

Quando realizada a comparação entre as estações do ano, é possível observar temporalidade nas respostas bioquímicas, principalmente em relação à área de referência. Os organismos coletados na Cocanha apresentaram significativo aumento das atividades de EROD e DBF, dos teores de GSH, LPO e DNA e da atividade de ChE, e diminuição da atividade de GST no outono de 2017, em comparação aos resultados obtidos na primavera de 2016. Em relação à Ilha das Palmas e à Ponta de Itaipu, os teores de DNA foram maiores no outono de 2017 para ambos os pontos (p < $0,05)$ e LPO foi maior em Itaipu na primavera de $2016(p<0,05)$.

As ostras coletadas durante a primavera de 2016 demonstraram maior atividade de EROD em Cananéia $(p<0,05)$. A atividade de GST foi menor em relação a Cananéia apenas em Bertioga $(p<0,05)$. Houve também efeitos no DNA em Cananéia $(\mathrm{p}<0,05)$. Já no outono de 2017, a fase I do metabolismo apresentou menor atividade de DBF apenas para Bertioga $(\mathrm{p}<0,05)$, enquanto na fase II houve maior atividade de GST no mesmo ponto $(\mathrm{p}<0,05)$. Os teores de GSH foram maiores em Santos $(\mathrm{p}<$ 0,05). Os efeitos de LPO foram menores em Bertioga $(\mathrm{p}<0,05)$. Quanto aos efeitos neurotóxicos, a atividade de ChE foi maior em Santos e menor em Bertioga $(p<0,05)$, relativo à resposta obtida de Cananéia.

Ao comparar as estações do ano, observa-se que as ostras de Cananéia apresentaram aumento da atividade de $\operatorname{DBF}(\mathrm{p}<0,05)$, diminuição da atividade de GST $(\mathrm{p}<0,05)$ e de danos no DNA $(\mathrm{p}<0,05)$ e aumento da atividade de ChE $(\mathrm{p}<0,05)$ durante o outono de 2017. As ostras coletadas no estuário de Santos apresentaram 
aumento da atividade enzimática de DBF $(\mathrm{p}<0,05)$, diminuição da atividade de GST ( $\mathrm{p}$ $<0,05)$, aumento dos teores de GSH $(\mathrm{p}<0,05)$ e da atividade de $\mathrm{ChE}(\mathrm{p}<0,05)$ durante o outono de 2017. Já em Bertioga, nenhuma resposta bioquímica apresentou diferença entre as estações do ano.

\subsubsection{Biomarcador fisiológico}

Os tempos de retenção do vermelho neutro (NRRT) observados para os mexilhões coletados durante a primavera de 2016 e o outono de 2017 estão apresentados na Tabela 13 e na Figura 27. Durante a primavera, não houve redução significativa do tempo de retenção do corante em relação aos organismos da área de referência $(\mathrm{p}>0,05)$. Contrariamente, na campanha realizada no outono houve redução significativa do tempo de retenção do corante pelos organismos de Palmas e de Itaipu quando comparados aos organismos da Cocanha $(\mathrm{p}<0,05)$. Ainda, foi possível observar aumento significativo dos tempos de retenção no outono em relação à primavera para os organismos coletados na Cocanha e na Ilha das Palmas $(\mathrm{p}<0,05)$.

Tabela 13. Tempos de retenção do corante vermelho neutro (média \pm DP) observados para mexilhões $P$. perna e ostras $C$. brasiliana coletados durante a primavera/2016 e o outono/2017. Asteriscos indicam diferença significativa em relação à Cocanha e a Cananéia, respectivamente $(\mathrm{p}<0,05)$.

\begin{tabular}{llcc}
\hline & \multicolumn{1}{c}{$\begin{array}{c}\text { Prim/16 } \\
\text { (minutos) }\end{array}$} & $\begin{array}{c}\text { Out/17 } \\
\text { (minutos) }\end{array}$ \\
\hline Mexilhões & Cocanha & $41,47 \pm 9,96$ & $81,18 \pm 27,59$ \\
P. perna & Palmas & $44,06 \pm 16,85$ & $58,24 \pm 4,98^{*}$ \\
& Itaipu & $45,00 \pm 8,32$ & $48,53 \pm 8,43 *$ \\
\hline Ostras & Cananéia & $37,94 \pm 9,36$ & $57,35 \pm 5,89$ \\
C. brasiliana & Santos & $33,75 \pm 13,96$ & $23,82 \pm 7,61 *$ \\
& Bertioga & $37,94 \pm 18,46$ & $43,23 \pm 10,45^{*}$ \\
\hline
\end{tabular}




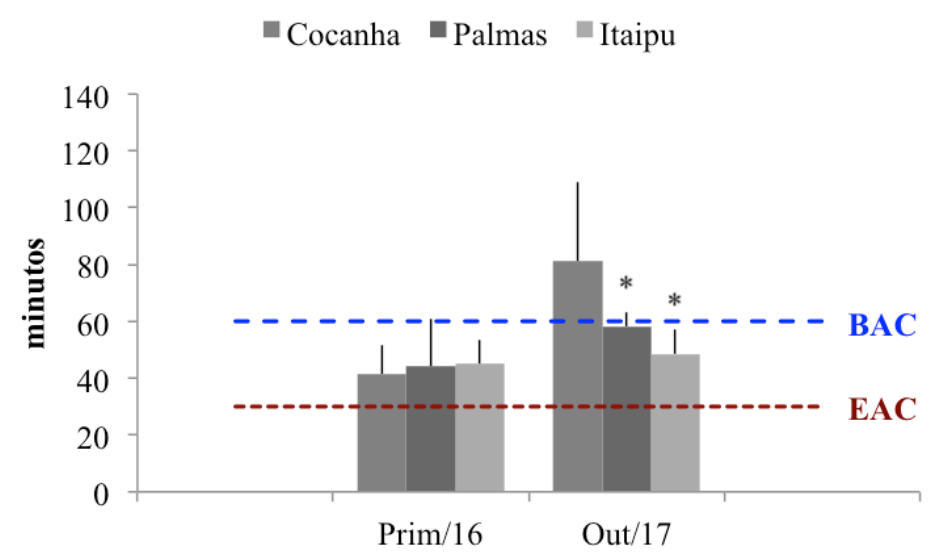

Figura 27. Tempos de retenção do corante vermelho neutro (média \pm DP) observados para mexilhões $P$. perna coletados na primavera/2016 e no outono/2017. Asteriscos representam diferença significativa em relação à Cocanha $(\mathrm{p}<0,05)$. A linha vermelha pontilhada representa environmental assessment criteria (= $30 \mathrm{~min})$ e a linha pontilhada azul representa background assessment criteria $(=60 \mathrm{~min})$, de acordo com Ortega et al. (2018).

Os tempos de retenção do vermelho neutro observados para as ostras coletadas durante a primavera de 2016 e o outono de 2017 estão apresentados na Tabela 13 e na Figura 28. Assim como observado nos mexilhões, durante a primavera não houve redução significativa do tempo de retenção do vermelho neutro em relação à área de referência $(p>0,05)$; enquanto que no outono, uma redução significativa deste tempo foi observada $(\mathrm{p}<0,05)$. Na campanha do outono, é possível observar que as ostras coletadas no estuário de Santos obtiveram o menor tempo de retenção, havendo redução em relação à primavera $(\mathrm{p}<0,05)$. Além disso, houve aumento do tempo de retenção em Cananéia no outono em relação à primavera $(\mathrm{p}<0,05)$.

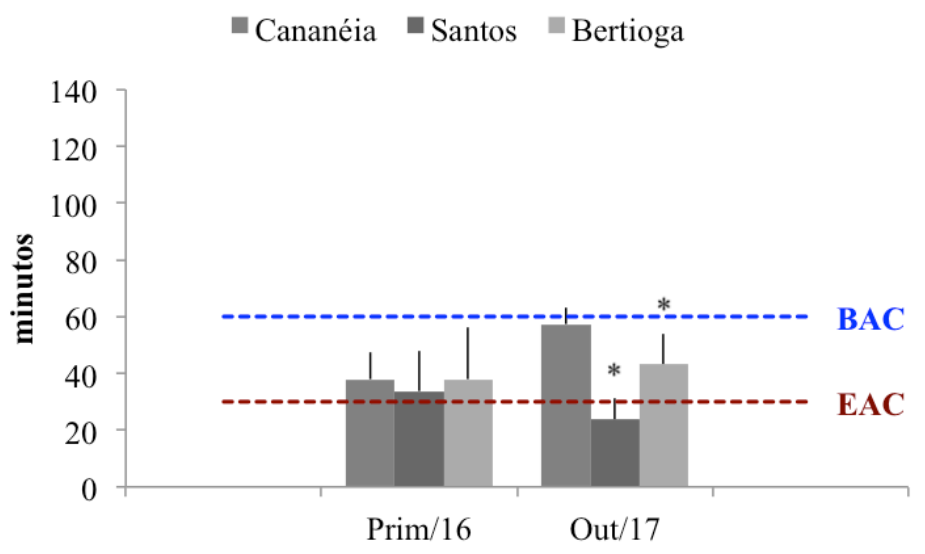

Figura 28. Tempos de retenção do corante vermelho neutro (média $\pm \mathrm{DP}$ ) observados para ostras $C$. brasiliana coletadas na primavera/2016 e no outono/2017. Asteriscos representam diferença significativa em relação a Cananéia $(\mathrm{p}<0,05)$. A linha vermelha pontilhada representa environmental assessment criteria (= $30 \mathrm{~min})$ e a linha pontilhada azul representa background assessment criteria (= $60 \mathrm{~min})$, de acordo com Ortega et al. (2018). 


\subsubsection{Integração dos dados}

O conjunto de dados empregados nas análises de componentes principais (PCA) considerou 8 parâmetros biológicos (EROD, DBF, GST, GSH, LPO, DNA, ChE e NRRT) e 9 parâmetros químicos ( $\mathrm{Cd}, \mathrm{Hg}, \mathrm{Pb}, \mathrm{As}, \mathrm{Cr}, \mathrm{Fe}, \mathrm{Se}, \mathrm{Co}$ e $\mathrm{Zn})$. As matrizes contendo os dados referentes aos mexilhões $P$. perna e às ostras $C$. brasiliana, coletados durante a primavera de 2016 e o outono de 2017, e as tabelas com os resultados das PCAs encontram-se no Apêndice D (Tabela 30, Tabela 31, Tabela 36, Tabela 37, Tabela 38 e Tabela 39).

Os resultados da integração das respostas bioquímicas aos dados de bioacumulação de metais mensurados nos mexilhões coletados durante a primavera de 2016 e o outono de 2017 por meio da PCA demonstram que 3 eixos são responsáveis por cerca de $92 \%$ da variância dos dados, sendo que os dois primeiros estão representados na Figura 29. O eixo 1 (48,79\% da variância) associou a maioria das variáveis biológicas (exceto $\mathrm{DNA}$ e $\mathrm{ChE}$ ) às concentrações de $\mathrm{Cd}, \mathrm{Hg}, \mathrm{As}, \mathrm{Cr}, \mathrm{Fe}, \mathrm{Se} e$ Zn. Vale ressaltar que GST se associou às outras variáveis de maneira inversa. Este fator é representativo para a Cocanha na primavera de 2016 (P16-Coc) e no outono de 2017 (O17-Coc), e para Palmas na primavera de 2016 (P16-Pal). O segundo eixo (27,92\%) correlacionou GSH e LPO a Pb e DNA a Cr, Fe, Co e Zn. Este fator é representativo para Palmas e Itaipu em ambas as estações do ano (P16-Pal, P16-Ita, O17-Pal, O17-Ita). O terceiro eixo (15,65\%) associou $\mathrm{ChE}$ a $\mathrm{Pb}$ e $\mathrm{Cr}$ e inversamente a Cd e Se, sendo representativo para P16-Coc, P16-Ita e O17-Pal.

Em relação à integração dos dados mensurados nas ostras coletadas durante a primavera de 2016 e o outono de 2017, os resultados demonstram que 3 eixos são responsáveis por cerca de $85 \%$ da variância total dos dados (Apêndice D), dos quais os dois primeiros estão representados na Figura 30. O primeiro eixo (38,88\% da variância) associou EROD, DBF, GSH, LPO e ChE entre si, enquanto GST foi correlacionada a $\mathrm{Hg}, \mathrm{Fe}$, Se e $\mathrm{Zn}$. A este fator associaram-se todos os pontos, exceto Cananéia na primavera de 2016 (P16-Can). O segundo eixo (31,57\%) correlacionou NRRT a Cd, As e $\mathrm{Cr}$, enquanto $\mathrm{Hg}, \mathrm{Pb}, \mathrm{Co}$ e $\mathrm{Zn}$ se correlacionaram entre si. Este fator é representativo para todos os pontos em todas as estações. O terceiro eixo $(14,96 \%)$ pode ser considerado residual, uma vez que os biomarcadores de efeito LPO e DNA estiveram correlacionados entre si, mas a nenhuma outra variável. 


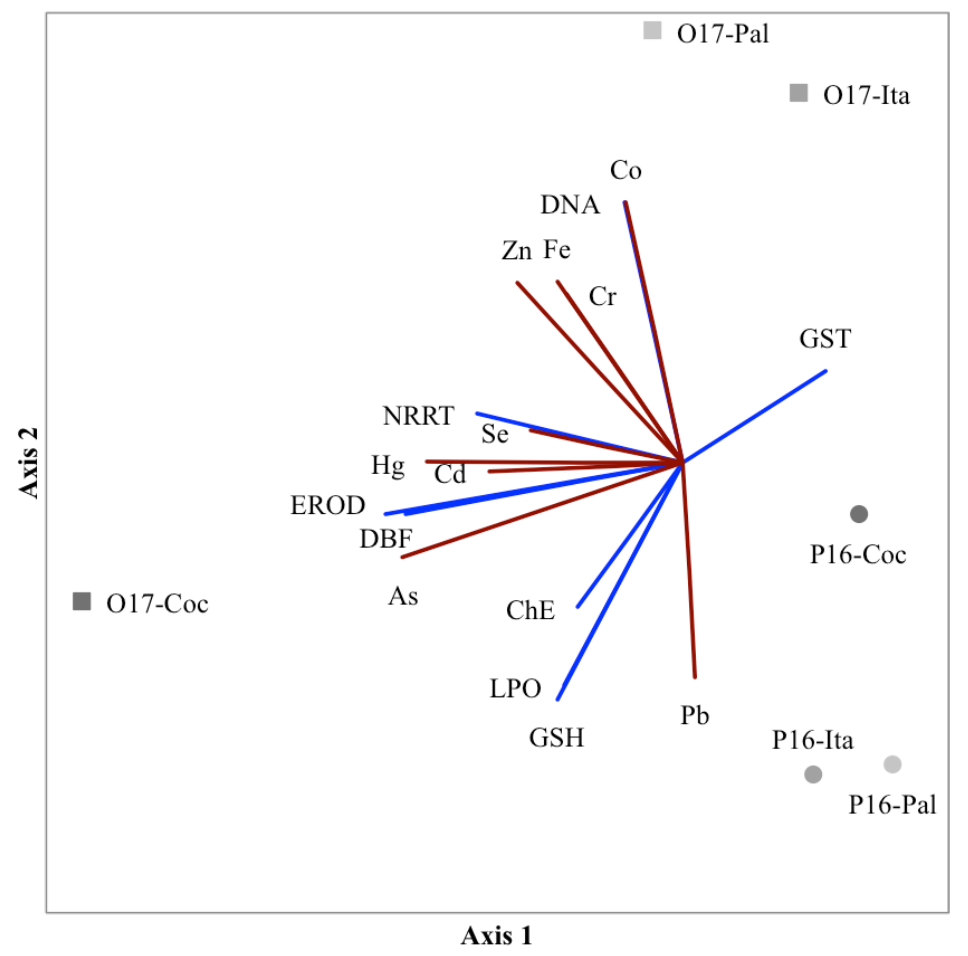

Figura 29. Ordenação dos resultados (loadings e scores) da análise de componentes principais baseada nos dados de bioacumulação de metais (vermelho), biomarcadores bioquímicos e fisiológico (azul) obtidos para mexilhões $P$. perna coletados durante a primavera/2016 e o outono/2017.

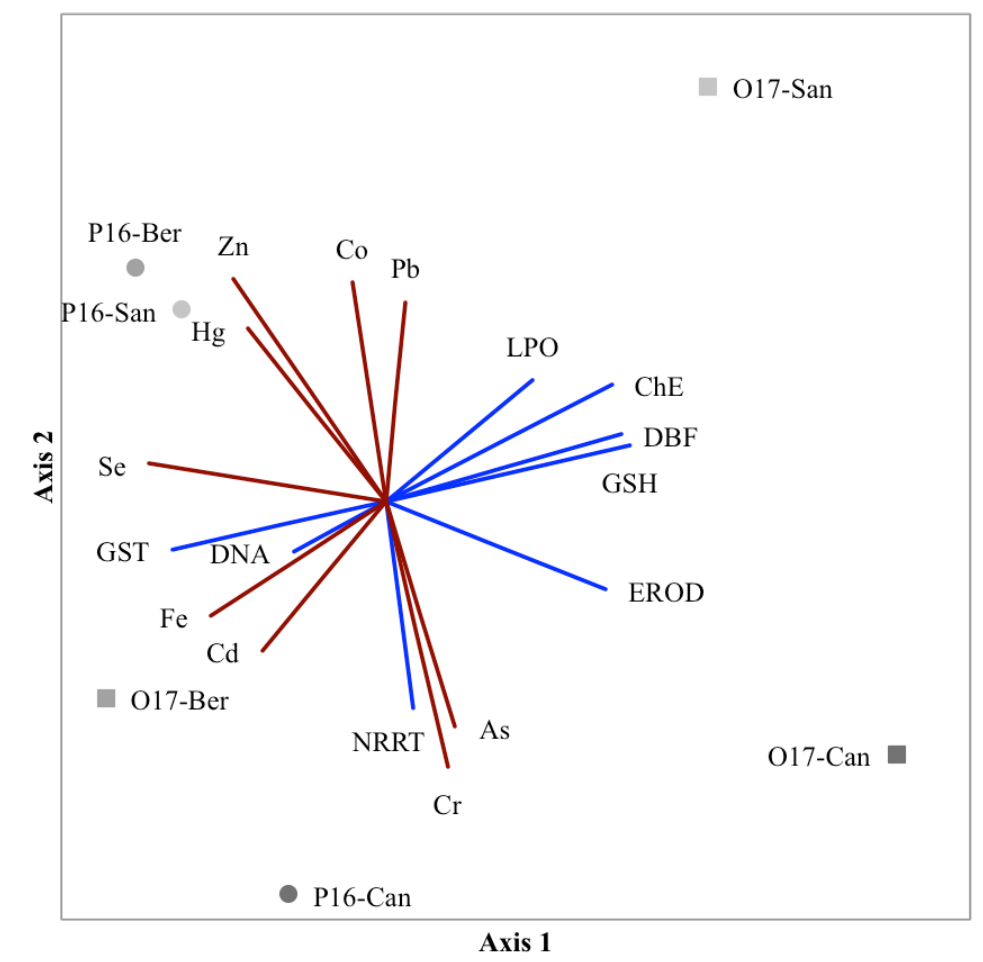

Figura 30. Ordenação dos resultados (loadings e scores) da análise de componentes principais baseada nos dados de bioacumulação de metais (vermelho), biomarcadores bioquímicos e físiológico (azul) obtidos para ostras C. brasiliana coletadas durante a primavera/2016 e o outono/2017. 


\section{Discussão}

De acordo com os tamanhos encontrados por diversos autores em bancos naturais de mexilhões P. perna (Henriques et al., 2004; Henriques \& Casarini, 2009) e ostras C. brasiliana (Galvão et al., 2009; Pereira et al., 2001a) do litoral paulista, os dados de morfometria dos mexilhões e ostras utilizados nas diferentes análises (Figura 16) demonstram homogeneidade entre as diferentes populações amostradas, independentemente das estações do ano.

Em decorrência da grande quantidade de dados gerados, os resultados serão primeiramente discutidos separados, considerando as campanhas realizadas, os organismos analisados, as diferentes análises realizadas, os pontos de coleta e as estações do ano amostradas neste estudo. Posteriormente, será apresentada uma discussão a partir da integração dos resultados obtidos ao longo de todo o trabalho.

\subsection{Campanha de 2008/09}

\subsubsection{Mexilhões P. perna}

O papel principal das respostas de biomarcadores na avaliação da qualidade ambiental é determinar se os mecanismos metabólicos e fisiológicos dos organismos presentes em um ambiente específico estão normais. Em relação às respostas do sistema MFO, as atividades de EROD e DBF medidas nos mexilhões coletados na primavera de 2008 apresentaram indução da atividade enzimática de DBF para os organismos da Cocanha e de Itaipu. Esta enzima, ligada à família CYP3A4, tem sido associada ao metabolismo de produtos farmacêuticos, geralmente presentes em efluentes domésticos (Crespi et al., 1997; Stresser et al., 2000). Gagné et al. (2007), ao avaliarem os efeitos de esgotos urbanos sobre mexilhões de água doce (Elliptio complanata), atribuíram a indução de EROD e DBF à presença de fármacos e esteroides nestes efluentes.

Quanto à enzima de conjugação (fase II do metabolismo), observamos inibição de GST na Cocanha e, concomitantemente, indução em Palmas e Itaipu na primavera de 2008. A inibição da atividade desta enzima pode ser explicada pela exposição a misturas de contaminantes, uma vez que diferentes contaminantes podem ter efeitos opostos e o saldo pode ser "sem efeito" (Lionetto et al., 2003; Monteiro et al., 2007). Por outro lado, o aumento da sua atividade tem sido associado à exposição a contaminação por compostos orgânicos (Aguirre-Martínez et al., 2013; Pereira et al., 2011). 
No que diz respeito ao sistema antioxidante, GSH é um tripeptídeo reduzido que pode reagir diretamente com ROS ou servir como substrato para enzimas antioxidantes (Regoli \& Giuliani, 2014; van Welie et al., 1992). Neste processo, ele é temporariamente transformado na sua forma oxidada (GSSG), principalmente em situações de estresse ou presença de xenobióticos. Dessa forma, seus teores intracelulares refletem o equilíbrio estável entre sua síntese e perda (Kovačević et al., 2008). No presente estudo, os níveis de GSH foram menores na Cocanha durante a primavera de 2008. Cossu et al. (2000) reportaram a indução de glutationa redutase (GR) e glutationa peroxidase (GPx) (enzimas relacionadas ao sistema antioxidante) e a diminuição dos níveis de GSH em bivalves de água doce Unio tumidus expostos a contaminação por metais, HPAs e PCBs.

Analisando os biomarcadores de efeito, observa-se aumento de efeitos peroxidativos na Cocanha e danos genotóxicos na Cocanha e em Itaipu na primavera de 2008. Estes resultados estão de acordo com o observado nas outras fases, as quais indicam que os organismos possivelmente estejam lidando com algum tipo de contaminação. A geração adicional de ROS em decorrência dos processos de detoxificação podem esgotar as defesas antioxidantes, tornando-as incapazes de prevenir danos peroxidativos e genotóxicos (Fernández et al., 2010).

Em relação às respostas bioquímicas obtidas no verão de 2009, observa-se apenas forte inibição da atividade enzimática de ChE tanto em Palmas quanto em Itaipu. A ação inibitória de pesticidas organofosforados e carbamatos sobre a atividade desta enzima tem sido reportada por diversos estudos (Galloway et al., 2002; Lionetto et al., 2013; Oliveira et al., 2015).

De maneira geral, as respostas medidas durante a primavera de 2008 foram algumas ordens de grandeza maiores do que nas outras estações para os organismos de todos os pontos de coleta. O mesmo foi observado nesta época do ano por Pereira et al. (2011), que avaliaram uma bateria de biomarcadores em mexilhões $P$. perna coletados na Cocanha e transplantados para as mesmas áreas na Baía de Santos. Segundo os autores, a exacerbação das respostas fisiológicas dos organismos pode estar relacionada ao seu ciclo reprodutivo, uma vez que durante a primavera eles estão em um período de intensa gametogênese. Além disso, estas respostas também podem estar relacionadas às maiores temperaturas da água que ocorrem na primavera (Wilhelm Filho et al., 2001).

As respostas bioquímicas medidas em mexilhões coletados durante a primavera de 2008 demonstram que os organismos da Cocanha apresentaram pior condição, uma 
vez que podem ser observadas induções nas atividades enzimáticas de EROD (sem diferença significativa em relação aos outros pontos) e DBF (maior que em Palmas), inibição de GST e GSH e aumento de LPO e DNA. A partir deste conjunto de respostas, é possível inferir que estes organismos sofrem efeitos peroxidativos e genotóxicos em função da exposição a substâncias orgânicas e metais, uma vez que houve ativação da fase I da detoxificação, além de esgotamento da fase II do metabolismo e do sistema antioxidante, geralmente associados a estes tipos de contaminantes (Aguirre-Martínez et al., 2013; Bebianno et al., 2007; Farombi et al., 2007; Gagné et al., 2007). Catharino et al. (2012) analisaram a bioacumulação de metais em mexilhões coletados nas mesmas áreas e nos mesmos períodos que os organismos aqui analisados. Os autores encontraram altas concentrações de $\mathrm{As}, \mathrm{Fe}, \mathrm{Hg}, \mathrm{Cd}, \mathrm{Cr}$ e Se nos tecidos dos mexilhões da Cocanha e relacionaram estes resultados às atividades decorrentes do turismo e à existência de ocupações irregulares na região.

Com base no padrão de respostas bioquímicas exibido pelos organismos coletados em Palmas, é provável que eles estejam expostos a diversas classes de contaminantes, incluindo metais e fármacos. Antidepressivos e metais mostraram inibir a atividade de CYP3A4 (i.e. DBF) (Martín-Díaz et al., 2009; Ricciardi et al., 2006; Thibaut et al., 2006). A fase II do metabolismo, representada pela atividade de GST, também pode estar relacionada ao metabolismo de compostos orgânicos e metais (Monteiro et al., 2007; Roméo et al., 2003), assim como o sistema antioxidante. Tais contaminantes também são capazes de induzir a síntese de GSH como resposta à superprodução de ROS resultante de seu metabolismo (Franco et al., 2006; Sparks et al., 2018). De acordo com os resultados da PCA, estão também relacionados à produção de efeitos de LPO e DNA, apesar destes biomarcadores não apresentarem diferença significativa em relação aos outros pontos. Durante o verão de 2009, observa-se forte inibição da atividade de $\mathrm{ChE}$, apontando para possível introdução de poluentes orgânicos, principalmente pesticidas, e metais (Calisi et al., 2011; Galloway et al., 2002; Lionetto et al., 2003).

No caso dos organismos de Itaipu, os biomarcadores analisados indicam que os organismos estejam lidando com contaminação difusa. Isso porque há ativação de EROD e DBF (mesmo que sem diferença significativa), enzimas geralmente relacionadas ao metabolismo de compostos orgânicos (van der Oost et al., 2003). Camargo et al. (2015) reportaram toxicidade dos sedimentos coletados nesta região devido à presença de amônia e componentes orgânicos, provavelmente HPAs, 
detergentes e fármacos, advindos do despejo de esgotos domésticos. Além disso, considerando a indução da atividade de GST, os altos níveis de GSH e os efeitos neurotóxicos e genotóxicos, é possível inferir que os principais contaminantes a que os mexilhões de Itaipu estão expostos são metais, especialmente Co, Zn e Se. A bioacumulação de metais nos tecidos dos organismos é capaz de induzir reações que geram ROS, culminando num estresse oxidativo e na consequente ativação de mecanismos de defesa (Farombi et al., 2007). Durante o verão de 2009, houve inibição de ChE, a qual está geralmente associada à presença de pesticidas (Capolupo et al., 2016; Valbonesi et al., 2003).

Levando em consideração os resultados da PCA, é possível identificar o agrupamento de Palmas e Itaipu de acordo com a estação do ano, enquanto a Cocanha não seguiu este padrão. O primeiro fator correlacionou todos os biomarcadores bioquímicos entre si, sendo que todos os pontos na primavera de 2008 estiveram associados a estas variáveis (scores positivos). Isso evidencia a temporalidade da fisiologia dos mexilhões, cujos níveis se apresentaram exacerbados nesta época do ano. Por outro lado, Palmas e Itaipu durante o verão de 2009 e o inverno de 2009 estiveram inversamente associados a este fator (scores negativos), juntamente com Co, o que pode ser explicado pelos altos teores deste elemento nestes pontos.

Ao segundo eixo se correlacionaram a maioria dos metais, sendo que todas as estações estudadas na Cocanha estiveram associadas a estas variáveis (scores positivos). Isso se deve ao fato de os organismos coletados neste ponto terem apresentado as maiores concentrações destes elementos em todas as campanhas. A Cocanha vem sofrendo maior degradação ambiental devido ao incremento do turismo e às ocupações irregulares, as quais aumentam a carga de esgotos (tratados e não tratados) no ambiente marinho (Catharino et al., 2012).

\subsubsection{Ostras C. brasiliana}

As respostas bioquímicas medidas nas ostras coletadas nas campanhas ao longo de 2008/09 demonstram ativação da fase I de detoxificação para os organismos de Cananéia e Santos durante a primavera de 2008 e o verão de 2009. As atividades enzimáticas de EROD e DBF estão associadas à metabolização principalmente de contaminantes orgânicos (Maranho et al., 2012; Martín-Díaz et al., 2008; Pereira et al., 2016). Em relação à fase II de conjugação, houve diminuição da atividade enzimática de GST em Cananéia e Santos durante a primavera de 2008. Estas enzimas apresentam 
respostas bifásicas dependentes do tempo, ou seja, são moduladas de acordo com a intensidade e a duração da exposição à contaminação (Bocchetti et al., 2008). Já o aumento de GSH com concomitantes efeitos peroxidativos e genotóxicos em Cananéia durante a primavera de 2008 e o verão de 2009 sugerem exaustão das defesas antioxidantes (Farombi et al., 2007). As baixas atividades de ChE em Cananéia durante a primavera de 2008 e o verão de 2009 podem ser resultado da exposição à contaminação por metais e pesticidas. Particularmente, duas classes de pesticidas são capazes de afetar a atividade de ChE: compostos organofosforados e carbamatos, os quais são principalmente utilizados como inseticida e herbicida, respectivamente (Payne et al., 1996). Adicionalmente, Frasco et al. (2005) demonstraram ação inibitória de metais sobre a atividade desta enzima. A bacia hidrográfica do Rio Ribeira de Iguape tem histórico de contaminação por metais em função das antigas atividades de mineração (Mahiques et al., 2009), tendo sido encontradas altas concentrações de Cd, As e Cr nas ostras desta região (Catharino et al., 2015). A região é também importante área agrícola do estado de São Paulo, cujos efluentes são despejados no rio, afetando indiretamente os organismos que habitam o estuário (Gusso-Choueri et al., 2015).

Durante a primavera de 2008 e o verão de 2009 é possível observar um gradiente de respostas entre os pontos. Em ambas as estações do ano verifica-se que as ostras de Bertioga apresentaram melhor condição fisiológica. Ainda, Cananéia apresentou maior nível de alterações em praticamente todas as fases do metabolismo. $\mathrm{Na}$ fase I, EROD foi induzida na primavera de 2008, enquanto DBF apresentou maior atividade na primavera de 2008 e no verão de 2009. Houve inibição de GST e aumento de GSH durante a primavera de 2008. Além disso, efeitos peroxidativos, genotóxicos e neurotóxicos ficaram evidentes em ambas as estações.

Este conjunto de respostas bioquímicas pode ser indicativo da exposição destes organismos a contaminação por despejo de esgotos. Gagné et al. (2007) observaram respostas similares em mexilhões de água doce expostos a esgotos urbanos. Nesta época do ano, principalmente durante o verão, ocorre o aumento significativo do volume de esgotos descartados nos sistemas costeiros em consequência do aumento populacional em períodos de veraneio (Abessa, 2002; CETESB, 2017), o que demonstra o grande impacto do turismo sobre a qualidade ambiental dos ecossistemas costeiros (Davenport \& Davenport, 2006).

Durante o inverno de 2009, os organismos que apresentaram pior condição fisiológica foram aqueles coletados em Santos. Analisando todas as respostas ativadas 
nas diferentes estações do ano estudadas, é possível inferir que este ponto está sujeito à exposição crônica a intensa contaminação. Isso porque houve indução de EROD e DBF em todas as estações, enzimas relacionadas principalmente ao metabolismo de esteroides e fármacos (Gagné et al., 2007) e consideráveis níveis de efeitos genotóxicos e neurotóxicos (apesar de não haver diferença significativa em relação aos outros pontos). Além disso, ficam evidentes respostas de GST e GSH, com efeitos peroxidativos, na primavera de 2008. Isso é corroborado pelos resultados obtidos por Catharino et al. (2015), que realizaram ensaio de NRRT e análise de bioacumulação de metais em ostras C. brasiliana coletadas nas mesmas estações e nos mesmos pontos. Os autores observaram que a maioria das altas concentrações dos elementos analisados ocorreram em Santos e os piores NRRT também, levando-os à mesma conclusão.

A integração das respostas bioquímicas com dados químicos através da PCA suportam estes resultados. O primeiro fator demonstrou de forma significativa a relação entre EROD e todos os metais (exceto As), sendo representativo de Santos no verão de 2009 e no inverno de 2009 (scores negativos). Isso corrobora a exposição destes organismos a intensa contaminação, apontando para a presença de efluentes domésticos e industriais, que despejam grandes volumes de substâncias orgânicas (relacionadas à atividade de EROD) e metais no Sistema Estuarino de Santos (Berbel et al., 2015; Cesar et al., 2007; Hortellani et al., 2008; Yogui et al., 2003).

$\mathrm{O}$ segundo fator demonstrou correlação entre os biomarcadores bioquímicos (exceto EROD, GST e ChE), sendo representativo para Cananéia na primavera de 2008 e no verão de 2009 e Santos na primavera de 2008 (scores negativos). Este resultado dá suporte à constatação de que Cananéia estiveram com a saúde prejudicada nestas estações do ano, apresentando respostas similares a Santos. Por outro lado, este fator foi representativo para Cananéia do inverno de 2009 e Bertioga em todas as estações do ano (scores positivos), estando relacionado a ChE. Estes pontos foram os que apresentaram melhores condições fisiológicas e menores teores de metais.

\subsection{Campanha de 2016/17}

\subsubsection{Mexilhões P. perna}

Levando em consideração a importância dos bivalves para o consumo humano e os limites máximos de tolerância estabelecidos pela legislação brasileira para a categoria de outros alimentos, alimentos sólidos e qualquer alimento (Brasil, 1965), é possível verificar que os teores de Cr em Palmas durante o outono de 2017 estiveram 
acima destes limites $\left(0,1 \mu \mathrm{g} \mathrm{g}^{-1}\right)$, bem como os teores de Se em todos os pontos na mesma campanha e na Cocanha na primavera de $2016\left(0,3 \mu \mathrm{g} \mathrm{g}^{-1}\right)$. Além disso, as concentrações de As para todos os pontos em ambas as campanhas estudadas estiveram acima dos limites de tolerância para moluscos bivalves $\left(1,0 \mu \mathrm{g} \mathrm{g}^{-1}\right)$ (Brasil, 2013). Para os elementos $\mathrm{Cd}, \mathrm{Hg}, \mathrm{Pb}$ e $\mathrm{Zn}$, os teores medidos estiveram sempre abaixo dos limites máximos estabelecidos pela legislação. Não existem informações sobre os limites máximos permitidos para $\mathrm{Fe}$ e Co em produtos alimentícios na legislação nacional.

Os resultados obtidos para $\mathrm{Cd}, \mathrm{Hg}$ e $\mathrm{Zn}$ em Palmas e Itaipu foram similares aos valores reportados por Pereira et al. (2002) e por Pereira et al. (2012), que determinaram as concentrações de metais em mexilhões $P$. perna coletados na Região Metropolitana da Baixada Santista (RMBS). Ainda, para os elementos $\mathrm{Hg}$ e $\mathrm{Zn}$, os teores obtidos em Palmas e Itaipu são semelhantes aos resultados obtidos por Lamparelli et al. (2001) para a Baía de Santos. Por outro lado, os autores encontraram menores concentrações de $\mathrm{Cd}$ e $\mathrm{Pb}$ e maiores valores de $\mathrm{Cr}$ em relação ao medido no presente estudo.

Catharino et al. (2012) monitoraram a contaminação inorgânica por metais em mexilhões $P$. perna coletados na RMBS e na Praia da Cocanha em todas as estações do ano ao longo de um ano e observaram concentrações similares de $\mathrm{Cd}, \mathrm{Hg}$, Se, Co e $\mathrm{Zn}$ para todos os pontos de coleta. Os autores também constataram as maiores concentrações de $\mathrm{As}, \mathrm{Fe}, \mathrm{Hg}, \mathrm{Cd}$ e Se na Cocanha em todas as campanhas amostradas. Isso concorda parcialmente com o encontrado neste estudo, em que as maiores concentrações de $\mathrm{Cd}, \mathrm{Hg}$, Se e $\mathrm{Zn}$ ocorreram na Cocanha em ambas as estações estudadas. Ainda, os organismos deste local apresentaram os maiores teores de $\mathrm{Pb}$ e $\mathrm{As}$ apenas no outono de 2017 e de Fe apenas na primavera de 2016.

Os valores encontrados por Catharino et al. (2012) para Fe em Palmas e Itaipu (12,0-26,0 $\left.\mu \mathrm{g} \mathrm{g}^{-1}\right)$ são similares com o encontrado aqui (10,0-28,0 $\left.\mu \mathrm{g} \mathrm{g}^{-1}\right)$. Entretanto, os organismos coletados na Cocanha apresentaram menores concentrações deste elemento nas campanhas realizadas neste estudo $\left(20,0-25,0 \mu \mathrm{g} \mathrm{g}^{-1}\right)$ em comparação ao estudo anterior $\left(46,0-89,0 \mu \mathrm{g} \mathrm{g}^{-1}\right)$. Contrariamente, os teores de Cr para a Cocanha tanto aqui $\left(0,085 \mu \mathrm{g} \mathrm{g}^{-1}\right)$ quanto no estudo acima citado $\left(0,068-0,136 \mu \mathrm{g} \mathrm{g}^{-1}\right)$ são comparáveis. Já em Palmas e Itaipu os autores não detectaram valores significativos deste elemento (i.e. $<0,016 \mu \mathrm{g} \mathrm{g}^{-1}$ ), enquanto no presente estudo foram encontrados altos níveis de $\mathrm{Cr}\left(0,053-0,130 \mu \mathrm{g} \mathrm{g}^{-1}\right)$, inclusive acima do limite estabelecido na legislação vigente para consumo humano (apenas em Palmas no outono de 2017). Ainda 
assim, os valores de Cr não foram tão elevados quanto os reportados por Pereira et al. (2002) e Pereira et al. (2012). Além disso, o elemento As também apresentou concentrações ligeiramente mais elevadas no presente estudo $\left(1,78-4,90 \mu \mathrm{g} \mathrm{g}^{-1}\right)$ comparado ao encontrado por Catharino et al. (2012) $\left(0,86-3,23 \mu \mathrm{g} \mathrm{g}^{-1}\right)$.

É importante destacar que as concentrações de $\mathrm{Pb}$ medidas neste estudo em todos os pontos e todas as estações $\left(0,090-1,10 \mu \mathrm{g} \mathrm{g}^{-1}\right)$ diferiram bastante do encontrado por estudos anteriores nos mesmos locais. Catharino et al. (2012) reportaram valores entre $0,018 \mu \mathrm{g} \mathrm{g}^{-1}$ e $0,098 \mu \mathrm{g} \mathrm{g}^{-1}$, sendo que as maiores concentrações estiveram presentes na Cocanha na maioria das estações estudadas. Em outro estudo com mexilhões $P$. perna da Praia da Cocanha transplantados para locais na RMBS em todas as estações do ano ao longo de um ano (Pereira et al., 2012), os valores de $\mathrm{Pb}$ variaram de $0,025 \mu \mathrm{g} \mathrm{g}^{-1}$ a $0,070 \mu \mathrm{g} \mathrm{g}^{-1}$ em pontos equivalentes a Palmas e Itaipu, sendo que os organismos coletados na Cocanha apresentaram valores abaixo do limite de detecção (i.e. $<0,011 \mu \mathrm{g} \mathrm{g}^{-1}$ ). Ademais, as concentrações de $\mathrm{Pb}$ medidas nos organismos coletados em Palmas (primavera de 2016 e outono de 2017;0,35-0,65 $\mu \mathrm{g} \mathrm{g}^{-1}$ ) e em Itaipu (primavera de 2016;0,35 $\mu \mathrm{g} \mathrm{g}^{-1}$ ) foram maiores do que os valores reportados por Pereira et al. (2002) (0,14-0,18 $\left.\mu \mathrm{g} \mathrm{g}^{-1}\right)$.

Observando as diferenças entre as estações do ano, é possível identificar que a maioria dos elementos (i.e. $\mathrm{Hg}$, Fe, Se, Co e $\mathrm{Zn}$ ) apresentou maior concentração durante o outono de 2017 para todos os pontos. Em estudos anteriores temporais na mesma região, o inverno e o outono foram as estações do ano que apresentaram os maiores valores de contaminação por metais (Catharino et al., 2012; Pereira et al., 2012). Além disso, Itaipu foi o ponto em que as concentrações de menor quantidade de elementos diferiram entre as estações do ano, indicando a introdução contínua de contaminantes.

Em relação às respostas do sistema MFO, as atividades de EROD e DBF medidas nos mexilhões não apresentaram resposta significativa durante a primavera de 2016; porém, durante o outono de 2017, apresentaram significativa redução em Palmas e Itaipu relativo à Cocanha. Diversos autores demonstraram que a presença frequente de metais divalentes em efluentes domésticos e industriais (e.g. mercúrio e cobre), que interferem no ciclo de indução de CYP1A através da ligação aos grupos tiol (-SH) (Viarengo et al., 1997), em conjunto com contaminantes emergentes (e.g. pesticidas), os quais se ligam ao grupo heme das CYP1A (Levine et al., 1997), levam à inibição da atividade de EROD. Díaz-Garduño et al. (2018), ao avaliarem respostas bioquímicas em solhas (Solea senegalensis) expostas a efluentes urbanos fotobiotratados, relacionaram a 
inibição do metabolismo mediado pela família de proteínas CYP à presença de compostos farmacêuticos.

Infelizmente, poucos estudos sobre este efeito em bivalves estão disponíveis. Ricciardi et al. (2006) sugerem um possível mecanismo de interferência na atividade de EROD em mexilhões-zebra (Dreissena polymorpha) causado pela contaminação por metais-traço. Também, Monari et al. (2008) atribuem efeitos negativos sobre a expressão de proteínas CYP1A em vôngoles (Chamelea gallina) à exposição dos organismos a antibióticos.

Por outro lado, deve-se considerar que houve aumento da atividade de EROD e DBF nos organismos coletados na Cocanha no outono de 2017 em relação às respostas medidas na primavera de 2016. Diversos estudos tem atribuído a indução da atividade destas enzimas ao metabolismo de fármacos (Aguirre-Martínez et al., 2013; Gagné et al., 2007; Pereira et al., 2012). Além disso, relação direta entre o aumento de CYP450 e concentrações ambientais de HPAs e PCBs também tem sido demonstrada (Bebianno et al., 2007; Cajaraville et al., 2000).

Quanto às atividades enzimáticas relacionadas à fase II do metabolismo, foi observado redução da atividade de GST em Palmas e Itaipu durante a primavera de 2016. Al-Ghais \& Ali (1999) demonstraram a ação inibitória de organotinas sobre a atividade desta enzima em peixes. Em mexilhões dulcícolas (Lamellidens marginalis), foi observada supressão de GST após exposição persistente a arsenito (Chakraborty et al., 2010). Além disso, resultados obtidos por Bocchetti et al. (2008) ao estudarem respostas bioquímicas em mexilhões marinhos (Mytilus galloprovincialis) expostos a operações de dragagem de um porto na Itália sugerem que a atividade de GST pode ser modulada pela intensidade e duração da perturbação química. Ou seja, em situações de exposição por longos períodos ou maior intensidade, a perturbação oxidativa pode exceder a eficiência das respostas metabólicas.

Contrariamente, a atividade de GST em Palmas e Itaipu durante o outono de 2017 foi maior em relação aos organismos-referência. O aumento da atividade enzimática de GST em invertebrados aquáticos já foi reportada por diversos estudos (Gagné et al., 2007; Martín-Díaz et al., 2009), inclusive alguns realizados na mesma área (Maranho et al., 2012; Pereira et al., 2014). Esta alteração tem sido relacionada à presença de poluentes orgânicos (Aguirre-Martínez et al., 2013; Maranho et al., 2012). Vale ressaltar que, nesta mesma estação do ano, a atividade desta enzima na Cocanha foi menor em relação ao observado na primavera de 2016. Este resultado pode estar 
relacionado à inibição desta atividade enzimática em função da presença de contaminação por metais e HPAs (Bebianno et al., 2007; Chakraborty et al., 2010; Farombi et al., 2007).

O sistema antioxidante, por sua vez, demonstrou aumento dos níveis de GSH na Cocanha no outono de 2017, diferindo significativamente dos outros dois pontos na mesma época e do observado durante a primavera de 2016 para todos os pontos analisados. Este resultado é concordante com o observado para GST, que apresentou baixa atividade enzimática na Cocanha e alta atividade em Palmas e Itaipu na mesma campanha. Isso pode ser indicativo da presença de poluentes nestes últimos pontos, uma vez que muitas substâncias tem a capacidade de diminuir os níveis ou a eficiência de GSH em remover ROS intracelular (Regoli \& Giuliani, 2014; Viarengo et al., 1997).

Em relação aos efeitos da exposição dos mexilhões à contaminação, foi possível observar que os níveis de LPO durante o outono de 2017 foram maiores na Cocanha, diferindo significativamente do medido em Palmas e Itaipu. Este resultado concorda com o obtido para GST e GSH nesta época do ano, os quais indicam aumento das atividades de detoxificação e antioxidantes em Palmas e Itaipu, prevenindo peroxidação lipídica das membranas.

Os efeitos sobre o DNA ficaram evidentes no outono de 2017 apenas para Itaipu. Entretanto, houve aumento da quantidade de strand breaks medidos em todos os pontos no outono de 2017 em relação à primavera de 2016. As alterações no DNA promovidas por agentes químicos (ou seus metabólitos) incluem quebras de cadeia simples e duplas. Elas também podem ser induzidas por uma interação com ROS ou como consequência de processos de apoptose ou necrose (Viarengo et al., 2007). A capacidade reduzida de neutralizar oxirradicais (evidenciada aqui pelos baixos níveis de GSH) tem papel fundamental na toxicidade oxidativa de poluentes, como amplamente demonstrado pelo aumento da taxa de alterações celulares, como a perda de integridade do DNA (Ameur et al., 2012; Bocchetti et al., 2008; Guidi et al., 2010).

Efeitos neurotóxicos foram detectados em Palmas e Itaipu na primavera de 2016 e no outono de 2017. A inibição de ChE tem sido considerada um biomarcador de efeitos decorrentes da exposição a pesticidas (i.e. organofosforados e carbamatos) e metais pesados (Galloway et al., 2002; Lionetto et al., 2003). O fato desta resposta ter sido evidente em ambas as estações pode ser indicativo da presença de fontes de contaminação constantes ao longo do ano. 
Também foi possível observar que, na Cocanha, a atividade de ChE foi maior durante o outono de 2017. Alguns autores têm sugerido que a indução da atividade desta enzima pode estar relacionada a processos de apoptose e morte celular (Du et al., 2015; Zhang \& Greenberg, 2012; Zhang et al., 2002).

Quanto aos resultados relacionados à estabilidade da membrana lisossômica, o curto tempo de retenção do corante vermelho neutro (NRRT) pode ser devido à exposição dos organismos a poluentes, uma vez que lisossomos são organelas que retêm uma grande variedade de substâncias orgânicas e inorgânicas e, devido à sua capacidade de acumular tais compostos, tem sido identificados como alvo de efeitos adversos causados por diferentes contaminantes (Hwang et al., 2002).

Entretanto, a baixa integridade da membrana lisossômica dos mexilhões provenientes da área considerada referência de qualidade durante a primavera de 2016 pode não estar vinculada estritamente à contaminação química. Isso porque o vermelho neutro é um indicador de estresse fisiológico não-específico, podendo o estresse ser desencadeado por uma variedade de fatores além da contaminação química (Fang, 2007). Esta resposta pode estar relacionada à ocorrência de um evento de floração de microalgas em um período imediatamente anterior à coleta destes organismos (CETESB, 2017). Apesar destes eventos serem pontuais, as toxinas produzidas por microalgas (i.e. cianobactérias, dinoflagelados) tem o potencial de causar distúrbios na saúde dos organismos expostos a elas (Gorbi et al., 2012; Hégaret et al., 2011; Lehtonen et al., 2003; Manfrin et al., 2012). Em estudo com mexilhões naturalmente expostos a toxinas algais, Buratti et al. (2013) registraram baixos NRRT, juntamente com alterações sobre a atividade enzimática de catalase (CAT) e GST, indicando o início de uma grave síndrome de estresse. Os autores argumentam que tais toxinas podem afetar vias fisiológicas, incluindo a funcionalidade de hemócitos, a expressão gênica e a sinalização celular.

O NRRT nos mexilhões da Cocanha foi maior no outono de 2017 em relação ao obtido na campanha anterior. Entretanto, os organismos provenientes dos outros dois pontos (Palmas e Itaipu) mantiveram os mesmos tempos, o que dá suporte às evidências de exposição destas populações a fontes de contaminação constantes ao longo do ano, afetando negativamente a saúde dos organismos ali presentes.

De acordo com Davies et al. (2012), respostas biológicas devem ser avaliadas em relação a determinados critérios, os quais orientam a interpretação dos dados em termos de sua significância ambiental. Neste sentido, a OSPAR e o ICES 
desenvolveram critérios de avaliação para medições de efeitos biológicos, baseados em resultados obtidos por diversos estudos (Davies et al., 2012; Webster et al., 2009). O critério BAC (background assessment criteria) pode ser definido como um nível basal de resposta, acima do qual os organismos podem ser considerados saudáveis. O critério EAC (environmental assessment criteria), por sua vez, representa níveis de resposta abaixo dos quais seriam esperados efeitos em níveis maiores de organização biológica.

Ambos os critérios foram estabelecidos baseados em estudos com Mytilus sp., mexilhões comumente encontrados em latitudes temperadas. Entretanto, diversos estudos tem demonstrado que NRRT difere entre espécies de zonas temperadas comparado a zonas tropicais, uma vez que o corante é retido nos lisossomos por períodos mais curtos devido às altas temperaturas dos trópicos (Ortega et al., 2018; Pereira et al., 2011). Ortega et al. (2018) sugerem que mexilhões $P$. perna devem ser considerados saudáveis quando NRRT $\geq 60 \mathrm{~min}$; estressados, mas compensando se NRRT $<60$ min e $\geq 30$ min; e severamente estressados quando NRRT $\leq 30$ min (Figura 31). Considerando estes parâmetros, os mexilhões coletados na primavera de $2016 \mathrm{em}$ todos os pontos podem ser considerados estressados, mas compensando. Já no outono de 2017, os organismos da Cocanha estariam saudáveis, enquanto aqueles coletados em Palmas e Itaipu ainda seriam considerados estressados, mas compensando.

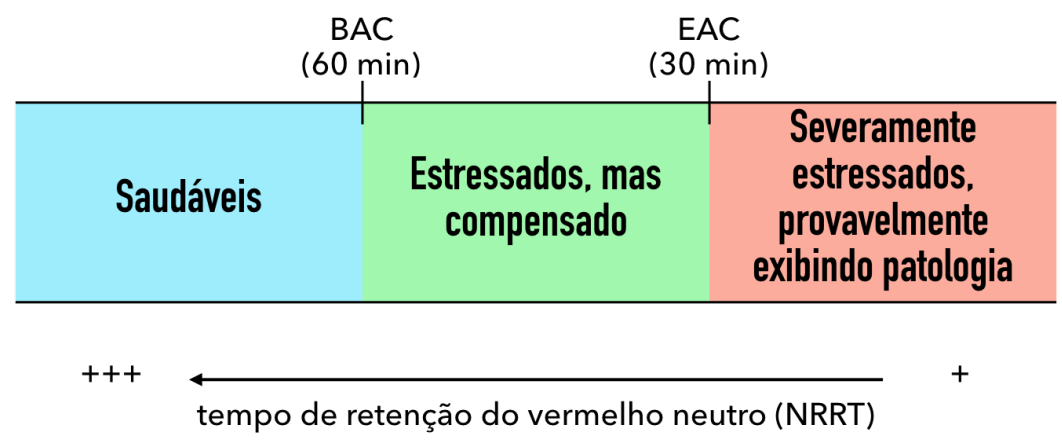

Figura 31. Critérios BAC e EAC para a estabilidade de membrana lisossomal medida como tempo de retenção do vermelho neutro (Ortega et al., 2018). Adaptado de Martínez-Gómez et al. (2015).

Além disso, deve-se levar em consideração que a fase de desova provoca alterações nas condições fisiológicas de bivalves marinhos, possivelmente atuando como um fator de estresse interno para a integridade dos lisossomos (Cho \& Jeong, 2005). Este fator pode ter influenciado as respostas observadas durante a primavera de 2016, quando ocorre o aumento das atividades metabólicas em função do ciclo 
reprodutivo dos mexilhões $P$. perna, o que demanda a mobilização de lipídios e a síntese de proteínas para a gametogênese (Wilhelm Filho et al., 2001).

A PCA permite a visualização mais integrada destes resultados, facilitando sua interpretação. O primeiro fator demonstrou de forma significativa a relação da maioria dos biomarcadores bioquímicos (GST inversamente) ao NRRT e à presença de alguns metais. A Cocanha no outono de 2017 apresentou associação negativa significativa com este fator, o que pode ser explicado pelas altas concentrações de $\mathrm{Cd}, \mathrm{Hg}, \mathrm{As}$, Se e $\mathrm{Zn}$ nesta campanha, e pelas alterações em todos as fases do metabolismo de xenobióticos. Por outro lado, a campanha da primavera de 2016 neste mesmo ponto esteve associada a este fator, porém de maneira positiva. Apesar de os organismos terem sido coletados no mesmo ponto, as diferenças entre as estações do ano estudadas pode ser indicativo da presença de contaminação de acordo com a época do ano.

O segundo fator demonstrou relação de GSH e LPO com os teores de Pb, e de DNA com Cr, Fe, Co e Zn. Palmas e Itaipu se associaram a este fator, sendo que as coletas do outono de 2017 estiveram correlacionadas positivamente, enquanto a primavera de 2016 apresentou scores negativos. Ou seja, apesar da presença constante de contaminação na Baía de Santos, as características desta contaminação seguem uma temporalidade, uma vez que o perfil de contaminação na primavera é diferente do outono, produzindo respostas biológicas diferentes. Ambos os pontos sofrem influência das águas provenientes do interior dos Estuários de Santos (Palmas) e São Vicente (Itaipu), estando sujeitos à contaminação oriunda das indústrias, lixões irregulares, ocupações irregulares e disposição de esgotos sanitários in natura nestes corpos d'água (Abessa et al., 2005a; C. C. Martins et al., 2008; Oliva, 2003). Além disso, o emissário submarino de Santos é uma das principais fontes de alteração e degradação da qualidade ambiental desta área (Abessa et al., 2005a; CETESB, 2007; Subtil et al., 2012). Destaca-se a associação de $\mathrm{Pb}$ ao segundo fator, demonstrando a importância deste elemento como contaminante para os organismos desta região (principalmente na primavera). Choueri et al. (2009) identificaram este elemento como um poluente-chave no Porto de Santos, cujas atividades influenciam a contaminação na Baía de Santos.

\subsubsection{Ostras C. brasiliana}

Levando em consideração os limites máximos de tolerância estabelecidos pela legislação brasileira para moluscos bivalves destinados ao consumo humano (Brasil, 2013), é possível observar que apenas $\mathrm{Zn}$ esteve acima destes parâmetros $\left(50 \mu \mathrm{g} \mathrm{g}^{-1}\right)$ 
para todos os pontos de coleta em ambas as estações do ano. É importante ressaltar que as ostras acumulam naturalmente este elemento a um nível de algumas centenas de microgramas por grama de tecido úmido (McCulloch et al., 1989), estando relacionado às funções reprodutivas e ao estágio de maturação gonadal destes organismos (PáezOsuna et al., 1995). Entretanto, as concentrações obtidas para Palmas e Itaipu em ambas as estações estudadas são muito elevadas, sendo maiores que os níveis reportados por Silva et al. (2001) para ostras coletadas no Rio Potengi (RN), cujos níveis de metais tóxicos foram considerados pelos autores com potencial risco à saúde humana. Os demais elementos estiveram sempre abaixo dos limites máximos estabelecidos pela legislação nacional.

Em um estudo anterior, Catharino et al. (2015) analisaram a bioacumulação de metais em ostras C. brasiliana coletadas nos Estuários de Cananéia, de Santos e de Bertioga. Os autores observaram que a maioria das altas concentrações dos elementos ocorreram em Santos (i.e. $\mathrm{Cd}, \mathrm{Hg}, \mathrm{Pb}, \mathrm{Cr}, \mathrm{Fe}, \mathrm{Se}, \mathrm{Co}$ e $\mathrm{Zn}$ ), ao contrário do obtido neste estudo, em que Bertioga foi o local que apresentou a maioria das maiores concentrações (i.e. $\mathrm{Cd}, \mathrm{Hg}$, As, Fe, Se, Co e $\mathrm{Zn}$ ). As concentrações de $\mathrm{Pb}, \mathrm{Hg}$ e $\mathrm{Zn}$ em Bertioga também foram maiores do que os valores apresentados por Pereira et al. (2002), em que os autores analisaram a bioacumulação de $\mathrm{Hg}, \mathrm{Pb}, \mathrm{Cd}, \mathrm{Cu}$ e $\mathrm{Zn}$ em ostras C. brasiliana coletadas em bancos naturais do rio Itaguaré, em Bertioga.

Por outro lado, os teores de $\mathrm{Pb}$ foram maiores nas ostras de Santos, inclusive em níveis mais altos do que o reportado por Catharino et al. (2015), evidenciando que a contaminação do estuário por este elemento permanece e pode ter piorado ao longo do tempo. Ainda, os resultados obtidos para $\mathrm{Hg}$ e $\mathrm{Zn}$ em Santos concordam com o encontrado por Lamparelli et al. (2001) para o Estuário de Santos, em um monitoramento realizado no Sistema Estuarino de Santos e São Vicente.

As ostras de Cananéia apresentaram em ambas as estações do ano estudadas altos níveis de As e de Cr. O Rio Ribeira de Iguape, que desagua no Complexo Estuarino-Lagunar de Cananéia-Iguape-Peruíbe, tem histórico de contaminação por metais devido às antigas atividades de mineração (principalmente de $\mathrm{Ag}, \mathrm{Zn}$ e $\mathrm{Pb}$ ) que ocorriam à montante do rio (interrompidas na década de 1990) (Mahiques et al., 2009). Altas concentrações de metais $(\mathrm{Pb}, \mathrm{Zn}, \mathrm{Cu}, \mathrm{Cr}$ e $\mathrm{As})$ tem sido registradas nas águas e nos sedimentos de fundo e suspensos e na biota (Catharino et al., 2015; Guimarães \& Sígolo, 2008; Gusso-Choueri et al., 2015; Mahiques et al., 2009). 
Analisando as respostas bioquímicas medidas nas ostras coletadas durante a primavera de 2016 e o outono de 2017, podemos identificar alterações nas diversas fases do metabolismo de xenobióticos. Relativo à primavera de 2016, houve indução da atividade de EROD, relacionada à fase I de biotransformação, em Cananéia. Quanto à fase II de conjugação, houve aumento da atividade enzimática de GST em Cananéia e Santos, diferindo significativamente de Bertioga. Enquanto isso, o sistema antioxidante apresentou baixos teores de GSH em todos os pontos. Houve também aumento da quantidade de aductos de DNA em Cananéia e baixa atividade enzimática de ChE para os três pontos coletados.

Ao contrário do esperado, muitas das respostas bioquímicas relacionadas a distúrbios metabólicos estiveram presentes nas ostras coletadas na área considerada referência de qualidade. Estes resultados, em conjunto com o obtido nas análises de metais, em que estes organismos apresentaram as maiores concentrações de $\mathrm{Cd}$, $\mathrm{As}$ e $\mathrm{Cr}$ durante a primavera de 2016 e de $\mathrm{Cr}$ no outono de 2017, apontam para a possível presença de fontes de contaminação no Estuário de Cananéia. Estudos realizados no local demonstraram níveis moderados de metais nos sedimentos, provenientes de fontes antropogênicas (Mahiques et al., 2009), além de metabólitos de metais e HPAs em speixes demersais (bagre-amarelo Cathorops spixii) associada a respostas antioxidantes, estresse oxidativo, neurotoxicidade e genotoxicidade (Gusso-Choueri et al., 2015).

As respostas apresentadas pelas ostras de Santos e Bertioga na primavera de 2016 foram bastante similares, diferindo apenas no que diz respeito à atividade de GST (menor em Bertioga). Isso pode ser indicativo da exposição dos organismos de ambos os locais a contaminantes ambientais. Entretanto, o cenário fisiológico muda no outono de 2017. EROD e DBF, enzimas relacionadas à fase I, demonstraram diminuição de atividade em Santos e Bertioga. A partir desta resposta, juntamente com a indução de GST (fase II) em Bertioga, e o aumento de GSH (sistema antioxidante) e LPO em Santos, é possível inferir que as ostras de Santos e Bertioga estão expostas a diferentes classes de contaminantes. Os efeitos neurotóxicos medidos nestes organismos dão suporte a essa hipótese, uma vez que as ostras de Santos apresentaram indução da atividade de ChE, enquanto em Bertioga houve inibição desta enzima.

O conjunto de respostas observado nas ostras de Santos pode indicar contaminação por compostos orgânicos, principalmente em função da indução da atividade de DBF. As isoenzimas da família CYP3A4 tem sido associadas à metabolização de produtos farmacêuticos em vertebrados (Crespi et al., 1997; Stresser 
et al., 2000). Apesar dos altos níveis de GSH, houve efeitos de peroxidação lipídica, o que pode apontar para insuficiência do sistema antioxidante em lidar com a alta produção de ROS resultantes do metabolismo de xenobióticos ou inibição diante da presença de algum contaminante. Alguns autores também encontraram inconsistências entre respostas antioxidantes e estresse oxidativo (Box et al., 2007; Devier et al., 2005; Edge et al., 2012). Sob outra perspectiva, isso pode ser explicado pelas maiores concentrações de $\mathrm{Pb}, \mathrm{Fe}$, $\mathrm{Co}$ e $\mathrm{Zn}$ encontradas nos organismos de Santos. Diversos autores reportam o aumento na síntese de GSH quando da exposição dos bivalves a metais (e.g. $\mathrm{Zn}, \mathrm{Cu}$ ) como mecanismo de defesa (Franco et al., 2006; Sparks et al., 2018; Trevisan et al., 2014). Adicionalmente, o aumento da atividade enzimática de ChE pode estar associado a processos apoptóticos (Du et al., 2015; Zhang \& Greenberg, 2012), apontando para organismos com saúde muito prejudicada.

Por outro lado, as respostas metabólicas apresentadas pelos organismos de Bertioga podem indicar contaminação predominante por metais. Estes resultados são corroborados pelas análises de metais, que demonstraram que os organismos coletados em Bertioga foram os que apresentaram as maiores concentrações para a maioria dos elementos. Estudos recentes demonstraram que metais podem superproduzir ROS com a consequente depleção de grupos sulfidrila (-SH), LPO e danos em DNA (Wu et al., 2016). No presente caso, contudo, as defesas podem ser suficientes para minimizar alguns dos efeitos da contaminação, uma vez que os níveis de LPO são menores em relação aos organismos dos outros dois pontos e não foram observados danos em DNA. Sob outra perspectiva, levando em consideração o padrão de respostas dos outros mecanismos fisiológicos, é provável que os organismos tenham sofrido algum efeito decorrente do estresse oxidativo, vide a baixa integridade da membrana lisossômica. Wang \& Wang (2010) sugerem que fatores envolvidos em LPO não dependem significativamente das atividades das enzimas antioxidantes, ou seja, o nível de LPO nem sempre se relaciona ao conteúdo celular de ROS, podendo ser controlado por outros fatores. Além disso, efeitos neurotóxicos ficaram evidentes através da inibição de ChE, o que também pode estar relacionado à exposição a metais (Frasco et al., 2005).

O fato das ostras de Cananéia exibirem ativação da fase I do metabolismo e do sistema antioxidante e apresentarem peroxidação lipídica pode sugerir que estes organismos estão sujeitos a algum tipo de contaminação. Não obstante, a peroxidação lipídica pode refletir danos oxidativos associados a outros estressores ambientais, como sugerido por Edge et al. (2012), cujos organismos provenientes do estuário utilizado 
como referência de qualidade também apresentaram altos níveis de LPO. Em todo caso, quando comparadas as respostas obtidas na primavera de 2016 e no outono de 2017, observa-se que houve diminuição de DNA e aumento da atividade de ChE, podendo indicar recuperação do estado de saúde das ostras de Cananéia entre estas estações.

Através dos resultados do ensaio de NRRT realizado nas ostras coletadas durante a primavera de 2016 e o outono de 2017 é possível observar a baixa integridade da membrana lisossômica para Santos e Bertioga nas duas estações. Quando comparados em relação a BAC e EAC, estes resultados demonstram organismos severamente estressados. Isso pode ser indicativo de uma exposição crônica a fontes de contaminação, provavelmente presentes ao longo do ano. Ainda, os organismos de Santos tenderam a apresentar menores NRRT em ambas as estações, sugerindo saúde mais prejudicada.

Por outro lado, se utilizarmos os valores sugeridos por Ortega et al. (2018), os organismos coletados durante a primavera de 2016 em todos os pontos podem ser considerados estressados, mas compensando. Da mesma forma, as ostras de Cananéia e Bertioga coletadas durante o outono de 2017 também estariam estressadas, mas compensando; e as ostras de Santos seriam consideradas severamente estressadas.

Em estudo anterior com ostras coletadas nos mesmos pontos ao longo de um ano, Catharino et al. (2015) obtiveram respostas similares, sendo que os organismos dos Estuários de Santos e de Bertioga apresentaram redução de NRRT em relação a Cananéia. As ostras do Estuário de Santos foram consideradas pelos autores como as mais contaminadas, apresentando as maiores concentrações de diversos elementos analisados (Cd, Co, Fe, Hg, Pb, Se e $\mathrm{Zn})$. Estas altas concentrações foram atribuídas ao lançamento de efluentes industriais e domésticos e às operações de dragagem que ocorrem regularmente no Canal de Santos. Em Bertioga, houve altas concentrações de $\mathrm{As}, \mathrm{Cr}, \mathrm{Fe}$ e $\mathrm{Pb}$ nos tecidos dos organismos. Curiosamente, foram encontrados altos teores de As e Fe nas ostras da área de referência.

Estes resultados devem ser interpretados com cautela, uma vez que pode haver diferença nas respostas de biomarcadores entre diferentes populações dependendo de seu histórico de exposição à contaminação e de seu estado físiológico, podendo apresentar adaptações fisiológicas à contaminação ambiental (Beeby, 2001; Pereira et al., 2014). Ao comparar as respostas bioquímicas medidas em ostras nativas e transplantadas expostas à contaminação do SES, Maranho et al. (2012) observaram diferenças significativas entre os biomarcadores de exposição (EROD, DBF e GST), 
mas não entre biomarcadores de efeito, sugerindo que estes últimos são menos suscetíveis a flutuações. Da mesma forma, Fernández et al. (2010) não encontraram danos peroxidativos em mexilhões coletados em locais altamente poluídos, apesar dos organismos apresentarem níveis aumentados de enzimas antioxidantes. Estas evidências corroboram o observado neste estudo, em que não foi observada diferença entre os níveis de LPO e DNA nas diferentes estações do ano para Santos e Bertioga.

Considerando os resultados da PCA, é possível observar que o primeiro fator demonstrou de forma significativa a relação entre a maioria dos biomarcadores bioquímicos (GST inversamente), sendo que Cananéia e Santos no outono de 2017 estiveram associados a este fator (scores positivos). Por outro lado, este fator correlacionou também alguns metais entre si, sendo representativo para Santos na primavera de 2016 e Bertioga em ambas as estações do ano (scores negativos). A partir disso, é possível inferir que as ostras de Bertioga estão expostas a contaminação constante por metais. Ainda, as ostras de Cananéia e Santos no outono de 2017 apresentaram maior quantidade de alterações metabólicas, apontando para exposição a contaminantes ambientais.

O segundo fator demonstrou relação entre NRRT, Cd, As e $\mathrm{Cr}$, sendo representativo de Cananéia em ambas as estações do ano e Bertioga no outono de 2017 (scores negativos). Também, foram relacionados entre si os elementos $\mathrm{Hg}, \mathrm{Pb}, \mathrm{Co}$ e $\mathrm{Zn}$, estando associados a Santos em ambas as estações e Bertioga na primavera de 2016. Apesar deste fator também demonstrar a presença constante de contaminantes em Santos ao longo do ano, o fato de Bertioga e Santos terem se relacionado de formas diferentes aos eixos corrobora a hipótese de diferentes perfis de contaminação nestes locais. Também fica evidente que, apesar dos maiores NRRT, Cananéia apresenta altos teores de $\mathrm{Cd}$, As e Cr.

\subsection{Discussão geral}

\subsubsection{Mexilhões $P$. perna}

Considerando os resultados de bioacumulação de metais e de respostas biológicas (biomarcadores bioquímicos e fisiológico) obtidos para os mexilhões em todas as campanhas analisadas, é possível observar que a contaminação na Praia da Cocanha, na Ilhas das Palmas e na Ponta de Itaipu apresenta diferentes perfis e pode variar em função de diversos fatores. 
Os organismos coletados na Cocanha apresentaram elevados níveis de bioacumulação de metais, inclusive maiores do que nos outros dois pontos de coleta. Esses resultados podem estar relacionados à forte atividade turística sazonal, sobre a qual se baseia a economia da região (Pereira et al., 2009). O aumento populacional e a intensificação do tráfego de embarcações decorrentes destas atividades acarretam na introdução de maior volume de efluentes domésticos, os quais tem sido associados à contaminação por metais (Fjällborg et al., 2005; Hortellani et al., 2008; Kumar et al., 2015). Pereira et al. (2009) classificou o município de Caraguatatuba como de alto grau de impacto antropogênico, levando em consideração uma série de dados básicos e indicadores de sustentabilidade, dentre os quais urbanização, intensidade de pobreza, pesca, esgotamento sanitário e densidade demográfica. Além disso, as praias do município vem demonstrando moderada qualidade ambiental na última década (CETESB, 2017), sendo que os organismos coletados nos cultivos localizados na Cocanha também tem apresentado bioacumulação de contaminantes e alterações das respostas biológicas (Catharino et al., 2012; 2008; Pereira et al., 2012).

Na Baía de Santos, os organismos coletados na Ilha das Palmas e na Ponta de Itaipu apresentaram condições físiológicas bastante semelhantes. Entretanto, como houve diferença em algumas respostas bioquímicas, é possível inferir que os organismos de cada ponto estão sujeitos a um tipo de contaminação. O mesmo foi observado por Pereira et al. (2011), que atribuíram a saúde prejudicada dos organismos à exposição a fontes difusas de contaminação. Ambos os pontos sofrem influência das águas provenientes do interior dos Estuários de Santos (Palmas) e São Vicente (Itaipu), estando sujeitos à contaminação oriunda das indústrias, lixões irregulares, ocupações irregulares e disposição de esgotos sanitários in natura nestes corpos d'água (Abessa et al., 2005a; C. C. Martins et al., 2008; Oliva, 2003).

Além disso, o emissário submarino de Santos é uma das principais fontes de alteração e degradação da qualidade ambiental desta área (Abessa et al., 2005a; CETESB, 2007; Sousa et al., 2014; Subtil et al., 2012). Adicionalmente aos contaminantes clássicos, como metais, LABs (alquilbenzenos lineares), HPAs e PCBS, compostos de preocupação emergente como tintas anti-incrustantes, fármacos e drogas ilícitas também tem sido detectados na região (Godoi et al., 2003; Pereira et al., 2016; Pusceddu et al., 2018; Santos et al., 2018). Ressalta-se a inexistência de uma estação de tratamento de esgoto no município de Santos, sendo que os efluentes coletados passam apenas por uma estação de pré-condicionamento, onde são sujeitos a gradeamento, 
peneiramento e desinfecção por cloro e peróxido de hidrogênio (CETESB, 2007). Não obstante, Rachid (2002) avaliou a toxicidade dos efluentes antes e depois do précondicionamento e demonstrou que o efluente pré-condicionado era mais tóxico, provavelmente em decorrência do processo de cloração.

As operações de dragagem no Canal de Santos também contribuem para a mobilização de substâncias tóxicas do fundo para a coluna d'água. Torres et al. (2009) demonstraram a presença de metais e compostos orgânicos persistentes (i.e. HPAs, alifáticos e PCBs) nos sedimentos dragados.

Outro fator que se deve ponderar é o regime de ventos e correntes na região. $\mathrm{O}$ padrão horário de circulação das águas no interior da Baía de Santos influi diretamente sobre a dispersão da pluma de esgotos do emissário submarino no lado oeste (Itaipu) (Harari et al., 2000), assim como a pluma de dispersão do emissário submarino do Canto do Forte (no município vizinho de Praia Grande) pode ser direcionada para dentro da baía, dependendo das condições de correntes e ventos (São Paulo, 2010).

É importante lembrar que Itaipu está localizado dentro dos limites de uma Unidade de Conservação de Proteção Integral, o Parque Estadual Xixová-Japuí (PEXJ). Um dos principais objetivos deste tipo de unidades de conservação visa à preservação dos ecossistemas naturais de grande relevância ecológica e beleza cênica (Brasil, 2000). Segundo Oliva (2003), o PEXJ é responsável pela proteção da biodiversidade remanescente em uma região bastante atingida por impactos resultantes da ocupação urbana, industrialização e atividades portuárias. Entretanto, os resultados obtidos no presente estudo, em conjunto com evidências de estudos anteriores na mesma região, corroboram que esta unidade de conservação não tem cumprido totalmente seus objetivos de conservação (Araujo et al., 2013; Camargo, 2016; Moreira et al., 2017).

Ainda, observou-se diferença na contaminação entre as diferentes estações do ano estudadas. Isso pode ser explicado pelas características de cada período. A estação de primavera-verão (outubro-março) caracteriza-se pela ocorrência de chuvas intensas, com média pluviométrica de cerca de $350 \mathrm{~mm} / \mathrm{mês}$, enquanto o período de outonoinverno (abril-setembro) é mais seco, com média pluviométrica de cerca de 200 mm/mês (CETESB, 2017; Sant'anna Neto, 2005). Gusso-Choueri et al. (2015) demonstraram diferenças na bioacumulação de metais e nas respostas metabólicas de bagres (C. spixii) coletados em diferentes estações do ano, sendo que as maiores alterações ocorreram durante a estação chuvosa. Essas variações devem ser levadas em 
consideração em estudos de biomonitoramento, uma vez que podem interferir na interpretação dos efeitos da poluição sobre a biota (Monteiro et al., 2007).

\subsubsection{Ostras C. brasiliana}

Considerando os resultados de bioacumulação de metais e de respostas biológicas (biomarcadores bioquímicos e fisiológico) obtidos para as ostras em todas as campanhas analisadas, é possível observar que os Estuários de Cananéia, de Santos e de Bertioga sofrem diferentes pressões, sendo que os organismos que habitam estes locais respondem de maneira diferenciada.

Em Cananéia, as ostras apresentaram bioacumulação de As e Cd ao longo do tempo, sugerindo que estes elementos estão presentes no estuário, mas não necessariamente se associam a fontes pontuais de poluição. A região do Complexo Estuarino-Lagunar de Cananéia-Iguape-Peruíbe tem histórico de contaminação por metais devido às antigas atividades de mineração que ocorriam no Rio Ribeira de Iguape, as quais foram interrompidas na década de 1990 (Mahiques et al., 2009). Apesar disso, a contaminação por estes poluentes persiste até hoje, sendo registradas altas concentrações de metais nas águas, nos sedimentos e na biota, provenientes de fontes antropogênicas (Catharino et al., 2015; Guimarães \& Sígolo, 2008; GussoChoueri et al., 2015; Mahiques et al., 2009).

Adicionalmente, as ostras de Cananéia demonstraram alterações no metabolismo de xenobióticos na maioria das estações estudadas, com respostas antioxidantes e estresse oxidativo. Isso é corroborado pelo reportado por GussoChoueri et al. (2015), que detectaram metabólitos de metais e HPAs em bile de peixes demersais (C. spixii) associada a respostas antioxidantes, estresse oxidativo, neurotoxicidade e genotoxicidade. Os autores identificaram que efluentes urbanos da cidade de Cananéia e a drenagem fluvial do Rio Ribeira de Iguape foram identificados como as principais fontes de poluição desta região (Cruz et al., 2014; Gusso-Choueri et al., 2015). O fato das respostas aparecerem majoritariamente durante a primavera-verão pode estar associada tanto à flutuabilidade da densidade demográfica em função do turismo, que acarreta em maior volume de esgotos descartados, quanto à sazonalidade, com a qual variam os índices pluviométricos da região (CETESB, 2017; Gusso-Choueri et al., 2015).

Um ponto importante a ser considerado é que o estuário de Cananéia integra parte da Área de Proteção Ambiental Cananéia-Iguape-Peruíbe e é reconhecido pela 
UNESCO (United Nations Educational, Scientific and Cultural Organization) como Reserva da Biosfera da Mata Atlântica. Esta unidade de conservação visa conciliar a conservação da natureza ao desenvolvimento e manejo sustentado dos seus recursos. Entretanto, fica evidente que, mesmo que os contaminantes estejam presentes em níveis moderados, ele ainda são capazes de causar efeitos sobre a biota. Neste caso, o monitoramento da qualidade ambiental dentro dos limites das unidades de conservação seria mais efetivo se considerasse, além das análises químicas, as respostas biológicas da biota, fornecendo informações mais robustas para a administração destas áreas (Araujo et al., 2013; Gusso-Choueri et al., 2015; Moreira et al., 2017).

De maneira geral, é possível afirmar que as ostras coletadas em Santos, apresentaram pior condição fisiológica, pois exibiram a maior quantidade de alterações bioquímicas nas diferentes estações do ano. Isso não é novidade e só adiciona evidências sobre os graves impactos das atividades presentes na região sobre a vida aquática. Diversos estudos relatam a intensa contaminação por metais, HPAs e PCBs, provenientes principalmente das atividades portuárias e industriais desenvolvidas no Sistema Estuarino de Santos (SES) e da disposição de esgotos pelo emissário submarino e pelas ocupações irregulares no estuário (Abessa, 2002; Berbel et al., 2015; Boldrini \& Pereira, 1987; Buruaem et al., 2012; Cesar et al., 2007; Hortellani et al., 2008; LuizSilva et al., 2002; C. C. Martins et al., 2008; Sousa et al., 2014; Yogui et al., 2003).

Em relação às ostras coletadas em Bertioga, observa-se que nas campanhas de 2008/09 os organismos apresentaram boas condições fisiológicas e baixos níveis de bioacumulação de metais. Entretanto, o cenário muda em 2016/17, em que foram detectadas respostas das enzimas de biotransformação e antioxidantes e efeitos neurotóxicos associados a elevados níveis de diversos metais. Em Bertioga, a principal fonte de contaminação são os esgotos domésticos, os quais são descartados no ambiente aquático muitas vezes sem tratamento, uma vez que seu sistema de coleta atende apenas 27\% da população (CETESB, 2017; Morais et al., 2011; Zaroni, 2006). Essa introdução de substâncias com potencial tóxico no sistema aquático cria condições de degradação, comprometendo a qualidade ambiental no Estuário de Bertioga (Gonçalves et al., 2013). 


\section{Conclusões}

Os mexilhões coletados na Praia da Cocanha apresentaram elevados níveis de bioacumulação de metais, inclusive maiores do que nos outros dois pontos de coleta, o que pode estar relacionado ao turismo que ocorre na região.

$\mathrm{Na}$ Ilha das Palmas e na Ponta de Itaipu, os mexilhões apresentaram saúde prejudicada, sendo que os perfis de contaminação de cada ponto são diferentes. Na Ilha das Palmas, sob maior influência do Canal de Santos e do Porto de Santos, há contaminação por orgânicos (provavelmente por causa da disposição de esgotos no interior do estuário e na Baía de Santos) e por metais (em função das atividades industriais e portuárias no entorno), havendo ativação das respostas de biotransformação (fase I do metabolismo) e conjugação (fase II), além de indução do sistema antioxidante. Já na Ponta de Itaipu, ausência de ativação das respostas de biotransformação permitem inferir contaminação predominante por metais.

As ostras coletadas no Estuário de Santos exibiram piores condições fisiológicas dentre as ostras analisadas, uma vez que apresentaram maior quantidade de alterações bioquímicas nas diferentes estações do ano estudadas. Estes organismos estão sujeitos a contaminação por metais e possivelmente orgânicos, em função das descargas de efluentes industriais e domésticos, além das atividades portuárias da região.

Em Bertioga, as ostras coletadas nas campanhas de 2008/09 estavam em boas condições fisiológicas, sendo que os níveis de bioacumulação de metais eram baixos. Entretanto, nas campanhas de 2016/17 foi observada a piora das condições dos organismos deste local. Foi identificada a bioacumulação de diversos metais, além de ativação das respostas de biotransformação e antioxidantes e efeitos neurotóxicos. A principal fonte de contaminação nesta região são os esgotos domésticos. É preciso atentar para o fato de que a maioria dos estudos na região são feitos no Canal de Bertioga. Porém, essa tendência de aumento da degradação ambiental nas ostras coletadas no estuário do rio Itaguaré evidenciam a necessidade de monitoramento da contaminação também neste local, para que a degradação não se torne irreversível.

Em Cananéia, as ostras apresentaram bioacumulação de As e Cr, respostas das fases I e II do metabolismo e efeitos peroxidativos, apontando para possível exposição a fontes pontuais de contaminação por esgotos domésticos. Além disso, é possível afirmar que a sazonalidade das chuvas interfere nas características da contaminação, produzindo diferentes respostas entre períodos secos e períodos chuvosos. 
Os pontos escolhidos como referência de qualidade (i.e. Cocanha e Cananéia) demonstraram também estar sob influência de fontes pontuais de contaminação.

Em relação aos organismos utilizados no estudo, os mexilhões $P$. perna e as ostras C. brasiliana mostraram ser confiáveis como sentinelas da contaminação, cujas respostas biológicas fornecem boas informações sobre os impactos a que estão sujeitos. Porém, deve-se levar em consideração que a fisiologia destes organismos é diferente, refletindo em formas diferentes de responder à contaminação.

Os mexilhões demonstraram ser mais sensíveis a flutuações das respostas bioquímicas, sendo que se estiveram mais vulneráveis à contaminação em épocas coincidentes com fases de seu ciclo reprodutivo. Portanto, recomenda-se que este período seja evitado para coleta de organismos, uma vez que pode fornecer informações exacerbadas sobre as alterações metabólicas em função da contaminação ambiental.

A utilização de organismos residentes se mostrou um método viável e eficiente para avaliação da bioacumulação de metais. Entretanto, a comparação entre as respostas biológicas de cada população e sua interpretação devem ser feitas com cautela, uma vez que pode haver diferenças nas respostas de biomarcadores entre diferentes populações dependendo de seu histórico de exposição à contaminação, podendo apresentar adaptações fisiológicas à contaminação ambiental.

Finalmente, é proposta a inclusão das análises de biomarcadores nos programas de avaliação e monitoramento dos efeitos da contaminação em áreas marinhas protegidas, uma vez que a contaminação que atinge estas unidades de conservação muitas vezes se originam além de seus limites, dificultando seu manejo e mitigação. Neste sentido, a avaliação dos efeitos sobre a biota oferecem ferramentas para o gerenciamento mais efetivo destas unidades de conservação, visando o cumprimento de seus objetivos. 


\section{Referências bibliográficas}

Abdi, H. 2007. The Bonferonni and Šidák corrections for multiple comparisons, in: Salkind, N. (Ed.), Encyclopedia of Measurement and Statistics. Thousand Oaks, CA: Sage, pp. 1-9.

Abessa, D.M.S. 2002. Avaliação da qualidade dos sedimentos do Sistema Estuarino de Santos, SP, Brasil. São Paulo, SP: Universidade de São Paulo (USP).

Abessa, D.M.S.; Carr, R.S.; Rachid, B.R.F.; Sousa, E.C.P.M.; Hortellani, M.A.; Sarkis, J.E.S. $2005 a$. Influence of a Brazilian sewage outfall on the toxicity and contamination of adjacent sediments. Mar. Pollut. Bull. 50(8): 875-85.

Abessa, D.M.S.; Zaroni, L.P.; Sousa, E.C.P.M.; Gasparro, M.R.; Pereira, C.D.S.; Rachid, B.R.F.; Depledge, M.H.; King, R.S. 2005b. Physiological and cellular responses in two populations of the mussel Perna perna collected at different sites from the coast of São Paulo, Brazil. Brazilian Arch. Biol. Technol. 48(2): 217-25.

Adams, S.M. 2005. Assessing cause and effect of multiple stressors on marine systems. Mar. Pollut. Bull. 51: 649-657.

Aguirre-Martínez, G. V.; DelValls, T.Á.; Martín-Díaz, M.L. 2013. Identification of biomarkers responsive to chronic exposure to pharmaceuticals in target tissues of Carcinus maenas. Mar. Environ. Res. 87-88: 1-11.

Aidar, E.; Gaeta, S.A.; Gianesella-Galvão, S.M.F.; Kutner, M.B.B.; Teixeira, C. 1993. Ecossistema costeiro subtropical: nutrientes dissolvidos, fitoplâncton e cloroflla-a e suas relações com as condições oceanográficas na região de Ubatuba, SP. Publ. Espec. Inst. Ocean. 10(10): 9-43.

Al-Ghais, S.M.; Ali, B. 1999. Inhibition of glutathione S-transferase catalyzed xenobiotic detoxication by organotin compounds in tropical marine fish tissues. Bull. Environ. Contam. Toxicol. 62: 207-213.

Almeida, E.A.; Bainy, A.C.D.; Loureiro, A.P. de M.; Martinez, G.R.; Miyamoto, S.; Onuki, J.; Barbosa, L.F.; Garcia, C.C.M.; Prado, F.M.; Ronsein, G.E.; Sigolo, C.A.; Brochini, C.B.; Martins, A.M.G.; Medeiros, M.H.G. de; Di Mascio, P. 2007. Oxidative stress in Perna perna and other bivalves as indicators of environmental stress in the Brazilian marine environment: antioxidants, lipid peroxidation and DNA damage. Comp. Biochem. Physiol. A 146(4): 588-600.

Ambrozevicius, A.P.; Abessa, D.M.S. 2008. Acute toxicity of waters from the urban drainage channels of Santos (São Paulo, Brazil). Panam. J. Aquat. Sci. 3(2): 108-115.

Ameur, W. Ben; de Lapuente, J.; El Megdiche, Y.; Barhoumi, B.; Trabelsi, S.; Camps, L.; Serret, J.; Ramos-López, D.; Gonzalez-Linares, J.; Driss, M.R.; Borràs, M. 2012. Oxidative stress, genotoxicity and histopathology biomarker responses in mullet (Mugil cephalus) and sea bass (Dicentrarchus labrax) liver from Bizerte Lagoon (Tunisia). Mar. Pollut. Bull. 64(2): 241-251.

Araujo, G.S.; Moreira, L.B.; Morais, R.D.; Davanso, M.B.; Fonseca, T.G.; Cruz, A.C.F.; Abessa, D.M.S. 2013. Ecotoxicological assessment of sediments from an urban marine protected area (XixováJapuí State Park, SP, Brazil). Mar. Pollut. Bull. 75(1-2): 62-68.

Bainy, A.C.D.; Saito, E.; Carvalho, P.S.M.; Junqueira, V.B.C. 1996. Oxidative stress in gill, erythrocytes, liver and kidney of Nile tilapia (Oreochromis niloticus) from a polluted site. Aquat. Toxicol. 34(2): $151-162$.

Bebianno, M.J.; Lopes, B.; Guerra, L.M.; Hoarau, P.; Ferreira, A.M. 2007. Glutathione S-tranferases and cytochrome P450 activities in Mytilus galloprovincialis from the South coast of Portugal: effect of abiotic factors. Environ. Int. 33(4): 550-558.

Beeby, A. 2001. What do sentinels stand for? Environ. Pollut. 112(2): 285-298.

Berbel, G.B.B.; Favaro, D.I.T.; Braga, E.S. 2015. Impact of harbour, industry and sewage on the phosphorus geochemistry of a subtropical estuary in Brazil. Mar. Pollut. Bull. 93(1-2): 44-52.

Bernadochi, L.C.; Alves, J.L.; Marques, H.L. de A. 2016. Settlement of juveniles of pearl oyster (Pinctada imbricata) on artificial collectors in Caraguatatuba, Sao Paulo, Brazil. Aquac. Res. 47(2): 424-432.

Bocchetti, R.; Fattorini, D.; Pisanelli, B.; Macchia, S.; Oliviero, L.; Pilato, F.; Pellegrini, D.; Regoli, F. 2008. Contaminant accumulation and biomarker responses in caged mussels, Mytilus galloprovincialis, to evaluate bioavailability and toxicological effects of remobilized chemicals 
during dredging and disposal operations in harbour areas. Aquat. Toxicol. 89(4): 257-266.

Bocquené, G.; Roig, A.; Fournier, D. 1997. Cholinesterases from the common oyster (Crassostrea gigas). Evidence for the presence of a soluble acetylcholinesterase insensitive to organophosphate and carbamate inhibitors. FEBS Lett. 407(3): 261-266.

Boldrini, C.V.; Pereira, D.N. 1987. Metais pesados na baía de Santos e estuários de Santos e São Vicente: bioacumulação. Ambient. Rev. CETESB Tecnol. 1(3): 118-127.

Bonacci, S.; Iacocca, A.; Fossi, S.; Lancini, L.; Caruso, T.; Corsi, I.; Focardi, S. 2007. Biomonitoring aquatic environmental quality in a marine protected area: a biomarker approach. Ambio 36(4): 308315 .

Box, A.; Sureda, A.; Galgani, F.; Pons, A.; Deudero, S. 2007. Assessment of environmental pollution at Balearic Islands applying oxidative stress biomarkers in the mussel Mytilus galloprovincialis. Comp. Biochem. Physiol. C 146: 531-539.

Bradford, M.M. 1976. A rapid and sensitive method for the quantitation of microgram quantities of protein utilizing the principle of protein-dye binding. Anal. Biochem. 72(1-2): 248-254.

Braga, E.S.; Bonetti, C.V.D.H.; Burone, L.; Bonetti Filho, J. 2000. Eutrophication and bacterial pollution caused by industrial and domestic wastes at the Baixada Santista Estuarine System - Brazil. Mar. Pollut. Bull. 40(2): 165-73.

Brasil. 2013. Resolução RDC n ${ }^{0}$ 42, de 29 de agosto de 2013. Brasil: Dispões sobre o Regulamento Técnico MERCOSUL sobre limites máximos de contaminantes inorgânicos em alimentos.

Brasil. 2000. Lei ${ }^{\circ}$ 9.985, de julho de 2000. Brasil: Regulamenta o art. 225, §1o, incisos I, II, III e VII da Constituição Federal, institui o Sistema Nacional de Unidades de Conservação da Natureza e dá outras providências.

Brasil. 1965. Decreto $\mathrm{n}^{0}$ 55.871, de 26 de março de 1965. Brasil: Modifica o Decreto $\mathrm{n}^{0}$ 50.040, de 24 de janeiro de 1961, referente a normas reguladoras do emprêgo de aditivos para alimentos, alterado pelo Decreto n ${ }^{\circ}$ 691, de 13 de março de 1962.

Bresler, V.; Bissinger, V.; Abelson, A.; Dizer, H.; Sturm, A.; Kratke, R. 1999. Marine molluscs and fish as biomarkers of pollution stress in littoral regions of the Red Sea, Mediterranean Sea and North Sea. Helgol. Mar. Res. 53: 219-43.

Bryan, G.W.; Langston, W.J. 1992. Bioavailability, accumulation and effects of heavy metals in sediments with special reference to United Kingdom estuaries: a review. Environ. Pollut. 76(2): 89-131.

Buratti, S.; Franzellitti, S.; Poletti, R.; Ceredi, A.; Montanari, G.; Capuzzo, A.; Fabbri, E. 2013. Bioaccumulation of algal toxins and changes in physiological parameters in Mediterranean mussels from the North Adriatic Sea (Italy). Environ. Toxicol. 28(8): 451-470.

Buruaem, L.M.; Hortellani, M.A.; Sarkis, J.E.S.; Costa-Lotufo, L.V.; Abessa, D.M.S. 2012. Contamination of port zone sediments by metals from Large Marine Ecosystems of Brazil. Mar. Pollut. Bull. 64(3): 479-488.

Cajaraville, M.P.; Bebianno, M.J.; Blasco, J.; Porte, C.; Sarasquete, C.; Viarengo, A. 2000. The use of biomarkers to assess the impact of pollution in coastal environments of the Iberian Peninsula: a practical approach. Sci. Total Environ. 247(2-3): 295-311.

Calisi, A.; Lionetto, M.G.; Sanchez-Hernandez, J.C.; Schettino, T. 2011. Effect of heavy metal exposure on blood haemoglobin concentration and methemoglobin percentage in Lumbricus terrestris. Ecotoxicol. 20(4): 847-854.

Camargo, J.B.D.A. 2016. Assembleias macrobentônicas de uma área marinha protegida sob influência de impactos antropogênicos. São Vicente, SP: Universidade Estadual Paulista (UNESP).

Camargo, J.B.D.A.; Cruz, A.C.F.; Campos, B.G.; Araujo, G.S.; Fonseca, T.G.; Abessa, D.M.S. 2015. Use, development and improvements in the protocol of whole-sediment toxicity identification evaluation using benthic copepods. Mar. Pollut. Bull. 91(2): 511-517.

Capolupo, M.; Valbonesi, P.; Kiwan, A.; Buratti, S.; Franzellitti, S.; Fabbri, E. 2016. Use of an integrated biomarker-based strategy to evaluate physiological stress responses induced by environmental concentrations of caffeine in the Mediterranean mussel Mytilus galloprovincialis. Sci. Total 
Environ. 563-564: 538-548.

Carr, R.S.; Krause, P.; Montagna, P. 2008. Spatial and temporal patterns in toxicity around a municipalindustrial wastewater discharge in Corpus Christi Bay, Texas, in: Hofer, T.N. (Ed.), Marine Pollution: New Research. New York, NY: Nova Science Publishers, pp. 291-315.

Carraro, J.L. de F.; Rupp, G.S.; Mothes, B.; Lerner, C.; Würdig, N.L. 2012. Characterization of the fouling community of macroinvertebrates on the scallop Nodipecten nodosus (Mollusca, Pectinidae) farmed in Santa Catarina, Brazil. Ciecias Mar. 38(3): 577-588.

Castro-Filho, B.M.; Miranda, L.B. de. 1998. Physical oceanography of the western atlantic continental shelf located between $4^{\circ} \mathrm{N}$ and $34^{\circ} \mathrm{S}$, coastal segment (40W), in: Robinson, A.R., Brink, K.H. (Eds.), The Sea, Vol. 11: The Global Coastal Ocean. Cambridge: Harvard University Press, pp. 209-251.

Catharino, M.G.M.; Vasconcellos, M.B.A.; Kirschbaum, A.A.; Gasparro, M.R.; Minei, C.C.; Sousa, E.C.P.M.; Seo, D.; Moreira, E.G. 2012. Biomonitoring of coastal regions of São Paulo State, Brazil, using mussels Perna perna. J. Radioanal. Nucl. Chem. 291(1): 113-117.

Catharino, M.G.M.; Vasconcellos, M.B.A.; Kirschbaum, A.A.; Gasparro, M.R.; Sousa, E.C.P.M.; Minei, C.C.; Moreira, E.G. 2015. Passive biomonitoring study and effect biomarker in oysters Crassostrea brasiliana (Lamark, 1819: Mollusca, Bivalvia) in Santos and Cananéia Estuaries in São Paulo State, Brazil. J. Radioanal. Nucl. Chem. 303(3): 2297-2302.

Catharino, M.G.M.; Vasconcellos, M.B.A.; Sousa, E.C.P.M.; Moreira, E.G.; Pereira, C.D.S. 2008. Biomonitoring of $\mathrm{Hg}, \mathrm{Cd}, \mathrm{Pb}$ and other elements in coastal regions of São Paulo State, Brazil, using the transplanted mussel Perna perna (Linnaeus, 1758). J. Radioanal. Nucl. Chem. 278(3): 547-551.

Cesar, A.; Choueri, R.B.; Riba, I.; Morales-Caselles, C.; Pereira, C.D.S.; Santos, A.R.; Abessa, D.M.S.; DelValls, T.Á. 2007. Comparative sediment quality assessment in different littoral ecosystems from Spain (Gulf of Cadiz) and Brazil (Santos and São Vicente estuarine system). Environ. Int. 33: 429435.

CETESB (Companhia de Tecnologia e Saneamento Ambiental). 2017. Relatório de qualidade das praias no estado de São Paulo 2016. São Paulo, SP: CETESB.

CETESB (Companhia de Tecnologia e Saneamento Ambiental). 2009. Relatório de qualidade das águas litorâneas no estado de São Paulo 2008. São Paulo, SP.

CETESB (Companhia de Tecnologia e Saneamento Ambiental). 2008. Relatório de qualidade das águas litorâneas no estado de São Paulo 2007. São Paulo, SP.

CETESB (Companhia de Tecnologia e Saneamento Ambiental). 2007. Relatório de monitoramento de emissários submarinos. São Paulo, SP.

Chakraborty, S.; Ray, M.; Ray, S. 2010. Toxicity of sodium arsenite in the gill of an economically important mollusc of India. Fish Shellfish Immunol. 29(1): 136-148.

Chambers, J.E.; Boone, J.S.; Carr, R.L.; Chambers, H.W.; Straus, D.L. 2002. Biomarkers as predictors in health and ecological risk assessment. Hum. Ecol. Risk Assess. 8(1): 165-76.

Chamy, P.; Maldonado, W.T.P.V. 2002. Sustentabilidade social, econômica e ambiental de pequenos negocios: o caso da Cooperostra - Cananéia - SP, in: V Encontro Bienal Da Sociedade Brasileira de Economia Ecológica. Caxias do Sul, RS, pp. 1-24.

Chapman, P.M. 2007. Determining when contamination is pollution - Weight of evidence determinations for sediments and effluents. Environ. Int. 33(4): 492-501.

Cheung, V. V.; Wedderburn, R.J.; Depledge, M.H. 1998. Molluscan lysosomal responses as a diagnostic tool for the detection of a pollution gradient in Tolo Harbour, Hong Kong. Mar. Environ. Res. 46(1-5): 237-241.

Cho, S.-M.; Jeong, W.-G. 2005. Spawning impact on lysosomal stability of the Pacific Oyster, Crassostrea gigas. Aquaculture 244(1-4): 383-387.

Choueri, R.B.; Cesar, A.; Abessa, D.M.S.; Torres, R.J.; Morais, R.D.; Riba, I.; Pereira, C.D.S.; Nascimento, M.R.L.; Mozeto, A.A.; DelValls, T.Á. 2009. Development of site-specific sediment quality guidelines for North and South Atlantic littoral zones: comparison against national and international sediment quality benchmarks. J. Hazard. Mater. 170(1): 320-331. 
Corsi, I.; Mariottini, M.; Badesso, A.; Caruso, T.; Borghesi, N.; Bonacci, S.; Iacocca, A.; Focardi, S. 2005. Contamination and sub-lethal toxicological effects of persistent organic pollutants in the European eel (Anguilla anguilla) in the Orbetello lagoon (Tuscany, Italy). Hydrobiologia 550: 237249.

Cossu, C.; Doyotte, A.; Babut, M.; Exinger, A.; Vasseur, P. 2000. Antioxidant biomarkers in freshwater bivalves, Unio tumidus, in response to different contamination profiles of aquatic sediments. Ecotoxicol. Environ. Saf. 45(2): 106-121.

Costa, C.R.; Olivi, P.; Botta, C.M.R.; Espindola, E.L.G. 2008. A toxicidade em ambientes aquáticos: discussão e métodos de avaliação. Quim. Nova 31(7): 1820-30.

Cravo, A.; Pereira, C.D.S.; Gomes, T.; Cardoso, C.; Serafim, A.; Almeida, C.; Rocha, T.; Lopes, B.; Company, R.; Medeiros, A.; Norberto, R.; Pereira, R.; Araújo, O.; Bebianno, M.J. 2012. A multibiomarker approach in the clam Ruditapes decussatus to assess the impact of pollution in the Ria Formosa lagoon, South Coast of Portugal. Mar. Environ. Res. 75: 23-34.

Crespi, C.L.; Miller, V.P.; Penman, B.W. 1997. Microtiter plate assays for inhibition of human, drugmetabolizing cytochromes P450. Anal. Biochem. 248(1): 188-190.

Cruz, A.C.F.; Davanso, M.B.; Araujo, G.S.; Buruaem, L.M.; Santaella, S.T.; Morais, R.D.; Abessa, D.M.S. 2014. Cumulative influences of a small city and former mining activities on the sediment quality of a subtropical estuarine protected area. Environ. Monit. Assess. 186(11): 7035-7046.

Davenport, J.; Davenport, J.L. 2006. The impact of tourism and personal leisure transport on coastal environments: a review. Estuar. Coast. Shelf Sci. 67(1-2): 280-292.

Davies, I.M.; Gubbins, M.; Hylland, K.; Thain, J.; Maes, T.; Martínez-Gómez, C.; Giltrap, M.; Burgeot, T.; Wossiok, W.; Lang, T.; Vethaak, A.D. 2012. Technical annex: assessment criteria for biological effects measurements, in: Davies, I.M., Vethaak, A.D. (Eds.), Integrated Marine Environmental Monitoring of Chemicals and Their Effects. ICES Cooperative Research Report No. 315. Copenhagen, DNK: ICES, pp. 209-212.

Devier, M.-H.; Augagneur, S.; Budzinski, H.; Le Menach, K.; Mora, P.; Narbonne, J.-F.; Garrigues, P. 2005. One-year monitoring survey of organic compounds (PAHs, PCBs, TBT), heavy metals and biomarkers in blue mussels from the Arcachon Bay, France. J. Environ. Monit. 7(3): 224-240.

Díaz-Garduño, B.; Perales, J.A.; Biel-Maeso, M.; Pintado-Herrera, M.G.; Lara-Martin, P.A.; GarridoPérez, C.; Martín-Díaz, M.L. 2018. Biochemical responses of Solea senegalensis after continuous flow exposure to urban effluents. Sci. Total Environ. 615: 486-497.

Díaz-Jaramillo, M.; Rocha, A.M.; Gomes, V.; Bianchini, A.; Monserrat, J.M.; Sáez, K.; Barra, R. 2011. Multibiomarker approach at different organization levels in the estuarine Perinereis gualpensis (Polychaeta; Nereididae) under chronic and acute pollution conditions. Sci. Total Environ. 410411: $126-135$.

Domouhtsidou, G.P.; Dailianis, S.; Kaloyianni, M.; Dimitriadis, V.K. 2004. Lysosomal membrane stability and metallothionein content in Mytilus galloprovincialis (L.), as biomarkers. Combination with trace metal concentrations. Mar. Pollut. Bull. 48(5-6): 572-86.

Du, A.; Xie, J.; Guo, K.; Yang, L.; Wan, Y.; OuYang, Q.; Zhang, X.; Niu, X.; Lu, L.; Wu, J.; Zhang, X. 2015. A novel role for synaptic acetylcholinesterase as an apoptotic deoxyribonuclease. Cell Discov. 1: 1-17.

Edge, K.J.; Johnston, E.L.; Roach, A.C.; Ringwood, A.H. 2012. Indicators of environmental stress: cellular biomarkers and reproductive responses in the Sydney rock oyster (Saccostrea glomerata). Ecotoxicol. 21(5): 1415-1425.

Ellman, G.L.; Courtney, K.D.; Andres, Jr., V.; Featherstone, R.M. 1961. A new and rapid colorimetric determination of acetylcholinesterase activity. Biochem. Pharmacol. 7(2): 88-95.

Everaarts, J.M.; Sarkar, A. 1996. DNA damage as a biomarker of marine pollution: strand breaks in seastars (Asterias rubens) from the North Sea. Water Sci. Technol. 34(7-8): 157-162.

Fang, J.K.-H. 2007. Evaluation of lysosomal integrity in green-lipped mussel (Perna viridis) as a biomarker in environmental monitoring. City University of Hong Kong.

Farombi, E.O.; Adelowo, O.A.; Ajimoko, Y.R. 2007. Biomarkers of oxidative stress and heavy metal 
levels as indicators of environmental pollution in African cat fish (Clarias gariepinus) from Nigeria Ogun River. Int. J. Environ. Res. Public Health 4(2): 158-165.

Fenili, L.H. 2012. Qualidade do sedimento do canal de navegação do Porto de Santos (Santos, SP) após dragagem de aprofundamento: ensaios ecotoxicológicos com Tiburonella viscana e Nitokra sp. Universidade de São Paulo (USP).

Fernández, B.; Campillo, J.A.; Martínez-Gómez, C.; Benedicto, J. 2010. Antioxidant responses in gills of mussel (Mytilus galloprovincialis) as biomarkers of environmental stress along the Spanish Mediterranean coast. Aquat. Toxicol. 99(2): 186-197.

Fierz, M. de S.M.; Rosa, F.S. 1999. A paisagem x evolução do uso e ocupação do solo em Bertioga, litoral paulista. Rev. Dep. Geogr. 13: 259-287.

Fjällborg, B.; Ahlberg, G.; Nilsson, E.; Dave, G. 2005. Identification of metal toxicity in sewage sludge leachate. Environ. Int. 31(1): 25-31.

Francioni, E.; Wagener, A.L.R.; Scofield, A.L.; Depledge, M.H.; Cavalier, B. 2007. Evaluation of the mussel Perna perna as a biomonitor of polycyclic aromatic hydrocarbon (PAH) exposure and effects. Mar. Pollut. Bull. 54: 329-338.

Franco, J.L.; Trivella, D.B.B.; Trevisan, R.; Dinslaken, D.F.; Marques, M.R.F.; Bainy, A.C.D.; Dafre, A.L. 2006. Antioxidant status and stress proteins in the gills of the brown mussel Perna perna exposed to zinc. Chem. Biol. Interact. 160: 232-240.

Frasco, M.F.; Fournier, D.; Carvalho, F.; Guilhermino, L. 2005. Do metals inhibit acetylcholinesterase (AChE)? Implementation of assay conditions for the use of AChE activity as a biomarker of metal toxicity. Biomarkers 10(5): 360-375.

Freire, M.M.; Santos, V.G.; Ginuino, I.S.F.; Arias, A.R.L. 2008. Biomarcadores na avaliação da saúde ambiental dos ecossistemas aquáticos. Oecologia Bras. 12(3): 347-354.

Fukumoto, M.M.; Mahiques, M.M.; Tessler, M.G. 2004. Bottom faciology and sediment transport in Santos Bay, Southeastern Brazil. J. Coast. Res. SI 39: 1737-1740.

Gagné, F.; André, C.; Cejka, P.; Gagnon, C.; Blaise, C. 2007. Toxicological effects of primary-treated urban wastewaters, before and after ozone treatment, on freshwater mussels (Elliptio complanata). Comp. Biochem. Physiol. C 145(4): 542-552.

Gagné, F.; Blaise, C. 1993. Hepatic metallothionein level and mixed function oxidase activity in fingerling rainbow trout (Oncorhynchus mykiss) after acute exposure to pulp and paper mill effluents. Water Res. 27(11): 1669-1682.

Galloway, T.S.; Brown, R.J.; Browne, M.A.; Dissanayake, A.; Lowe, D.M.; Jones, M.B.; Depledge, M.H. 2004. A multibiomarker approach to environmental assessment. Environ. Sci. Technol. 38(6): $1723-1731$.

Galloway, T.S.; Millward, N.; Browne, M.A.; Depledge, M.H. 2002. Rapid assessment of organophosphorous/carbamate exposure in the bivalve mollusc Mytilus edulis using combined esterase activities as biomarkers. Aquat. Toxicol. 61(3-4): 169-180.

Galvão, M.S.N.; Pereira, O.M.; Machado, I.C.; Pimentel, C.M.M.; Henriques, M.B. 2009. Desempenho da criação da ostra de mangue Crassostrea sp. a partir da fase juvenil, em sistema suspenso, no estuário de Cananéia e no mar de Ubatuba (SP, Brasil). Bol. do Inst. Pesca 35(3): 401-411.

George, S.G. 1994. Enzymology and molecular biology of phase II xenobiotic-conjugating enzymes in fish, in: Malins, D.C., Ostrander, G.K. (Eds.), Aquatic Toxicology - Molecular, Biochemical and Cellular Perspectives. Boca Raton, FL: Lewis Publishers, pp. 37-85.

GESAMP (IMO/FAO/UNESCO-IOC/WMO/IAEA/UN/UNEP Joint Group of Experts on the Scientific Aspects of Marine Environmental Protection). 2001. Protecting the oceans from land-based activities - Land-based sources and activities afecting the quality and uses of the marine, coastal and associated freshwater environment, Reports and Studies.

Godoi, A.F.L.; Montone, R.C.; Santiago-Silva, M. 2003. Determination of butyltin compounds in surface sediments from the São Paulo State coast (Brazil) by gas chromatography-pulsed flame photometric detection. J. Chromatogr. A 985(1-2): 205-210.

Goldberg, E.D. 1975. The mussel watch - a first step in global marine monitoring. Mar. Pollut. Bull. 
6(7): 111.

Gonçalves, C.; Figueira, R.C.L.; Sartoretto, J.R.; Salaroli, A.B.; Ribeiro, A.P.; Ferreira, P.A.L.; Mahiques, M.M. 2013. Reconstruction of historical trends in potentially toxic elements from sediment cores collected in Bertioga Channel, southeastern Brazil. Brazilian J. Oceanogr. 61(2): $149-160$.

Gorbi, S.; Bocchetti, R.; Binelli, A.; Bacchiocchi, S.; Orletti, R.; Nanetti, L.; Raffaelli, F.; Vignini, A.; Accoroni, S.; Totti, C.; Regoli, F. 2012. Biological effects of palytoxin-like compounds from Ostreopsis cf. ovata: A multibiomarkers approach with mussels Mytilus galloprovincialis. Chemosphere 89(5): 623-632.

Guidi, P.; Frenzilli, G.; Benedetti, M.; Bernardeschi, M.; Falleni, A.; Fattorini, D.; Regoli, F.; Scarcelli, V.; Nigro, M. 2010. Antioxidant, genotoxic and lysosomal biomarkers in the freshwater bivalve (Unio pictorum) transplanted in a metal polluted river basin. Aquat. Toxicol. 100(1): 75-83.

Guilhermino, L.; Lopes, M.C.; Carvalho, A.P.; Soares, A.M.V.M. 1996. Inhibition of acetylcholinesterase activity as effect criterion in acute tests with juvenile Daphnia magna. Chemosphere 32(4): 727738.

Guimarães, V.; Sígolo, J.B. 2008. Associação de resíduos da metalurgia com sedimentos em suspensão Rio Ribeira de Iguape. Rev. Geol. USP 8(2): 1-10.

Gusso-Choueri, P.K.; Choueri, R.B.; Araujo, G.S.; Cruz, A.C.F.; Stremel, T.; Campos, S.; Abessa, D.M.S.; Ribeiro, C.A.O. 2015. Assessing pollution in marine protected areas: the role of a multibiomarker and multi-organ approach. Environ. Sci. Pollut. Res. 22(22): 18047-18065.

Hagger, J.A.; Galloway, T.S.; Copplestone, D. 2011. The use of biomarkers as simple, rapid costeffective techniques to aid in an integrated approach to environmental management and risk assessment with particular emphasis on radionuclides, in: Shimmield, G. (Ed.), Treatise on Estuarine and Coastal Science - Vol. 4: Geochemistry of Estuaries and Coasts. Elsevier Inc., pp. 339-354.

Halpern, B.S.; Walbridge, S.; Selkoe, K.A.; Kappel, C. V.; Micheli, F.; D’Agrosa, C.; Bruno, J.F.; Casey, K.S.; Ebert, C.; Fox, H.E.; Fujita, R.; Heinemann, D.; Lenihan, H.S.; Madin, E.M.P.; Perry, M.T.; Selig, E.R.; Spalding, M.D.; Steneck, R.S.; Watson, R. 2008. A global map of human impact on marine ecosystems. Science 319(5865): 948-952.

Handy, R.D.; Galloway, T.S.; Depledge, M.H. 2003. A proposal for the use of biomarkers for the assessment of chronic pollution and in regulatory toxicology. Ecotoxicol. 12: 331-43.

Hanson, N.; Larsson, A. 2010. Biomarker analyses in caged and wild fish suggest exposure to pollutants in an urban area with a landfill. Environ. Toxicol. 26(3): 315-324.

Harari, J.; Camargo, R. de; Cacciari, P.L. 2000. Resultados da modelagem numérica hidrodinâmica em simulações tridimensionais das correntes de maré na Baixada Santista. Rev. Bras. Recur. Hídricos 5(2): 71-87.

Hégaret, H.; Silva, P.M.; Wikfors, G.H.; Haberkorn, H.; Shumway, S.E.; Soudant, P. 2011. In vitro interactions between several species of harmful algae and haemocytes of bivalve molluscs. Cell Biol. Toxicol. 27(4): 249-266.

Henriques, M.B.; Casarini, L.M. 2009. Avaliação do crescimento do mexilhão Perna perna e da espécie invasora Isognomon bicolor em banco natural da Ilha das Palmas, Baía de Santos, estado de São Paulo, Brasil. Bol. do Inst. Pesca 35(4): 577-586.

Henriques, M.B.; Marques, H.L. de A.; Pereira, O.M.; Bastos, G.C.C. 2004. Aspectos da estrutura populacional do mexilhão Perna perna relacionados à extração em bancos naturais da Baía de Santos, estado de São Paulo, Brasil. Bol. do Inst. Pesca 30(2): 117-126.

Hortellani, M.A.; Sarkis, J.E.S.; Abessa, D.M.S.; Sousa, E.C.P.M. 2008. Avaliação da contaminação por elementos metálicos dos sedimentos do estuário Santos-São Vicente. Quim. Nova 31(1): 10-19.

Huggett, R.J. 1992. Biomarkers: biochemical, physiological, and histological markers of anthropogenic stress. Boca Raton, FL: Lewis Publishers.

Hwang, H.-M.; Wade, T.L.; Sericano, J.L. 2002. Relationship between lysosomal membrane destabilization and chemical body burden in eastern oysters (Crassostrea virginica) from Galveston 
Bay, Texas, USA. Environ. Toxicol. Chem. 21(6): 1268-1271.

IMW (International Mussel Watch Committee). 1995. International Mussel Watch Project: Initial Implementation Phase, Final Report. Silver Spring, MD.

Jesus, T.B.; Carvalho, C.E.V. 2008. Utilização de biomarcadores em peixes como ferramenta para avaliação de contaminação ambiental por mercúrio (Hg). Oecologia Bras. 12(4): 680-93.

Kovačević, T.B.; Borković, S.S.; Pavlović, S.Z.; Despotović, S.G.; Saičić, Z.S. 2008. Glutathione as a suitable biomarker in hepatopancreas, gills and muscle of three freshwater crayfish species. Arch. Biol. Sci. 60(1): 59-66.

Kumar, V.; Sinha, A.K.; Rodrigues, P.P.; Mubiana, V.K.; Blust, R.; De Boeck, G. 2015. Linking environmental heavy metal concentrations and salinity gradients with metal accumulation and their effects: A case study in 3 mussel species of Vitória estuary and Espírito Santo bay, Southeast Brazil. Sci. Total Environ. 523: 1-15.

Lafontaine, Y. de; Gagné, F.; Blaise, C.; Costan, G.; Gagnon, P.; Chan, H.M. 2000. Biomarkers in zebra mussels (Dreissena polymorpha) for the assessment and monitoring of water quality of the St. Lawrence River (Canada). Aquat. Toxicol. 50(1-2): 51-71.

Lamparelli, M.C.; Bevilacqua, J.E.; Costa, M.P.; Prósperi, V.A.; Araújo, R.P.A.; Pompéia, S.; Eysink, G.G.J. 2001. Sistema Estuarino de Santos e São Vicente. Santos, SP: CETESB/PROCOP.

Lehtonen, K.K.; Kankaanpää, H.; Leiniö, S.; Sipiä, V.O.; Pflugmacher, S.; Sandberg-Kilpi, E. 2003. Accumulation of nodularin-like compounds from the cyanobacterium Nodularia spumigena and changes in acetylcholinesterase activity in the clam Macoma balthica during short-term laboratory exposure. Aquat. Toxicol. 64(4): 461-476.

Levine, S.L.; Czosnyka, H.; Oris, J.T. 1997. Effect of the fungicide clotrimazole on the bioconcentration of benzo[a]pyrene in Gizzard shad (Dorosoma cepedianum): In vivo and in vitro inhibition of cytochrome P4501A activity. Environ. Toxicol. Chem. 16(2): 306-311.

Lionetto, M.G.; Caricato, R.; Calisi, A.; Giordano, M.E.; Schettino, T. 2013. Acetylcholinesterase as a biomarker in environmental and occupational medicine: new insights and future perspectives. Biomed Res. Int. 2013(321213): 1-8.

Lionetto, M.G.; Caricato, R.; Giordano, M.E.; Pascariello, M.F.; Marinosci, L.; Schettino, T. 2003. Integrated use of biomarkers (acetylcholinesterase and antioxidant enzymes activities) in Mytilus galloprovincialis and Mullus barbatus in an Italian coastal marine area. Mar. Pollut. Bull. 46(3): 324-330.

Lowe, D.M.; Soverchia, C.; Moore, M.N. 1995. Lysosomal membrane responses in the blood and digestive cells of mussels experimentally exposed to fluoranthene. Aquat. Toxicol. 33(2): 105-112.

Lüchmann, K.H.; Clark, M.S.; Bainy, A.C.D.; Gilbert, J.A.; Craft, J.A.; Chipman, J.K.; Thorne, M.A.S.; Mattos, J.J.; Siebert, M.N.; Schroeder, D.C. 2015. Key metabolic pathways involved in xenobiotic biotransformation and stress responses revealed by transcriptomics of the mangrove oyster Crassostrea brasiliana. Aquat. Toxicol. 166: 10-20.

Luiz-Silva, W.; Matos, R.H.R.; Kristosch, G.C. 2002. Geoquímica e índice de geoacumulação de mercúrio em sedimentos de superfície do estuário de Santos - Cubatão (SP). Quim. Nova 25(5): $753-756$.

Luoma, S.N.; Rainbow, P.S. 2005. Why is metal bioaccumulation so variable? Biodynamics as a unifying concept. Environ. Sci. Technol. 39(7): 1921-1931.

Mahiques, M.M.; Burone, L.; Figueira, R.C.L.; Lavenére-Wanderley, A.A. de O.; Capellari, B.; Rogacheski, C.E.; Barroso, C.P.; Santos, L.A.S.; Cordero, L.M.; Cussioli, M.C. 2009. Anthropogenic influences in a lagoonal environment: a multiproxy approach at the Valo Grande mouth, Cananéia-Iguape system (SE Brazil). Brazilian J. Oceanogr. 57(4): 325-337.

Manfrin, C.; De Moro, G.; Torboli, V.; Venier, P.; Pallavicini, A.; Gerdol, M. 2012. Physiological and molecular responses of bivalves to toxic dinoflagellates. Idaho State J. 184-199.

Maranho, L.A. 2014. Evaluación del riesgo ambiental de sedimentos marinos afectados por la contaminación de productos farmacéuticos: estudios en laboratorio e in situ. Universidad de Cádiz.

Maranho, L.A.; Pereira, C.D.S.; Choueri, R.B.; Cesar, A.; Gusso-Choueri, P.K.; Torres, R.J.; Abessa, 
D.M.S.; Morais, R.D.; Mozeto, A.A.; DelValls, T.Á.; Martín-Díaz, M.L. 2012. The application of biochemical responses to assess environmental quality of tropical estuaries: field surveys. $J$. Environ. Monit. 14(10): 2608-2615.

Mardia, K.V.; Kent, S.J.; Bibby, J.M. 1979. Multivariate Analysis. London, UK: Academic Press.

Martín-Díaz, M.L.; Blasco, J.; Sales, D.; DelValls, T.Á. 2008. Field validation of a battery of biomarkers to assess sediment quality in Spanish ports. Environ. Pollut. 151(3): 631-640.

Martín-Díaz, M.L.; Gagné, F.; Blaise, C. 2009. The use of biochemical responses to assess ecotoxicological effects of Pharmaceutical and Personal Care Products (PPCPs) after injection in the mussel Elliptio complanata. Environ. Toxicol. Pharmacol. 28(2): 237-242.

Martínez-Gómez, C.; Benedicto, J.; Campillo, J.A.; Moore, M.N. 2008. Application and evaluation of the neutral red retention (NRR) assay for lysosomal stability in mussel populations along the Iberian Mediterranean coast. J. Environ. Monit. 10(4): 490-9.

Martínez-Gómez, C.; Bignell, J.; Lowe, D. 2015. Lysosomal membrane stability in mussels, in: Keizer, P.D. (Ed.), ICES Techniques in Marine Environmental Sciences No. 56. Copenhagen, DNK: ICES, p. 41.

Martínez-Gómez, C.; Vethaak, A.D.; Hylland, K.; Burgeot, T.; Köhler, A.; Lyons, B.P.; Thain, J.; Gubbins, M.J.; Davies, I.M. 2010. A guide to toxicity assessment and monitoring effects at lower levels of biological organization following marine oil spills in European waters. ICES J. Mar. Sci. 67(6): 1105-1118.

Martins, C.C.; Gomes, F.B.A.; Ferreira, J.A.; Montone, R.C. 2008. Marcadores orgânicos de contaminação por esgotos sanitários em sedimentos superficiais da Baía de Santos, São Paulo. Quim. Nova 31(5): 1008-1014.

Martins, S.E.; Rossi, L.; Sampaio, P. de S.P.; Magenta, M.A.G. 2008. Caracterização florística de comunidades vegetais de restinga em Bertioga, SP, Brasil. Acta Bot. Brasilica 22(1): 249-274.

McCulloch, A.W.; Boyd, R.K.; Freitas, A.S.W.; Foxall, R.A.; Jamieson, W.D.; Laycock, M. V.; Quilliam, M.A.; Wright, J.L.C.; Boyko, V.J.; McLaren, J.W.; Miedema, M.R.; Pocklington, R.; Arsenault, E.; Richard, D.J.A. 1989. Zinc from oyster tissues as causative factor in mouse deaths in official bioassay for paralytic shellfish poison. J. Assoc. Off. Anal. Chem. 72(2): 384-386.

McFarland, V.A.; Inouye, L.S.; Lutz, C.H.; Jarvis, A.S.; Clarke, J.U.; McCant, D.D. 1999. Biomarkers of oxidative stress and genotoxicity in livers of field-collected brown bullhead, Ameiurus nebulosus. Arch. Environ. Contam. Toxicol. 37(2): 236-241.

McHugh, M.L. 2011. Multiple comparison analysis testing in ANOVA. Biochem. Medica 21(2): $203-9$.

Mendonça, J.T. 2007. Gestão dos recursos pesqueiros do Complexo Estuarino-Lagunar de CananéiaIguape-Ilha Comprida, Litoral Sul de São Paulo, Brasil. São Carlos, SP: Universidade Federal de São Carlos (UFSCar).

Monari, M.; Foschi, J.; Cortesi, P.; Rosmini, R.; Cattani, O.; Serrazanetti, G.P. 2008. Chloramphenicol influence on antioxidant enzymes with preliminary approach on microsomal CYP1A immunopositive-protein in Chamelea gallina. Chemosphere 73(3): 272-280.

Monteiro, M.; Quintaneiro, C.; Nogueira, A.J.A.; Morgado, F.; Soares, A.M.V.M.; Guilhermino, L. 2007. Impact of chemical exposure on the fish Pomatoschistus microps Krøyer (1838) in estuaries of the Portuguese Northwest coast. Chemosphere 66(3): 514-522.

Moore, M.N. 1985. Cellular responses to pollutants. Mar. Pollut. Bull. 16(4): 134-139.

Morais, A.V.; Bretas, E. dos S.; Pereira, C.D.S.; Cortez, F.S.; Cesar, A.; Santos, A.R. 2011. Avaliação da qualidade ambiental do rio Itaguaré, Bertioga-SP, com base em testes de toxicidade e indicadores microbiológicos de balneabilidade. O Mundo da Saúde 35(1): 55-63.

Morales-Caselles, C.; Lewis, C.; Riba, I.; DelValls, T.Á.; Galloway, T.S. 2009. A multibiomarker approach using the polychaete Arenicola marina to assess oil-contaminated sediments. Environ. Sci. Pollut. Res. 16(6): 618-629.

Moreira, L.B.; Vicente, T.M.; Taniguchi, S.; Hortellani, M.A.; Sarkis, J.E.S.; Bícego, M.C.; Abessa, D.M.S. 2017. Assessing legacy contaminants in sediments from marine protected areas of central coast of São Paulo (Brazil). Brazilian J. Oceanogr. 65(4): 549-563. 
Narchi, W.; Galvão-Bueno, M.S. 1997. Anatomia funcional de Perna perna (Linné) (Bivalvia, Mytilidae). Rev. Bras. Zool. 14(1): 135-168.

Neves, R.A.F.; Valentin, J.L. 2011. Revisão bibliográfica sobre a macrofauna bentônica de fundos nãoconsolidados, em áreas costeiras prioritárias para conservação no Brasil. Arq. Ciên. Mar 44(3): 5980 .

Nogueira, L.; Garcia, D.; Trevisan, R.; Sanches, A.L.M.; Acosta, D.S.; Dafre, A.L.; Oliveira, T.Y.K.; Almeida, E.A. 2015. Biochemical responses in mussels Perna perna exposed to diesel B5. Chemosphere 134: 210-216.

Nunes, B.; Gaio, A.R.; Carvalho, F.; Guilhermino, L. 2008. Behaviour and biomarkers of oxidative stress in Gambusia holbrooki after acute exposure to widely used pharmaceuticals and a detergent. Ecotoxicol. Environ. Saf. 71(2): 341-354.

Oliva, A. 2003. Programa de manejo fronteiras para o Parque Estadual Xixová-Japuí - SP. Piracicaba, SP: Universidade de São Paulo (USP).

Oliveira, H.H.P.; Liebel, S.; Rossi, S.C.; Azevedo, A.C.B.; Barrera, E.A.L.; Garcia, J.R.E.; Grötzner, S.R.; Neto, F.F.; Randi, M.A.F.; Ribeiro, C.A.O. 2015. Mixtures of benzo(a)pyrene, dichlorodiphenyltrichloroethane and tributyltin are more toxic to neotropical fish Rhamdia quelen than isolated exposures. Ecotoxicol. Environ. Saf. 122: 106-115.

Ortega, A.S.B.; Maranho, L.A.; Nobre, C.R.; Moreno, B.B.; Guimarães, R.S.; Lebre, D.T.; Abessa, D.M.S.; Ribeiro, D.A.; Pereira, C.D.S. 2018. Detoxification, oxidative stress, and cytogenotoxicity of crack cocaine in the brown mussel Perna perna. Environ. Sci. Pollut. Res. 1-10.

Páez-Osuna, F.; Frías-Espericueta, M.G.; Osuna-López, J.I. 1995. Trace metal concentrations in relation to season and gonadal maturation in the oyster Crassostrea iridescens. Mar. Environ. Res. 40(1): 19-31.

Payne, J.F.; Mathieu, A.; Melvin, W.; Fancey, L.L. 1996. Acetylcholinesterase, an old biomarker with a new future? Field trials in association with two urban rivers and a paper mill in Newfoundland. Mar. Pollut. Bull. 32(2): 225-231.

Pereira, C.D.S. 2008. Biomarcadores de exposição, efeito e bioacumulação de xenobióticos em mexilhões Perna perna (Linnaeus , 1758) transplantados ao longo do litoral de São Paulo. São Paulo, SP: Universidade de São Paulo (USP).

Pereira, C.D.S.; Abessa, D.M.S.; Bainy, A.C.D.; Zaroni, L.P.; Gasparro, M.R.; Bícego, M.C.; Taniguchi, S.; Furley, T.H.; Sousa, E.C.P.M. 2007. Integrated assessment of multilevel biomarker responses and chemical analysis in mussels from São Sebastião, São Paulo, Brazil. Environ. Toxicol. Chem. 26(3): 462-469.

Pereira, C.D.S.; Abessa, D.M.S.; Choueri, R.B.; Almagro-Pastor, V.; Cesar, A.; Maranho, L.A.; MartínDíaz, M.L.; Torres, R.J.; Gusso-Choueri, P.K.; Almeida, J.E.; Cortez, F.S.; Mozeto, A.A.; Silbiger, H.L.N.; Sousa, E.C.P.M.; DelValls, T.Á.; Bainy, A.C.D. 2014. Ecological relevance of sentinels' biomarker responses: a multi-level approach. Mar. Environ. Res. 96: 118-126.

Pereira, C.D.S.; Maranho, L.A.; Cortez, F.S.; Pusceddu, F.H.; Santos, A.R.; Ribeiro, D.A.; Cesar, A.; Guimarães, L.L. 2016. Occurrence of pharmaceuticals and cocaine in a Brazilian coastal zone. Sci. Total Environ. 548-549: 148-154.

Pereira, C.D.S.; Martín-Díaz, M.L.; Catharino, M.G.M.; Cesar, A.; Choueri, R.B.; Taniguchi, S.; Abessa, D.M.S.; Bícego, M.C.; Vasconcellos, M.B.A.; Bainy, A.C.D.; Sousa, E.C.P.M.; DelValls, T.Á. 2012. Chronic contamination assessment integrating biomarkers' responses in transplanted mussels — a seasonal monitoring. Environ. Toxicol. 27(5): 257-267.

Pereira, C.D.S.; Martín-Díaz, M.L.; Zanette, J.; Cesar, A.; Choueri, R.B.; Abessa, D.M.S.; Catharino, M.G.M.; Vasconcellos, M.B.A.; Bainy, A.C.D.; Sousa, E.C.P.M.; DelValls, T.Á. 2011. Integrated biomarker responses as environmental status descriptors of a coastal zone (São Paulo, Brazil). Ecotoxicol. Environ. Saf. 74(5): 1257-1264.

Pereira, F.R.S.; Kampel, M.; Souto, R.D.; Polette, M. 2009. Avaliação do impacto antropogênico no litoral norte de São Paulo utilizando técnicas de geoprocessamento, in: XIV Simpósio Brasileiro de Sensoriamento Remoto. Natal, RN: INPE, pp. 4223-4230.

Pereira, O.M.; Henriques, M.B.; Zenebon, O.; Sakuma, A.; Kira, C.S. 2002. Determinação dos teores de 
$\mathrm{Hg}, \mathrm{Pb}, \mathrm{Cd}, \mathrm{Cu}$ e $\mathrm{Zn}$ em moluscos (Crassostrea brasiliana, Perna perna e Mytella falcata). Rev. Inst. Adolfo Lutz 61(1): 19-25.

Pereira, O.M.; Machado, I.C.; Henriques, M.B.; Galvão, M.S.N.; Yamanaka, N. 2001a. Avaliação do estoque da ostra Crassostrea brasiliana em rios e gamboas da região estuarino-lagunar de Cananéia (São Paulo, Brasil). Bol. do Inst. Pesca 27(1): 85-95.

Pereira, O.M.; Machado, I.C.; Henriques, M.B.; Yamanaka, N. 2001b. Crescimento da ostra Crassostrea brasiliana semeada sobre tabuleiro em diferentes densidades na região estuarina-lagunar de Cananéia-SP $\left(25^{\circ} \mathrm{S}, 48^{\circ} \mathrm{W}\right)$. Bol. do Inst. Pesca 27(2): 163-174.

Pusceddu, F.H.; Choueri, R.B.; Pereira, C.D.S.; Cortez, F.S.; Santos, D.R.A.; Moreno, B.B.; Santos, A.R.; Rogero, J.R.; Cesar, A. 2018. Environmental risk assessment of triclosan and ibuprofen in marine sediments using individual and sub-individual endpoints. Environ. Pollut. 232: 274-283.

Rachid, B.R.F. 2002. Avaliação ecotoxicológica dos efluentes domésticos lançados pelos sistemas de disposição oceânica da Baixada Santista, SP. São Paulo, SP: Universidade de São Paulo (USP).

Regoli, F.; Giuliani, M.E. 2014. Oxidative pathways of chemical toxicity and oxidative stress biomarkers in marine organisms. Mar. Environ. Res. 93: 106-117.

Ricciardi, F.; Binelli, A.; Provini, A. 2006. Use of two biomarkers (CYP450 and acetylcholinesterase) in zebra mussel for the biomonitoring of Lake Maggiore (northern Italy). Ecotoxicol. Environ. Saf. 63(3): 406-412.

Rios, E. 1984. Seashells of Brazil, 2ª . ed. Rio Grande, RS: Fundação Universidade do Rio Grande (FURG).

Roméo, M.; Hoarau, P.; Garello, G.; Gnassia-Barelli, M.; Girard, J.P. 2003. Mussel transplantation and biomarkers as useful tools for assessing water quality in the NW Mediterranean. Environ. Pollut. 122(3): 369-378.

Ruppert, E.E.; Barnes, R.D. 1996. Zoologia dos Invertebrados, 6a . ed. São Paulo, SP: Ed. Roca.

Sant'anna Neto, J.L. 2005. Decálogo da climatologia do Sudeste brasileiro. Rev. Bras. Climatol. 1: 4360.

Santos, D.M.; Buruaem, L.; Gonçalves, R.M.; Williams, M.; Abessa, D.M.S.; Kookana, R.; Marchi, M.R.R. 2018. Multiresidue determination and predicted risk assessment of contaminants of emerging concern in marine sediments from the vicinities of submarine sewage outfalls. Mar. Pollut. Bull. 129(1): 299-307.

São Paulo (Estado). 2012. Complexo Estuarino Cananéia-Iguape. São Paulo, SP: SMA/CPLEA.

São Paulo (Estado). 2010. Plano de Manejo do Parque Estadual Xixová-Japuí. São Paulo, SP: Fundação Florestal.

Sardi, A.E.; Renaud, P.E.; Lana, P.C.; Camus, L. 2016. Baseline levels of oxidative stress biomarkers in species from a subtropical estuarine system (Paranaguá Bay, southern Brazil). Mar. Pollut. Bull. 113(1-2): 496-508.

Sedlak, J.; Lindsay, R.H. 1968. Estimation of total, protein-bound, and nonprotein sulfhydryl groups in tissue with Ellman's reagent. Anal. Biochem. 25(1): 192-205.

Seluchi, M.E.; Chou, S.C.; Gramani, M. 2011. A case study of a winter heavy rainfall event over the Serra do Mar in Brazil. Geofísica Int. 50(1): 41-56.

Seo, D.; Vasconcellos, M.B.A.; Catharino, M.G.M.; Moreira, E.G.; Sousa, E.C.P.M.; Saiki, M. 2013. Vanadium determination in Perna perna mussels (Linnaeus, 1758: Mollusca, Bivalvia) by instrumental neutron activation analysis using the passive biomonitoring in the Santos coast, Brazil. J. Radioanal. Nucl. Chem. 296(1): 459-463.

Siebert, M.N.; Mattos, J.J.; Piazza, C.E.; Lima, D. de; Gomes, C.H.A.M.; Melo, C.M.R.; Bainy, A.C.D. 2017. Characterization of ethoxyresorufin O-deethylase activity (EROD) in oyster Crassostrea brasiliana. Comp. Biochem. Physiol. B 203: 115-121.

Silva, C.A.R.; Rainbow, P.S.; Smith, B.D.; Santos, Z.L. 2001. Biomonitoring of trace metal contamination in the Potengi estuary, Natal (Brazil), using the oyster Crassostrea rhizophorae, a local food source. Water Res. 35(17): 4072-4078. 
SMA (Secretaria do Meio Ambiente). 1997. Congresso Brasileiro de Unidades de Conservação, in: Coletânea de Trabalhos. Curitiba, PR.

Smith, B.A.; Greenberg, B.; Stephenson, G.L. 2012. Bioavailability of copper and zinc in mining soils. Arch. Environ. Contam. Toxicol. 62(1): 1-12.

Solé, M.; Kopecka-Pilarczyk, J.; Blasco, J. 2009. Pollution biomarkers in two estuarine invertebrates, Nereis diversicolor and Scrobicularia plana, from a Marsh ecosystem in SW Spain. Environ. Int. 35(3): 523-531.

Song, L.; Li, X.; Clarke, S.; Wang, T.; Bott, K. 2007. The application of neutral red retention assay to evaluate the differences in stress responses to sexual maturation and spawning between different sizes of Pacific oyster, Crassostrea gigas (Thunberg). J. Shellfish Res. 26(2): 493-499.

Sousa, E.C.P.M.; Zaroni, L.P.; Gasparro, M.R.; Pereira, C.D.S. 2014. Review of ecotoxicological studies of the marine and estuarine environments of the Baixada Santista (São Paulo, Brazil). Brazilian J. Oceanogr. 62(2): 133-147.

Sparks, C.; Marnwick, J.; Odendaal, J.; Snyman, R. 2018. Antioxidant responses in Mytilus galloprovincialis exposed to copper. Fresenius Environ. Bull. 27(1): 488-502.

Stegeman, J.J.; Hahn, M.E. 1994. Biochemistry and molecular biology of monooxygenase: current perspective on forms, functions, and regulation of cytochrome P450 in aquatic species, in: Malins, D.C., Ostrander, G.K. (Eds.), Aquatic Toxicology - Molecular, Biochemical and Cellular Perspectives. Boca Raton, FL: Lewis Publishers, pp. 87-206.

Stresser, D.M.; Blanchard, A.P.; Turner, S.D.; Erve, J.C.L.; Dandeneau, A.A.; Miller, V.P.; Crespi, C.L. 2000. Substrate-dependent modulation of CYP3A4 catalytic activity: analysis of 27 test compounds with four fluorimetric substrates. Drug Metab. Dispos. 28(12): 1440-1448.

Stumm, W.; Morgan, J.J. 1995. Aquatic Chemistry: Chemical Equilibria and Rates in Natural Waters, 3rd ed. New York, NY: Wiley-Interscience.

Subtil, E.L.; Mierzwa, J.C.; Ortiz, J.P. 2012. Influência do nível de tratamento de esgoto na qualidade da água do mar na região de lançamento do Emissário Submarino de Santos. Rev. Ambient. e Água 7(3): 72-86.

Thibaut, R.; Schnell, S.; Porte, C. 2006. The interference of pharmaceuticals with endogenous and xenobiotic metabolizing enzymes in carp liver: an in-vitro study. Environ. Sci. Technol. 40(16): $5154-5460$.

Timbrell, J.A. 2009. Principles of biochemical toxicology, 4th ed. New York, NY: Informa Healthcare.

Tommasi, L.R. 1979. Considerações ecológicas sobre o Sistema Estuarino de Santos (SP). São Paulo, SP: Universidade de São Paulo (USP).

Torres, R.J.; Abessa, D.M.S.; Santos, F.C.; Maranho, L.A.; Davanso, M.B.; Nascimento, M.R.L.; Mozeto, A.A. 2009. Effects of dredging operations on sediment quality: contaminant mobilization in dredged sediments from the Port of Santos, SP, Brazil. J. Soils Sediments 9(5): 420-432.

Torres, R.J.; Cesar, A.; Pastor, V.A.; Pereira, C.D.S.; Choueri, R.B.; Cortez, F.S.; Morais, R.D.; Abessa, D.M.S.; Nascimento, M.R.L.; Morais, C.R.; Fadini, P.S.; DelValls, T.Á.; Mozeto, A.A. 2015. A critical comparison of different approaches to sediment-quality assessments in the Santos estuarine system in Brazil. Arch. Environ. Contam. Toxicol. 68(1): 132-147.

Trevisan, R.; Flesch, S.; Mattos, J.J.; Milani, M.R.; Bainy, A.C.D.; Dafre, A.L. 2014. Zinc causes acute impairment of glutathione metabolism followed by coordinated antioxidant defenses amplification in gills of brown mussels Perna perna. Comp. Biochem. Physiol. C 159(1): 22-30.

Turja, R.; Soirinsuo, A.; Budzinski, H.; Devier, M.H.; Lehtonen, K.K. 2013. Biomarker responses and accumulation of hazardous substances in mussels (Mytilus trossulus) transplanted along a pollution gradient close to an oil terminal in the Gulf of Finland (Baltic Sea). Comp. Biochem. Physiol. C 157(1): 80-92.

UNEP (United Nations Environmental Programme). 2007. Decision IG 17/7: Operational Document of MED POL Phase IV ( 2006-2013 ). Hammamet,TUN: UNEP.

Valavanidis, A.; Vlachogianni, T. 2010. Integrated biomarkers in aquatic organisms as a tool for biomonitoring environmental pollution and improved ecological risk assessment. Environ. Chem. 
Toxicol. Ecotoxicol. 1-12.

Valavanidis, A.; Vlachogianni, T.; Dassenakis, M.; Scoullos, M. 2006. Molecular biomarkers of oxidative stress in aquatic organisms in relation to toxic environmental pollutants. Ecotoxicol. Environ. Saf. 64(2): 178-189.

Valbonesi, P.; Sartor, G.; Fabbri, E. 2003. Characterization of cholinesterase activity in three bivalves inhabiting the North Adriatic sea and their possible use as sentinel organisms for biosurveillance programmes. Sci. Total Environ. 312(1-3): 79-88.

van der Oost, R.; Beyer, J.; Vermeulen, N.P.E. 2003. Fish bioaccumulation and biomarkers in environmental risk assessment: a review. Environ. Toxicol. Pharmacol. 13(2): 57-149.

van Welie, R.T.H.; van Dijck, R.G.J.M.; Vermeulen, N.P.E.; van Sittert, N.J. 1992. Mercapturic acids, protein adducts, and DNA adducts as biomarkers of electrophilic chemicals. Crit. Rev. Toxicol. 22(5-6): 271-306.

Viarengo, A.; Bettella, E.; Fabbri, R.; Burlando, B.; Lafaurie, M. 1997. Heavy metal inhibition of EROD activity in liver microsomes from the bass Dicentrarchus labrax exposed to organic xenobiotics: role of GSH in the reduction of heavy metal effects. Mar. Environ. Res. 44(1): 1-11.

Viarengo, A.; Lowe, D.M.; Bolognesi, C.; Fabbri, E.; Koehler, A. 2007. The use of biomarkers in biomonitoring: A 2-tier approach assessing the level of pollutant-induced stress syndrome in sentinel organisms. Comp. Biochem. Physiol. C 146(3): 281-300.

Viarengo, A.; Moore, M.N.; Mancinelli, G.; Mazzucotelli, A.; Pipe, R.K.; Farrar, S. V. 1987. Metallothioneins and lysosomes in metal toxicity and accumulation in marine mussels: the effect of cadmium in the presence and absence of phenanthrene. Mar. Biol. 94: 251-257.

Wallace, K.J. 2007. Classification of ecosystem services: problems and solutions. Biol. Conserv. 139(34): 235-246.

Wang, M.; Wang, G. 2010. Oxidative damage effects in the copepod Tigriopus japonicus Mori experimentally exposed to nickel. Ecotoxicol. 19(2): 273-284.

Webster, L.; Fryer, R.; Davies, I.M.; Roose, P.; Moffat, C. 2009. Background Document on CEMP Assessment Criteria for QSR 2010, Monitoring and Assessment Series. London, UK: OSPAR Commission.

WHO (World Health Organization). 1993. Biomarkers and risk assessment: concepts and principles (EHC 155). Geneva, Switzerland.

Wilhelm Filho, D.; Tribess, T.; Gáspari, C.; Claudio, F.D.; Torres, M.A.; Magalhães, A.R.M. 2001. Seasonal changes in antioxidant defenses of the digestive gland of the brown mussel (Perna perna). Aquaculture 203: 149-158.

Wills, E.D. 1987. Evaluation of lipid peroxidation in lipids and biological membranes, in: Snell, K., Mullock, B. (Eds.), Biochemical Toxicology: A Practical Approach. Washinton, DC (USA): IRL Press, pp. 127-150.

Wu, X.; Cobbina, S.J.; Mao, G.; Xu, H.; Zhang, Z.; Yang, L. 2016. A review of toxicity and mechanisms of individual and mixtures of heavy metals in the environment. Environ. Sci. Pollut. Res. 23(9): 8244-8259.

Yogui, G.T.; Santos, M.C.O.; Montone, R.C. 2003. Chlorinated pesticides and polychlorinated biphenyls in marine tucuxi dolphins (Sotalia fluviatilis) from the Cananéia estuary, southeastern Brazil. Sci. Total Environ. 312(1-3): 67-78.

Yusof, A.M.; Yanta, N.F.; Wood, A.K.H. 2004. The use of bivalves as bio-indicators in the assessment of marine pollution along a coastal area. J. Radioanal. Nucl. Chem. 259(1): 119-127.

Zanette, J.; Monserrat, J.M.; Bianchini, A. 2006. Biochemical biomarkers in gills of mangrove oyster Crassostrea rhizophorae from three Brazilian estuaries. Comp. Biochem. Physiol. C 143(2): 187195.

Zar, J.H. 1996. Biostatystical analysis, 3rd ed. New Jersey: Prentice-Hall.

Zaroni, L.P. 2006. Avaliação da qualidade dos sedimentos marinhos e estuarinos no município de Bertioga - SP. São Paulo, SP: Universidade de São Paulo (USP). 
Zhang, X.-J.; Greenberg, D.S. 2012. Acetylcholinesterase involvement in apoptosis. Front. Mol. Neurosci. 5(40): 1-6.

Zhang, X.J.; Yang, L.; Zhao, Q.; Caen, J.P.; He, H.Y.; Jin, Q.H.; Guo, L.H.; Alemany, M.; Zhang, L.Y.; Shi, Y.F. 2002. Induction of acetylcholinesterase expression during apoptosis in various cell types. Cell Death Differ. 9(8): 790-800. 


\section{APÊNDICE A}

Comprimento $(\mathrm{cm})$ e altura $(\mathrm{cm})$ das conchas de cada mexilhão P. perna e cada ostra $\mathrm{C}$. brasiliana utilizados em todas as análises realizadas. 
Tabela 14. Comprimento $(\mathrm{cm})$ e altura $(\mathrm{cm})$ das conchas de cada mexilhão $P$. perna e cada ostra $C$. brasiliana utilizados nas análises de bioacumulação de metais.

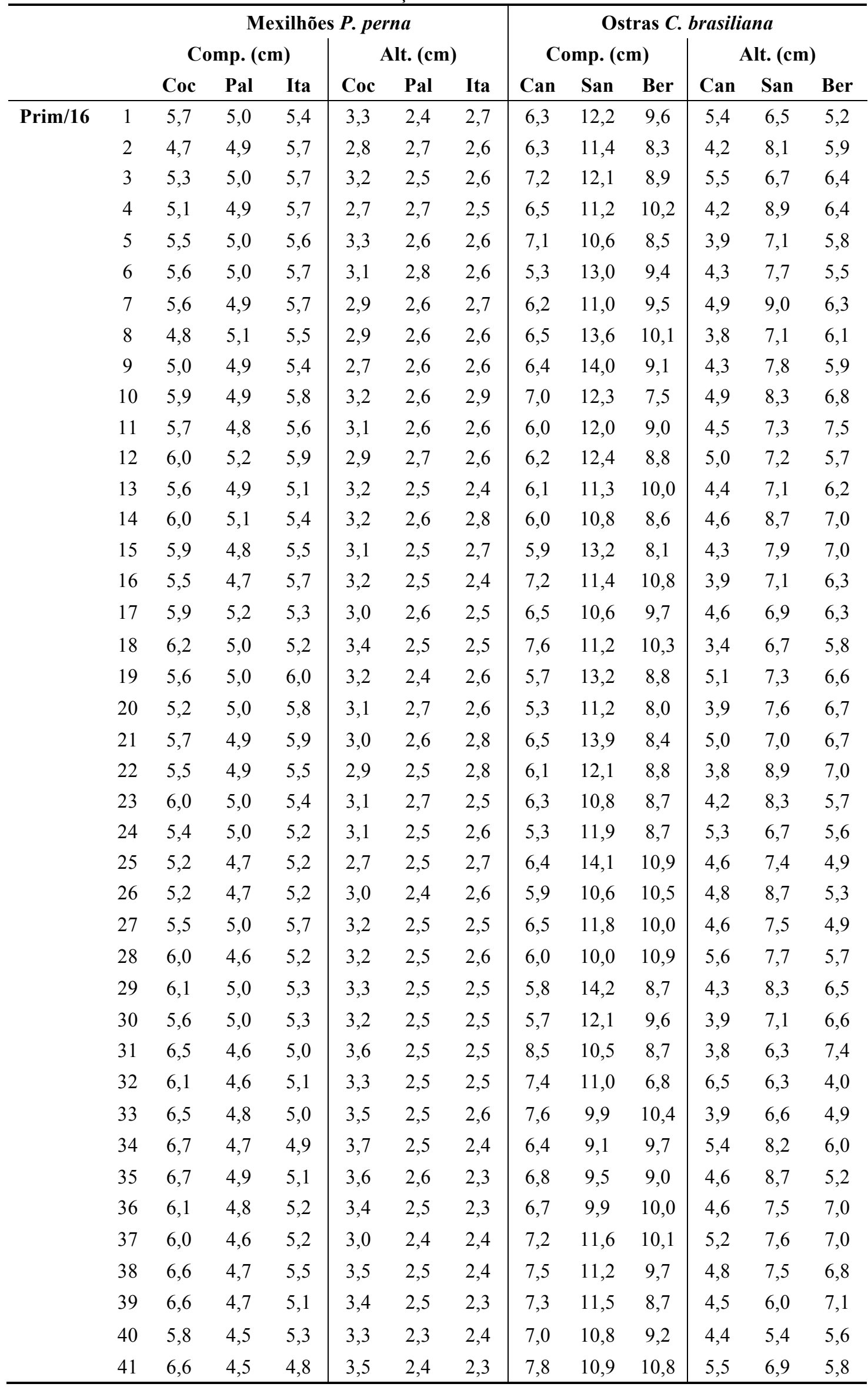




\begin{tabular}{|c|c|c|c|c|c|c|c|c|c|c|c|c|}
\hline & \multicolumn{6}{|c|}{ Mexilhões $P$. perna } & \multicolumn{6}{|c|}{ Ostras $C$. brasiliana } \\
\hline & \multicolumn{3}{|c|}{ Comp. (cm) } & \multicolumn{3}{|c|}{ Alt. (cm) } & \multicolumn{3}{|c|}{ Comp. (cm) } & \multicolumn{3}{|c|}{ Alt. (cm) } \\
\hline & Coc & Pal & Ita & Coc & Pal & Ita & Can & San & Ber & Can & San & Ber \\
\hline 42 & 6,6 & 4,8 & 5,2 & 3,4 & 2,5 & 2,5 & 7,7 & 10,0 & 9,7 & 4,8 & 6,3 & 6,2 \\
\hline 43 & 6,7 & 4,6 & 5,1 & 3,5 & 2,5 & 2,5 & 7,7 & 13,1 & 10,2 & 5,5 & 6,2 & 7,0 \\
\hline 44 & 6,8 & 4,5 & 4,7 & 3,5 & 2,4 & 2,3 & 8,1 & 13,0 & 8,8 & 4,5 & 5,5 & 7,2 \\
\hline 45 & 6,5 & 4,6 & 5,2 & 3,6 & 2,4 & 2,5 & 7,7 & 11,5 & 8,3 & 5,8 & 7,4 & 7,3 \\
\hline 46 & 6,2 & 4,6 & 5,1 & 3,5 & 2,4 & 2,5 & 8,4 & 10,3 & 9,4 & 4,3 & 7,2 & 6,0 \\
\hline 47 & 6,6 & 4,8 & 4,8 & 3,5 & 2,3 & 2,5 & 7,8 & 10,1 & 8,4 & 5,2 & 7,1 & 6,7 \\
\hline 48 & 6,1 & 4,6 & 5,1 & 3,4 & 2,5 & 2,5 & 7,3 & 12,0 & 9,2 & 4,2 & 6,4 & 6,8 \\
\hline 49 & 6,7 & 4,5 & 5,4 & 3,4 & 2,3 & 2,4 & 6,4 & 11,9 & 10,6 & 5,0 & 6,1 & 5,0 \\
\hline 50 & 6,0 & 4,6 & 5,1 & 3,3 & 2,3 & 2,5 & 6,1 & 9,3 & 8,5 & 6,1 & 6,9 & 5,9 \\
\hline 51 & 6,3 & 4,6 & 4,9 & 3,3 & 2,4 & 2,3 & 6,5 & 10,5 & 9,5 & 4,2 & 5,9 & 6,9 \\
\hline 52 & 6,2 & 4,4 & 5,2 & 3,5 & 2,4 & 2,4 & 7,3 & 9,7 & 8,8 & 5,1 & 7,4 & 7,3 \\
\hline 53 & 6,6 & 4,6 & 5,0 & 3,5 & 2,5 & 2,5 & 7,4 & 10,3 & 9,1 & 3,8 & 6,6 & 8,7 \\
\hline 54 & 6,5 & 4,6 & 5,1 & 3,5 & 2,4 & 2,5 & 7,5 & 10,9 & 9,0 & 5,1 & 5,3 & 5,9 \\
\hline 55 & 6,7 & 4,7 & 5,0 & 3,6 & 2,4 & 2,3 & 6,8 & 9,7 & 8,9 & 4,9 & 7,5 & 7,2 \\
\hline 56 & 6,7 & 4,6 & 4,7 & 3,6 & 2,5 & 2,5 & 7,2 & 11,2 & 10,5 & 4,3 & 8,0 & 5,5 \\
\hline 57 & 6,7 & 4,5 & 5,1 & 3,8 & 2,5 & 2,4 & 7,3 & 10,2 & 8,5 & 4,6 & 8,6 & 7,5 \\
\hline 58 & 6,8 & 4,8 & 5,0 & 3,8 & 2,4 & 2,4 & 7,5 & 11,4 & 10,9 & 5,2 & 7,6 & 6,3 \\
\hline 59 & 6,7 & 4,7 & 5,0 & 3,4 & 2,5 & 2,5 & 7,1 & 10,4 & 9,0 & 4,9 & 7,6 & 7,2 \\
\hline 60 & 6,9 & 4,6 & 4,8 & 3,5 & 2,3 & 2,3 & 6,8 & 11,6 & 10,3 & 5,0 & 6,4 & 5,0 \\
\hline 61 & 7,7 & 4,4 & 4,8 & 4,0 & 2,2 & 2,2 & 8,0 & 12,8 & 12,4 & 5,4 & 7,2 & 6,7 \\
\hline 62 & 7,7 & 4,7 & 5,0 & 3,8 & 2,4 & 2,3 & 7,9 & 7,0 & 10,8 & 4,9 & 4,7 & 7,0 \\
\hline 63 & 7,5 & 4,3 & 4,5 & 3,7 & 2,3 & 2,3 & 8,0 & 9,2 & 11,5 & 4,3 & 4,8 & 6,0 \\
\hline 64 & 7,4 & 4,4 & 5,0 & 4,0 & 2,2 & 2,4 & 7,6 & 9,6 & 10,2 & 5,4 & 5,4 & 7,0 \\
\hline 65 & 7,5 & 4,6 & 4,6 & 3,6 & 2,4 & 2,3 & 7,9 & 8,9 & 9,3 & 5,0 & 5,7 & 7,2 \\
\hline 66 & 7,7 & 4,4 & 4,5 & 4,0 & 2,3 & 2,2 & 7,9 & 7,9 & 9,8 & 6,0 & 7,2 & 6,8 \\
\hline 67 & 7,0 & 4,5 & 4,8 & 3,8 & 2,3 & 2,4 & 8,8 & 6,3 & 12,3 & 4,4 & 6,7 & 5,6 \\
\hline 68 & 7,5 & 4,4 & 4,9 & 3,7 & 2,3 & 2,6 & 7,6 & 6,7 & 10,7 & 5,3 & 8,8 & 6,8 \\
\hline 69 & 8,0 & 4,5 & 4,8 & 3,9 & 2,3 & 2,5 & 8,7 & 8,1 & 12,8 & 4,9 & 4,9 & 5,4 \\
\hline 70 & 7,2 & 4,6 & 4,5 & 3,9 & 2,4 & 2,3 & 8,2 & 6,9 & 9,8 & 4,2 & 6,6 & 5,9 \\
\hline 71 & 7,2 & 4,5 & 4,8 & 3,6 & 2,3 & 2,3 & 8,4 & 7,7 & 9,8 & 5,1 & 5,9 & 6,1 \\
\hline 72 & 7,1 & 4,6 & 4,5 & 3,9 & 2,4 & 2,1 & 9,5 & 8,4 & 11,7 & 4,4 & 6,7 & 6,5 \\
\hline 73 & 7,6 & 4,3 & 5,6 & 3,9 & 2,3 & 2,5 & 8,1 & 8,6 & 9,4 & 5,2 & 5,4 & 7,9 \\
\hline 74 & 7,7 & 4,3 & 4,4 & 4,0 & 2,2 & 2,2 & 9,0 & 9,1 & 9,5 & 5,2 & 6,7 & 6,1 \\
\hline 75 & 7,4 & 4,5 & 4,4 & 3,9 & 2,3 & 2,2 & 8,2 & 9,2 & 11,9 & 4,0 & 5,1 & 5,0 \\
\hline 76 & 7,3 & 4,2 & 4,6 & 3,7 & 2,2 & 2,4 & 8,5 & 8,9 & 10,8 & 5,5 & 6,4 & 7,1 \\
\hline 77 & 7,6 & 4,5 & 4,6 & 3,6 & 2,4 & 2,4 & 7,8 & 8,7 & 10,2 & 4,4 & 5,5 & 7,5 \\
\hline 78 & 7,4 & 4,2 & 4,8 & 3,7 & 2,1 & 2,3 & 7,7 & 6,3 & 11,5 & 5,2 & 6,8 & 6,7 \\
\hline 79 & 7,2 & 4,4 & 4,9 & 3,9 & 2,3 & 2,3 & 8,9 & 8,9 & 10,9 & 4,8 & 6,4 & 6,3 \\
\hline 80 & 7,2 & 4,4 & 4,9 & 3,6 & 2,2 & 2,3 & 7,3 & 8,1 & 11,3 & 5,6 & 5,9 & 5,1 \\
\hline 81 & 7,0 & 4,4 & 4,6 & 3,6 & 2,4 & 2,2 & 8,4 & 8,5 & 10,5 & 4,4 & 5,8 & 5,7 \\
\hline 82 & 7,4 & 4,2 & 4,6 & 3,6 & 2,2 & 2,3 & 7,9 & 7,0 & 9,6 & 5,4 & 5,3 & 6,0 \\
\hline 83 & 7,2 & 4,5 & 4,7 & 3,9 & 2,3 & 2,5 & 8,5 & 8,8 & 10,9 & 4,4 & 7,9 & 5,1 \\
\hline 84 & 7,3 & 4,2 & 4,5 & 3,8 & 2,2 & 2,5 & 8,5 & 7,9 & 11,2 & 5,8 & 5,2 & 6,4 \\
\hline
\end{tabular}




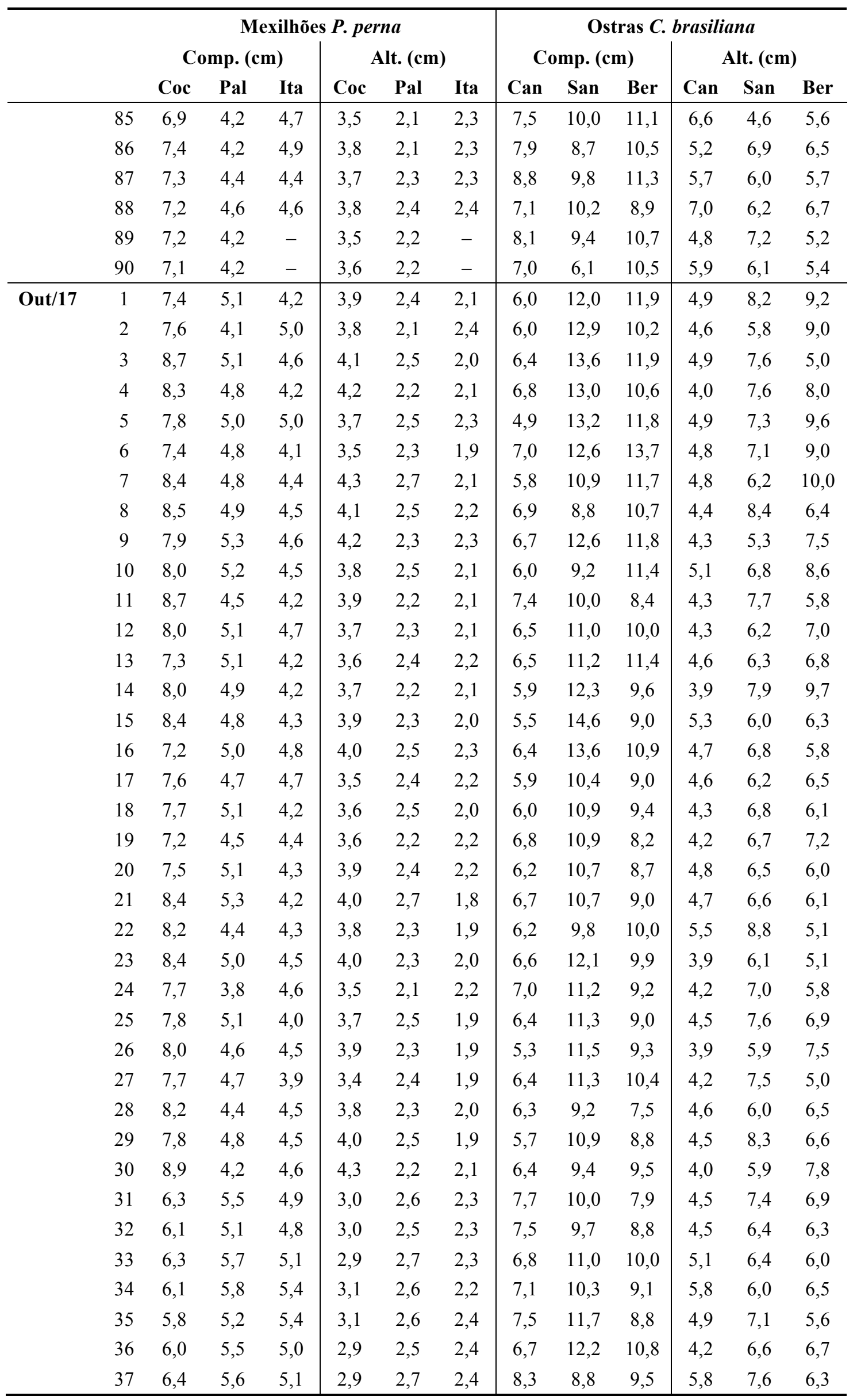




\begin{tabular}{|c|c|c|c|c|c|c|c|c|c|c|c|c|}
\hline & \multicolumn{6}{|c|}{ Mexilhões $P$. perna } & \multicolumn{6}{|c|}{ Ostras $C$. brasiliana } \\
\hline & \multicolumn{3}{|c|}{ Comp. (cm) } & \multicolumn{3}{|c|}{ Alt. (cm) } & \multicolumn{3}{|c|}{ Comp. (cm) } & \multicolumn{3}{|c|}{ Alt. (cm) } \\
\hline & Coc & Pal & Ita & Coc & Pal & Ita & Can & San & Ber & Can & San & Ber \\
\hline 38 & 6,4 & 5,7 & 4,8 & 3,2 & 2,6 & 2,2 & 7,4 & 8,8 & 9,0 & 4,1 & 7,0 & 7,4 \\
\hline 39 & 7,0 & 5,4 & 4,9 & 3,4 & 2,5 & 2,5 & 7,5 & 10,5 & 8,4 & 5,4 & 6,4 & 6,2 \\
\hline 40 & 6,3 & 5,9 & 4,7 & 3,0 & 2,8 & 2,1 & 6,9 & 11,5 & 9,7 & 5,0 & 6,2 & 7,7 \\
\hline 41 & 6,3 & 5,4 & 5,5 & 3,1 & 2,7 & 2,4 & 7,1 & 9,7 & 12,3 & 6,3 & 7,8 & 7,7 \\
\hline 42 & 6,4 & 5,6 & 5,1 & 3,2 & 2,5 & 2,4 & 6,4 & 11,0 & 10,4 & 5,0 & 6,6 & 7,4 \\
\hline 43 & 6,1 & 6,0 & 5,0 & 3,3 & 2,7 & 2,3 & 7,1 & 9,2 & 9,1 & 5,5 & 6,8 & 5,5 \\
\hline 44 & 6,6 & 5,1 & 5,4 & 3,4 & 2,5 & 2,4 & 6,6 & 12,8 & 8,3 & 4,7 & 4,8 & 5,7 \\
\hline 45 & 6,0 & 5,5 & 5,7 & 3,1 & 2,5 & 2,4 & 7,8 & 9,7 & 8,6 & 4,1 & 8,0 & 5,5 \\
\hline 46 & 6,3 & 5,5 & 5,0 & 3,1 & 2,5 & 2,3 & 6,3 & 10,5 & 8,7 & 4,7 & 6,2 & 5,0 \\
\hline 47 & 6,4 & 5,4 & 4,8 & 2,9 & 2,5 & 2,3 & 7,8 & 9,9 & 6,7 & 4,5 & 7,1 & 6,1 \\
\hline 48 & 6,3 & 5,8 & 4,3 & 3,0 & 2,7 & 2,4 & 6,6 & 11,3 & 7,6 & 5,5 & 6,7 & 5,6 \\
\hline 49 & 6,2 & 5,5 & 4,7 & 2,9 & 2,6 & 2,2 & 7,2 & 8,7 & 8,3 & 5,0 & 6,0 & 5,8 \\
\hline 50 & 6,4 & 5,3 & 4,9 & 3,0 & 2,6 & 2,3 & 7,2 & 11,2 & 7,5 & 4,4 & 7,7 & 6,7 \\
\hline 51 & 6,3 & 5,4 & 5,2 & 3,0 & 2,4 & 2,5 & 7,5 & 9,9 & 8,4 & 4,0 & 6,2 & 5,2 \\
\hline 52 & 6,2 & 5,4 & 5,0 & 3,0 & 2,6 & 2,2 & 6,9 & 10,2 & 8,0 & 4,0 & 6,8 & 6,2 \\
\hline 53 & 6,1 & 5,4 & 5,0 & 2,9 & 2,6 & 2,1 & 7,1 & 9,9 & 7,4 & 5,1 & 6,6 & 5,9 \\
\hline 54 & 6,6 & 5,5 & 5,4 & 3,1 & 2,7 & 2,4 & 7,0 & 9,1 & 8,0 & 4,7 & 8,1 & 6,0 \\
\hline 55 & 6,2 & 5,3 & 5,1 & 3,1 & 2,5 & 2,3 & 6,9 & 10,0 & 9,0 & 5,5 & 6,5 & 5,3 \\
\hline 56 & 6,5 & 5,5 & 5,0 & 2,9 & 2,5 & 2,1 & 6,9 & 10,1 & 7,6 & 5,3 & 5,7 & 7,6 \\
\hline 57 & 6,8 & 5,3 & 5,1 & 3,1 & 2,5 & 2,3 & 6,7 & 9,6 & 8,4 & 5,4 & 6,7 & 5,2 \\
\hline 58 & 6,2 & 5,6 & 4,7 & 3,2 & 2,7 & 2,4 & 6,5 & 9,1 & 7,3 & 5,5 & 5,8 & 6,2 \\
\hline 59 & 6,3 & 5,3 & 4,8 & 2,9 & 2,5 & 2,1 & 7,5 & 8,3 & 7,6 & 5,8 & 6,5 & 5,6 \\
\hline 60 & 6,5 & 5,2 & 5,0 & 3,1 & 2,5 & 2,1 & 6,4 & 8,8 & 7,4 & 4,9 & 7,0 & 6,2 \\
\hline 61 & 4,1 & 6,8 & 6,8 & 2,5 & 3,0 & 2,8 & 7,9 & 9,4 & 8,7 & 5,3 & 5,8 & 5,2 \\
\hline 62 & 3,6 & 6,6 & 7,1 & 2,1 & 2,8 & 3,0 & 7,2 & 10,0 & 8,1 & 6,0 & 7,2 & 6,5 \\
\hline 63 & 4,3 & 7,0 & 7,1 & 2,2 & 3,0 & 3,0 & 9,3 & 9,1 & 7,6 & 5,5 & 6,4 & 6,9 \\
\hline 64 & 4,3 & 7,0 & 6,9 & 2,3 & 3,1 & 2,9 & 8,8 & 7,8 & 7,2 & 4,8 & 7,6 & 5,4 \\
\hline 65 & 5,2 & 6,7 & 6,5 & 2,4 & 2,9 & 2,8 & 7,7 & 8,4 & 8,6 & 4,3 & 7,7 & 5,5 \\
\hline 66 & 4,4 & 6,4 & 6,8 & 2,1 & 3,1 & 3,1 & 8,1 & 9,8 & 8,4 & 5,1 & 5,9 & 6,2 \\
\hline 67 & 4,9 & 6,7 & 6,6 & 2,5 & 3,1 & 2,9 & 9,7 & 9,6 & 8,0 & 5,8 & 5,1 & 5,0 \\
\hline 68 & 4,6 & 6,7 & 6,6 & 2,5 & 3,1 & 2,8 & 9,3 & 9,4 & 7,9 & 5,2 & 5,5 & 5,5 \\
\hline 69 & 4,2 & 6,7 & 6,3 & 2,5 & 3,2 & 2,8 & 8,3 & 7,8 & 7,2 & 4,7 & 4,5 & 5,7 \\
\hline 70 & 4,9 & 6,5 & 6,6 & 2,4 & 2,7 & 3,0 & 8,9 & 7,3 & 8,3 & 6,1 & 4,6 & 5,0 \\
\hline 71 & 4,5 & 6,6 & 6,1 & 2,2 & 3,0 & 2,6 & 7,8 & 9,0 & 8,4 & 4,5 & 6,1 & 5,2 \\
\hline 72 & 4,1 & 6,7 & 6,9 & 2,3 & 2,9 & 3,1 & 8,7 & 9,6 & 8,4 & 5,4 & 5,5 & 6,1 \\
\hline 73 & 4,2 & 6,5 & 7,0 & 2,3 & 3,2 & 3,0 & 9,0 & 7,3 & 8,5 & 5,2 & 6,6 & 5,3 \\
\hline 74 & 4,0 & 6,4 & 7,2 & 2,2 & 3,0 & 3,0 & 8,7 & 8,0 & 7,9 & 5,1 & 4,5 & 6,4 \\
\hline 75 & 4,5 & 6,8 & 6,4 & 2,3 & 2,9 & 2,9 & 8,0 & 9,7 & 7,9 & 5,0 & 6,0 & 6,5 \\
\hline 76 & 4,2 & 6,7 & 6,3 & 2,3 & 3,0 & 2,9 & 8,6 & 7,8 & 7,5 & 4,6 & 5,1 & 5,2 \\
\hline 77 & 4,0 & 6,5 & 7,1 & 2,1 & 3,2 & 2,8 & 9,7 & 10,0 & 6,6 & 5,5 & 5,4 & 6,9 \\
\hline 78 & 4,6 & 7,0 & 6,4 & 2,4 & 3,0 & 2,9 & 9,9 & 6,9 & 7,0 & 5,6 & 4,8 & 6,4 \\
\hline 79 & 4,5 & 6,2 & 7,3 & 2,5 & 2,9 & 3,0 & 9,2 & 7,4 & 6,8 & 6,3 & 5,0 & 5,2 \\
\hline 80 & 4,7 & 6,8 & 7,0 & 2,4 & 2,9 & 3,2 & 7,3 & 9,4 & 7,2 & 6,2 & 6,2 & 5,8 \\
\hline
\end{tabular}




\begin{tabular}{|c|c|c|c|c|c|c|c|c|c|c|c|c|c|}
\hline & & \multicolumn{6}{|c|}{ Mexilhões $P$. perna } & \multicolumn{6}{|c|}{ Ostras $C$. brasiliana } \\
\hline & & \multicolumn{3}{|c|}{ Comp. (cm) } & \multicolumn{3}{|c|}{ Alt. (cm) } & \multicolumn{3}{|c|}{ Comp. (cm) } & \multicolumn{3}{|c|}{ Alt. (cm) } \\
\hline & & Coc & Pal & Ita & Coc & Pal & Ita & Can & San & Ber & Can & San & Ber \\
\hline & 81 & 4,6 & 6,9 & 7,0 & 2,4 & 3,1 & 3,1 & 8,8 & 8,5 & 6,4 & 5,4 & 5,3 & 5,0 \\
\hline & 82 & 4,6 & 6,8 & 6,3 & 2,5 & 2,9 & 2,7 & 8,3 & 9,6 & 6,2 & 5,9 & 5,5 & 4,4 \\
\hline & 83 & 4,4 & 6,9 & 6,0 & 2,3 & 3,0 & 2,8 & 8,3 & 9,2 & 6,4 & 5,0 & 6,2 & 3,8 \\
\hline & 84 & 4,5 & 6,5 & 6,9 & 2,4 & 3,1 & 3,0 & 8,9 & 8,0 & 7,0 & 6,3 & 6,0 & 5,9 \\
\hline & 85 & 4,1 & 6,6 & 6,3 & 2,5 & 3,1 & 2,7 & 7,9 & 9,1 & 7,7 & 4,8 & 4,6 & 5,3 \\
\hline & 86 & 4,1 & 6,5 & 6,7 & 2,2 & 3,2 & 2,7 & 7,9 & 5,4 & 6,8 & 5,2 & 8,4 & 4,3 \\
\hline & 87 & 3,9 & 6,7 & 6,6 & 2,4 & 3,2 & 3,1 & 8,8 & 9,5 & 7,3 & 7,3 & 5,3 & 4,3 \\
\hline & 88 & 4,0 & 6,5 & 6,8 & 2,1 & 2,9 & 2,8 & 7,6 & 8,6 & 7,3 & 4,9 & 5,3 & 4,9 \\
\hline & 89 & 4,0 & 6,7 & 5,9 & 2,0 & 2,9 & 2,8 & 8,5 & 9,3 & 6,0 & 5,3 & 7,3 & 4,0 \\
\hline & 90 & 3,8 & 6,8 & 7,2 & 2,4 & 2,9 & 2,9 & 7,9 & 8,8 & 6,4 & 6,1 & 6,4 & 5,6 \\
\hline média & & & 5,58 & & & 2,75 & & & 8,92 & & & 5,95 & \\
\hline mínimo & & & 3,60 & & & 1,80 & & & 4,90 & & & 3,40 & \\
\hline máximo & & & 8,90 & & & 4,30 & & & 14,60 & & & 10,00 & \\
\hline
\end{tabular}

Tabela 15. Comprimento $(\mathrm{cm})$ e altura $(\mathrm{cm})$ das conchas de cada mexilhão $P$. perna e cada ostra $C$. brasiliana utilizados nas análises de biomarcadores bioquímicos.

\begin{tabular}{|c|c|c|c|c|c|c|c|c|c|c|c|c|c|}
\hline & & \multicolumn{6}{|c|}{ Mexilhões $P$. perna } & \multicolumn{6}{|c|}{ Ostras $C$. brasiliana } \\
\hline & & \multicolumn{3}{|c|}{ Comp. (cm) } & \multicolumn{3}{|c|}{ Alt. (cm) } & \multicolumn{3}{|c|}{ Comp. (cm) } & \multicolumn{3}{|c|}{ Alt. (cm) } \\
\hline & & Coc & Pal & Ita & Coc & Pal & Ita & Can & San & Ber & Can & San & Ber \\
\hline \multirow[t]{10}{*}{ Prim/08 } & 1 & 8,4 & 7,8 & 8,1 & 4,1 & 3,7 & 3,4 & 9,0 & 5,3 & 10,8 & 6,9 & 2,8 & 5,4 \\
\hline & 2 & 8,2 & 7,4 & 6,9 & 4,5 & 3,6 & 3,0 & 9,2 & 4,2 & 9,9 & 6,5 & 3,9 & 4,5 \\
\hline & 3 & 9,5 & 7,1 & 6,5 & 5,0 & 3,0 & 3,1 & 8,9 & 4,9 & 7,9 & 6,1 & 3,2 & 4,9 \\
\hline & 4 & 9,2 & 8,4 & 7,4 & 4,8 & 3,7 & 3,5 & 9,0 & 4,6 & 8,4 & 6,5 & 4,0 & 4,5 \\
\hline & 5 & 9,0 & 6,8 & 7,4 & 4,5 & 3,2 & 3,2 & 7,6 & 5,3 & 8,3 & 6,5 & 3,7 & 5,0 \\
\hline & 6 & 9,7 & 6,8 & 7,6 & 4,8 & 3,1 & 3,3 & 9,7 & 5,2 & 8,0 & 5,7 & 4,2 & 6,5 \\
\hline & 7 & 9,1 & 7,1 & 7,9 & 5,0 & 3,0 & 3,2 & 9,7 & 4,8 & 8,2 & 5,4 & 3,6 & 5,5 \\
\hline & 8 & 8,7 & 6,7 & 8,0 & 4,6 & 3,1 & 3,4 & 10,1 & 4,9 & 7,6 & 5,8 & 4,6 & 6,0 \\
\hline & 9 & 8,5 & 6,8 & 6,8 & 4,2 & 3,0 & 3,2 & 8,1 & 4,8 & 8,8 & 7,9 & 4,1 & 6,3 \\
\hline & 10 & 9,2 & 6,5 & 7,0 & 5,1 & 3,2 & 3,0 & 8,3 & 4,7 & 8,3 & 6,7 & 4,2 & 5,1 \\
\hline \multirow[t]{10}{*}{ Ver/09 } & 1 & 8,2 & 7,9 & 6,8 & 3,4 & 3,1 & 2,9 & 8,8 & 6,5 & 7,0 & 4,9 & 6,3 & 4,3 \\
\hline & 2 & 8,0 & 6,5 & 8,1 & 3,1 & 3,1 & 3,4 & 9,2 & 5,3 & 7,0 & 6,4 & 6,0 & 5,8 \\
\hline & 3 & 8,0 & 7,7 & 7,6 & 3,9 & 2,9 & 3,3 & 8,7 & 4,5 & 7,3 & 6,7 & 6,7 & 5,4 \\
\hline & 4 & 7,8 & 6,3 & 7,1 & 3,5 & 2,7 & 3,0 & 8,8 & 5,5 & 6,7 & 5,9 & 6,7 & 5,1 \\
\hline & 5 & 7,9 & 7,0 & 7,1 & 3,5 & 3,2 & 3,2 & 8,1 & 6,7 & 5,9 & 6,4 & 6,0 & 4,9 \\
\hline & 6 & 7,7 & 7,0 & 8,0 & 3,3 & 2,8 & 3,3 & 8,5 & 6,5 & 6,7 & 6,3 & 4,9 & 6,8 \\
\hline & 7 & 8,0 & 6,7 & 6,3 & 3,8 & 3,0 & 2,9 & 8,3 & 7,2 & 7,6 & 6,6 & 5,0 & 4,5 \\
\hline & 8 & 7,7 & 6,3 & 6,9 & 3,5 & 3,1 & 3,2 & 7,9 & 4,8 & 7,8 & 7,5 & 3,6 & 4,6 \\
\hline & 9 & 7,6 & 7,3 & 5,3 & 3,2 & 3,3 & 2,9 & 8,7 & 6,4 & 7,1 & 6,4 & 4,3 & 4,2 \\
\hline & 10 & 7,9 & 6,5 & 6,9 & 3,1 & 2,8 & 3,0 & 7,9 & 5,7 & 7,0 & 5,9 & 4,5 & 4,9 \\
\hline \multirow[t]{3}{*}{ Inv/09 } & 1 & 7,5 & 6,5 & 8,8 & 3,5 & 3,5 & 3,7 & 6,2 & 6,4 & 8,4 & 5,8 & 4,5 & 5,9 \\
\hline & 2 & 7,6 & 6,2 & 8,0 & 3,8 & 3,3 & 3,5 & 7,5 & 5,9 & 7,9 & 4,7 & 4,4 & 6,5 \\
\hline & 3 & 7,4 & 6,1 & 7,6 & 3,5 & 2,9 & 3,2 & 7,8 & 4,9 & 7,9 & 5,4 & 4,3 & 6,2 \\
\hline
\end{tabular}




\begin{tabular}{|c|c|c|c|c|c|c|c|c|c|c|c|c|c|}
\hline & & \multicolumn{6}{|c|}{ Mexilhões $P$. perna } & \multicolumn{6}{|c|}{ Ostras $C$. brasiliana } \\
\hline & & \multicolumn{3}{|c|}{ Comp. (cm) } & \multicolumn{3}{|c|}{ Alt. (cm) } & \multicolumn{3}{|c|}{ Comp. (cm) } & \multicolumn{3}{|c|}{ Alt. (cm) } \\
\hline & & Coc & Pal & Ita & Coc & Pal & Ita & Can & San & Ber & Can & San & Ber \\
\hline & 4 & 8,6 & 7,0 & 7,9 & 4,2 & 3,6 & 3,2 & 7,6 & 4,5 & 7,9 & 4,5 & 3,7 & 6,0 \\
\hline & 5 & 8,5 & 6,7 & 7,8 & 3,9 & 4,1 & 2,9 & 7,2 & 4,3 & 8,0 & 4,3 & 4,2 & 7,2 \\
\hline & 6 & 7,9 & 6,9 & 7,6 & 4,0 & 3,8 & 3,4 & 8,0 & 7,5 & 8,2 & 3,3 & 4,2 & 6,4 \\
\hline & 7 & 7,5 & 6,7 & 7,6 & 3,9 & 3,5 & 3,3 & 8,0 & 6,4 & 7,8 & 4,3 & 4,4 & 4,7 \\
\hline & 8 & 8,7 & 6,4 & 7,2 & 3,8 & 3,4 & 3,1 & 7,7 & 6,8 & 7,5 & 5,0 & 4,5 & 6,3 \\
\hline & 9 & 8,2 & 6,4 & 7,1 & 3,8 & 3,9 & 3,3 & 6,7 & 7,6 & 7,1 & 4,0 & 4,2 & 5,7 \\
\hline & 10 & 8,1 & 6,3 & 7,4 & 3,6 & 3,0 & 3,0 & 7,2 & 6,6 & 7,8 & 5,0 & 3,6 & 6,3 \\
\hline \multirow[t]{10}{*}{ Prim/16 } & 1 & 9,2 & 5,4 & 5,8 & 4,1 & 2,7 & 2,6 & 9,0 & 11,2 & 9,3 & 5,0 & 9,0 & 5,0 \\
\hline & 2 & 8,9 & 5,1 & 6,2 & 4,6 & 2,7 & 2,8 & 7,9 & 13,0 & 9,9 & 5,3 & 6,9 & 6,4 \\
\hline & 3 & 9,3 & 5,3 & 5,9 & 4,4 & 2,7 & 2,8 & 9,1 & 11,5 & 8,9 & 5,5 & 7,9 & 6,4 \\
\hline & 4 & 8,4 & 5,0 & 6,3 & 4,1 & 2,6 & 2,9 & 8,0 & 12,2 & 9,8 & 5,7 & 8,6 & 5,0 \\
\hline & 5 & 8,3 & 5,1 & 6,9 & 4,3 & 2,8 & 3,0 & 8,9 & 14,2 & 9,8 & 5,4 & 6,8 & 6,0 \\
\hline & 6 & 7,9 & 5,0 & 6,0 & 4,5 & 2,5 & 2,6 & 8,7 & 14,5 & 7,8 & 5,3 & 9,0 & 5,8 \\
\hline & 7 & 8,3 & 5,0 & 6,0 & 4,3 & 2,7 & 2,6 & 9,4 & 13,5 & 9,6 & 5,3 & 6,9 & 5,0 \\
\hline & 8 & 7,9 & 5,0 & 5,9 & 4,3 & 2,6 & 2,8 & 8,9 & 13,2 & 10,0 & 5,8 & 7,4 & 5,9 \\
\hline & 9 & 8,2 & 4,9 & 5,8 & 4,1 & 2,5 & 3,0 & 8,2 & 13,2 & 9,3 & 4,8 & 8,7 & 5,8 \\
\hline & 10 & 8,5 & 4,8 & 5,8 & 3,9 & 2,6 & 2,8 & 8,0 & 12,4 & 9,1 & 5,9 & 9,5 & 5,7 \\
\hline \multirow[t]{10}{*}{ Out/17 } & 1 & 8,6 & 7,1 & 8,2 & 4,3 & 2,9 & 3,1 & 9,8 & 13,5 & 8,1 & 7,4 & 7,9 & 6,2 \\
\hline & 2 & 8,5 & 6,4 & 8,2 & 4,4 & 3,1 & 3,2 & 7,6 & 12,0 & 6,5 & 5,2 & 9,4 & 4,9 \\
\hline & 3 & 8,3 & 7,0 & 7,8 & 3,9 & 3,2 & 3,2 & 10,8 & 15,0 & 9,3 & 7,2 & 7,2 & 5,5 \\
\hline & 4 & 9,0 & 7,0 & 7,7 & 4,2 & 3,2 & 3,1 & 8,0 & 13,6 & 8,0 & 6,3 & 7,8 & 5,8 \\
\hline & 5 & 8,9 & 7,4 & 8,1 & 4,4 & 3,1 & 3,4 & 9,5 & 11,0 & 8,4 & 6,1 & 9,3 & 5,3 \\
\hline & 6 & 8,1 & 7,2 & 8,0 & 4,1 & 3,2 & 3,1 & 7,5 & 12,4 & 8,2 & 5,2 & 8,7 & 5,5 \\
\hline & 7 & 8,3 & 7,5 & 8,3 & 3,9 & 3,4 & 3,3 & 9,6 & 12,1 & 8,5 & 6,2 & 10,9 & 6,5 \\
\hline & 8 & 8,4 & 7,7 & 7,8 & 4,3 & 3,4 & 3,2 & 9,7 & 13,0 & 7,7 & 6,2 & 8,7 & 6,9 \\
\hline & 9 & 7,9 & 7,3 & 8,4 & 4,1 & 3,2 & 3,3 & 7,7 & 14,4 & 7,1 & 5,1 & 8,0 & 6,8 \\
\hline & 10 & 8,6 & 7,1 & 7,8 & 4,2 & 3,1 & 3,2 & 10,4 & 10,5 & 8,8 & 7,7 & 7,0 & 6,1 \\
\hline média & & & 7,4 & & & 3,4 & & & 8,4 & & & 5,8 & \\
\hline mínimo & & & 4,8 & & & 2,5 & & & 4,2 & & & 2,8 & \\
\hline máximo & & & 9,7 & & & 5,1 & & & 15,0 & & & 10,9 & \\
\hline
\end{tabular}

Tabela 16. Comprimento $(\mathrm{cm})$ e altura $(\mathrm{cm})$ das conchas de cada mexilhão $P$. perna e cada ostra $C$. brasiliana utilizados na análise do biomarcador fisiológico.

\begin{tabular}{|c|c|c|c|c|c|c|c|c|c|c|c|c|c|}
\hline & & \multicolumn{6}{|c|}{ Mexilhões $P$. perna } & \multicolumn{6}{|c|}{ Ostras $C$. brasiliana } \\
\hline & & \multicolumn{3}{|c|}{ Comp. (cm) } & \multicolumn{3}{|c|}{ Alt. (cm) } & \multicolumn{3}{|c|}{ Comp. (cm) } & \multicolumn{3}{|c|}{ Altura (cm) } \\
\hline & & Coc & Pal & Ita & Coc & Pal & Ita & Can & San & Ber & Can & San & Ber \\
\hline \multirow[t]{6}{*}{ Prim/16 } & 1 & 8,1 & 6,0 & 6,2 & 4,2 & 3,1 & 3,0 & 9,5 & 16,2 & 11,2 & 4,9 & 8,9 & 7,6 \\
\hline & 2 & 8,4 & 5,5 & 6,3 & 4,1 & 2,7 & 2,9 & 8,7 & 17,0 & 10,6 & 5,0 & 7,2 & 7,9 \\
\hline & 3 & 8,3 & 5,3 & 6,3 & 4,0 & 2,9 & 2,5 & 8,4 & 17,9 & 12,5 & 7,1 & 7,4 & 7,9 \\
\hline & 4 & 8,0 & 5,4 & 5,8 & 4,1 & 2,8 & 2,6 & 9,9 & 13,8 & 9,4 & 5,2 & 8,7 & 6,9 \\
\hline & 5 & 8,1 & 5,1 & 6,2 & 4,0 & 2,7 & 2,9 & 9,5 & 15,6 & 10,8 & 6,7 & 8,5 & 9,7 \\
\hline & 6 & 7,8 & 5,5 & 6,6 & 4,2 & 2,7 & 3,3 & 9,8 & 12,6 & 9,5 & 5,1 & 8,5 & 6,9 \\
\hline
\end{tabular}




\begin{tabular}{|c|c|c|c|c|c|c|c|c|c|c|c|c|c|}
\hline & & \multicolumn{6}{|c|}{ Mexilhões $P$. perna } & \multicolumn{6}{|c|}{ Ostras $C$. brasiliana } \\
\hline & & \multicolumn{3}{|c|}{ Comp. (cm) } & \multicolumn{3}{|c|}{ Alt. (cm) } & \multicolumn{3}{|c|}{ Comp. (cm) } & \multicolumn{3}{|c|}{ Altura (cm) } \\
\hline & & Coc & Pal & Ita & Coc & Pal & Ita & Can & San & Ber & Can & San & Ber \\
\hline & 7 & 7,6 & 5,3 & 6,5 & 4,1 & 2,7 & 3,1 & 8,6 & 13,9 & 10,7 & 5,5 & 8,8 & 7,2 \\
\hline & 8 & 8,0 & 5,1 & 7,3 & 3,9 & 2,8 & 3,3 & 8,2 & 15,5 & 10,9 & 6,7 & 7,1 & 9,3 \\
\hline & 9 & 7,7 & 5,2 & 5,9 & 4,0 & 2,5 & 2,7 & 8,1 & 15,7 & 9,5 & 5,4 & 6,9 & 5,8 \\
\hline & 10 & 7,6 & 5,5 & 6,1 & 4,0 & 2,7 & 2,7 & 8,5 & 13,7 & 9,6 & 5,1 & 8,2 & 9,7 \\
\hline & 11 & 7,8 & 5,5 & 6,5 & 4,0 & 3,1 & 2,8 & 10,0 & 13,9 & 10,9 & 6,1 & 7,7 & 8,3 \\
\hline & 12 & 7,4 & 5,5 & 6,3 & 4,0 & 2,7 & 2,7 & 9,6 & 14,4 & 9,9 & 5,6 & 9,1 & 7,0 \\
\hline & 13 & 7,6 & 4,9 & 6,7 & 3,8 & 2,5 & 2,8 & 7,9 & 14,6 & 9,6 & 5,8 & 8,5 & 8,1 \\
\hline & 14 & 7,3 & 5,5 & 6,4 & 4,1 & 2,8 & 2,9 & 10,5 & 13,9 & 10,7 & 6,2 & 7,7 & 7,8 \\
\hline & 15 & 7,4 & 5,3 & 5,9 & 3,9 & 2,7 & 2,8 & 8,5 & 11,5 & 9,9 & 5,5 & 9,5 & 9,9 \\
\hline & 16 & 7,6 & 5,4 & 5,9 & 3,8 & 2,6 & 2,8 & 9,9 & 16,5 & 10,6 & 7,2 & 9,1 & 7,1 \\
\hline & 17 & 7,7 & 5,0 & 5,7 & 4,1 & 2,5 & 2,8 & 8,5 & 16,2 & 8,9 & 4,5 & 7,1 & 6,9 \\
\hline \multirow[t]{17}{*}{ Out/17 } & 1 & 8,1 & 6,9 & 7,2 & 4,2 & 3,3 & 3,3 & 9,0 & 10,6 & 11,9 & 5,6 & 6,5 & 9,2 \\
\hline & 2 & 9,0 & 6,6 & 7,0 & 4,2 & 3,1 & 2,9 & 9,0 & 12,8 & 10,2 & 5,0 & 6,6 & 9,0 \\
\hline & 3 & 8,5 & 7,0 & 6,9 & 4,3 & 3,1 & 3,0 & 9,7 & 13,2 & 11,9 & 4,9 & 8,4 & 5,0 \\
\hline & 4 & 8,2 & 7,3 & 7,3 & 4,3 & 3,1 & 3,0 & 10,1 & 14,9 & 10,6 & 6,5 & 7,5 & 8,0 \\
\hline & 5 & 8,5 & 7,6 & 7,1 & 4,0 & 3,4 & 3,1 & 9,6 & 12,6 & 11,8 & 6,0 & 6,4 & 9,6 \\
\hline & 6 & 8,5 & 6,8 & 7,6 & 4,8 & 3,4 & 3,3 & 9,7 & 10,6 & 13,7 & 4,9 & 7,5 & 9,0 \\
\hline & 7 & 8,4 & 7,1 & 6,9 & 4,0 & 3,2 & 3,1 & 8,1 & 12,8 & 11,7 & 5,0 & 6,5 & 10,0 \\
\hline & 8 & 9,3 & 7,2 & 7,5 & 4,1 & 3,2 & 3,3 & 8,3 & 11,5 & 10,7 & 6,0 & 6,5 & 6,4 \\
\hline & 9 & 9,1 & 6,9 & 7,6 & 4,5 & 3,5 & 3,2 & 8,4 & 11,7 & 11,8 & 4,8 & 8,7 & 7,5 \\
\hline & 10 & 9,0 & 7,1 & 7,5 & 4,3 & 3,1 & 3,2 & 9,8 & 11,0 & 11,4 & 4,6 & 5,3 & 8,6 \\
\hline & 11 & 9,4 & 7,2 & 7,3 & 4,4 & 3,1 & 3,4 & 8,3 & 12,4 & 8,4 & 6,3 & 6,6 & 5,8 \\
\hline & 12 & 8,2 & 6,8 & 7,7 & 4,2 & 3,1 & 3,0 & 8,9 & 10,7 & 10,0 & 5,9 & 8,1 & 7,0 \\
\hline & 13 & 8,6 & 7,3 & 7,4 & 4,3 & 3,2 & 3,1 & 8,3 & 12,7 & 11,4 & 5,3 & 8,4 & 6,8 \\
\hline & 14 & 8,2 & 7,0 & 6,7 & 4,0 & 3,3 & 2,9 & 9,2 & 13,8 & 9,6 & 4,4 & 7,6 & 9,7 \\
\hline & 15 & 9,2 & 6,9 & 7,3 & 4,4 & 3,0 & 2,9 & 8,4 & 10,5 & 9,0 & 5,4 & 7,3 & 6,3 \\
\hline & 16 & 8,4 & 7,1 & 7,7 & 4,1 & 3,2 & 3,6 & 8,2 & 9,6 & 10,9 & 4,3 & 7,8 & 5,8 \\
\hline & 17 & 8,0 & 6,9 & 7,6 & 4,1 & 3,9 & 3,2 & 8,3 & 9,8 & 9,0 & 5,9 & 6,5 & 6,5 \\
\hline média & & & 7,1 & & & 3,4 & & & 11,0 & & & 7,0 & \\
\hline mínimo & & & 4,9 & & & 2,5 & & & 7,9 & & & 4,3 & \\
\hline máximo & & & 9,4 & & & 4,8 & & & 17,9 & & & 10,0 & \\
\hline
\end{tabular}




\section{APÊNDICE B}

Respostas bioquímicas de EROD, DBF, GST, GSH, LPO, DNA e ChE medidas em cada amostra de brânquia de mexilhões $P$. perna e ostras $C$. brasiliana. 


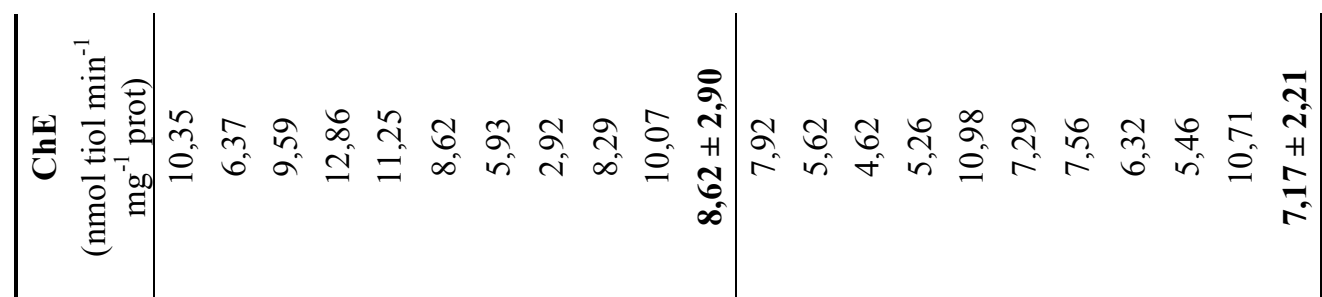

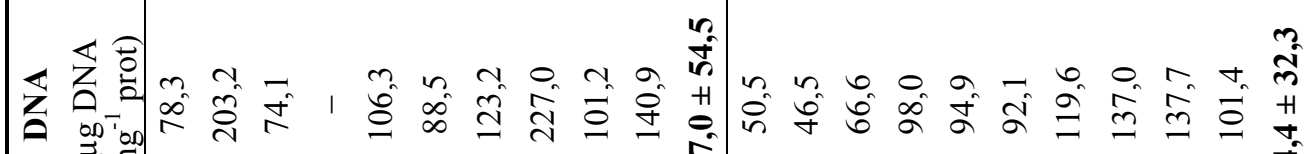

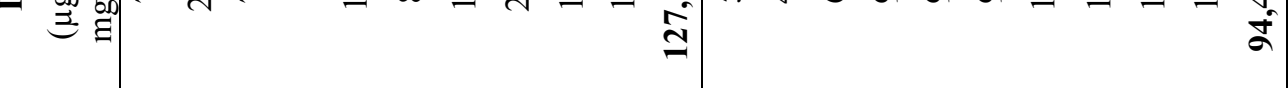
莺

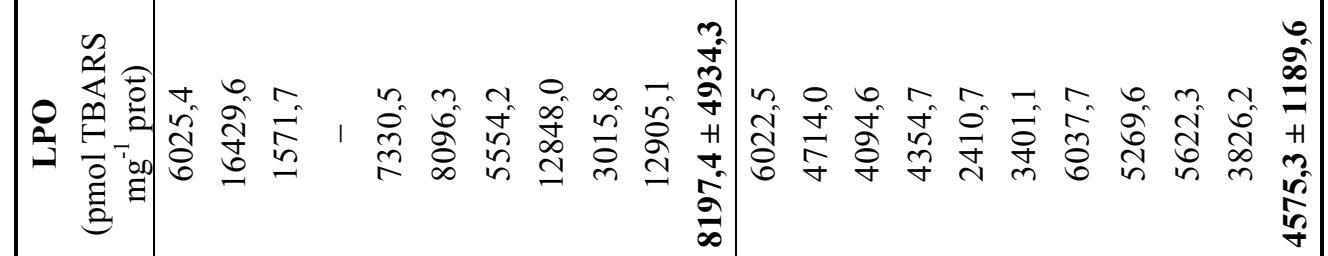

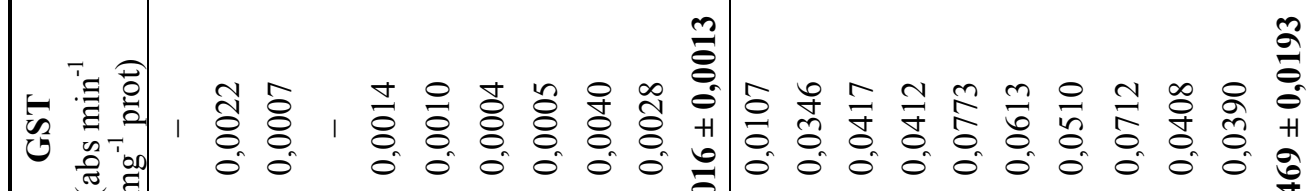

จิ

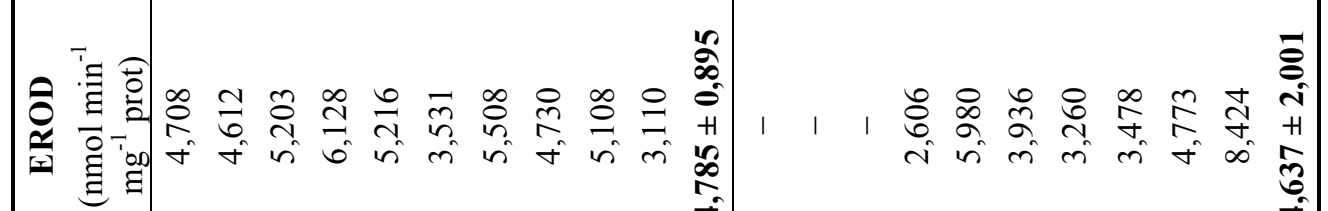

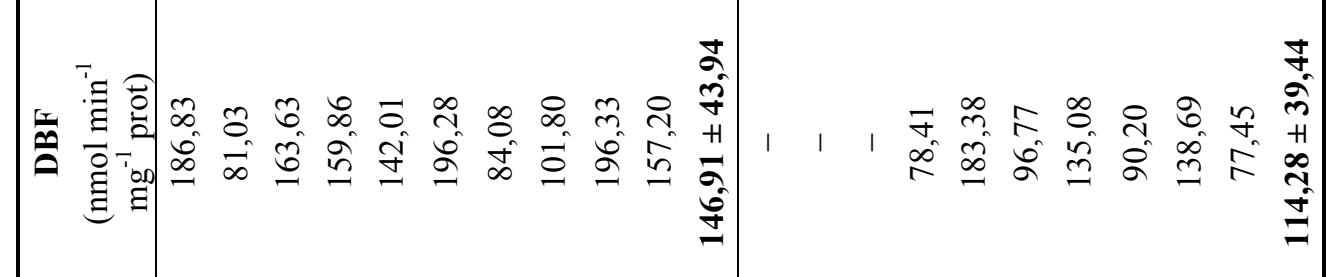




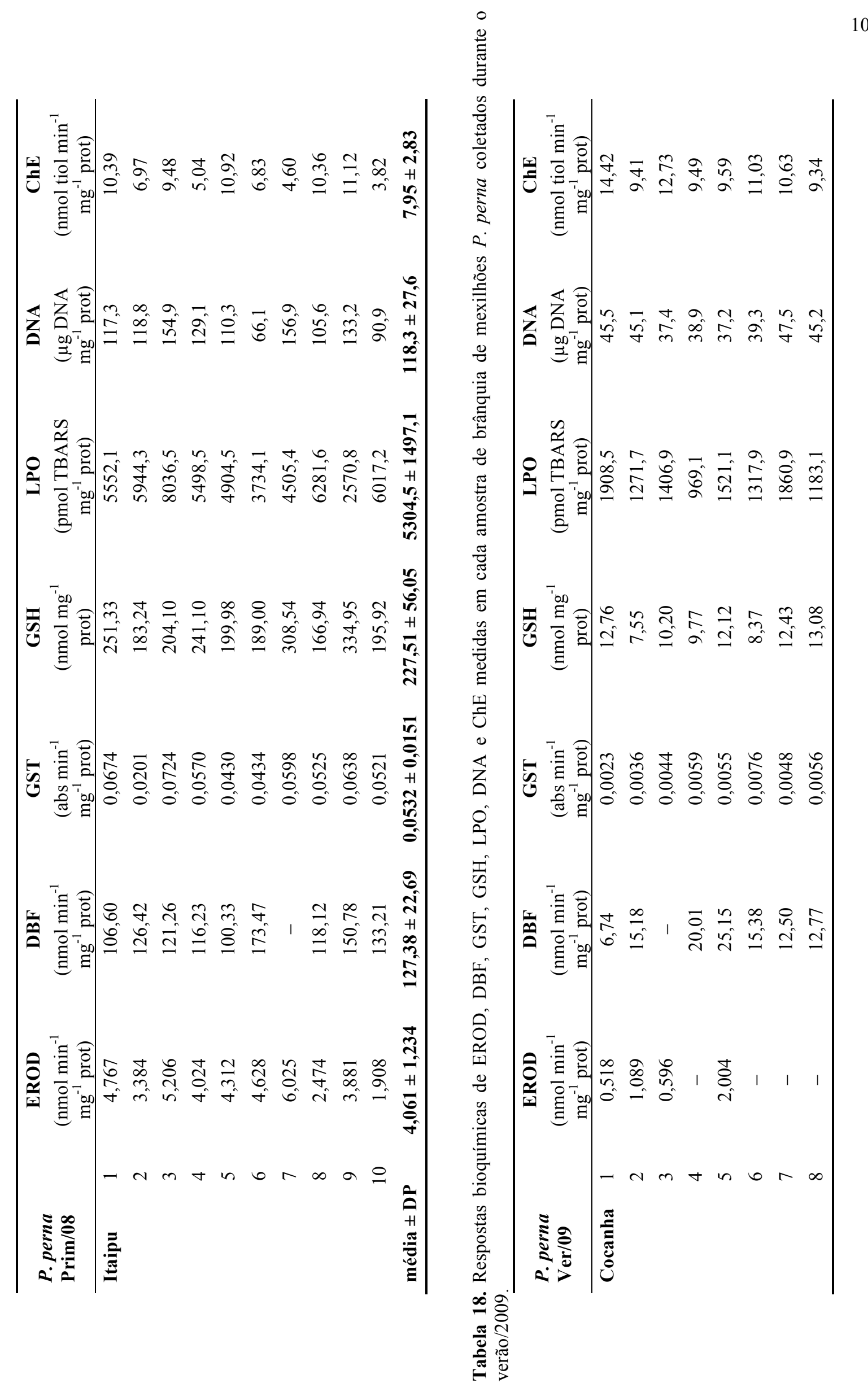




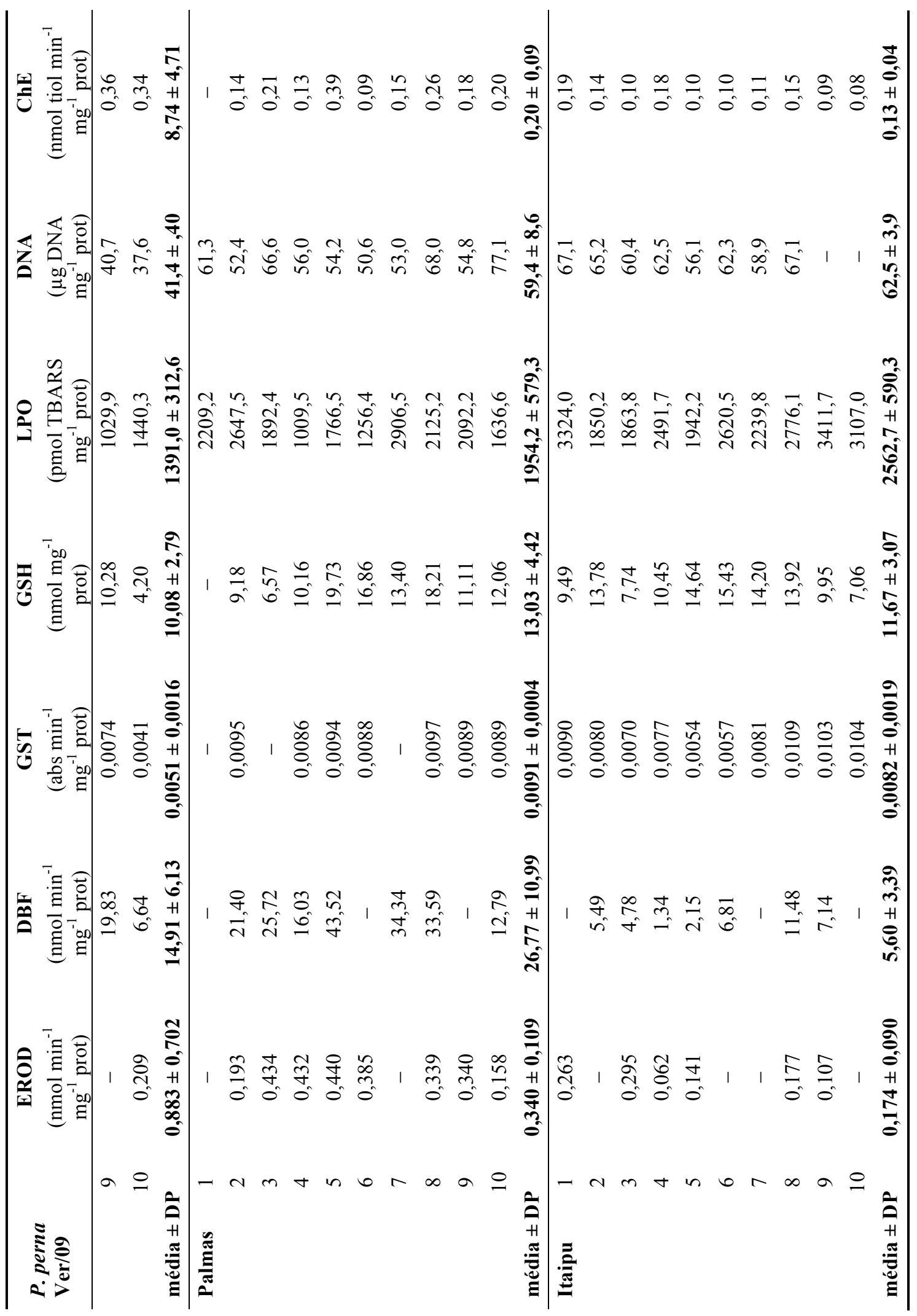




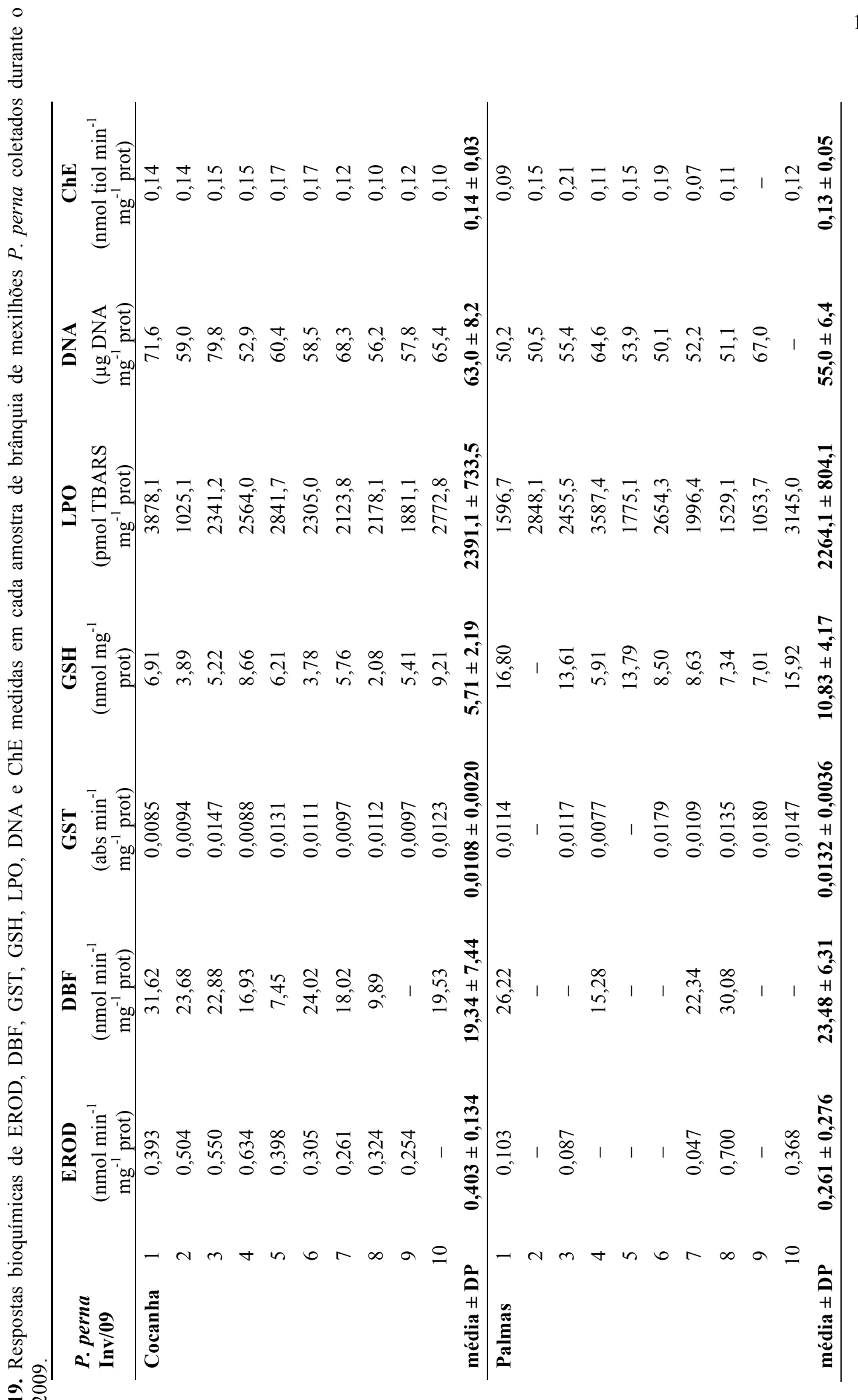




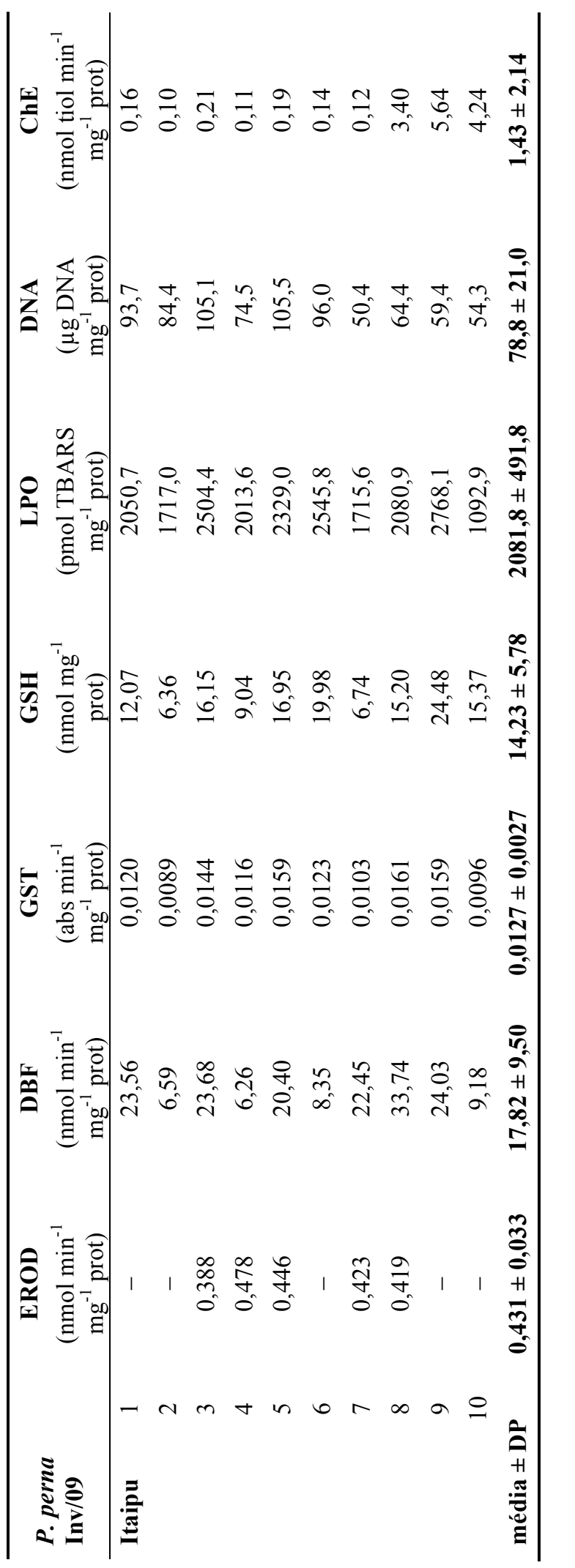

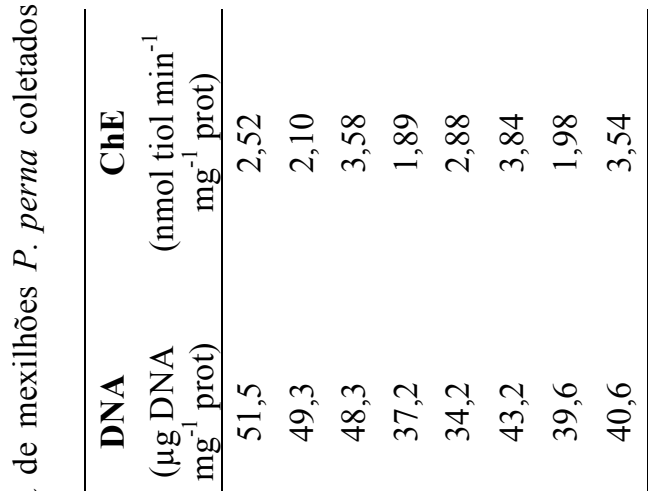
节

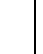

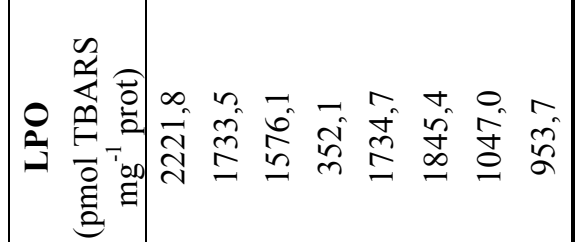

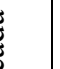

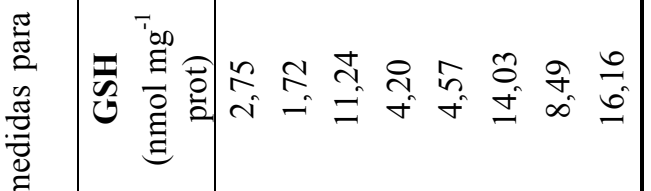
ป 


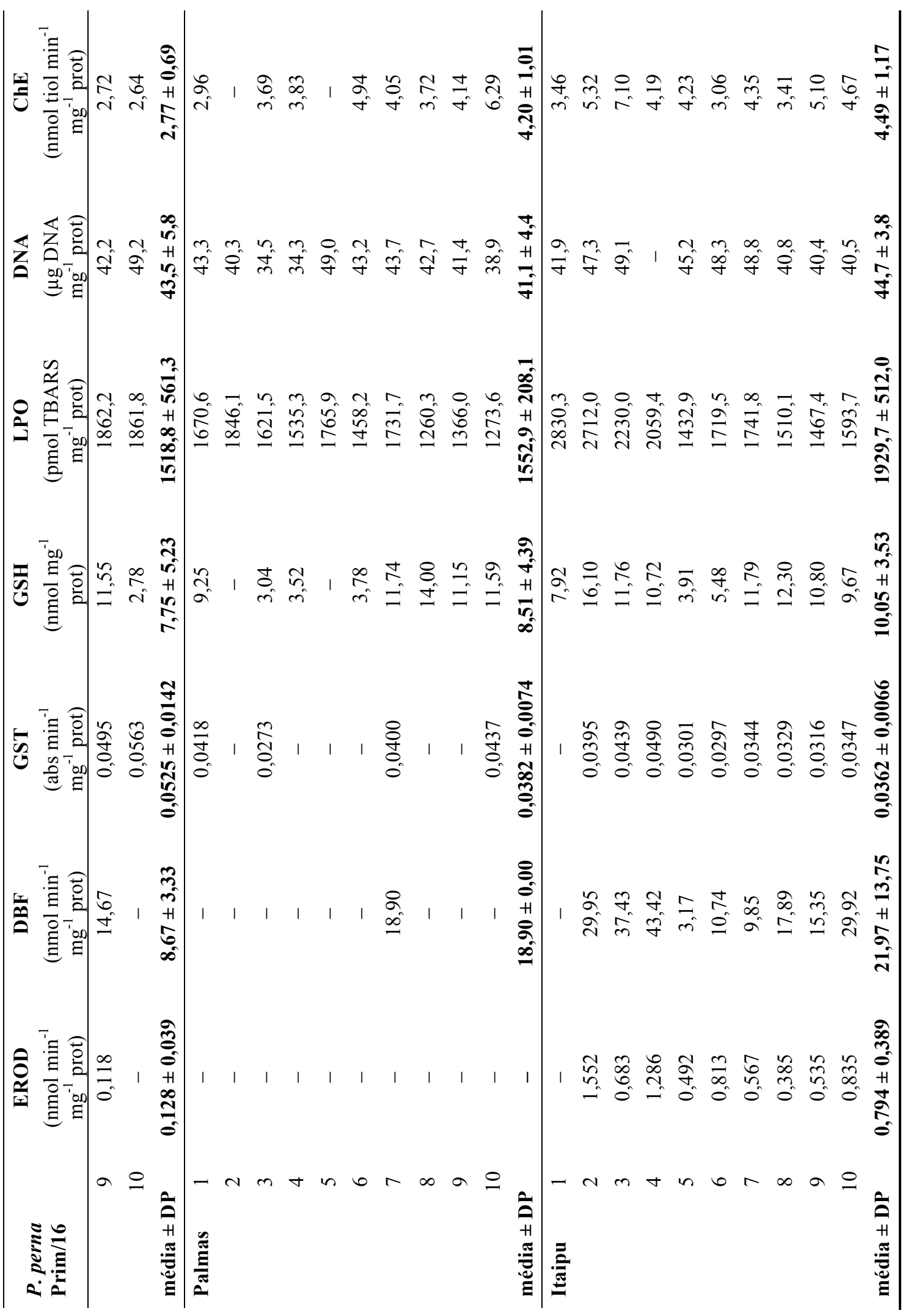




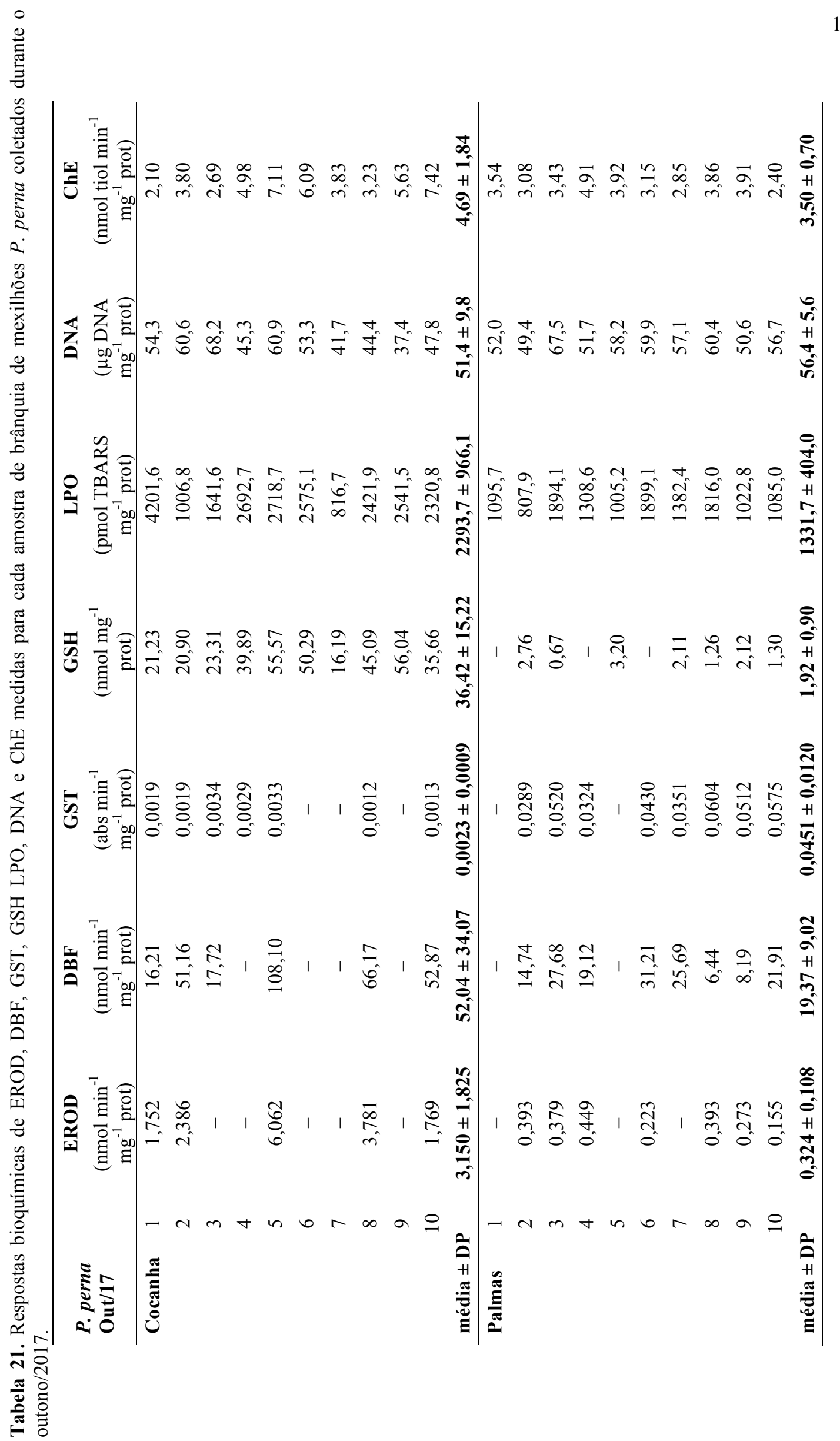




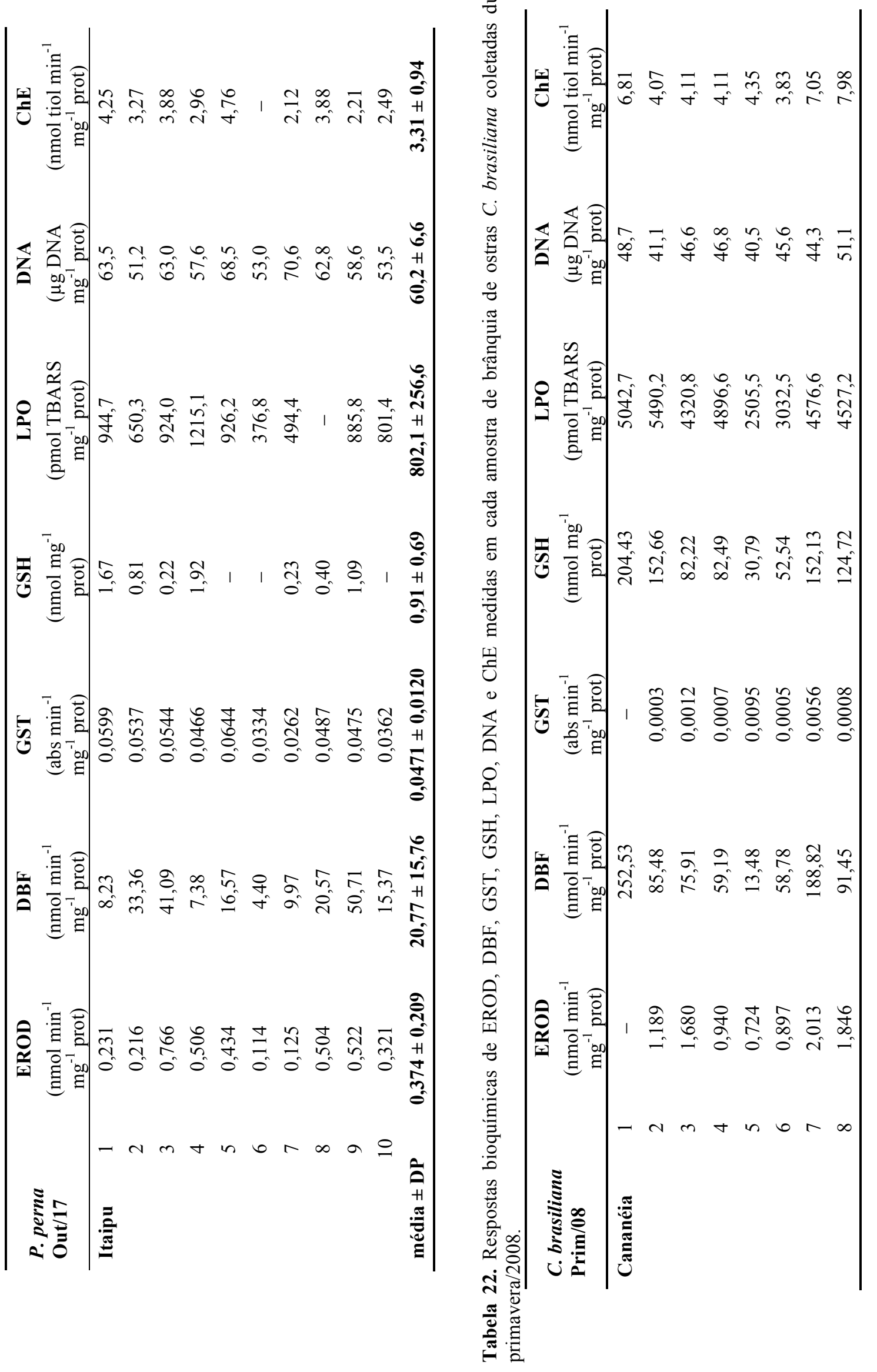




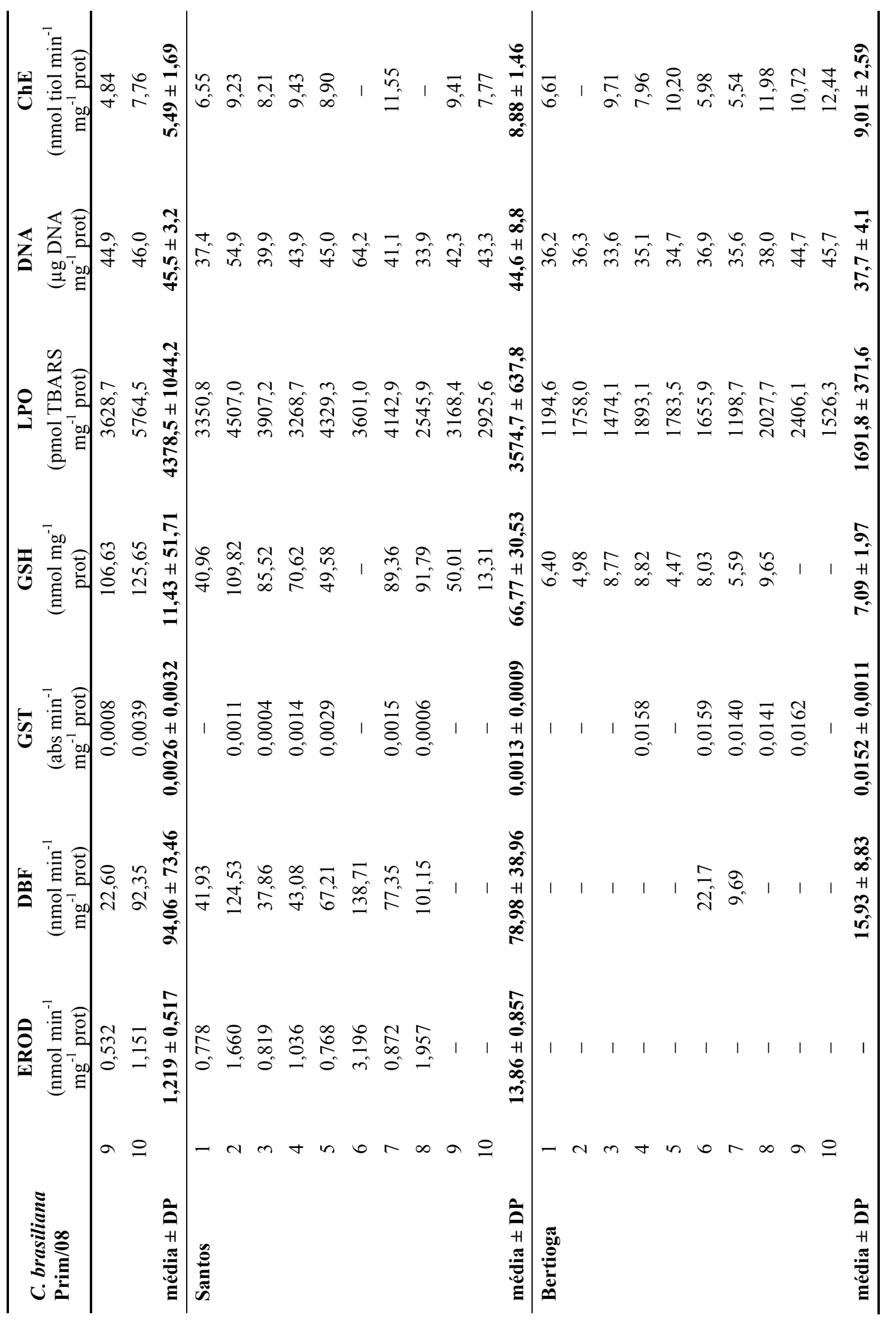




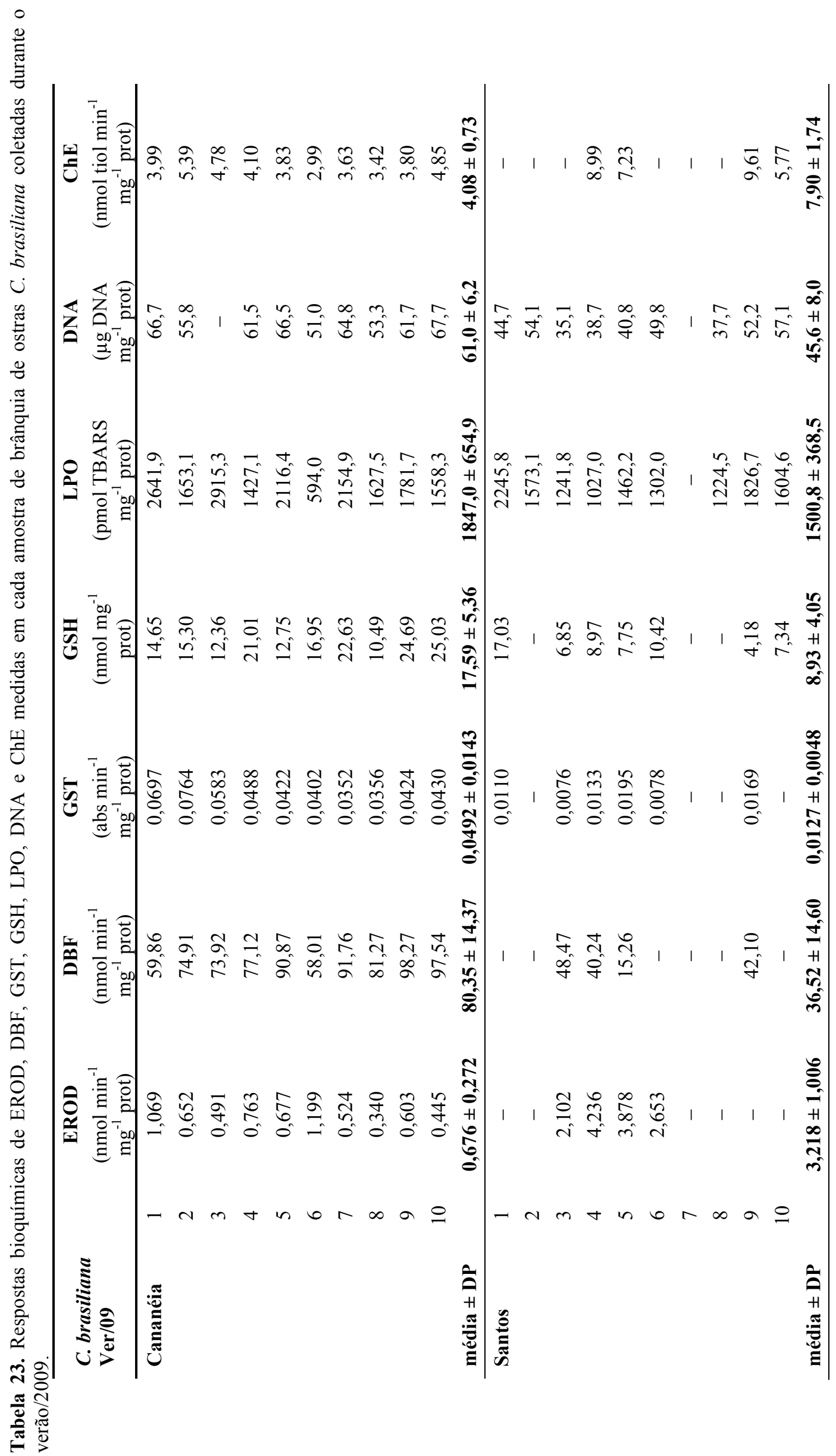




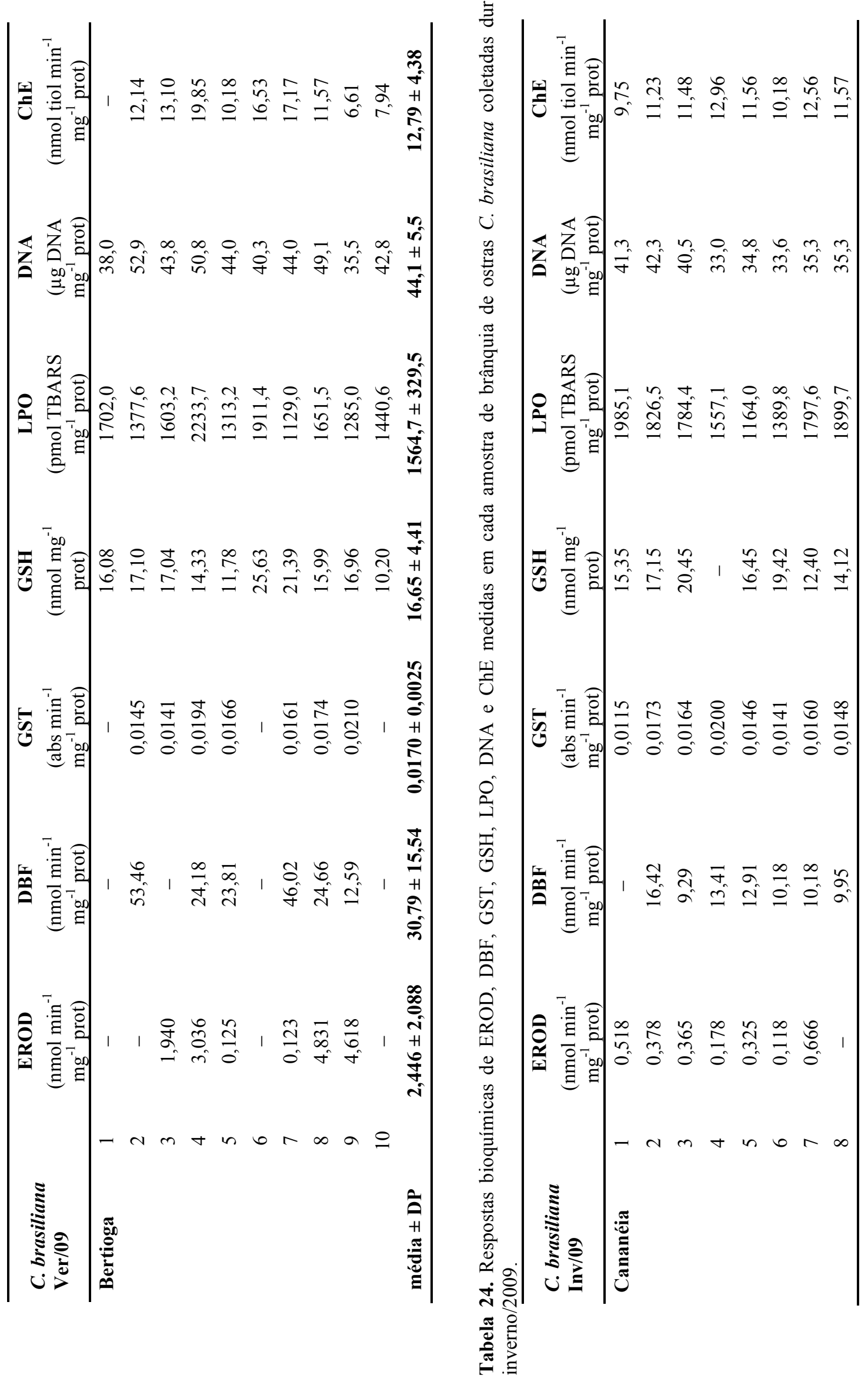




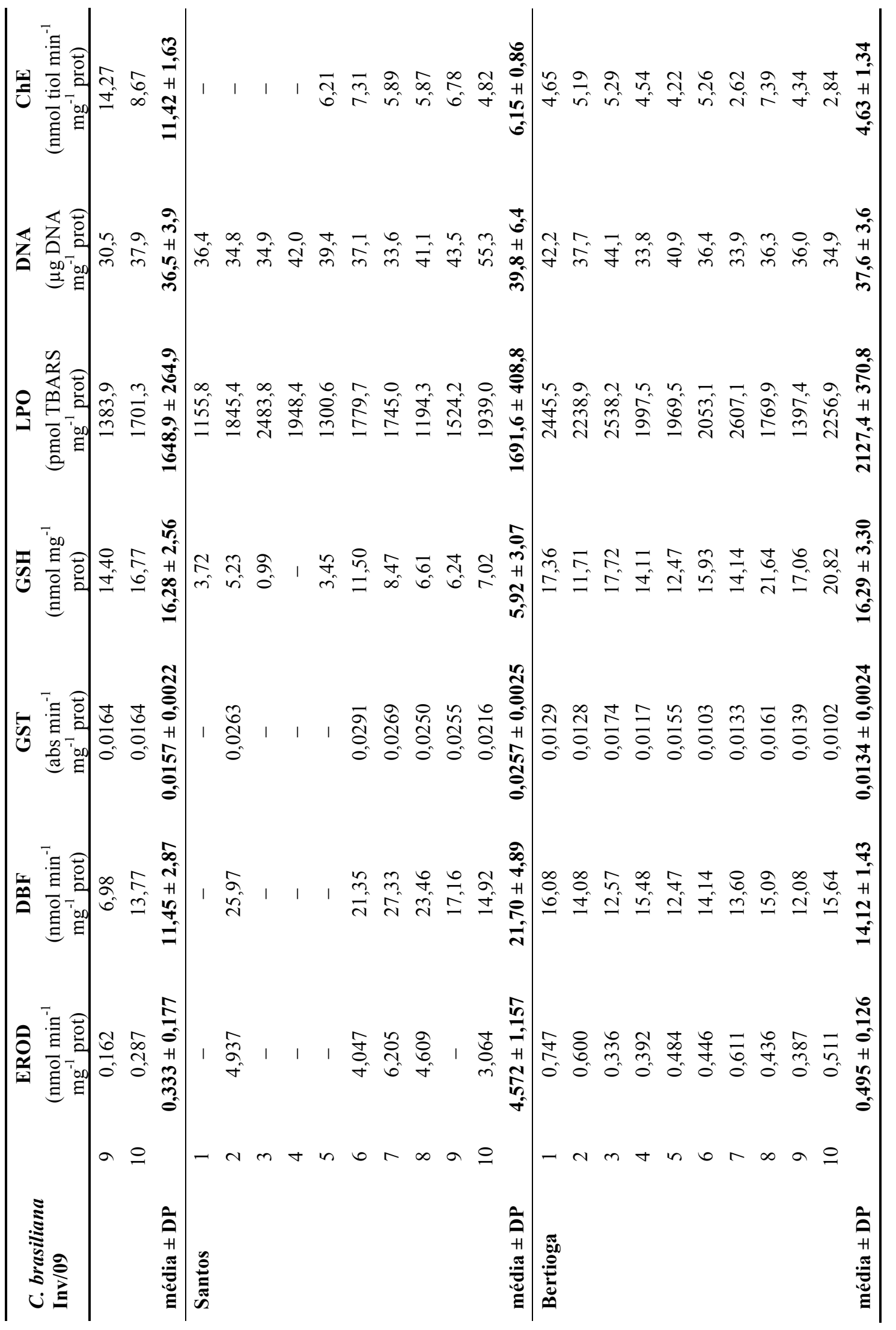




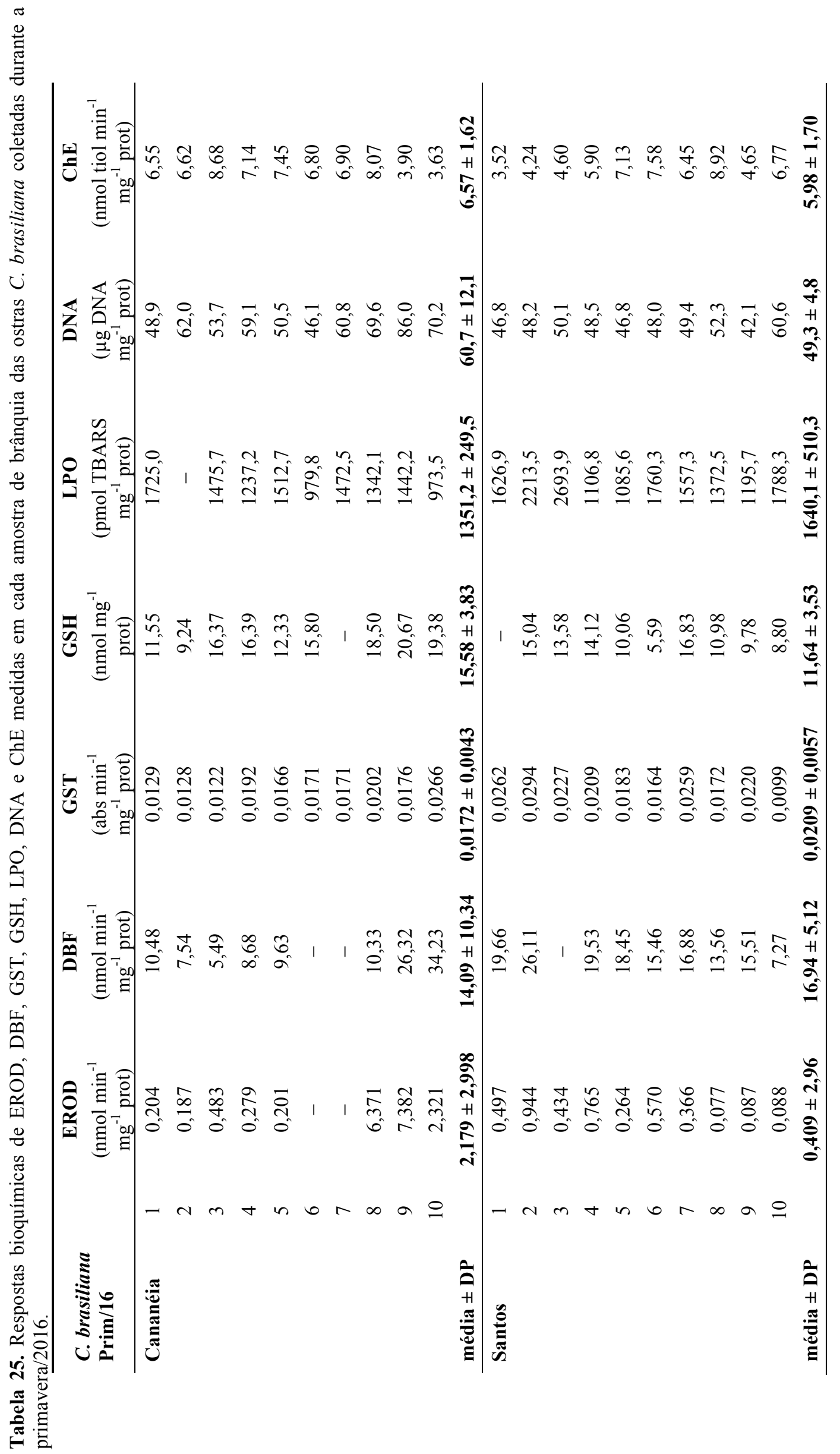




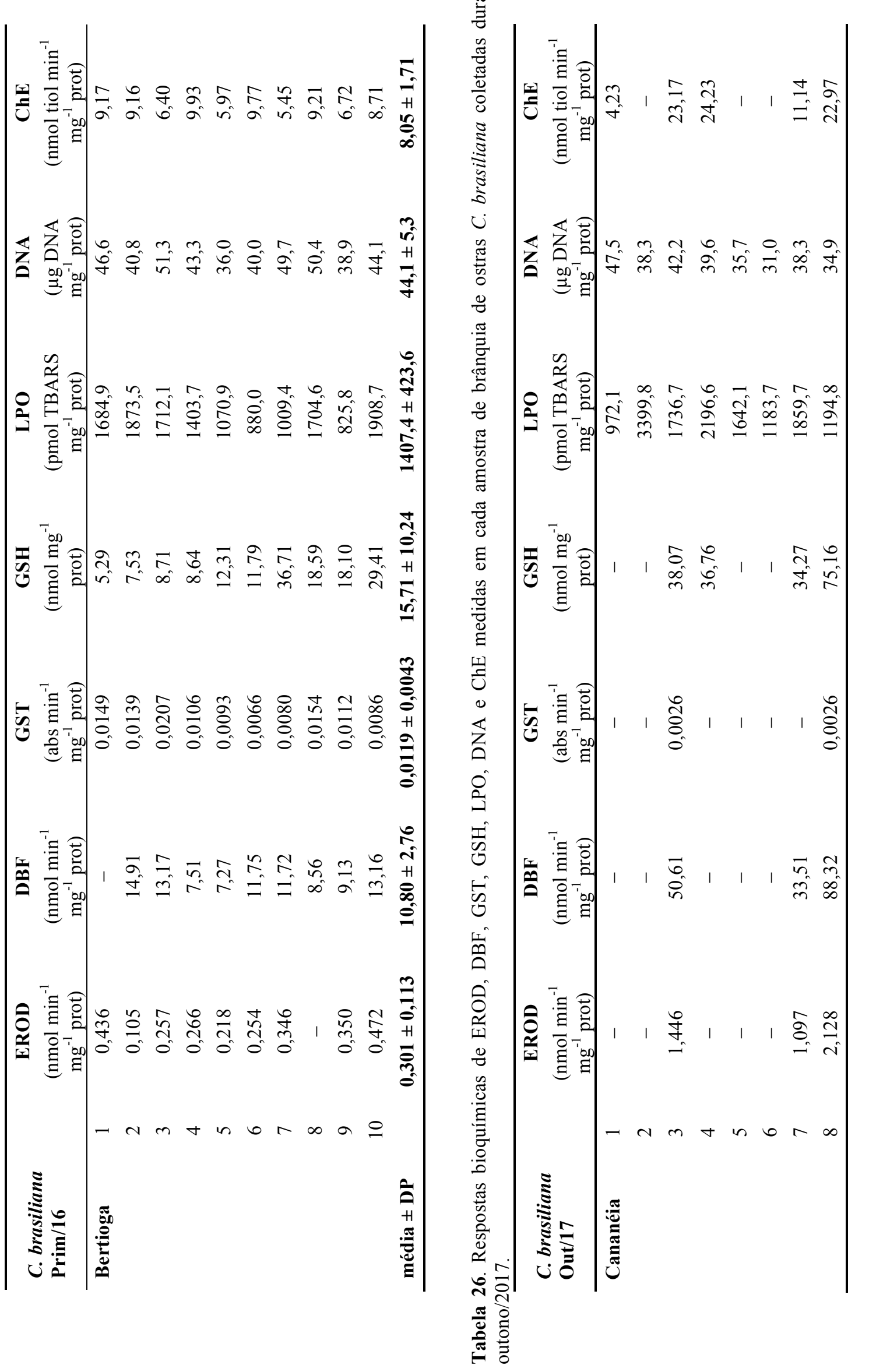




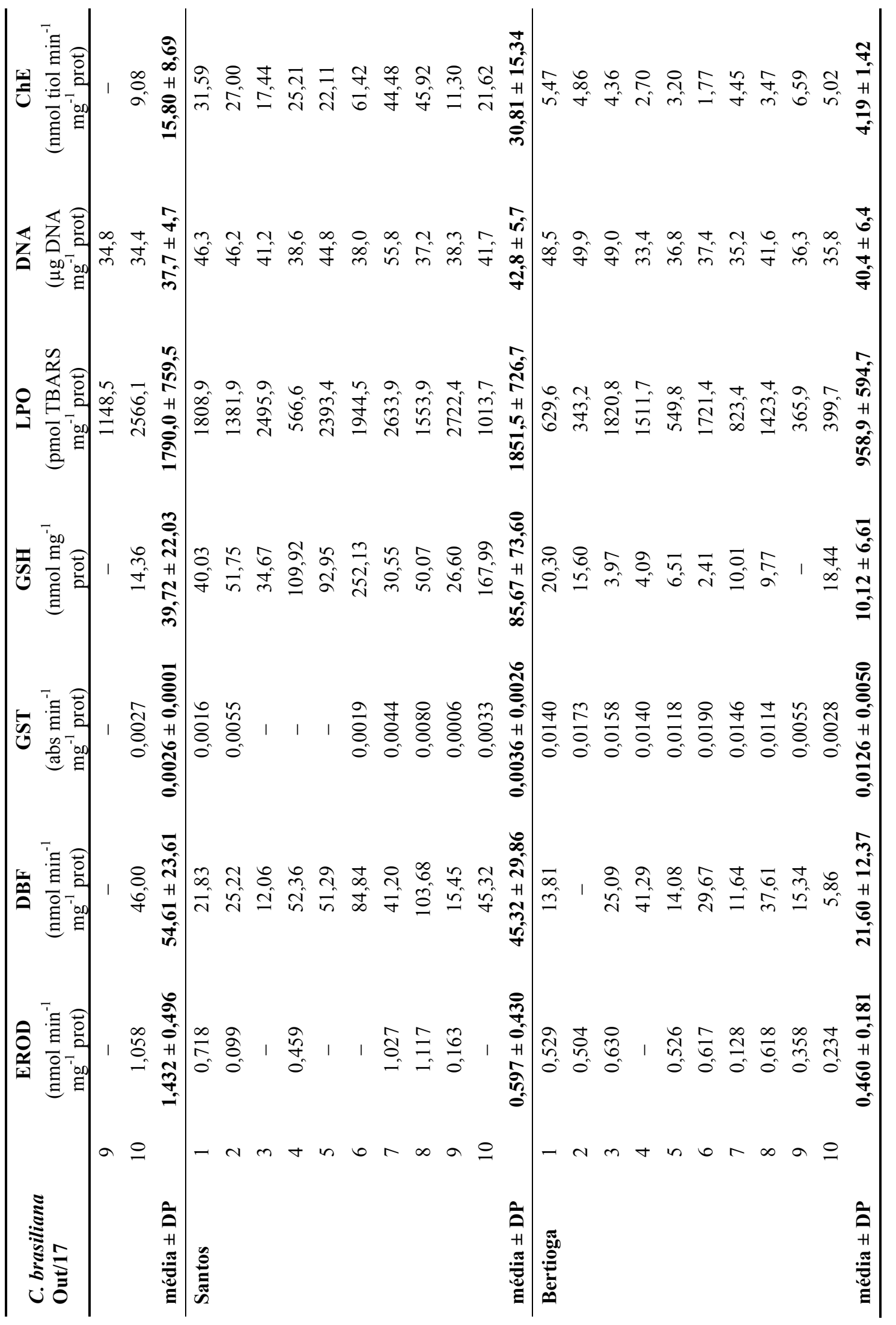




\section{APÊNDICE C}

Tempos de retenção do corante vermelho neutro observados para cada mexilhão $P$. perna e cada ostra C. brasiliana analisados. 
Tabela 27. Tempos de retenção do corante vermelho neutro (minutos) observados para cada mexilhão $P$. perna e cada ostra C. brasiliana analisados.

\begin{tabular}{|c|c|c|c|c|c|c|c|}
\hline & & \multicolumn{3}{|c|}{ Mexilhões $P$. perna } & \multicolumn{3}{|c|}{ Ostras $C$. brasiliana } \\
\hline & & Coc & Pal & Ita & Can & San & Ber \\
\hline \multirow[t]{17}{*}{ Prim/16 } & 1 & 45 & 60 & 45 & 45 & 60 & 60 \\
\hline & 2 & 60 & 45 & 45 & 45 & 45 & 60 \\
\hline & 3 & 45 & 45 & 45 & 45 & 45 & 60 \\
\hline & 4 & 45 & 15 & 60 & 45 & 45 & 45 \\
\hline & 5 & 60 & 60 & 60 & 60 & 30 & 60 \\
\hline & 6 & 45 & 30 & 45 & 45 & 30 & 60 \\
\hline & 7 & 45 & 30 & 45 & 30 & 30 & 15 \\
\hline & 8 & 45 & 30 & 45 & 30 & 30 & 45 \\
\hline & 9 & 30 & 60 & 30 & 45 & 30 & 45 \\
\hline & 10 & 30 & 60 & 45 & 30 & 15 & 30 \\
\hline & 11 & 30 & 45 & 45 & 30 & 15 & 30 \\
\hline & 12 & 45 & 60 & 45 & 45 & 45 & 15 \\
\hline & 13 & 30 & 60 & 45 & 30 & 15 & 15 \\
\hline & 14 & 45 & 30 & 30 & 30 & 45 & 15 \\
\hline & 15 & 30 & 15 & - & 30 & 15 & 30 \\
\hline & 16 & 30 & 60 & - & 30 & 45 & 15 \\
\hline & 17 & 45 & - & - & 30 & - & 45 \\
\hline \multicolumn{2}{|c|}{ média \pm DP } & $41,47 \pm 9,96$ & $44,06 \pm 16,85$ & $45,00 \pm 8,32$ & $37,94 \pm 9,36$ & $33,75 \pm 13,96$ & $37,94 \pm 18,46$ \\
\hline \multirow[t]{17}{*}{ Out/17 } & 1 & 60 & 60 & 45 & 60 & 15 & 45 \\
\hline & 2 & 30 & 60 & 60 & 60 & 30 & 45 \\
\hline & 3 & 60 & 60 & 45 & 60 & 30 & 45 \\
\hline & 4 & 90 & 60 & 45 & 60 & 30 & 60 \\
\hline & 5 & 30 & 60 & 45 & 60 & 15 & 60 \\
\hline & 6 & 90 & 60 & 60 & 60 & 15 & 60 \\
\hline & 7 & 90 & 60 & 60 & 60 & 30 & 45 \\
\hline & 8 & 90 & 60 & 45 & 60 & 30 & 45 \\
\hline & 9 & 90 & 60 & 45 & 60 & 30 & 30 \\
\hline & 10 & 120 & 60 & 60 & 45 & 30 & 45 \\
\hline & 11 & 60 & 60 & 45 & 60 & 30 & 30 \\
\hline & 12 & 90 & 60 & 60 & 45 & 15 & 30 \\
\hline & 13 & 120 & 60 & 30 & 45 & 30 & 45 \\
\hline & 14 & 90 & 60 & 45 & 60 & 30 & 30 \\
\hline & 15 & 60 & 60 & 45 & 60 & 15 & 30 \\
\hline & 16 & 90 & 45 & 45 & 60 & 15 & 45 \\
\hline & 17 & 120 & 45 & 45 & 60 & 15 & 45 \\
\hline \multicolumn{2}{|c|}{ média \pm DP } & $81,18 \pm 27,59$ & $58,23 \pm 4,98$ & $48,53 \pm 8,43$ & $\mathbf{5 7 , 3 5} \pm \mathbf{5 , 8 9}$ & $23,82 \pm 7,61$ & $43,24 \pm 10,45$ \\
\hline
\end{tabular}




\section{APÊNDICE D}

Matrizes de dados utilizadas para a realização das análises de componentes principais (PCA) e resultados das PCAs. 
Tabela 32. Autovalores (Eigenvalues) para cada componente (Eigenvectors) e loadings para cada variável, gerados pela PCA a partir dos dados referentes aos mexilhões $P$. perna coletados durante a primavera/2008, o verão/2009 e o inverno/2009. Valores destacados quando $\mid$ loadings $\mid \geq 0,50$.

\begin{tabular}{|c|c|c|c|}
\hline \multirow{2}{*}{$\begin{array}{l}P . \text { perna } \\
2008 / 09\end{array}$} & \multicolumn{3}{|c|}{ Eigenvectors } \\
\hline & 1 & 2 & 3 \\
\hline Eigenvalue & 6,239 & 5,658 & 2,577 \\
\hline Variância (\%) & 36,699 & 33,283 & 15,160 \\
\hline Var. cumulativa (\%) & 36,699 & 69,982 & 85,142 \\
\hline EROD & 0,982 & $-0,005$ & 0,016 \\
\hline $\mathrm{DBF}$ & 0,957 & 0,071 & 0,050 \\
\hline GST & 0,579 & $-0,668$ & 0,219 \\
\hline GSH & 0,909 & $-0,366$ & 0,076 \\
\hline LPO & 0,905 & 0,094 & 0,028 \\
\hline DNA & 0,854 & $-0,198$ & 0,283 \\
\hline $\mathrm{ChE}$ & $\mathbf{0 , 8 3 0}$ & 0,156 & $-0,324$ \\
\hline NRRT & $-0,054$ & 0,371 & $-0,862$ \\
\hline $\mathrm{Cd}$ & 0,058 & 0,978 & $-0,002$ \\
\hline $\mathrm{Hg}$ & $-0,311$ & 0,777 & 0,479 \\
\hline $\mathrm{Pb}$ & $-0,223$ & 0,013 & $-0,735$ \\
\hline As & 0,207 & 0,885 & $-0,164$ \\
\hline $\mathrm{Cr}$ & 0,237 & 0,957 & $-0,075$ \\
\hline $\mathrm{Fe}$ & 0,226 & 0,967 & 0,046 \\
\hline $\mathrm{Se}$ & $-0,060$ & 0,762 & 0,609 \\
\hline Co & $-0,669$ & $-0,272$ & $-0,075$ \\
\hline $\mathrm{Zn}$ & $-0,454$ & $-0,124$ & 0,641 \\
\hline
\end{tabular}

Tabela 33. Scores para cada ponto de coleta, gerados pela PCA a partir dos dados referentes aos mexilhões $P$. perna coletados durante a primavera/2008, o verão/2009 e o inverno/2009.

\begin{tabular}{lccc}
\hline \multirow{2}{*}{\begin{tabular}{l} 
2008/09 \\
\cline { 2 - 4 } P08-Coc
\end{tabular}} & \multicolumn{3}{c}{ Eigenvectors } \\
\cline { 2 - 4 } P08-Pal & 3,580 & 3,745 & $-0,413$ \\
P08-Ita & 2,479 & $-2,214$ & 0,487 \\
V09-Coc & 3,653 & $-2,731$ & 0,176 \\
V09-Pal & $-0,508$ & 1,744 & $-2,066$ \\
V09-Ita & $-2,053$ & $-0,917$ & $-1,297$ \\
I09-Coc & $-2,255$ & $-1,577$ & $-1,950$ \\
I09-Pal & $-1,454$ & 3,367 & 1,351 \\
I09-Ita & $-1,653$ & $-0,993$ & 0,932 \\
\hline
\end{tabular}

Tabela 34. Autovalores (Eigenvalues) para cada componente (Eigenvectors) e loadings para cada variável gerados pela PCA a partir dos dados referentes às ostras $C$. brasiliana coletadas durante a primavera/2008, o verão/2009 e o inverno/2009. Valores destacados quando $\mid$ loadings $\mid \geq 0,50$.

\begin{tabular}{|c|c|c|c|}
\hline \multirow{2}{*}{$\begin{array}{l}\text { C. brasiliana } \\
2008 / 09\end{array}$} & \multicolumn{3}{|c|}{ Eigenvectors } \\
\hline & 1 & 2 & 3 \\
\hline Eigenvalue & 6,907 & 3,514 & 2,677 \\
\hline Variância (\%) & 40,631 & 20,668 & 15,750 \\
\hline Var. cumulativa $(\%)$ & 40,631 & 61,299 & 77,049 \\
\hline EROD & $-0,635$ & $-0,197$ & $-0,365$ \\
\hline DBF & 0,147 & $-0,940$ & $-0,102$ \\
\hline GST & $-0,297$ & 0,048 & 0,815 \\
\hline GSH & 0,672 & $-0,562$ & $-0,383$ \\
\hline LPO & 0,474 & $-0,562$ & $-0,441$ \\
\hline DNA & 0,120 & $-0,750$ & 0,397 \\
\hline ChE & 0,095 & $\mathbf{0 , 5 9 4}$ & $-0,431$ \\
\hline NRRT & $\mathbf{0 , 5 9 7}$ & $-0,383$ & 0,366 \\
\hline $\mathrm{Cd}$ & $-0,639$ & $-0,564$ & $-0,131$ \\
\hline $\mathrm{Hg}$ & $-0,854$ & $-0,178$ & $-0,452$ \\
\hline $\mathrm{Pb}$ & $-0,953$ & 0,004 & 0,100 \\
\hline As & 0,063 & $-0,404$ & 0,648 \\
\hline $\mathrm{Cr}$ & $-0,623$ & 0,375 & 0,012 \\
\hline $\mathrm{Fe}$ & $-0,706$ & 0,077 & 0,596 \\
\hline $\mathrm{Se}$ & $-0,911$ & $-0,304$ & $-0,159$ \\
\hline $\mathrm{Co}$ & $-0,918$ & $-0,335$ & $-0,021$ \\
\hline $\mathrm{Zn}$ & $-0,853$ & $-0,179$ & $-0,137$ \\
\hline
\end{tabular}

Tabela 35. Scores para cada ponto de coleta, gerados pela PCA a partir dos dados referentes às ostras C. brasiliana coletadas durante a primavera/2008, o verão/2009 e o inverno/2009.

\begin{tabular}{lccc}
\hline \multirow{2}{*}{\begin{tabular}{l} 
2008/09 brasiliana \\
\cline { 2 - 4 }
\end{tabular}} & \multicolumn{3}{c}{ Eigenvectors } \\
\hline P08-Can & 2,273 & $-2,895$ & $-0,524$ \\
P08-San & 1,801 & $-1,176$ & $-2,851$ \\
P08-Ber & 0,553 & 1,815 & 0,699 \\
V09-Can & 0,578 & $-2,187$ & 3,335 \\
V09-San & $-4,086$ & $-1,105$ & $-0,590$ \\
V09-Ber & 2,266 & 1,724 & $-0,593$ \\
I09-Can & 0,708 & 1,870 & 0,569 \\
I09-San & $-4,830$ & 0,401 & $-0,462$ \\
I09-Ber & 0,739 & 1,554 & 0,418 \\
\hline
\end{tabular}


Tabela 36. Autovalores (Eigenvalues) para cada componente (Eigenvectors) e loadings para cada variável, gerados pela PCA a partir dos dados referentes aos mexilhões $P$. perna coletados durante a primavera/2016 e o outono/2017. Valores destacados quando $\mid$ loadings $\mid \geq 0,50$.

\begin{tabular}{|c|c|c|c|}
\hline \multirow{2}{*}{$\begin{array}{l}\text { P. perna } \\
2016 / 17\end{array}$} & \multicolumn{3}{|c|}{ Eigenvectors } \\
\hline & 1 & 2 & 3 \\
\hline Eigenvalue & 8,295 & 4,747 & 2,662 \\
\hline Variância (\%) & 48,793 & 27,926 & 15,657 \\
\hline Var. cumulativa (\%) & 48,793 & 76,719 & 92,376 \\
\hline EROD & $-0,933$ & $-0,114$ & $-0,103$ \\
\hline $\mathrm{DBF}$ & $-0,873$ & $-0,114$ & $-0,416$ \\
\hline GST & 0,896 & 0,408 & 0,118 \\
\hline GSH & $-0,594$ & $-0,789$ & 0,068 \\
\hline LPO & $-0,560$ & $-0,742$ & 0,200 \\
\hline DNA & $-0,278$ & 0,869 & $-0,267$ \\
\hline $\mathrm{ChE}$ & $-0,497$ & $-0,481$ & $-0,710$ \\
\hline NRRT & $-0,971$ & 0,166 & $-0,147$ \\
\hline $\mathrm{Cd}$ & $-0,608$ & $-0,019$ & 0,656 \\
\hline $\mathrm{Hg}$ & $-0,964$ & 0,002 & 0,187 \\
\hline $\mathrm{Pb}$ & 0,057 & $-0,716$ & $-0,640$ \\
\hline As & $-0,881$ & $-0,210$ & 0,170 \\
\hline $\mathrm{Cr}$ & $-0,548$ & 0,564 & $-0,519$ \\
\hline $\mathrm{Fe}$ & $-0,593$ & 0,603 & 0,328 \\
\hline $\mathrm{Se}$ & $-0,716$ & 0,107 & 0,611 \\
\hline $\mathrm{Co}$ & $-0,268$ & 0,870 & $-0,409$ \\
\hline $\mathrm{Zn}$ & $-0,781$ & 0,601 & $-0,026$ \\
\hline
\end{tabular}

Tabela 37. Scores para cada ponto de coleta, gerados pela PCA a partir dos dados referentes aos mexilhões $P$. perna coletados durante a primavera/2016 e o outono/2017.

\begin{tabular}{lccc}
\hline \multirow{2}{*}{ 2016/17 } & \multicolumn{3}{c}{ Eigenvectors } \\
\cline { 2 - 4 } & $\mathbf{1}$ & $\mathbf{2}$ & $\mathbf{3}$ \\
\hline P16-Coc & 1,654 & $-0,340$ & 2,944 \\
P16-Pal & 1,977 & $-2,010$ & $-0,550$ \\
P16-Ita & 1,225 & $-2,081$ & $-1,668$ \\
O17-Coc & $-5,661$ & $-0,921$ & 0,382 \\
O17-Pal & $-0,288$ & 2,882 & $-1,186$ \\
O17-Ita & 1,094 & 2,470 & 0,078 \\
\hline
\end{tabular}

Tabela 38. Autovalores (Eigenvalues) para cada componente (Eigenvectors) e loadings para cada variável, gerados pela PCA a partir dos dados referentes às ostras $C$. brasiliana coletadas durante a primavera/2016 e o outono/2017. Valores destacados quando $\mid$ loadings $\mid \geq 0,50$.

\begin{tabular}{lccc}
\hline \multirow{2}{*}{ C. brasiliana } & \multicolumn{3}{c}{ Eigenvectors } \\
\cline { 2 - 4 } Eigenvalue & $\mathbf{1}$ & $\mathbf{2}$ & $\mathbf{3}$ \\
Variância (\%) & 38,610 & 5,367 & 2,544 \\
Var. cumulativa (\%) & 38,883 & 70,455 & 85,420 \\
\hline \hline EROD & $\mathbf{0 , 8 4 6}$ & $-0,316$ & $-0,404$ \\
$\mathrm{DBF}$ & $\mathbf{0 , 9 0 7}$ & 0,242 & $-0,324$ \\
$\mathrm{GST}$ & $\mathbf{0 , 8 2 3}$ & $-0,173$ & 0,195 \\
$\mathrm{GSH}$ & $\mathbf{0 , 9 4 0}$ & 0,202 & 0,151 \\
$\mathrm{LPO}$ & $\mathbf{0 , 5 6 5}$ & 0,436 & $\mathbf{0 , 5 9 3}$ \\
$\mathrm{DNA}$ & $-0,354$ & $-0,179$ & $\mathbf{0 , 8 7 9}$ \\
$\mathrm{ChE}$ & $\mathbf{0 , 8 7 1}$ & 0,422 & 0,156 \\
$\mathrm{NRRT}$ & 0,105 & $\mathbf{- 0 , 7 4 1}$ & $-0,382$ \\
$\mathrm{Cd}$ & $-0,475$ & $\mathbf{- 0 , 5 3 5}$ & 0,184 \\
$\mathrm{Hg}$ & $\mathbf{0 , 5 3 2}$ & $\mathbf{0 , 6 2 1}$ & $-0,215$ \\
$\mathrm{~Pb}$ & 0,075 & $\mathbf{0 , 7 1 7}$ & $-0,433$ \\
$\mathrm{As}$ & 0,265 & $\mathbf{- 0 , 8 0 8}$ & $-0,439$ \\
$\mathrm{Cr}$ & 0,239 & $\mathbf{- 0 , 9 5 2}$ & 0,168 \\
$\mathrm{Fe}$ & $\mathbf{0 , 6 7 6}$ & $-0,410$ & $-0,457$ \\
$\mathrm{Se}$ & $\mathbf{0 , 9 1 5}$ & 0,137 & $-0,283$ \\
$\mathrm{Co}$ & $-0,130$ & $\mathbf{0 , 7 8 6}$ & $-0,378$ \\
$\mathrm{Zn}$ & $\mathbf{0 , 5 8 7}$ & $\mathbf{0 , 7 9 9}$ & 0,000 \\
\hline & & & \\
\hline & & &
\end{tabular}

Tabela 39. Scores para cada ponto de coleta, gerados pela PCA a partir dos dados referentes às ostras C. brasiliana coletadas durante a primavera/2016 e o outono/2017.

\begin{tabular}{lccc}
\hline \multirow{2}{*}{$\begin{array}{l}\text { 2016/17 } \\
\text { P16-Can }\end{array}$} & \multicolumn{3}{c}{ Eigenvectors } \\
\cline { 2 - 4 } P16-San & $-0,750$ & $-2,817$ & 2,450 \\
P16-Ber & $-1,577$ & 1,379 & $-0,043$ \\
O17-Can & $-1,929$ & 1,680 & 0,419 \\
O17-San & 3,934 & $-1,815$ & $-0,908$ \\
O17-Ber & 2,480 & 2,983 & 0,433 \\
\hline
\end{tabular}

